Digitized by the Internet Archive in 2008 with funding from Microsoft Corporation 
AN

$(-1,10 \mathrm{en} 5)$ Tiluan 



\section{LET'TERS}

$\Lambda$ N D

\section{LITERARY MEMORIALS}

O F

\section{S A M U E L J. T I L D E N}

EDITED BY

J O IIN BIGELOW, LL.D.

VOL. 1

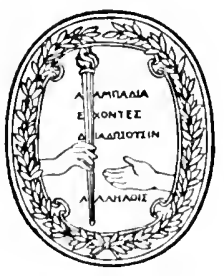

NEW YORK AND I,ONDON

IIARPER \& BROTHERS PUBLISIIERS

1908 


Copyright, IgoS, by HARPBR \& BRothers.
All ri,sits reserved.
Published February, 1908.


Shortly before the dealh of the late Samuel J. Tilden, and in compliance with his wishes, a selection was made by our semior colleague from such of Mr. Tilden's public writings and specches as were then conveniently accessible and seemed then responsive to a popular demand. This selection was edited and published in $18 S 5$.

The forty-second section of the will of Mr. Tilden, who died in the following year, provided as follows:

"I also authorize my said Executors and Trustees to collect and publish in such form as they may deem proper my speeches and public documents, and such other writings and papers as they may think expedient to include with the same, which shall be done under their direction. The expenses there of shall be paid out of my estate. My Trustees and Executors are authorized and empowered to burn and destroy any of my letters, papers or other documents, whether printed or in manuscript, which in their judgment will answer no useful purpose to preserve."

In discharge of the duty imposed on us by this clause of the testator's will, we have selected such portions of a vast correspondence with, or relating to, the testator as give promise of answering a useful purpose; and at our solicitation Mr. Bigelow has undertalien to edit and publish them in a form that shall harmonize with, and be complementary to, the volume of "Specches and Writings of Mrr. Tilden," already in print.

$\left.\begin{array}{l}\text { Join Bigelow, } \\ \text { GeorGie W. Smitil, } \\ \text { L. V. F. RaNdolph. }\end{array}\right\} \begin{aligned} & \text { Executors } \\ & \text { and } \\ & \text { rustees. }\end{aligned}$ 



\section{PREFACE OF THE EDITOR}

AT an early period of his life Samuel J. Tilden seems to have had a sense of its importance not ordinarily felt by youth of his age. This may be accounted for in part by the eiremmstance that while barely out of his teens, both by pen and speech, ho had secured the respectful attention of many of the leading statesmen of his generation. At school he preserved all his composition exereises, and from that time to the close of his life it may well be doubted if he ever wrote a note or document of any kind of which he did not preserve the draft or a eopy. As the events with which he had to deal came to assume, as they naturally did, increasing importance with his years, one or more corrected drafts were made of important papers, most, if not all, of which were carefully preserved.

As what may fitly enongh be termed Mr. Tilden's public life covered more than half a century, during most of which time he was one of the recognized leaders of one of the great parties of the country, the publie will learn without surprise that the accumulations of social, political, and documentary correspondence which fell into the hands of his executors, to be measured by the ton, embraced among its topies almost every important political question by which this nation has been agitated sinee the accession of General Andrew Jackson to the Presidency in 1829.

A eollection of Tilden's Public Wrilings and Speeches was published in 1885 , only a year before his death, but very little of his private correspondence appeared in that publication.

The duty imposed upon his executors of lonking through such a vast collection of papers and selecting such as would be profitable for publication has been a long and a very te- 
dions onc. They indulge the hope, however, that the volumes now submitted will be found to shed rpon the history of our country during the latter half of the last century much light unlikely to be reflected with equal lustre from any other quarter. It will also, they believe, lielp to transmit to posterity a juster sense than as yet generally prevails of the majestic proportions of one of the most gifted statesmen our country has produced.

Tilden may be said to have fleshed his maiden sword in politics as a champion of President Jackson in his war against the recinarter of a United States bank of discount and deposit. He next beeame somewhat more personally conspicuous as a fervent champion of Mrr. Van Buren's substitute for the national bank, now known as the Assistant Treasury.

In 1848 he led the revolt of the Democratic party in New York State against the creation of five slave States, with their ten slave-holding Senators, out of the Territory of Texas. Among the immediate results of this revolt were the defeat of General Cass, the Democratic candidate for President, and the development of a Free-soil party, which later took the name of the Republican, nominated and elected Abraham Lincoln to the Presidency-synehronously with whieh, and for the first time in the nation's history, the decennial census of 1860 disclosed the fact that the political supremacy of the nation had been transferred to the non-slaveholding States.

Though averse to resisting the secession of the slave States by flagrant war, Tilden did his best and much during the war to prevent an irreconcilable alienation of the people of the two sections, while at the same time building up for himself a reputation in his profession scarcely second to that of any other in the country; and by it, before he had reached the fiftieth year of his age, a fortune which made him no longer dependent upon it for his livelihood.

The first public use he made of this independence was to retrieve the fortunes of the Demoeratic party by delivering the eity of New York from a numicipal combination which was threatening it with bankruptcy. 
Of 'Tilden's many arhievements as a public servant, it may well be doubted if there was any for which he deserves so much honor as for his part in the overthrow of this pillaging combination, fanniliarly known as the Tweed Ring, nor any for which it secms so entirely impossible to have then provided another equally competent leader who conld and would have given the time, incurred the expense, and assunned the risks that Mr. Tilden did when, with no personal advantage in view, he boldly consecrated several of what might have been the most lucrative years of his professional life to this desperate battle with intrenched municipal villany.

The people of the State were not slow to realize that a man with the courage, power, and resources exhibited by Mr. Tilden in this memorable confliet was precisely the kind of man needed by them for Governor; and while yet wearied with the fatigue and eovered with the dust of this munieipal struggle, he was eonstrained by his admirers to enter the lists as a candidate against General Dix, the Republican eandidate for that offiee. The result was a change of about 100,000 votes from the number by which Governor Jix had been elected two years before, and Tilden's triumpluant election to his place.

Without doffing lis armor, and eren before his investiture with his new robes of office, he instituted an elaborate investigation of the eanals of the State; so that he had been lut a few weeks in oflice before he wis engaged with numerically a far more formidable foe than the one over, which he had just trimmphed, but one for which his official position happily equipped lim with far isuperior resources. His trimuph over the Canal Ring of the State was eonsequently so slort, quick, and decisive as to give him a national reputation, and to make him, long before his term of office at Albany expired, the incvitable candidate of his party to suceed General Grant for the Presideney. Me was unanimously nominated by the Demoeratic National Convention, licld at St. Louis in 1876, on the second ballot, and was elected by a popular majority of over 250,000. He was then destined to receive a distinetion never shared by any vii 
President of the United States, of being an elect of the people for that office, which, by the operation of a tribunal unknown to the Constitution, was given to another.

For the remaining ten years of his life Tilden's health prevented his being wholly a candidate or wholly not a candidate, so reluctant were his numerous friends to give up all hope of such a restoration of health as would enable him to resume once more the leadership of his party. In this they were disappointed.

Thus for more than half a century Mr. Tilden was a shaper and a maker of American history. What kind of history and by what means it was made these volumes are expected to render more clear to the world, and his fame perhaps more enduring.

Mr. Tilden's life, like that of Israel's second king, was, as we have seen, a life of almost constant warfare, and of course he was always more or less liable to be viewed by partisan eyes and judged with only partial justice. None of us can judge himself quite correctly until he can look back upon his conduct after a considerable lapse of years. So we only see a public man as he is entitled to be seen, as Moses was permitted to see his Lord: after $\mathrm{He}$ had passed. It is to be hoped that sufficient time has elapsed since Tilden was taken from us to enable us to see by the reflection of his life in this correspondence how lofty was the plane of his entire public life, and how correctly he judged his qualifications for a successful political career when he said that his party standards were too high for the multitude. They were too high, unquestionably, for what is commonly understood as success in politics. It would have been easy for him-as these pages will show-to have been President had his ethical standards been nearer the average of those of the parties of his time.

Without presuming to institute any invidious comparisons, I have no hesitation in expressing my conviction that neither in the writings, speeches, or literary remains of any President of the United States thus far will be found more suggestions profitable for teaching, for reproof, for correction, and for the instruction of any American who 


\section{PREFACE OF THE EDITOR}

aspires to be a maker of a nation's laws or an administrator of them, than will be found in Mr. Tilden's Writings, Speeches, and Correspondence.

With the permission of Messrs. Houghton \& Mifflin, I have prefixed to these volumes an "Appreciation" of Mr. Tilden by the late James Coolidge Carter, which originally appeared in the Atlantic Monthly of October, 1S92. Mr. Carter's eminenee at the American bar and formm, and his relations, both personal and professional, with Mr. Tilden, give value to his judgment of his deceased friend which, both for the honor of himself and of Mr. Tilden, is entitled to all the prominence that can be given to it in these volumes. 


\section{.}<smiles>C1CCC1</smiles> 


\section{MR. TILDEN}

\section{AN APPRECIATION, BY JAMES C. CARTER}

Mr aequaintance with Governor Tilden began a few years before the War of the Rebellion, and my first impressions were not favorable to him. Completely dominated by the combined and swelling impulse of patriotism, passion, and aspiration under which the Republican party was then gathering its mighty hosts, I was in no condition to tolerate anything in the nature of opposition to the movement, or even to appreciate the reasons upon which any such opposition might be founded.

It was not until the war was over, when the passions had subsided, when it became necessary to cultivate the arts of peace and to restore the waste and ruin which war had wrought, that I was inclined to extend any hospitality to the qualities for which he was most distinguished, or to lend any ear to his teachings. Drawn from year to year into a nearer acquaintance with him, and having oceasion, when he eame to fill stations of influence and power, to observe the ready sagacity and easy skill with which he coneeived and carried through important measures for the redress of errors and frands in public administration, I became more and more impressed with his prodigious superiority to other men.

What he would have been able to accomplish had he been permitted to assume the functions of the great office to which the majority of his countrymen believed him to have been clected is matter of idle conjecture only; but the list of his achievements during the few years in which, upon a narrower theatre, he acted a pullic part can hardly be matehed. Onitting from view the splendid contributions made by him 
from time to time, prior to 1871 , by papers and speeches upon the principles of politics and the methods of governmental administration, and taking note only of the practical measures in the conception and execution of which he was the leader during the five short years in which, either as a private citizen or as public officer, he was actually engaged in the public service, we can distinctly impute to him the following results: In 1871 he seized the opportunity; suggested by the disclosure and publication of the prodigious sums drawn from the New York city treasury by way of pretended payment of municipal debts, to endeavor to fasten upon the principal city officials the crime, universally suspected, but of which there was no proof, of having corruptly embezzled to an enormous extent the moneys of the city. By a long and patient tracing of a multitude of accounts in different banks, he reached a series of results which, when compared, not only disclosed but conclusively demonstrated, by competent legal evidence, the whole scheme of fraud, the officials engaged in it, and the amounts received by each. Although a strict party man and chairman of the Democratic State Committee, yet, finding that the Democratic organization of the city of New York could not be wrested from the control of the official delinquents, he organized and led the popular movement which effected their overthrow. He accepted, at the same time, a nomination for the legislature, was elected, and extorted from a reluctant majority the impeachment of the corrupt judges who had disgraced the judicial ermine. In 1874, when the craze for fiat money had become prevalent throughout a great part of the country, and more threatening to the public prosperity than the free-silver delusion has at any time been, he drew from the Democratic State Convention of New York the first condemnation which it had received from either of the national parties. Elected in that year as Governor of the State, he conceived an extensive series of reforms in administration, drew the necessary legislative bills, secured their adoption, and carried them into effect. These plans contemplated, by the adoption of new methods and various economies, extensive reductions in the public expenditures, 


\section{MR. TILDEN: AN AP'PRECIATION}

the institution of suits for the punishment of frauds of public officers, and the recovery of moneys embezzled by them. They had very large practical results.

Nor was he less efficient in bafling mischievous sehemes. The Democratic organization of 'Tammany Hall, reorganized, after the overthrow of Tweed, under the leadership of John Kelly, an able and not dishonest partisan chief, demanded from the Democratic majority in the legislature the passage of laws designed to secure to that organization a more complete control of the municipal patronage. Governor Tilden refused to lend his countenance to this policy, and the imperious leader undertook to foree him into acquiescence by forming a combination in the legislature with the numerous adherents and stipendiaries of what was known as the Canal Ring. That coterie of men, powerful in both parties, had already scented the peril to their practices threatened by the Governor's reformatory plans, and were only too willing to join in a warfare against him. He suddenly found himself in danger of being deserted by a majority of his own party. 'The Democratic Speaker of the Assembly took the floor, and arraigned him as unfaitlful to the Democracy of the State. He had long before seen the possibility of this combination against him, and had sought by the practice of all the conciliatory arts, of which he was a thorough master, to prevent it. When it came, he was not daunted by it, but boldly went behind his enemies to the constitueneies which they were betraying. They soon found that they were dealing with an adversary who possessed resourees which they had not taken into account. Most of them abandoned their opposition. The rest were severely dealt with by their eonstituents.

Never were the possibilities for good of a great office like that of Governor of New York so happily developed and displayed. In the course of an administration of two years, an enormous reduction in taxation was effeeted; the administrative system in every department was improved; the lobby was almost dispersed; and at the same time the Governor, in his communications with the public through his annual messages, his veto messages, and speeches 
upon official and other public occasions, was furnishing to the people of the State, and indeed of the whole country, a nearly complete exposition, theoretical and practical, of the whole work of public administration. I have never read a state paper which equals his second annual message in the power and ease with which it treats of the principles upon which government should be conducted, or in the order and perspicuity with which it arranges and sets forth the details of public business. In this paper he considers at much length the then depressed condition of business, its causes, and the proper remedies. It may be thought-was thought at the time by some-that this was going beyond the domain of state affairs in order to make an ambitious display of knowledge upon the larger concerns of the nation; but it would be well if every man possessing such knowledge as is here exhibited, and such a capacity for communicating it, would embrace all opportunities to display it. Governor Tilden, however, had a special motive in placing his views before the country at that time. He saw the false policy of indefinite issues of government legal-tender currency everywhere taking hold of the public mind, and that, unless speedily corrected, it would acquire a force to which the timidity of political leaders would submit. He had already induced a convention of the Democratic party in New York to take ground against it. He wished to draw forth a similar declaration from the Democracy of the nation, at its next convention for the nomination of a President. He succeeded; and to his influence, probably, more than to that of any other man, we owe the downfall of the paper-money delusion.

An attempt to analyze the rare combination of talents and faculties which enabled him to accomplish so much in a period so brief may not be uninteresting. His original intellectual endowments were of the highest order. They. were not of that character which, while leaving their possessor satisfied with some hasty and superficial conclusions that at the moment seem true, enable him to impress them upon others by fervid and moving language. These are the intellectual traits most frequently exhibited by the ablest 


\section{MR. TILDEN: AN APPRECLATION}

men whom our public life brings into notice; but they do not make up the scientific mind which Governor 'Tilden's preeminently was. At the beginning of his intellectual manhood lie clearly pereeived that the whole moral world was as rigidly as the physical world subject to an order, an arrangement, a law; and that all policies, whether in government, in finance, or in business, not founded upon a recognition of this truth would result in confusion and mischicf. Naturally attracted to the study of the pullic economy of States, his first aim was to eliscover the laws governing every part of that extensive domain. Whether the theme was expenditure, taxation, private or public justice, internal improvements, or any form of public administration, he would make no utterance until his brooding mind had reached what he conceived to be the underlying truth; and the same trait was manifest in him where the purpose was not to refute or establish a general policy, but to ascertain, in a particular case, the truth upon a disputed question of fact.

This was well illustrated in his defence, in 1856, of the title of Azariah C. Flagg to the office of comptroller of the city of New York, against the claim of John S. Giles. Flagg had been declared elected by the Board of County Canvassers. He was a man of resolute integrity, had held the office before this election, and, by his obstinate defence of the city treasury against unjust and fraudulent claims, had drawn upon himself the hatred of the municipal plunderers, and earned from them the title of "Old Skinflint." His enemies had made a combined and desperate effort to defeat his re-election, and, having failed by a few rotes only, they determined, upon the pretenee of an erroneons return, to make an attempt to oust him from his office by a judicial procecding and install Giles in his place. For this purpose they fixed upon the vote of the first district of the Nineteenth Ward, the majority of the election officers of which were bitter enemies of Flagg. Their pretence was that the return of the district election officers giving : 16 votes for Flagg and 156 for Giles was a clerical error, by which Giles' vote was awarded to Flagg and Flagg's rote to Giles. 
Three of the election officers who signed and filed this return were sworn as witnesses for Giles, and positively testified that the vote as actually comted was just the reverse of the return; that Giles had 316 votes, and Flagg 186. The original tally-list of the regular tickets, which would have shown the truth, had been conveniently lost, but these witnesses produced what they swore was the original tallylist of the split tickets, and upon which was a pretended transfer of the votes on regular tickets, which they swore was correct, and this fully supported their statements. Other witnesses on the same side testified that they were present at the close of the counting on the day of the election, and heard the result proclaimed, and that it gave 316 to Giles and only 186 to Flagg. This formidable case could be overthrown only by showing that these witnesses were perjurers, and this pretended split tally-list a forgery. Tilden had no doubt that this was the fact, but he had no direct evidence to prove it. He was a determined enemy of these base conspirators and a close friend and ardent admirer of Flagg, and he was resolved that the fraudulent scheme should not succeed. Acting upon the assumption that a lie has no place in the regular order of nature, but is something violently thrust into that order and will not fit the surrounding and attendant facts, he laboriously endeavored to bring into light, so far as possible, all those surrounding and attending facts. It so happened that this election was a contest between numerous factions, and that there were seven regular tickets voted; that is, tickets having uniformly the same names and for the same offices; and there were twelve candidates for the various city offices on each ticket. There were also many split tickets, created by erasure of one or more names from a regular ticket, or otherwise. Here was fruitful material for the exercise of Tilden's powers of investigation. He demonstrated, and with mathematical certainty, by an analysis and comparison of the actual returns of votes for all the candidates on these tickets, that the pretence of Giles was a pure fabrication. At the close of his argument he threw his demonstration into a dramatic form, which created such an impression that, as Mr. Charles xvi 


\section{MR. TILDEN: AN APPRECIATION}

O'Connor, who was associated with Mr. Tilden, once told me, the case of the plaintiff Giles was utterly defeated before the defendant had called a witness. It was, of course, difficult for the jurors to carry in their minds the numerous figures which made up the demonstration. Something was needed to impress upon them the result. For this Tilden pitched upon the lost original tally-sheet of the regular vote. It was upon the amount of Flagg's regular vote that the whole controversy turned. If the contents of that lost tally could be shown, all doubt would be dispelled. Said he, "I propose now, gentlemen, to submit this case to a process as certain as a geometrical demonstration. I propose to evoke from the grave that lost tally; to reproduce it here, to confront and confound these witnesses who have been upon the stand swearing to what is not true. It is an honest ghost. It will disturb no true man." And he did it triumphantly. IIanding to the jurors sheets containing copies of the regular tickets, and selecting a name which was found on only one of these tickets, that of Samuel Allen for street commissioner, he called off from the actual return to the Board of County Canvassers, and the jurors set down Allen's vote, which was 215. It neeessarily followed that every other name on that ticket must have received the same number, or the ticket would not be regular. Proceeding in the same way with all the names on all the tickets, and then deducting the regular vote from the whole vote as shown by the actual return, and thus obtaining the split rotes for each candidate, and comparing these results, except as to Flagg and Giles, with the tally-sheet of the splits which had been produced by the witnesses for Giles, and which was presumably correct, exeept in respect to the vote for Flagg and Giles, he slowly, step by step, re-created an original tally of the regular ticket, which, when increased by the split votes shown on the split tally-list, corresponded in every particular with the actual return to the county canvassers except as to three unimportant names, and as to these it was manifest that the actual return was erroneous. Each juror found, at the close of the calling, that he held in his hands what he could not but believe was an absolutely accurate count of the votes in xvii 
the first distriet of the Nineteenth Ward for all the eandidates roted upon, for whatever office, at the election under investigation. The hideous monstrosity of the figures assigned to Flagg and Giles in the split tally-list became so palpable that none could doubt. It is needless to add that when the ease was finally submitted to the jury they immediately returned with a verdict for "Old Skinflint."

He employed a similar method in the case of what was called the Six Million Audit frand of Tweed and his accomplices. That the payment of this enormous sum was a gigantic frand no one could doubt; but there was no proof showing how much of the payments was in excess of what was due to the claimants, or among whom the exeess was divided, and how much to one and how much to another. Mr. Tilden unlocked this mystery. He went to the banks in which the eonspirators kept their accounts, and by a patient decomposition of the eredits into the original items, as shown by the deposit tickets, evolved the plunderer's' rule of division. Applying this rule to any one of the hundreds of paid city warrants embraced in this series of frauds, and without going beyond the face of the warrant, it could be determined how much each of the conspirators received; and the determination would be verified by finding, upon examining the bank accounts and deposit tickets of the same parties, that they had reeeived on the day of the payment of the warrants the same sums which, according to the rule applied, they ought to have received. It vexed Mr. Tilden very mueh that the shares of the conspirators, as thus computed, did not correspond with perfect exactitude to the amounts deposited to their eredit. The difference, being trifling in amount, hardly affeeted the conelusiveness of the demonstration; but it showed that there was some element in the rule of division which he had not discovered. The missing link was subsequently found, and then the conformity between the computed and the actual shares was in every instance exact to a penny. This division and conformity, appearing upon the face of the accounts themselves, proved with alsolute certainty the conspiracy to defraud, the amounts of the embezzlements, and the prexviii 
cise shares received by each. Had Mr. Tilden been present at the meetings of the conspirators and witnessed their division of the spoils, he could not have given evidence so conelusive of the fraud as that which he thus drew from written memoranda which the conspirators had thoughtlessly allowed to be made.

It was indeed wonderful to observe how a man who could study these dry details with such patience, and even with pleasure, could pass at onee into the fields of political science and compel a wholly different class of facts to yield to him the lofticst generalizations. But in truth the process was the same in both instances. It was the original investigation of facts for the purpose of framing a just theory. It is a common practice, even with able men, to disparage the conclusions founded upon the employment of the reasoning powers as heing mere theory; as if their own conclusions, so far as they have any value, were reached in any other way. These are the eriticisms of men who are too indolent to engage in the work of patient investigation, or not sufficiently instructed in the methods by which it should be pursued. Undoubtedly there are many minds that undertake the task of evolving the laws underlying some subjeet matter and reach conelusions which are confidently helieved and asserted to be true, but that turn out when adopted in practice to be erroneous. It is in this way that the results of investigation and reasoning are bronght into discredit. But the fanlt in such cases is not that the conelusions aro those of mere theory, but of erroneous theory. The reasoner lacks the patience, or the skill, to embraee in his investigation all the material facts, and to exclude all others. These are, indeed, the rarest of qualities. They aro possessed in an eminent degree by a few men only in each generation, and the value of such men to socicty is inestimable. Gorcrnor 'Tilden's pre-eminence was especially manifest here. IIis educated intelligence was able to pronounce, as if by instinet, whether the eonchusion he had reached was suffieiently eertain to be made the basis of action, or was so cneumbered with doubt as to eall for further serutiny into the facts. He knew how-to use his own happy phrase$\operatorname{xix}$ 
"to limit theory by practice and enlighten practice by theory."

The mere pursuit of truth, the pleasure which eomes from the actual exercise of superior powers, the sense of satisfaction which arises from the overcoming of difficulties, would have been a sufficient reward and stimulus to a mind like his; but this was not his principal motive. His chief aim was to convince others; and he knew that this could be done only by the effective use of language. He recognized the importance of the art of rhetoric, and labored upon the composition of his papers with the same care which the purely literary man employs; not for the purpose of making up a piece of what is called fine writing, but to engage and hold the attention by imparting life and interest to his treatment, and, by an easy and natural development of his subject, to carry the mind gratefully along towards his conclusions. It would be hard to find better examples of the way in which subjects apt to be regarded as dull may be made lively and interesting, and yet without departing in the slightest degree from a rigid and logical development, than are found, in his report, while a member of the legislature of New York, upon the causes of the anti-rent disorders and the proper remedy for them; or his speech in the constitutional convention of that State in 1867, unfolding the true policy to be pursued in relation to the canals; or his second anmual message when Governor in 1876. I find, on the page at which I open a volume of his speeches and writings, the following sentence, which well illustrates the ease and power with which he could elothe weighty truths in their appropriate language: "Generations, like individuals, do not completely understand inherited wisdom until they have reproduced it in their own experience."

These high intellectual traits would have made him a man of mark had he been a philosophical recluse holding himself aloof from the busy activities of life; but the extraordinary thing was that he was at all times emphatically a man of action. Whether engaged in the eonduct of some great lawsuit or of some important business enterprise, or managing a political campaign, he was equally at home. 


\section{MR. TILIEN: AN APPRECIATION}

The sehemes of small party ehicftains and the power of local bosses gave way before his masterful leadership. IIe dicl not despise the aid of partisan machinery or of oflicial patronage; but he fully perecived that the seope and influence of these instrumentalities were narrow, and that, muless held rigidly secondary and subordinate, they would obstruet, rather than aid, the march of a political party. Profoundly convineed of the truth of the political creed which he arowed, he engaged in political warfare only to secure its permanent establishment. Any victory won by shifty expedients he knew would be but temporary, and would not fail to retard a lasting success. At the same time he recognized the fact that no main purpose of a political party could ever be carried except by the permanent union of men differing from each other upon a multitude of minor points, and exhibiting every grade of culture, character, and conduet. Compromise and coneession be recognized as the daily duties of the statesman. He had little regard for those impracticable natures which refuse to join any party because they find something to object to in all parties. He was the last man to yield to self-eonceit and obstinacy the titles of conseience and wisdom. Snch men, he once declared, forget "that without concession there can be no common action for a common object, and that without the capability of such action a man is fit, not for socicty, not even for a state of nature, but only for absolute solitude." I wonder that the mugwump - haters have not borrowed his description of some non-partisans of his day: "I know there is a class of no-party men who vindicate their claim to that character by doing injustice to all, even without the excuse of bias."

But how far should you carry the spirit of compromise and encession-liow far tolerate what you believe to be error in order to obtain an over-halancing good? 'This is the puzzle of statesmen, and indeed of every man, so far as he undertakes any part, even though only as a private citizen, in public eoncerns. There are two ways of dealing with it. One is to shirk it ly an indolent albandonment of the important offices of social and public life. The otler' is to meet it with the best solution we ean find. Tilden had little re- 
gard for the first of these methods. IIe accepted the sceond; and with his miatehless ability for drawing a line up to which we must, but beyond which we must not go, he would have had little excuse for the other choice. There were several oceasions when he felt obliged to draw this line and rigidly observe it, although the result might be immediately disastrous to the party to which he was attached and to his own personal ambitions. His opposition, in 1871, to Tammany Hall, already noticed, is an instance. Occupying, as he then did, the important post of chairman of the Democratic State Central Committee, he could not step out of the local organization in the metropolis and make war upon its leaders without seeming disloyalty to his party, nor without endangering its success in the next State election. But he determined, against combined solicitations and threats, to take this conrse, and the result showed the wisdom of his choice, even as a measure of party policy. And again, when the irredeemable paper-money delusion had to a far greater degree than the free silver coinage craze gained possession of the popular mind throughout the West and South, and in the view of many ardent politicians promised a victory to the Democratic party if that party would extend some favor to it, he compelled from the national convention of the party a repudiation of the heresy. No temporary advantage which his party might gain would in his view be worth acceptance, if purchased at the price of such a sacrifice of fundamental principle.

It is not to be wondered at that with his profound knowledge of the causes by which human affairs were controlled, combined with such eapacities for skilful action, he should have accumulated a large fortune. Aside from what he received for professional services, his large gains were, I imagine, rather easily acquired. Among the mischiefs of an unstable curreney is the facility with which men who have the power of dealing skilfully with exceptional conditions may amass large fortunes. Few men understood such things better than Mr. Tilden. Me had striven to prevent, as well as a man in opposition could, the issue, during the war, of an irredeemable government currency; but I rememxxii 


\section{MR. TILDEN: AN APPRECIATION}

ber his saying to me after the policy was adopted, in substance: "Now is the time to make yourself rich. Buy all that you can pay for, or run in debt for. Every day it will be easier and easier for you to pay, and your property will correspondingly rise in value, or rather in price." And at the close of the war he advised the opposite course. I do not know, but I have little doubt that he acted extensively on this poliey. If there were a question as to the propriety of such action, he certainly was excusable. Had his counsels been regarded, no such measure would have been adopted.

The malice of political opponents was wont to ascribe his success in moncy-getting to schemes for obtaining interests in the property of insolvent railway companies at less than their value. They stigmatized him as a "railroad-wrecker." Never was there less foundation for a charge. He was a railroad-preserver. His skill in the management of difficult and complicated affairs, combined with his profound knowledge of the fundamental principles of equity, made his services invaluable to parties interested in the property and securities of railroad companies which by bad management, or in consequence of over-sanguine expectations, had fallen into difficulties. His eapacious mind was just fitted for the survey of such situations. He was among the first, if not the first, to perceive that a ruthless attempt to forcelose a first mortgage and thus to erush out all subordinate liens and interests was ill-suited to such cases; that the just and true method was to ascertain the real eapacities of the business, and to reorganize the enterprise upon a scheme which would indulge the hope of saving to the junior securities a large part of their supposed original value. More than one of the great railroads of the country have, at his skilful touch, risen from alsolute bankruptey into prosperity, and repaid all or the larger part of the original investment.

With all his capacity for making sober estimates, and escaping the illusions by which many minds are carried away, he was yet an enthusiast, especially in respect to the plans and enterprises which were the offspring of his own fruitful brain. This eame partly from personal vanity, of which he had a plentiful supply, and partly from the exxxiii 
hilaration which attends the exercise of high intellectual powers and rewards the conquest of difficulties. I remember a display of this tendency which greatly impressed me.

In the performance of a professional service for him while he was Governor, in connection with a lawsuit to which he was a party, it became necessary that I should tarry several days at his house in Albany in order to secure his attention during the intervals between his official duties. It was while the St. Louis Convention was in session at which he was nominated for the Presidency. One would suppose that under such circumstances he could have given his mind to little else than the business in which his personal fortunes were so deeply concerned. But he could not have devoted himself more ardently to recalling and arranging the facts of the complicated transactions out of which this lawsuit grew than he did on the very day when he was nominated. Late in the afternoon of that day, after protracted work, he took me upon a long drive with him. In the course of it he did not even allude to the convention, or its doings, although a flight of telegrams had been coming to him. His conversation, animated and incessant, was upon false policies in government, the mischiefs and burdens of over-expenditure, the true principles of taxation, the errors of protective tariffs, etc. One could see that the mere matter of holding the Presidential office was little to him; but that the chance of laying his reforming hand upon the multitude of abuses with which, as he supposed, the whole administration of the general government was infested aroused his enthusiasm, as the prospect of a season of sport would that of a boy. Becoming animated with his theme, eloquent and intense in his language, he failed in attention to the high-spirited horse he was driving, and I was in constant fear of a catastrophe. Indeed, on a similar drive the succeeding day we met with one from the same cause. The injury was inflicted instead of received, and cost the Governor several thousand dollars by way of damages. When, on our return, on the day first mentioned, we were near home, I observed to him that he would perhaps find at the house a telegram announcing his nomination. "No," said he, unconcernedly, "not until xxiv 
about half-past nine." It came not many moments from that time. Impressed upon this oceasion with his profound and extensive knowledge of everything relating to the seienee of government, and thinking his views not substantially at variance with those held by leading Republicans-for at that time the Republican party had not become committed to its present dogmas on the subject of protective tariffs-I ventured to express to him the surprise I felt that he had not allied himself with that party; saying that it seemed to me that, considering the greatly superior number of men of education and public spirit to be found in its ranks, he could much more easily procure a general aceeptance of his opinions by acting in alliance with them. He answered that he thought that I was mistaken; that, while it was true that a large majority of the men of eulture, wealth, and force were to be found in the Republican party, the trouble was that, to use his language, "it was a party of self-seekers." He explained that he did not mean this in any offensive sense; that what he meant was that the controlling men of that party were men of large pecuniary interests, seeking to build up fortunes and families; that these personal interests were so large as necessarily to engross their thoughts and control their opinions, leading them to use their powerful influenee so as to shape the legislation of the country in a form which would favor those interests; that it was difficult to lead such men along the pathway of those fundamental principles of democratic government by which alone equal justice could be done to the masses of men; that the Democratic party held within its ranks a far less number of men of this deseription-not enough to control its action-and consequently the opinions of its great masses could be more easily shaped and molded by the mere foree of ideas; that this was the distinetion between the former Democratic and Whig parties, and that the Republican party would, as the patriotic inspirations canght from the opposition to slavery and the defence of the Union died away, become the mere suceessor to the spirit and poliey of the Whig party.

"These observations, as applied to the two present $\mathrm{xxV}$ 
parties of the country, would not, probably, be accepted without dissent; but they intimate a most important truth. This is that when a man comes to be the possessor of large property interests, these will, whatever may be his character, control his opinions in relation to any question affecting them. The great railroad interests of the country are conducted by men, I suppose, of as honorable character as can be found in any walk of life; but they will not, in the face of threatened disaster, keep the agreements they make with each other. They do not hesitate, when these interests are threatened by adverse legislation, to defend them by secret arts and practices-kept secret because they could not be avowed without a blush. Mr. Jay Gould, in some testimony drawn from him by a legislative committee, expressed the truth by saying that he was "sometimes a Democrat and sometimes a Republican, but always an Erie man." It must be admitted that the occasions are often fearfully trying. They sometimes impose a test which human nature is ill-fitted to bear. The individual who is subjected to them is called upon to defend, not only his own property, but that of others. A man may surrender his own interests, but what account is he to give of himself when he surrenders interests which have been intrusted to him for defence?

I cannot help thinking that Governor Tilden possessed, on the whole, greater capabilities for usefulness in public life than any other man of his generation. I cannot find elsewhere such a union of the ability to discover true governmental policies with the firm and undeviating purpose to pursue them. This is not the universal estimate of him. A certain measure of distrust seems to have accompanied the general admiration of his talents. For this there never was any just foundation. I do not think any public man of his time was more faithful to his conceptions of truth. No impartial man could now well doubt this after going over the record of his services and reading his speeches and public papers. Indeed, it is hardly possible that so ardent a searcher after scientific truth could be otherwise than faithful to it. We can scarcely imagine Socrates and Newxxvi 


\section{MR. TILDEN: AN APPRECIATION}

ton to have been dishonest men. That Lord Bacon fell excites our wonder. And yet there must always be some ground for any widely extended impression. I think that in this instance the cause is manifest. His pre-eminence was in the intellectual rather than in the emotional powers. In order to achieve his purposes he preferred to appeal to the intellect rather than to the heart. Plain, blunt honesty is universally perceived and understood, and is admired and eonfided in, even when it blunders. But common men have so often been deceived by the sharp practices of those who are a little brighter than themselves, that they are apt to distrust intellectual superiority, and half suspect it to be a speeies of cunning. The malice of personal and party hostility, working upon this natural tendency, has found an easy acceptance of its calumnies.

But, beside this, Governor Tilden was a practical leader in affairs, both of business and politics; and although he was all openness and eandor in his public discussions, yet in his methods of action he eould not, any more than other men, dispense with secresy and reserve; and as he was apt to excel others in whatever methods he adopted, he perhaps excelled them in secretireness as well. A good share of another quality which does not tend to secure admiration for the possessor fell to Mr. Tilden. It was not unnatural that a man so conseious of superior powers should be somewhat vain. Men do not like to have "I told you so" flung into their ears at every turn in the course of events, and Mr. Tilden had a habit of doing this.

But he was by no means wanting in the sense of moral earnestness, and he had a just perception of the occasions demanding the exereise of that faculty. He was well aware that frand and corruption could not be suceessfully combated with the weapons of reason, and that they did not deserve to be reasoned with. When he found himself confronted by the powerful Canal Ring, which lad fattened for a generation upon fraudulent contracts for repairs and pretended improvements to the canals, a ring which had founded wealthy and influential families, and had its stipendiaries among the able lawyers of the State, he per- 


\section{LETTERS AND MEMORIALS OF SAMUEL J. TILDEN}

ceived that it was a warfare in which no quarter could be given, and which could not be carried on by the weapons of facts and figures alone. He courageously determined to invade, single-handed, the strongholds of his enemies, and to arouse against them the moral indignation of the people. Using a vacation from pressing official duties, he made a series of speeches in a tour along the line of the canals from Buffalo to Albany. Flinging aside his customary temperance and moderation, he denounced his adversariesmen of wealth and the highest social standing-as criminals, and summoned the people to stand by his side in an effort to enforce against them the criminal law. Speaking at Syracuse, in the midst of the men he was condemning, he said: "Here, under your own eyes and your own observation, these transactions have been carried on in open day, by a combination that has sought to rule the State. ... I was called upon this morning to speak some words of encouragement and hope to four hundred little boys in the Western House of Refuge. During all my journey I have been frequently followed by persons asking for their friends and those in whom they were interested a pardon from the penitentiaries and State-prisons. I have been compelled to look into such cases to see who are the inmates of these institutions, and of what they have been accused, and to ascertain what it is that constitutes the wrong to society of which they have been convicted. When I compare their offences, in their nature, temptations, and circumstances, with the crimes of great public delinquents who claim to stand among your best society, and are confessedly prominent among their fellow-citizens-crimes repeated and continued year after year-I am appalled at the inequality of human justice." He made by this series of addresses a profound impression upon the public mind.

He was cautious not to be imposed upon by those who wished his official aid or influence, and commonly subjected them to a searching cross-examination, but a case of real distress quickly moved him. I remember an instance which occurred during my sojourn, already mentioned, at the Governor's mansion in Albany. We were at work together xxviii 


\section{MIR. TILDEN: AN APPRECIATION}

rather late one evening, when he was told that a little girl wished to see him. She was wretehelly clad, and seened to be in great nisery. Moments were then quite precious to him, but he dropped everything and spent half an hour with her. When he returned to the library where we were at work he told me her tale. It was that she was the oldest of several children; that her father was a drumkard and cruel to her mother, who also sometimes got intoxicatedthough, as the girl said, only when her father abused her -and who had, the day before, although having a nursing infant only a few weeks old, been sent to prison for ten days for drunkenness; that the little girl had been vainly endearoring to take care of the infant and the rest of the family, but had given up in despair. The Governor seemed a good deal moved at this separation of mother and infant, and spoke with indignation of the manner in which the eriminal law was administered in the lower courts by incompetent magistrates. He immediately despatched a secretary to the executive chamber for a sealed pardon in blank, filled it up and signed it, and sent the same secretary with the girl to the prison, with instructions to see that the woman was released and taken to her home that very night. I asked him whether this was not rather hasty and ineonsiderate action, adding that possibly the magistrate, if consulted, might give a different statement of the case. He answered: "No, and I wouldn't believe lim if he did. Don't I know that the little girl told me the truth ?"

In assigning to Governor Tilden eapacities for public usefulness superior to those of other men of his generation, one qualification should perhaps be made. IIe could not have led, or rather guided, as Lincoln did, the storm of patriotic passion which the Sonthem insurrection aroused. There are resistless currents in human affairs which disdain the feel)le control of nere reason, and insist upon working their way loy force alone. War is a conflict of the passions, and, when it becomes necessary or preferable to peace, those passions should be inflamed rather than checked.

But the superior wisdom of Governor Tilden was equally xxix 
manifest in this great crisis, although, perhaps, incapable of dealing with it. Naturally anti-slavery, he had encouraged the first tendencies towards the assertion of the Freesoil sentiment of the North by joining in the revolt of the Northern Democrats against the nominees of the Democratic convention in 1848, and supporting the candidates nominated at the Barnburners' convention at Utica. But when he saw this morement developing into the formation of a permanent political organization under the name of the Republican party, with the avowed object of preventing by national legislation any further extension of slavery, he paused and receded.

The argument of the supporters of the new movement was that Congress had the power, not, indeed, to interfere with slavery in the States, but to prevent its establishment in the Territories; and that they were but exercising their constitutional rights in forming a party for the purpose of securing such legislation. Tilden could not deny the mere claim of constitutional right; but this, with him, was but a small part of the question. What would be the consequence of a suceessful assertion of that right? Could it be reasonably supposed that the Southern States would view it otherwise than as an attack upon what they deemed to be a vital interest? Would not its necessary effect be to force unanimity among them in opposition to the policy? Was the supposition that there was any considerable Free-soil sentiment in the South which would array itself on the side of the government anything but a dream? Should we not have two strictly sectional parties arrayed upon the question of preserving or destroying an institution which one of them, not unnaturally, regarded as essential to selfexistence? These, in his view, were questions which must be first solved before such a movement could be encouraged. His solution led him to the conclusion that war would be the necessary result of such action; and this involved the further inquiry whether the object in view would be gained by a civil war, or, if gained, would be worth the terrible cost. Appalled by the uncertainties and terrors of such a conflict, he took refuge, as Mr. Webster had before him, in 
the belief that the natural forces in operation would of themselves accomplish all that conld be gained by the policy of restriction. In a letter to William Kent in 1560 , before the election of Lincoln, he stated his conchusions and the reasoning which led to them with his characteristie moderation, but with masterly force. His main conclusion was that if the Republican party should be successful, the national government in the Southern States would cease to be selfgovernment, and become a govermment by one people over another distinct people-a thing impossible with our race, exeept as a consequence of snceessful war, and even then incompatible with our democratic institntions. He said:

"I assert that a controversy between powerful communities, organized into governments, of a nature like that which now divides the North and South, can be settled only by convention or by war. I affirm this upon the universal principles of human nature, and the collective experience of all mankind." And again: " $\Lambda$ condition of parties in which the federative govermment shall be carried on by a party having no affiliations in the Southern States is impossible to continue. Such a government would be out of all relation to those States. It would have neither the nerves of sensation which convey intelligence to the intellect of the body politic, nor the ligaments and muscles which hold its parts together and move them in harmony. It would be in substance the govermment of one people by another people. That system will not do with our lace."

This reasoning was founded upon the facts of human nature, the philosophy of government, and the teachings of experience. Its truth is more manifest now than when it was uttered. Who of the great Free-soil leaders would have had the hardihood to persist in their comrse if they conld have foreseen the consequences so clearly? Greeley, terrified by the horrible spectacle of war, was driven to say: "Let the wayward sisters depart in peace." Seward's short vision predicted that it would be all over "in sixty days"! But in great erises the forresight of the wisest is but blindness. Were it always given men to see what they are to go through with, the greatest steps in moral advancenent 


\section{LETTERS AND MEMORIALS OF SAMUEL, J. TILDEN}

would never be taken. Tilden did not foresee, through the storms of war, any more than others, the freedom of the slave with the aequieseence of the master, and the consequent unification of the republic.

But the trials of our popular system of government were not terminated by the simultaneous overthrow of the Rebellion and slavery. It may be, rather, that they have just begun. We were confident before the war that slavery was the source of the only peril which really threatened us. That out of the way, we find ourselves confronted with new dangers, growing out of differences of opinion respecting the extent to which the black race shall be allowed to partieipate in government. That participation is now practically denied by the Southern States, and the mandate of the Constitution is unhesitatingly set at naught by the employment either of force or fraud. The remedy suggested is an enforcement of that mandate by Federal legislation, which means simply the enforcement of its will by one section against that of the other. This is not democratic government, but the rule of the conquered by the conqueror. The evil is bad enough; and the remedy will probably be worse. We begin to see that the real danger which has at all times menaced us is the presence on our soil of a different race, unequal, for the present, at least, to the great office of self-government. Slavery was not itself the evil, but only one of the methods of dealing with it. Is our substitute, the bestowal upon the race of universal suffrage, a successful device? And, if this must be abandoned, what shall next be tried? These grave problems, already threatening, will assume a graver aspect if the results of the census just taken, when studied and compared, shall be found to show a more rapid rate of increase in the black population at the South than in the white. To meet such perils we need nothing so much as a class of statesmen of which Samuel J. Tilden was the most distinguished example. 
LETTERS AND LITERARY MEMORIALS OF SAMUEL J. TILDEN 
•

$+$ 


\title{
LETTERS AND LITERARY MEMORIALS OF SAMUEL J. TILDEN
}

\author{
1810-1844
}

IN 1801 President Jefferson appointed Robert R. Livingston, then Chanecllor of the State of New York, as Minister to France. On his return, in 1804, Livingston brought with him some sheep from Spain, then the home of the famous Merino breed, developed from races of sheep originally introduced into the peninsula by the Romans. In 1809-10 a flock of 4000 Merino sheep were brought into the United States to meet the demand ereated by Mr. Livingston's first importation. The following letter from the father of Samuel J. Tilden, written the very season of the larger importation, justifies the presumption that such importation had been made by Mr. Livingston himself or at his behest. The letter of Elam Tilden was sent to his son Samuel by the late Eliphalet Nott Potter in December, 1882, with a note in which he said:

"In looking over a package of Livingston letters I find the enelosed, and thinking that possibly it may be of some slight interest to you, I beg that you will aceept it with best wishes of the season and for the New Year."

This letter, was written four years before the writer's son Samuel J. was born.

ELAM TILDEN TO HON. ROBERT R. IIVINGSTON

“ New TemanoN, March 19, 1810.

"Dear Sir,-I want to get four or five pounds of your best full-blood Merino Wool to manufacture into cloth for a 
Coat. I applied to you once before for the article for the same purpose, but you informed me, that your wool was all previonsly engaged. I hope, Sir, that you will accommodate me; I can by some means get it forwarded to Iudson, from whence I can get it. I will thank you to drop me an answer by the mail, by which conveyance I will forward you the money, or get it to you by way of my friend, Dr. Younglove, of Hudson, if you accommodate me with the wool.

$$
\begin{aligned}
& \text { "I am, Sir, Your } \\
& \text { " humble Servant, } \\
& \text { "Elam Tilden." }
\end{aligned}
$$

The most disastrous fire with which the city of New York has ever yet been visited is referred to in the following letter. It reduced to ashes pretty much every structure within the area bounded by Wall and Broad streets and the East River, a tract which then embraced nearly, if not quite all the important commission houses in the city; crippled all our insurance companies, and gave to the territory it covered a blow from which, after a lapse of nearly threequarters of a century, it has but partially recovered. Like the great fire of London in the seventeenth century, it is still referred to as the Great Fire of 1835 .

\section{S. J. TILDEN TO ELAM TILDEN}

“ New Yonk, Dccember 17, 1833. Friday, 2.30 P.M.

"My dear Father,--The last has been the most calamitous night New York ever saw. The very centre of the commercial part of the city - from Wall Street across William and nearly to Broad, and to Coenties Slip,-all is a mass of smouldering ruins. A concurrence of unfortunate circumstances rendered the fire thus disastrous. The engines had been much disordered, in consequence of the extensive fires on the previous night - the hose, many of them, frozen and unfit for use. The atmosphere was in a state peculiarly calculated to support and extend combustion, the wind blew with great violence, and the weather was so intensely cold as to clog and almost close up with ice the hose. The flames raged through the whole night with uncontrolled violence, impressing every beholder with the utter impotency of human effort to contend with the 
devouring element. The spectacle was grand and awful beyond conception. I shall not attempt to deseribe it. All the fires that ever occurred here before were perfectly insignificant in comparison.

"The question is now, not who is injured, but who has escaped? Almost all I know are involved in the common catastrophe. At No. 12, Mr. IIicheoek burnt out; Mr. Birch, not even his books and papers saved. Mr. Brown burnt out, and his goods consumed in the street or in the stores to which they were removed. Mr. Starkweather not yet injured, but in imminent danger. Mr. Williams' employees, everything destroyed; and also Mr. Conckling's, I believe. It 14, Mr. Stewart's employees. At 20, Mr. Bronson among the lost; Mr. Soullard, same; Mr. Davis and eseaped. Halsted and Baines, $\$ 40,000$ lost; 20 to 30,000 saved. Hunt and Andrews, Conckling \& , \&c., \&c.

"So vast is the destruction that insurance affords but a very insufficient security. The whole insurance capital of the city will scarce exceed one-half the amount of property consumed in one night! Estimates are very vague and uncertain-the loss, however, can hardly be less than twenty millions of dollars.

"There is not time to write a word more to-day. "Affectionately yours, "S. J. Tilden.

"I have business acquaintanee with a great many of the suffercrs."

Silas Wright took the oath of office as Senator of the United States from the State of New York on the 14th of January, 1833, and in the thirty-seventh year of his age. $\mathrm{He}$ is still regarded in his native State as one of the halfdozen wisest statesmen that ever occupied a seat in the Upper House of our national legislature. He was a warm supporter of the administrations of Jackson and Van Buren, and the most eminent victim of New York's suceessful opposition to the eonversion of the Territory of Texas into five more sovereign slave-holding States of the Union. He was also a close friend and constant correspondent of Elam Tilden and of his two elder sons. 
The letter which follows reached IIr. S. J. Tilden only a few weeks before he was deprived of the Presidency by the 7-to- 6 vote of the Electoral Tribunal of 1876 . It connotes Senator Wright's first appearance in the Supreme Court of the United States. Mr. Waddell, to whom Mr. Tilden was indebted for Wright's letter, had been United States marshal during the administration of Mr. Van Buren.

\section{WM. COVENTRY H. WADDELL TO S. J. TILDEN}

“ Bennett Building, New YoRk, February 26, $18 \%$.

"MY Dear Governor,-I know that you have the highest appreciation of the writer of the enclosed; but I do not know that you have a special taste to preserve interesting mementos relating to such persons. If you have, and will observe the expressions in this letter, you will perceive that W. notes his 'first appearance' as counsel before the Supreme Court of the United States. I beg your acceptance of it for your collection of interesting memorials, and beg you to believe me to be, with sincere regard, "Yours very truly,

$$
\text { "Wir. Coventry H. Waddell." }
$$

\section{SENATOR WRIGHT, OF NEW YORK, TO THE NEW YORK UNITED STATES MARSHAL}

“Senate Chamber, Washington, February 23, 1839.

" MIY DEAR Sir,-The motion in the 'Custody' case was made in the Supreme Court this morning, at the opening of the court at 11 o'clock A.M., and counsel were most patiently heard. Mr. Gilpin, for the Collector, and I myself for the Marshal. It was, as you know, my first appearance in that high court, and the decision is yet to come. All I can say to you is that I made just as good an argument in your favor as I hoped to be able to make. I believe the decision will be in conformity to your wishes, but of that I have no knowledge, except that impression which a lawyer always gets from the argument of a cause.

"Your late letter was duly rec'd. It will give me great pleasure to see you here before we leave, but I shall leave on the morning of the 4 th of March at 6 o'elock A.M. If I get the decision upon the motion in time, I will send it 
to you; but if it is not made so that I can send it to you before I expect you will start for this eity, I will not send it to you.

"I have been called upon to give six notes since I commenced this short note, and I will stop it now, for I do not believe that you can find out what is already written. Rest satisfied that the motion has been made, has been, as I think, very fairly argued, and will be decided, as I think, in your favor; but decided some way in the due course of time, and as I hope before you come here.

$$
\begin{aligned}
& \text { "Very truly yours, } \\
& \text { "Silas Wrigit, JR." }
\end{aligned}
$$

\section{S. J. TILDEN TO IIS SISTER IIENRIETTA}

“ New York, July 15, 1839.

"Mr dear Hetty, - Why don't you answer my letter? If the ring does not suit send it and I can easily change it; if it does, send it that I may have your name put in itunless, indeed, you conclude to come with $\mathrm{Pa}$, which I much wish you would, and, sinee you are not in school, I see nothing to prevent. ...

"I am uncomfortably situated in many respects. I perfectly abhor this mode of life. The social slavery of the family to any scapegrace, man or woman, the latter worse, who may choose to sojourn here is really intolerable. And the whole routine of such an upon-the-town life is opposed to every good habit and in favor of every bad habit. I did hope that when one family left, the burden would be lightened; but it has proved to be only a change of riders. These and other petty annoyances vex me more than they used to; perhaps my temper is at fault; but I assure you they are numerous. And it is unpleasant to me, as you can well understand, to see a disease so full of terror fastening itself gradually but surely upon $\mathrm{J}$.; to see not one thing in the cireumstances to which she is subjected that gives the least hope of counteraction; and to feel myself without power, in the slavish routine of the house, to remedy or prevent. I do not often speak of troubles when I have them, and would do so now only to you; so you must preserve my confidence.*

- Henrietta was the sister of Samuel .T. to whom, on the fifth of the month preceding the date of this letter, for the first and only oceasion 
" $\Lambda$ s to myself, it is only the condition of things at home that prevents me, if I conld make the necessary arrangements, from going abroad. It is the only thing to which I look with any confidence or much hope to act upon my own constitution; and would separate me from circumstances not calculated to lessen the weight of an inevitable misfortune to which I have been long subject.

"I think that if you are able to come now, your visit will be more pleasant than last year.

"Write to me.

"Aff. y'rs,

"S. J. Tilden."

\section{JOIIN M. NILES* TO ELAM TILDEN}

"Wasimngton, Deember 12, 1840.

"Mr DenR Sir,-I have your letter of the 7th inst., and thank you for the copy of the excellent speech of your son, which for the facts it contains, and sound, practical views, is worth more than all the speeches Daniel Webster has delivered on the currency question. The principal article in the Globe on prices and the wages of labor was from my pen, and I am pleased to learn that it met your approbation.

"That measures will be adopted before Congress closes to reorganize the Democratic party and settle on the course of action for the future is so manifestly proper, not to say indispensable, that I cannot abubt it will be attended to.

"Arrangements should be adopted for obtaining the facts from every county, town, and precinct in the Union, in relation to the foul frauds practised in the late elections. The statements and certificates of these facts should be verified by oath when it could be done; and the whole ought to be published in a volume and put into the hands of every honest elector in the United States. This mass of information would be used by the Democratic papers as they might have occasion.

in his life he opened his mind on the subject of matrimony, a topic at that time of serious concern to her. See Bigclorr's Life of Tilden, Vol. I., p. S0. Before the expiration of the year of which this letter bears date, she died. The brother when he wrote this letter was living with an aunt who kept a boarding-house at what was then the upper part of Broadway.

* Proprietor of the Hartford Times at the date and United States Senator from Connecticut. 
"It is true, as you say, that the battle is not yet really begun; the true issues which divide the Democracy and the Federalists cannot be presented before the country except the latter are in power. 'They are then forced to come out with their measures and disclose their prineiples.

"There will be a glorious fight for the next four years, the result of which, I confidently believe, will be highly auspicious to the Democratic eause and the preservation of our popular institutions.

"I am, respectfully,

$$
\begin{aligned}
& \text { "Y'r ob't ser't, } \\
& \text { "JoHN M. Niles. }
\end{aligned}
$$

\section{"E. Tilden, Esqr., \\ "New Lebanon, "New York:"}

President IIarrison died just one month after his inauguration, a casualty from which the Whig party never fully recovered. To the Congress which convened in extra session May 31, 1841, President Tyler intimated his desire that the members of that body should request a plan for a national bank from Mrr. Ewing, then Secretary of the Treasury. In pursuance of the resolutions for this purpose adopted by both Houses, Mr. Ewing sent in a bill for the incorporation of the "Fiscal Bank of the United States," the essential features of which were framed in accordance with the President's suggestions. The bill passed Congress August 6, with a clause concerning branch banks differing from Mr. Ewing's, which was vetoed by the President. The letter from Mrr. Tilden which follows was a criticism of this bill, and probably had something to do with its untimely fate.

It does not appear from the eopy to whom this letter was addressed by Mr. Tilden, but it was probably to Senator Wright.

Congress subsequently passed another bill intended to meet the objections of President Tyler. He concluded he could not approve it without inconsistency, and therefore vetoed that bill also, by which act he alienated the United States Bank wing of the Whig party to such an extent as 
to make many friends among the party of the opposition. It is to that phase of that absorbing bank issue at Washington that Mr. Tilden refers in the succeeding letter to Mr. Nelson J. Waterbury, then a very earnest, active, and intelligent Democratic politician, a few years Mr. Tilden's junior.

\section{TO MR. NELSON J. WATERBURY}

“New Lebanon, September 11, 1841.

"My dear Waterbuly,-On a flying visit of a few hours, which I made to the city some two weeks ago, I received your letter, but I was so busy in running about the country that I did not get a chance to answer it.

"You judge rightly as to my sympathy with your sentiments and action in regard to the veto. Our line of duty is plain. While we render to Tyler liberal credit for every good act he does, and sustain every right measure which he proposes, and defend him against the unjust and unconstitutional attacks of the Whigs, we cannot give his administration an unqualified support, or commit ourselves in favor of his re-election. So far, we agree with him only on the bank question-and there as to act of the veto, not as to its reasons, which are qualified and hesitating, and mingled with crudities and unsoundness; while as to the other questions-some of which are of great, if not equal, importance-we differ from him. If his course had been less objectionable we ought still to keep ourselves uncommitted as to the succession. We cannot enter into a bargain of office for measures. Whatever he does right, he must do spontaneously, and we will frecly and heartily support, leaving the future to take care of itself.

"I never regarded Tyler as a man of very high capacity, and his public documents since he has been President have not increased my estimate of him. The last veto-which I have just read over-is better in matter and manner than the former, which was very objectionable in principle, but neither of them is creditable.

"I will confess that at first I was not without apprehensions that Tyler's course might be such as to conciliate a portion of our people, and weaken the efficiency of our action, while it would not be such as we could fully approve or safely support; and that he might construct a half-and- 
half administration in which real and thorongh democratic principles might suffer more than by open hostility. But my fears are diminished. Our people seem to be taking the right ground; and the enthusiasm at first excited will, I believe, settle at about the right point. $\Lambda$ gentleman to whose opinion I very much defer thinks that Tyler is not a man to acemmulate any political strength around him; and can in no event be dangerous.

"I do not know whether the Whigs will attempt to put in exeention any of the desperate neans which have been shadowed forth-such as a formal demand by the members of Congress for Tyler's resignation-a rejection of his nominations of ofticial advisers in case the present eabinet shall retire - a systematic clamor to intimidate him to a surrender of his constitutional authorities. If they do, we must stand by him and his offieial rights to the uttermost.

"I intend to return to the city in about three weeks. Meanwhile I shall be partienlarly glad to hear from you.

"I thank you for the paper you were so kind as to send me.

$$
\begin{aligned}
& \text { "Sincerely y'r's, } \\
& \text { "S. J. TILden." }
\end{aligned}
$$

\section{SILAS WRIGIIT, JR., TO FLAM TILDEN}

"Wasmington, December 6, 1841.

"Mr dear Sin,-Your favor of the 15th ult., directed to me at my home, eame round to me here on this day. I left home on the day of the date of your letter, and when $\mathrm{I}$ reached New York found you had left there but a day or two before. I had a very pleasing visit from your son at my room at the City Hotel, but should have been greatly pleased if your visit to the eity had been prolonged, as my stay was unusually long and I could have seen more of you than I have been enabled to see for many years.

"Our victory has been truly great and gratifying, and yet your strong, practical thinking has, in my judgment, brought you, as it almost always does, to a correct conclusion as to eonsequenees. If the Whigs had retained the Senate for this year it would probally have been easier for us to have regained the State completely next year. We must not, however, complain of prosperity, and especially when it comes, as I think it has come now, by the sole ener- 
gies of "the sober second thought" of an honest people. We must meet the crisis as it meets us. We must show the people the truth as to our finances, and then act as honest men would act, determined to pay their debts and avoid insolvency. Everything hangs upon the action of our Legislature during the coming session. If our friends in that body are bold and frank and honest the people will sustain them, but if they underrate the intelligence and patriotism of the people and continue the attempts to humbug them and to purchase their good-will by their own credit sold in the market at eighty cents for the dollar, we shall as certainly be beaten next fall as we have beaten the Whigs this. These seem to me to be truths so plain that no one can mistake them, and I still tremble with fear lest some of those elected to the legislature as Republicans may, from mistaken riews, from apprehensions of local expediency, from selfish interests, or from some other improper or unwise impulse, urge a continuance of our system of extravagance and resist the measures indispensably necessary to a return to health and soundness.

"I have little fear of what may be done here beyond what was done at the extra session. An effort will doubtless be made to rouse the tariff feeling again, but our point, as I think, should be to raise no more revenue in any way, or for any purpose, until the land-distribution bill is repealed and the system of giving away the revenue we have is formally abandoned.

"I lave very little hope from President Tyler, except that he may prevent some mischief which his party would otherwise do. I do not think there is enough of him to build upon, or that he has enough of the democratic prineiples and sympathies left to govern him.

"I have not a moment of time more. Please let me hear often, and believe me,

"Elam Tilden, Esq.

"Most respectfully, "And truly yours, Silas Wriglit, Jr."

SILAS WRIGHT, JR., TO ELAM TILDEN

“WAShington, January 29, 1842.

"MY DEAR Sir,-Your letter of the 1Sth Dee. has remained a long time without an answer, and I cannot now answer it, but a single subject collateral to it. 
"Within the last two days I have received two letters coneerning your Post-Oftice matters, which have deserved and received my attention. I camnot do here all my friends ask, and have a right to ask, and from me especially, deserve, but I try to do all I can; and yet unselfishness and indolenee may often induee me to think that I do what I can, when I might do much more. I fear I have exhibited myself to you in this way in reference to your Post-Ottice. But of that I have not time to write, nor do I wish you to think, as I know you give me more eredit for faithfulness than I merit, and I give you every possible credit for valuable and faithful friendship. I will, therefore, to the New Lebanon Post-Office.

"Mr. Edmunds and Mr. Bryant, of the Evening Post, are the gentlemen to whose letters I refer. As the Senate did not meet to-day, I have had the day to devote to business of this character, and I have just returned, at 3 o'elock P.x., from a lay most pleasantly spent in attention to them.

"Upon a personal call at the Post-Office Department I learned that, in September last, an application was made to have the name of the post-office at the Springs changed from that of 'Columbia IIall' to that of 'New Lebanon Springs,' and to have Mr. Bull removed as postmaster and Mr. Nichols appointed. Both these things were done, and Mr. Fuller, the $\Lambda$ ssistant Postmaster-General, who has the charge of the appointments, supposed at the time, and now supposes, that the effect of that action was to remove the office from the Springs to Lebanon village, the location of the New Lebanon post-office, when you kept it. I suppose he is wholly mistaken, and as you are a matter-of-fact man, I wish you to send me papers properly signed by such disinterested men as you may see to be the most proper men, showing where the office was kept under Mr. Bull and where it is kept under Mr. Nichols; and in the same papers you may show, if you please, where your office was kept and where the office you formerly held is now kept. Let the papers be directed to the Postmaster-General, and have no political, but a mere local bearing, and make a map which will be plain, and if convenient let the men who vouch the facts be Whigs as well as Democrats.

"You must find my apology for this very hasty and badlooking letter in the fact that since $\mathrm{T}$ began to write it I have heard of the death of a member of our body, Mr. 


\section{LETTERS AND NIENORIALS OF' SAMULL J. 'TILDEN}

Dixon, of Rhode Island, and have been summoned to attend his remains and participate in arrangements for his funeral, and I have been anxions that this shonld go tonight and found it would not if I did not enclose it before I left for that solemn duty.

"Elam Tilden, Esq."

$$
\begin{aligned}
& \text { "Most truly yours, } \\
& \text { "Silas Wrigit, JR. }
\end{aligned}
$$

SILAS WRIGIIT, JR., TO ELAM TILDEN

"Washington, February 13, 1842.

"MTr dear Sir,-I have but a moment to say that your favors of the 4th and Sth and the docments in relation to your P.-O. affairs all came to me together on Friday evening. I saw Mrr. McClellan yesterday, and we have agreed to make a visit to the Department together on some day this week, when we can both find leisure to do so, and if possible bring the matter to some final termination.

"I consider it now perfectly certain that either Mr. Tyler must submit unconditionally to Mr. Clay, and must place the administration in his hands or that open and desperate war is to be carried on, not against him simply, but against his administration, for the future. And yet he is daily removing from office our best and most worthy men, even those whom the Whigs dare not attempt to remove, under the delusive idea that he is filling their places with Tyler men. When he shall call upon them he will find them where the great body of his party now is to him, missing and enlisted under another leader.

"In haste, I am, :

$$
\begin{aligned}
& \text { "Most truly yours, } \\
& \text { "Silas Wright, Jr." }
\end{aligned}
$$

\section{VAN BUREN TO S. J. TILDEN}

“Lindenwald, October 24, '/2.

"Mr dear Sir,-As you forgot my former commission, I trouble you by way of revenge with one something like it. I owe the clever editor* of the Spirit of the Times the amount of the within check, which I wish to have paid to him, and his paper discontinued. As this, that is, the discontinuance, 
is at best an ungracious act, I wish to have it performed in the most gracious way, and therefore commit the matter to your hands. I am, doubtless to my shame, not much of a sportsman. I have not, therefore, read his paper as attentively as others, but I have seen enough of it to impress nie most favorably, not only in respeet to the talents, but the just and honorable bearing of the editor. It would, therefore, afford me pleasure to continue the Times, if the number of political papers which I feel myself bound to take did not render my expenses in that line too heavy for a farmer's ineome. If there is an objection to diseontinuing until the end of the year I will, of course, take it till then.

"Excuse this trouble, and belicve me to be

"Very sincerely, your friend, "MI. VAN Buren."

RECOMMENDATION OF S. J. TIIDEN FOR THE OFFICE OF ATTORNEY FOR TIIE CITY AND COUNTY OF NEW YORK

"To the Democratic Members of the Com. Council:*

"The undersigned, members of the Bar, recommend Samuel J. Tilden for appointment as Attorney to the Corporation. Mr. Tilden's services and qualifications are such that in our opinion his appointment would give the highest satisfaction to the Democratic party, the legal profession, and the public generally.

"I sign the above most cheerfully:

“New York, A pril, 18 \$3.

Lewis H. Sindford,

Joinn R. Livingston, Jie,

C. I. S. K.Ne,

Cins. B. Moore,

I. Roninson,

Shinel A. Cripo,
William S. SeArs,

D. D. FIELD,

Cits. G. Illvens,

Jimes J. Roosevelt,

C. McLean,

Theonore Sledgwick,

Hawks \& Scoville.

"I checrfully concur in the foregoing recommendation: Thos. R. Lee,

P. Reviolos,

Latrmor S. EDin, Wr. McMurke."

* The place of attorney for the City and county of New York for which this address to the Demoeratic members of the Common Council, was the only office Mr. Tilden ever held hy appointment. He held it but about one year, during which time he docketed 123 judgments for violations of eity ordinances. 
The nomination, election, and inanguration of Senator Wright as Governor of New York State, in 1844, gave Mr. Tilden a greater influence perhaps than was possessed by any other individual in the dispensation of the patronage of the Excentive at this time. His friend, John W. Edmonds, in whose office he had studied his profession, a native of the same county as himself, and a lawyer of considerable ability, was anxious for the appointment of Surrogate of New York city. Though he failed in this effort, he subsequently was appointed one of the Justices of the Supreme Conrt, largely, not to say entirely, through Mr. Tilden's influenee.

By the spring elections of 1844 both the old parties were thrown into confusion and driven from the field by the "Native American" party, so called, which appeared with a suddenness and force of a tropical cyclone and swept the comntry.

The friends of Mr. Van Buren in New York naturally looked to Mr. Van Buren as their candidate for a renomination to the Presidency. He was defeated, however, in the national convention, and James K. Polk, of Tennessee, received the nomination. The following letter from $\mathrm{Mr}$. Tilden to his brother is the only account we have from his pen of his experiences in that convention to which he was a delegate. Unhappily, the manuscript is incomplete.

\section{S. J. TILDEN TO IIIS BROTIIER}

"Baltimore, May 2\%, 1844.

"Mr deAr Brother,-Here we are in a state of extraordinary excitement and great meertainty. There is a deep and almost universal disaffection in the Sonth. Virginia is against us by a large majority, also North Carolina, Ga., Miss., Ark., La., probably Maryland, Indiana; New Jersey, Michigan, Alabama, Ill., Conn. donbtful; N. Y., Missouri, Ohio, N. II., Vermont, R. I. reliable; Penn. instrncted and ready to vote with us on the main question, but liable, some of them, to cheat on collaterals.

"We have a small fixed majority eertain on the first ballotings, but some of the Penn. delegates and probably 
some others may be and probably will be inelined very soon to desert. But the plan of the disaffected is to require a two-third rote to make a nomination. 'This, they think, and probably with eorrectness, that Mr. V. F. cannot get, and then they may bargain with those who vote with us but are not hearty in our cause. Some of the Penn. men who are instrueted and are therefore obliged to vote for $V$. B. would prefer Buchanan - have been approached by propositions from the South to bargain with them, with what effect we (annot know."

\section{"Private.}

$$
\text { SILAS WRIGHT TO S. J. THLDEN }
$$

"Washington, May 10, $18 \%$.

"MY deAr Sir,-Your letter came safely, but yon will have conjectured, from the public appearance of things here, that some of us have been rather busy for some days past. I have but a single moment now to say that if you shall have neeasion to send papers here for distribution, Mr. Stevenson will do the labor, so far as you shall direct addresses, and we will see that others are obtained here, but we cannot send your franks.

"I have only completed the speech to-day, and it eertainly is not better for having been written out amidst the unexampled exeitement of the last two weeks. $\Lambda$ part of it will appear to-morrow, and the residue on Monday evening, and I will take a pamphlet eopy, when I get one, and mark it off as you suggest, by proper heads to the divisions.

"Please inform me, as soon as you reecive this, if $\mathrm{Mr}$. Butler has returned. I want to communicate to him on the subject of the eonvention as soon as lie reaches, if he is not yet home.

"A letter from Cambreling received to-day tells me that he is off for Carolina only to return to the Convention. Te ought to be at hand to meet the delegates in New York when they should have a meeting.

$$
\begin{aligned}
& \text { "In very great haste, } \\
& \text { "I am, truly yours, } \\
&
\end{aligned}
$$

"Saml. J. Tilden, Esq."

The triumpl of the Native American party and the eleetion of Mr. Harper for Mayor led to a general and prompt 


\section{LETTERS AND MEMIORIALS OF SAIIUEL J. TILDEN}

change of all movable officers of the municipal administration. Mr. Tilden tried to anticipate the party proscription, but by some mistake, the nature of which is illegible in the following letter, he had to undergo the proscription of the victors, which, however, neither politically nor financially involved any personal sacrifice.

SAMUEL J. TILDEN TO R. I. SHIEFFELEN, ESQ., PRESIDENT OF THE COMMON COUNCIL

"New York, May 25, 1844.

"To the Honorable the Common Council of the City of New York:

"I have expected at each of your meetings to be removed, but have been disappointed. In case my successor as Attorney to the Corporation shall not be selected this evening, I respectfully present to you my resignation, to take effeet on the day after your next joint meeting, until which time the public interests entrusted to my care shall not be embarrassed.

$$
\begin{aligned}
& \text { "I am, respectfully, your, \&c., } \\
& \text { "Shaudel J. Tilden." }
\end{aligned}
$$

Comparatively recent note in pencil in Mr. Tilden's handwriting:

"In the haste of preparing to leave the city for the Baltimore Convention this wish was omitted, and while I was there I was remored."

Senator Wright yielded very reluctantly to the irresistible pressure of both divisions of his party that he should aecept the nomination tendered him for Governor at the fall election of 1844. It was apparent to the friends of Mr. Polk that he could not carry the State of New York without the support of the friends of Mrr. Van Buren and Wright, and no less of a sacrifice than the transfer of Mr. Wright from the Senate to the Governorship could make the State reasonably seeure for the Presidential ticket. How reluetantly Mr. Wright yielded to this pressure is not to be measured solely by his far-sighted doubt of its policy 
and of the advantages of a vietory for the Slavery-Extension party at that time. He had other reasons of a domestic nature presented some three years before in a most pathetic and touching letter addressed to Mr. Tilden's father.*

The logic of the situation presented by Mr. Wright's nomination for Governor in 1844 required that he should by his election save the Presidential ticket and then "sneceed President Polk in 1848 or retire from public life," and Mr. Marey to defeat Mr. Wright's re-election as Governor, or himself retire from public life. It was practically to engage in such a thel that Mr. Wright went to Albany and took the oath of office on the 1st of Jamuary, 1845. Me had in his favor a great parliamentary reputation, and a character for wisdom, probity, and political sagacity, enjoyed in a superior degree by no other American statesman of his generation.

On the other hand, he had to contend with an administration in whose eyes all these virtues, when enlisted against slavery, were regarded only as so many additional reasons for erushing their possessor. He had also to contend with a very considerable number who still ealled thenselves Democrats, but who had deserted the party from mistrust of the suceess of its financial policy, and who were impatient to recover some sort of party standing.

Mr. Tilden engaged in this canvass for President Polk with more zeal than in any other exeept, perhaps, the last, in which he was himself a candidate, and in both instances was betrayed by his party.

Not the least efficient of his scrvices in this campaign was the establishment of the Daily Ncws in connection with John L. O'Sullivan.

\section{O'SULLIVAN'S PLAN AND ESTIMATE IN REGARI TO TIIE "MOLNING NEWS."}

\section{July 13, 18:1.}

"Outline of plan of arrangement for" the paper between S. J. 'Tilden and .J. L. O'S.-proposed by me.

$$
\text { “J. I. O'S. }
$$
102

* This letter first appeared in print in the Life of Tilden, Vol. I., p. 


\section{LETTERS' AND MENORIALS OF SAMUEL J. TILDEN}

"1. The entire concer'n to be owned in equal halves by S. J. T. and J. I. O'S.

"2. Ary disagreement of opinion ever arising, if requiring a decision, and irreconcilable by discussion, to be determined by reference to B. F. B. or some other friend, unprejucliced in the matter.

"3. In case of either party ever desiring to withdraw, the other to have the refusal of the purchase of his interest, on equal terms with those offered by any one side, or of any portion of the same at proportional rate.

"4. In case of failure of the enterprise and both desiring to give it up, the materials purchased to be rested in trust in (query - the Chairman of the Gen. Committee - or Young Men's Gen. Committee?-or B. F. B.?)-for the benefit of the Demoeratic Party. This is to be determined within six months. If one desires to give it up and the other does not, at the end of six months, or before, the whole property then to become absolute in the one remaining.

"5. Neither to place the firm under any debt or obligation without the consent of the other.

" 6 . The business machinery to be managed by a Chief Clerk (Guion), at a salary of $\$-$, and $1 / 10$ of profits.

"7. The estimate of profits of the concern to be made after the allowance of editorial salaries. S. J. T. and J. L. O'S. to be entitled to draw a sum not exceeding $\$ 30$ a week apiece, for editorial labor and time. Each to do this at his own discretion, and according to his own estimate of a reasonable compensation for his labor and time. If hereafter, from regard to health or other cause, either should desire to withdraw for longer or shorter period from active participation in editorial charge, the other remaining in charge to be entitled to an editorial salary of $\$ 2500$ per annmm. In case of death of either, the other to inherit his share, subject to an annuity for ten years, according to direction of the deceased, amounting to one-third of that portion of the general profits which would otherwise have been divisible between the two-the salary of $\$ 2500$ in that case being allowed to survivor for editorship.

"No other points now oceur to me requiring provision. “J. L. O'S.

"It is possible that Mr. Waterbury may desire to have some connection with the paper, which will be in that case 18 
perfectly agreeable to me. The amount to be allowed him for his serviees in it, in that event, whether in the form of a certain proportion of profits, or part salary and part proportion of profits, I leave to be fixed by you. I should like also myself to employ my brother in it, if as elerk and general aid his serviees should appear desirable, his eompensation being fixed between us, ranging above a certain small minimum, aecording to his serviees and the ability of the concern.

\section{"J. T. O'S."}

\section{TILDEN TO}

"New York, A pril 25, 181\%.

" $\mathrm{M}_{\mathrm{Y}}$ deAr Sir,-I returned three days since, and have been trying to get an opportunity to write to you without suceess until now. 'The prospect of overeoming the peemiary obstacle appears farorable. A few days will decide the question, when I will write to you more partienlarly.

" $\Lambda$ modification of the plan is meanwhile being attempted, which, if suceessful, must greatly increase its usefulness. It is, if possible, to get the $\$ 5000$ absolutely; with a condition that if we cannot get a subseription of 25,000 or deem it wise to publish a less nmmber, we shall have the same value in such printed matter as we may cloose, and additional matter at cost; which we ean cireulate in what way we may think best. My own opinion is that, as a general rule, it should be sold, at or below eost, which will itself be very low if the quantity is large and the work managed economically. It seems to me that in this mode we conld circulate $2,3,4$, or 5 times our actual capital; that we should tempt purehases from every part of the country, and make the most extensive and effieient use of our money.

"Of course there are a great many details to be contemplated in arranging so large a machine: I camnot now state them sufficiently even to explain my snggestions, but hope to be able to speak more definitely in a few days.

"Mr. V. B. was perlaps less impressed with the importance of the paper than yourself, and circumstances of delieacy prevented my taking that view of the subject. Nevertheless, he was anxious to have it undertaken, and, sinee my return, tho $I$ have in no measure availed myself of the aid which he was willing to render, our people seem 
better inclined than I expected. Still, the experiment cannot be regarded as tested."

\section{SENATOR SILAS WRIGHT TO TILDEN}

"Senate Cilamber, Washington, April 11, 1844.

"Mr DEAR Sir,-Maving labored in vain during the whole of yesterday to find time to write to you my promised letter, and not having approached the probability of such leisure between 8 o'clock A.M. and 12 o'clock p.M., I now take my seat for the purpose.

"I have conversed as extensively as I could with our Western friends upon the subject of the paper of which we take, ${ }^{*}$ and all I ean say, as to the result of my conferences, is that no dependence can be made upon them, beyond a reasonable effort to extend the subscription, in case we shall conclude to take the hazard of making the attempt to establish the paper. The same feeling of which I spoke to you has produced the influences I supposed it would, and it, together with the efforts we are making here to distribute documents, has cooled the anxiety formerly expressed for such a paper, and especially so when a suspicion arises that the man's own pocket may be connected with the effort to establish the paper.

"Still, I confess, I lave not been able to diminish, to my own mind, the importance of such a paper to our cause. I think our State press, as a general remark, in a very bad state for the pending contest. The country press has been, time immemorial, accustomed to look to the Argus for lead and tone in these great fights, but the Argus, during the whole time we have been here, appears to me to have been insensible of the pendency of the contest, as perfectly unaware of what appears to me to be its true character. It is not my object to complain of the Argus, and I doubt not that the singular and very unfortunate state of things at Albany has embarrassed its cause, and perhaps presented reasons for its silence upon national questions, of which I am ignorant. In any event, the Argus furnishes no lead to the country press; we have no weekly general paper, and the Whigs, through the showers of the Tribune which they

* The paper here referred to was the New York Daily Neus. For an account of Tilden's connection with its establishment and management, see Life of Tilden, Vol. I., p. 108. 
are pouring over the State, are doing much to get the start of $11 \mathrm{~s}$ and to turn the eurrent of feeling with the impulsive and muthinking against us. At least these are my fears, and it seems to me that these must be the natural consequences of constant effort and allegation and falsehood on the one side, and comparative silenee upon the other. Of this, however, our friends at home ean julge much better than I ean, and I therefore renew the adviee I gave you before we parted here, to go and make Mr. Van Buren a leisurely visit, and take his comisel and advice about the whole matter, and act as he shall think best.

"You will not be surprised when I tell you that the news from your charter election * has thrown everything liere, for this norning, into that state of exeitenent and confusion which renders it tronblesome for one to keep cool and goodnatured loth. After some months of constant session, the atmosphere becomes so thoroughly tainted here, and the memlures of Congress themselves beeome either so far corrupted, or so lost in their remembrances of home and what the people really are, that they are really more elikdish and more excitable than so many children, and it takes more patience than I can command to hear up against their whims. In the result of your chater election I have experienced little disappointment, and see no great cause of alarm. If our press would improve the arlvintages it presents, it appears to me it could not fail to fix the Irish and other emigrant vote throughont the country; but in this, as in other things, I fear we shall feel the want of some paper which is recognized as having a lead and giving the facts and the aims of the whole party. The Post is well edited for its place and circulation, but its exchange-list, I suppose, is not the broadest, and it never has been looked to for the party lead. I say this in no disparagement to Mr. Bryant, for no one lolds him in higher estimation than I do, and it is our own fault and not his that his paper has not held the leading place.

"But I must return to the subject of my letter, and writing, as $I$ do, in my seat, and in the hearing of an exrited dehate, I can say little more, even upon that. You ean tell Mr. V. B. all our views about the proposer establishment of a paper as fully as I could repeat them to you

* The triumph of the Native American party. 
as to him if I had the time, and if he shall think that we overestimate our need, or the utility of such a paper, if established, I shall be perfectly content that any farther movement be abandoned. If he thinks it best for you to consult any of our friends at Albany he will tell you who and how. You will let him know, too, that the reason we did not think of Albany, rather than New York, was that we supposed the state of things and state of feeling there to be such, and the relations to our two papers there, those which would be likely to defeat any movement made there with this view, or compel it to be made either against active opposition from our own friends or under dissatisfied feeling on the part of those connected with one of those papers.

"It appears to me that if anything is to be done it should be done quietly, so that the paper may commence with the nominations. I do not doubt, if subscribers are sent here to be distributed, that many, very many, subseribers will be obtained from without the State, and especially from Indiana and Illinois, and probably from Ohio and Michigan, but to that end all the time which can be given will be desirable.

"I must close, for I have been listening to speeches, while writing, until I do not know what I have said or what I wanted to say. After your return let me know the result of your mission as soon as you shall find leisure.

$$
\begin{gathered}
\text { "I am, most truly, yours, } \\
\text { "Silas WRIGHT. }
\end{gathered}
$$

"Private.

"N. B.-I shall write to Mr. V. B. upon this subject by this mail, and I think it not best for you to go up until after my letter can reach him. May it not be best for you to drop him a note, saying that you propose to make him a visit, naming the day, and telling him the subject is that of a paper, about which you suppose I have written to him?

"S. W."

\section{SILAS WRIGHT TO S. J. TILDEN}

"Wasinngton, April 30, 18\%.

"Mr denr Sir,-Your letter has come, and I have read it with deep interest, but have not time to give you any answer beyond a mere note. Events follow so thickly upon us now that I cannot promise when I shall have another hour at command. The speech has been made, but it will 
never be written, if I am overrum as I have been ever since it was spoken.

"Mr. V. B.'s Texas letter is producing the fever and fury which I expected, but I lope feeling will, bye and bye, settle down to a better state. There is great talk now of another candidate, as a third eandidate, but the members who join in the novement are, as far as I can learn, much less in number than was expeeted, being, as is said to-day, only about 20 . I think the number will grow less.

$\therefore A$ single word about your effort. Do not involve yourself pecuniarily. If you cannot see your way clear without that, let it go, for it is not your duty to ruin yourself, even for such an object. Your views of the indispensable neeessity for minute organization are perfectly sound.

"All I can send to you is some copies of the Philadelphia Club preparation, as I eannot get time to draw ont in detail what I have suggested for my own and other counties. You will do that better than I can. I am called.

"In great haste,

"Most truly yours,

"Silas Wright."

\section{$1845-1850$}

Tine purpose of the advisers of President Polk to prostrate the political organization of which Mr. Van Buren and Governor Wright were the most conspieuons representatives was searcely disguised in the appointment of Mr. Van Ness as Collector of the Port of New York. Their part in preventing the organization of five more slave States, with their ten pro-slavery Senators, instead of one State with but two pro-slivery Senators, was such an offence to the Nullifiers of the South that the President, a citizen of a slave State, was compelled very reluetantly to yield to it and use his patronage accordingly.

The effort was made to seluce 'Tilden from his allegiance to his friends in New York ly the offer of the naval office, then a luerative and honorable position. Tilden had hut just completed the thirty-first year of his age; the enoluments of the office were some twenty thousand dollars a year; the labor and responsibility inconsiderable. Tilden was poor, 
and many rears must elapse before he could hope for any such revenue from his profession. The offer, however tempting it was, he promptly deelined, saying that he did not labor for the election of President Polk to push his private interests; that when he was admitted to the bar he resolved that he would hold no merely lucrative office, and that, if he took any, it must be in the line of his profession or a post of honor, but under the then existing cireumstanees he could accept of nothing from this administration.

From this time forth there were practically two Democratic parties, so ealled, in the State of New York: one led by William L. Marey, and vulgarly known by their adversaries sometimes as "Hardshells," and sometimes as "Hunkers," who were either in favor of or not opposed to the extension of slavery into the free Territories from which it had been exeluded by the ordinance of 1789 ; and the other led by Silas Wright while he lived, also vulgarly known sometimes as the "Softshells," and sometimes as "Barnburners," who were opposed to the extension of slavery into those Territories.

Though the division lines of these parties, like those of latitude and longitude, were not visible to the eye, nor the parties themselves sufficiently organized to oceupy hostile camps, the ends towards which they were severally working were quite as distinct as if they were.

The following letter was probably addressed to William L. Marcy, who had allowed himself to be.made the instrument of the pro-slavery eontingent in New York, and had been on that aceount selected by the President as his Secretary of War.*

\section{S. J. TILDEN TO}

"New York, 1845.

"I cannot give you in full detail the grounds of the almost universal odium with which Mr. Van Ness is regarded by the Demoeracy of this eity and State, but will briefly allude to some of them.

* Letters from Tilden intended for Marey were commonly addressed to Marcy's brother-in-law, Mr. Newell, who resided in Washington during Marey's war ministry. 
"Ilis appointment was not originally recognized as a 1) enoeratic one or received from a recognized Democratic President. He was personally and politically a stranger; did not oecupy that proper representative relation to the party here to make his selection proper or acceptable, or to give him or entitle lim to their eonfidence. On the eontrary, all that was known of his private character and of his political tendencies was calculated to repel such eonfidence.

"IIis conduct since has confirmed and exacerbated the sentiments with which his original appointment was rogarded. In his offieial action and his politieal influenee he has been the mere representative and instrument of a miscrable little faction, whose fortumes he has solved equally when it was in a state of partial alienation and open hostility to the Demoeratic party and its regular nominations. For months after Mr. Polk's nomination, for two-thirds of the whole eanvass, he was an open and decided supporter of Mr. Tyler. All sorts of intrigue were employed by this little band of officeholders and their dependents to exact from the mass of the party a partial approval of Mr. Tyler's administration and an adoption of his appointments as a condition precedent to his withdrawal. Such had been the abuses and corruptions of his administration in the use of its patronage here-incredible to those who like vourself have looked upon them from a less central position-and shocking to the moral sense of honest men of all parties; such was the general disgust and hostility pervading the masses of the Democraey which had been for several years vexed by the abnses and corruptions of the government patronage employed for the purpose of distracting the party; so large was the number who had been the subject of exclusion and proseription because of their very political ficlelity, and so large also the number who desired a new distribution of official farors, that such a concession as was demanded wonld lave revolted public sentiment, in all probability have lost this (ity by a very large majority. Snch was the conviction at the time of our soundest and most judicions men, who kindly and temperately but firmly resisted and defeated the project.

"The perilous crisis in our local polities you may form some idea of, if you will remember that there were then, delicately poisod and uncertain to go for Clay or Polk until 
within a few weeks of the election, a body of men more than sufticient to have changed the result in this State. Mrr. Polk has now to choose between the $19 / 20$ ths of the party and this faction; between the disinterested and honest who were true to his and the party's interest, and the venal gathered from all former parties into the common receptacle of Tylerism, who would have sacrificed both to their own mereenary objects. His choice between them will indicate the morale of his character and administration. Ever since Mr. Tyler's attempt in 1841 to become the Presidential candidate of the Democracy, the patronage of the government in this eity has been assiduously employed to harass or control the party here. It was managed by Mr. Curtis, who was skilful in if not the originator of all the corrupt tacties of the Glentworth school; and sinee his removal, his machinery has been used by Mr. Van Ness [with] much more industry and zeal and with no less profligacy."

\section{TILDEN TO WM. H. HAVEMEYER* (PROBABLY)}

\section{“Wasuington, March 4, 1845.}

"Mr pear Sir,-I have received your letter of yesterday, which is much more acceptable than your personal presence. Indeed, I suppose that your intelligence from Albany would have changed the design, even if you had entertained it, of coming here. I did not expect you to start before Mon. morning.

"As far as your personal position is concerned, it is sustained by your renewed declension-perhaps uttered, although that it did not need. For be assured that nothing has been done to bring in question, the sincerity and reality of your declension, as well as the good faith of your grounds, but everything to satisfy both. It, however, does lessen our right, or apparent right, to complain of the precipitancy of Mr. Polk's action before the receipt of Mr. Van Buren's letter.

"I judge from your letter that every time the excitement

* Twice Mayor of New York City.

$\uparrow$ Mr. Tilden on Saturday, after seeing Mr. Polk and delivering my letters, and perceiving a disposition to make the appointment finally made, wrote to me to come on in advise. 'This I declined, believing the matter disposed of, as proved to be the fact. The letter to Gov. M. was mailed at Washn. on Saturday P.M.

IV. H. H. 
of the particular motive operating on your mind for the moment to accept any department, subsides, your aversion returns and strengthens. 'This shows that it is the predominant and settled conviction, which ought not to be, without imperative necessity, disregarded, and applies even in the - case of a recast. In this connection, I shonld add to the hasty view of the affair I yesterday gave yon that Bancroft thinks that if you had accepted the War a recast conkl have been had, and intimates the possibility as if from the President. This may be so-others have thonght so the whole time-but I doubt, for reasons I will explain when I see your.

"Last evening we had an interview with the l'resident. Representations had been made to him which were repeated by us and which he said convinced him of his error, but it was now too late to retract if the Heavens and the Earth came together. He assured us that he had acted from misinformation, and with the best intentions-that he would do all he could to counteract the consequences of his error -that he should be President himself, although not eoming in with the same personal strength as some of his predecessors, and would protect us from any malign inflneneesthat in regard to the important appointments in $\mathrm{N}$. Y. he would rely on his old friends and act with the concurrence of $\mathrm{V}$. B. and $\mathrm{W}$. Te has repeatedly and to different persons pledged himself as to the Collector. IIis asseverations of attachment, fidelity, and fair dealing towards N. Y. were carnest and strong, almost passing dignity, yet with an air of sincerity which made a strong impression as to mere personal intentions.

"Still I have perhaps more fears than hopes. The aduinistration is captured by the quasi-Van Buren men who went with us hefore Baltinore but deserted us there; who cannot risk the power of the goverument in those who nulerstand and remember them; and confederate now against Wright. At least that scems to me the inflnence-which in spite of Polk's probable intentions - has shaped the Cabinet. Calhoun has no share. There will be no one in the Cabinet on whom N. Y. ean rely. Buchanan you know. Walker has a strong will enough to predominate over all the rest. Marcy is taken by the sane influence which selected Walker because while he answers some of the demands of deceney towards $\mathrm{N}$. $\mathrm{Y}$. is least identified with Wright. 
Mason, Atty. Gen. (unless son. How can Bancroft stand up to James) and R. Johnagainst all the others? "Truly y'rs, "S. J. Tilden."

\section{NELSON J. WATERBURY TO TILDEN}

\section{“New York, March 8, 1845.}

"Dear Sir,-I have seen Secor. He says that he only contemplated speaking to Langley, if you had no objection, but to go no further. That he did not suppose you mderstood or thought or expected him to transfer to anybody unless for a price. That he would write to you immediately.

"You will see Purdy is going ahead for Collector. He has been recommended by both of the Genl. Committees, various ward associations, and a German meeting. Secor tells me he also has a strong letter from Van Buren, and he went to Albany last night to get testimonials from there, I suppose. If he is appointed he will fill the Custom House with a laughable assortment-good, bad, and indifferent. I am inclined to believe that he will be more thorough in turning out than we expected. Of course you understand that all his recommendations are bargained for; places are to be given to the men who get them up. If he succeeds you may rely that the dissatisfaction which his appointment will excite will be excessive. There is one way to [head?] him. That is a merchants' memorial, asking that none but a commercial man be appointed. This would do, and Havemeyer could be made Collector and Purdy Postmaster. But nothing ought to be done unless Polk is entirely straight.

"Henry, my brother, is just down, has been at Albany. Our friends are very much dissatisfied. Polk's offers to Wright and Butler are not regarded as having been made in good faith. It is supposed that he has his eye on a second term. I incline to concur in the first partially- that is, they were mere compliments-not in the second. I think Polk is as weak as dish-water, but honest. If he is really so, and could or would be wise, he should send in Havemeyer's name forthwith. I do not believe that our friends north of this can be induced to urge it. By the way, Purdy's movements to get this office are, and his appointments would 
be, a second edition of Jesse Iloyt's. This is by far the most important thing to be seen to now.

"I suppose if Bancroft is confirmed you will get on fineIy with the Renshaw business. There will be nothing to call you home in some days.

$$
\begin{gathered}
\text { "Yours truly, } \\
\text { "N. J. W. }
\end{gathered}
$$

\section{"S. J. Tilden, Esq."}

\section{TILDEN TO}

"Hudsov, March 17, $18,5$.

"MY deAr Sir,-An hour or so before I left Washington I learned of an act of my friend O'Sullivan which gave me some annoyance and which I intended at once to explain to you. I should have done so before except for a rapid current of business which hurried me here.

"You might, fairly enough, perhaps, suppose that O'S.'s act, although not instigated by me, was induced by his knowledge of nyy views. But such an inference would be unjust to me. I suppose the thing was suggested to him by two eireumstances. First, his knowledge that Mr. Croswell had, in December, proposed it to me with some urgeney, and, as (after casting about to discover his motive for a proposition which had mutil then never been presented to my own mind) I concluded to interest myself in behalf of Gov. Marcy for a Cabinet appointment, which I had at the time declined to do. Second, the arrival the night before of a gentleman from New York who said that my name had been diseussed-in highly respectable quarters certainlyin reference to the Collectorship. In reply to some remarks of O'S. afterwards, I said that even if that idea had been serionsly entertained I should not desire the place both from inadequacy to its physical labor and arersion to its hangman's duty at the present time. In that eomection, the other place was spoken of as free from these objections and nearly as advantageous to me personally, and in referenee to the political administration, as the Collectorship; but I said, that while the large value and light labor of it would be attractive, I should hesitate to take it, even if it were offered to me, which I ecrtainly did not expect, from reluctance to hold a mere permniary. professional office, and to surrender or so far postpone my professional pursuits. I did not, I suppose, decide the question, because spoken of 
casually, as it was, I had no thought that it was, or was ever to become, a case to be deeided.

"The moment I learned what O'S. had done, I told him that it was wrong-that you and Mr. V. B. ought, in no case, to make any recommendations until the Collectorship was settled and settled properly, beeause it might, on some pretence or claim of apportionment between the different sections of the party, embarrass that case. I should have written on my way back to that effect had not Gen. Dix, whom I saw just as I was starting, told me he harl done so.

Aside from this, I considered the question a balaneed one, which I could not decide in favor of acceptance without some consideration and advice. Under no eireumstances which I now contemplate could I present myself as an applicant for a place of this description. I did not know that after what has occurred you and Mr. V. B. would intermeddle at all in such matters."

\section{GOVERNOR WRIGITT TO TILDEN}

"Albany, May 1, 1845.

"Mr denr Sir,-Your note of the 26. ult. was duly reed. and I will attempt to give you a brief reply to it.

"The pardon of Honoria Shepherd was granted upon the exclusive application of the Inspectors and Keepers of the Prison, upon the ground that she was effectually reformed, and that longer confinement would be injurious, and not benefieial. Miss Bruce, one of the Assistant Matrons of the prison, eame up in person to get the pardon, and said her health compelled her to leave the prison, that she was about to go to Illinois to reside, and that she proposed to take Honoria with her, and keep her with her in Illinois.

"I have sent copies of all the papers in this case to Judge Edmonds, who was a leading person in the application, upon whom I principally relied, and he will show them to you, if you wish to look at them. He, too, will advise about any defence of men in this case.

"Thomas Henry was pardoned upon the recommendation of the Board of Inspectors of the prison, upon the ground that he was in a confirmed consumption, was a patient in the Hospital, a constant expense, and must remain so while he lived, and that he had friends who were willing to receive, nurse, and take care of him, if pardoned. 
This was a voluntary report of the Board of Inspectors, embracing the report of the Surgeon upon 13 permanent invalid Conviets, only two of whom were known to have friends able or willing to take and take eare of them, and those the insprectors recommended for pardons, considering it inhumane to ask pardons for the others to turn them ont sick and without home, or friends. I. Parsons of your eity is the father-in-law of Henry, and takes him to take care of him. Parsons is a Ship joiner and Spar maker, and his dangliter, the wife of Henry, who cane for the pardon, has a highly respectable appearance.

"The pardon of George Potter was granted upon the application of William F. Godfrey of your City, who gave his address to me as No. 94 Grove Street. He brought a letter of introduction to Julge Edmonds, speaking of him as his neighbor, referring' to his business and saying 'I beg to say that you can fully rely upon his representations in the matter.'

"Gorlfrey presented a petition numerous and respectably signed, representing Potter, though guilty, as the dupe of old offenders, the offence for which he was convicted as his first offence, and him as very penitent and subdued, and earnestly praying his pardon.

"Potter was arrested on fresh pursuit, on the charge of picking a pocket in Broadway, and the report of the testimony showed that he was one of 4 or 5 who must have committed the felony. One witness was very positive that Potter took the pocket book, but another witness testified that le arrested Potter, that he kept his cye upon him from the time he started to run, and that, upon search, no pocket book, or money, was found upon him. Yet that he was principal or accessory, there is no donlit.

"A Icttor from .Tames M. Smith Jr., Attorney for Potter on his trial, says Potter always avowed that he did not pick the pocket, and expresses the belief that, though guilty, he was the dupe of others.

"A letter" from the Keeper of the Prison says "Potter has conducted rery well, since he has been an inmate of this prison, and he appears to show deep contrition for his "crime" and degradation; but he is a man of peenliar temperament, which renders it extrenely difficult to judge, with any degree of certainty, the true state of his feelings.'

"This is a brief sketch of the paper case presented. Mr. 
Godfrey assumed to speak of Potter from personal knowledge, and said he came to this comtry from England, some rear and a half ago, a roung man, with a wife and two or three children, and with $\$ 15,000$ in eash; that he fell into the company of some English blacklegs in New York, who induced him to gamble, drink, and carouse with them; until they stripped him of his money, and vitiated his habits, and rendered him desperate from want, when they commenced to initiate him into the art and mysteries of picking pockets; that in his first attempt he was canght and convicted, while the real rogues and the booty escaped; that his friends in England had been kept in ignorance of his course and his fate; that they were wealthy and respectable; that friends in New York had sent his wife and children to them, instructing her not to tell of his condition; and that they were satisfied his disgrace and punishment had prepared him, if pardoned and sent to them, to pursue a different and an honest and respectable course, and they only asked a pardon conditioned that he should leave the country, never to return to it.

"Confiding in these representations of Mr. Godfrey, I granted the pardon with such a condition, and I now suppose Potter sailed for England either on the 15th or 20th of April.

"Since I have seen the strictures in the newspapers upon this case, I have been very fearful that I was imposed upon by $M r$. Godfrey, and especially as he has not come forward either to justify, or excuse, my act. I did act principally upon his representations, miler Mr. Edmond's endorsement of him, and I shonld, at the least, have required him to put those statements upon paper, and made them upon his oath. I did neither.

"Now as to the matter of explanation and defense, I have felt in no haste, because I am sensible that I may deserve some castigation for having been too yielding in the first and last of these cases, and I have endeavored to school myself neither to wince, nor to be made sour by fault finding, which I am conscious I deserve, but to try to be improved and made better by it. If I were to make a defence for myself I should make about the substance of these remarks and this Confession a preface to it, and yet it might not be either very graceful, or very wise.

"This matter of pardons is the most troublesome to me 32 
of anything I yet find comnected with my troublesome office. The applications will, I think, average from 3 to 5 per day, from the day I took the oath of office. My predecessol left an enolmons legaey of undecided cases, and several with promises of pardons after specifie periods, which are oceasionally falling in, and this has greatly inereased my labor.

"I do not intend to exercise this fearful power carelessly, or loosely, and yet I feel daily that I am in danger of doing it. I find that Courts, and Judges, and Jurors, and District Attorneys, sign with some of the facility which attends applications for office, and that the officers of the prison are also sometinnes under the influence of the amiable weakness, so that there is no standard by which I can govern my action, and it is probably impossible to avoid oceasional impositions.

"I thank you most sinecrely for your friendly care, manifested by rour note, and will now leave these eases with you, and IIr. O'Sullivan, with whom I had a hasty verbal conrersation about them yesterday.

"Will you do me the faror to read this hasty letter to my friend Judge Vanderpoel, and say to him that I should have written it to him, if $\mathrm{I}$ had not preferred to trouble yon with it, that I thank him most earnestly for his letter to Mr. Yan Buren, and have intended to write him daily, since I saw that letter, but lave not been able to find the time; and that, while I will hold this as the necessary answer from me to the part of it touching pardons, I will soon write him a satisfactory reply to the personal portions of it, for which I also thank him, as he is one of the last men I would have intentionally wounded by a careless, and what was intended to be a jocose remark.

$$
\begin{aligned}
& \text { "I am Very Truly Y'rs, } \\
& \text { "Silas Vífiat." }
\end{aligned}
$$

TILDEN TO J. I. O'SILLIVAN

"Wasmington, May 31 (Sat.), 2:39 P.M., 1S45.

"Mr dear O'S.,-At the levee last evening which $\mathrm{I}$ attended for the purpose, I made an appointment with the Pres, and am now wating in the War for the Cabinet to disperse.

"In the aftermoon T had seen Ritchie for a few moments, and made an engagement with him. I had a considerable 
talk with Seth Barton at the levee and with Tom Green at breakfast. All of them introdnced the subject of the Collectorship, and all of them especially warned me against imprudence or menace in the interview which they seem to assume I am to have with the Pres.-all tell me he is very sensitive to the idea of compulsion - and that the greatest obstacle we have is the indiscretion of some of us or of those who favor us. They all are exceedingly afraid that they may be thought to be afraid, which shows, I suppose, that they are only calmly conscions of their own comrage. But only think of it-such admonitions to me! the very incarnation of Falstaffian valor!

"I replied to Ritchie's eaution-which was the first I received; and which was given when I was talking witli some decision, with great dignity. I ought to have thanked him for its good intention while I intimated that it was superfluous-I told him that I did not come here to forget what was due to Mr. Polk or what was due to myself; I had no design to obtrudê upon the President; I had no personal interest in the question about Van Ness or any solicitude except as it shonld affect the party and the administration; my only doubt was whether I should seek an interview on the subject; I was willing to state facts, make explanations, expose the whole truth, if the President desired to hear it, respectfully but frankly; the administration was mainly interested in coming to a right decision. We had no idea of hostility to it if it was faithful to our principles-the only question was whether it was to assail us. All we asked of it was to let us alone. Our polities were now in excellent condition. We conld take care of the Whigs and Conservatives together if the administration would not systematically embarrass us, and I rather thought we conld if it did. But we thought we were entitled to an amnesty from our friends at least while we were so busy with our enemies. The old gentleman seemed greatly mystified, but I promised to explain hereafter.

"(Confidential.)

"Sund. Morn.

"I was not able to send my letter yesterday, and now add a word. I had an interview with the President yesterday. I ran over the case of Van Ness pretty freely. He replied at considerable length, ascribing the delay in his 
removal to the improper manner in which it had been demanded. The did not say, but implied that he had never intended not to renove him; made no defence or argument on the question of its propricty; merely exeused the delay. Mr. Butler, he said, had written to him that it would do no harm to retain him until the year expired, if it were immediately announced that a particular man would then be appointed. Ile complained bitterly of the attempts to intimidate and coeree him - talking magnificently about being himself President and the locum tenen for nobody; said that in his own time, perhaps Monday, perhaps afterwards, Van Ness should be removed, but swore with that terrible oath, "if the heavens and the earth come together," by which Ritchie and Green and Barton had suceessively warned me he miglit refuse if a misehance word of mine should chafe his angry mood, that he would not appoint Coddington. He should seleet a man, he said, who would he received with applanse throughout the State; on his own judgment, whom he knew and had served with. Who that man was he did not say and I did not inquire, though I did express myself with some freedom as to what the man should do. Probably the question may now be deemed settled; for you remember he employed the same planetary concussion to illustrate the fixed imevocable fate by which Marcy was to represent New York in the Cabinet. His solemu form of fiat, I suppose, answer's as the "By the Eternal" of the younger Hickory, and, being partly of earth and partly of heaven, is undombtedly of an improved quality of imaginary thunder. Still it did not shake my nerves, as a lady's displeasure might. I took it quietly, and talked occasionally as I had a chance, not so fully on all points as I wished, or "mean, if an opportunity comes mnsought; but, although I was conscious of having exposed nuyself to a part of a very respectable performance for the benefit of the rebellious Butler, Dix, and O'Sullivan, in which, perhaps, I might lose a little when it came to be privately repeated to the Cabinet and confidants, I thought that, nevertheless, I should not be justified in converting faree into tragedy. So I behaved well and was myself well treated. I inquired what was the 'intimidation' and 'coercion' referred to, and I helieve was not vory definitoly answered. 'The only specification I got was letters from three - not more, he said, than three persons, whose names, he said, he would 
not tell me-who might never know about it themselves, whom he could not answer without getting into a correspondence inconsistent with his dignity, who might not be aware of the expressions they had ineautionsly and rashly used. Your letter to Bancroft was distinctly alluded to as, among other offences, alleging 'violated pledges.' I expressed great doubts whether its contents had not been exaggerated, and when he said he had not seen it, and it was not intended for him, advised him to get it and read it. The warmth of these communications I vindicated as true representations of public feeling, expressed in honest freedom; though this part of the subject came up when the interview was forced to a close, and I conld not do full justice. Some explanations, which it was not prudent to make in the danger of exoneration, I have since made to his intimates with kindness but clearness and coldness, and shall to him if eireumstances solicit. Am not I a lucky fellow? Soothed all day by the fiery Southerns, and then sitting quietly, as in a summer shower, when the storm is beating fiercely on those imprudent young men, Butler, Dix, O'Sullivan-even, while refreshing myself, putting up my umbrella to protect them! I only lalked treason.

"He felt deeply the warm letter of his old friend Hoffman-an honest man. He would swear by him, live by him, die by him. I added Mr. H. was a true-hearted man-he was the last man almost from whom I parted; I had a long conversation with him. He fully concurred in the indispensable necessity of removing $\mathrm{Yan}$ Ness-in the earnest and strong convictions expressed by the others on that subject. The Pr. replied not. I think it was he that told me, and then that there had been letters saying that Hoffman would make his own aceptance conditional on V. N.'s removal. No, it was Cave Johnson afterwards.

"The President expressed great sorrow that he could not see Silas Wright for an hour and have his advice. As to what, I did not certainly understand."

\section{JOHN A. DIX TO TILDEN}

"Private.

East Hampton, June 21, $18,15$.

"My DEAr SIR,- I wrote to you some time ago in relation to the N. Y. collectorship. Since then the matter has been disposed of ; but in such a. way that I naturally feel a curi- 
osity to know, as far as it is proper that I should, the gromol taken by the President in declining to appoint Mr. Coddington. I have seen a letter designed as a justifieation of the Cabinet in the matter; but there is no allusion in it to assuranees given to others as well as myself that the appointment would be made in accordance with the wishes of Mr. Wright and his frienls.

" My letter, I presume, reached you; but as I have heard nothing from you in relation to your visit to Washington, it has oecurred to me that there might have been some mistake about it.

I am, Dr. Sir, Yours truly, "Joirn A. Dix."

TILDEN TO HON. CIIARLES P. BROWN

"New York, October 13, 18.5.

" Mon. Chlirles P. Brown.

"MY DE.AR Sir,-Contrary to my expectations, I find my name among those from which your convention are about to select candidates for the Assembly. I had so uniformly expressed my strong repugnance to any nomination this fall, and the groumds of it, that I did not suppose any misapprehension could exist on the subject; but I am now compelled to ask you to lay this communication before the body over which you preside.

"If the present were an oceasion of peeuliar or unusual importance, and if I flattered myself that I was capable of rendering essential service on such an oceasion - nothing, in my power and eonsistent with other obligations, would be withheld, or ever will be withheld, from the interest, the honor, or the wishes of the Demoeratic party. But I am not able to take any view of the time or of niyself which does not allow me, in this political calm, to devote mrself to professional and prirate business on which alone $\mathrm{I}$ rely for an independent livelihood, and which the more imperatively claims my attention now from the partial withdrawal of it during the great contest of last year. I, therefore, respectfully decline a nomination.

Truly Y'r Friend, "S. T. Tildenn."

As Mr. Wright had yielded very reluctantly, and more to Mr. Tilden's solicitations than probably to those of any other person, to leave the Federal Senate to be the Gov- 


\section{LETTERS AND MEMORIALS OF SAMUEL J. TILDEN}

emor of New York, he had a right to insist upon Mr. Tilden's coming to the legislature, where his services were regarded by Mr. Wright as practically indispensable to him in the discharge of his exeentive duties. Mr. Tilden therefore did not press his objection to the nomination he had declined.

\section{TILDEN TO}

“ New Yonk, November \& (1 P.M.), 1845.

"Mr dear Sir,-I thank you for your two letters, tho" I have not before been able to reply to them.

" My opinion is that our whole Assembly ticket will be elected. Col. Stevenson may be in danger, and if the current opinion were reliable would be, but I think he will suceced. As to myself, the opposition at the country meeting was inconsiderable in point of numbers; but it was the only hostile organization not counteracted by a friendly one, and I am the only candidate left off from any of the pretendedly Democratic ballots. I expect to be scratched by some of those who were hostile to Mr. Van Buren, some of those who are hostile to $\mathrm{Mr}$. Wright-the Tyler rowdies and the Walsh men."

CERTIFICATE OF MR. TILDEN'S ELECTION TO THE ASSEMBLY

"The Board of County Canvassers of the City and County of New York, having canvassed and estimated the votes given in the several election districts of said city and county at a general election held the fourth day of November, 1845, do hereby certify, determine, and declare that Alexander Stewart, Alexander Wells, Samuel J. Tilden, Jonathan D. Stevenson, John E. Develin, Gerardus Boyce, Joseph C. Albertson, Wilson Small, James H. Titus, Robert II. Ludlow, Joshua Fleet, Thomas Spofford, and John Townsend, by the greatest number of votes, were duly elected members of Assembly.

"And the said Board of County Canvassers do further" certify, determine, and declare that Samuel Osgood, by the greatest number of votes, was duly elected Register of the City and County of New York.

"Dated New York, November 21, 1845.

"B. J. Meserole,

"Alex. II. Robertson, Chairman. "Deputy County Clerk and Secretary." 


\section{JOIIN A. DIX TO TILDEN}

"Wasnixgtow, Decomber 19, $18,15$.

"Mr deAl Sin,-I sent you Fremont's report, which I presume you have ere this received.

"As to matters here, I really know as little as yourselfI mean of the views and intentions of the arministration. My intereourse with the President is ofticial; and the Seeretary of the Treasury I have not yet seen. I came here with the determination of aequiescing in whatever shonld he desired in respect to organization. I have acted on this determination. In respect to measures, I consider myself free to act according to the dictates of my judgment. Happily, the President's recommendations I cordially approve, and I shall give them my zealous support. Where we shall land is doubtful. We have an able and arloit opposition; and advantage will be taken of the minutest error in our movements. We had abundant proof of this in the matter of Cass's resolutions. I never saw two cleverer cases of genteel sparring than that of Cass by Crittenden and Allen by Clayton.

"I wish to open a correspondence with Mr. Kittell. Will you put me in the way of it?

"There are a few measures I have much at heart-the warehouse system and the branch mint at $\mathrm{X}$. Y.; the great measures, of course, take care of themselves.

"You know I shall always be happy to hear from you. I will write when I can. But I am a new nember, have everything to learn, and not half time enomgh to learn it in.

"I cannot yet say whether there is any truth in the report as to Lawrence. His name is not yet before us. Indeed, we were in executive session yesterday for the first time, and I suppose the President has been waiting for us to organize before sending in the great malss of his nominations.

$$
\begin{aligned}
& \text { "Yours truly, } \\
& \text { "Jorn A. Dix." }
\end{aligned}
$$

TILDEN TO IION. N. P. TALIMAGE

"New Yols, December 95, 18.5.

"Mr dEAR Sir, - A few days since I received a note from your brother requesting me to eall and sec him, and $\mathrm{T}$ was distressed to find that in the short interval sinee I had last 
met him his health had becone so dangerously worse. He is anxious to obtain a consulship or some other place which will give him the benefit of a climate better adapted to a chronic pulmonary discase, and a reasonable support while subjecting himself to its remedial influence. I need not say I felt a strong sympathy for him; but I feel some disability for rendering him useful aid, which $I$ will in part explain and which he and you will appreciate. Although he sustained the Democratic ticket at the late general election, and did service which I understand has been handsomely recognized by the President, his course was so little conspicuous that the impression left by his association with former events will naturally predominate in the minds of the party generals. If, therefore, the administration should regard the case in the light of mere party expediency, I do not think I could in candor towards them say what would be of much avail to him; especially as cantion in my expressions being the more necessary lest I should expose myself to be quoted not merely as offering a particular instance in regard to which I should have no hesitation if it stood alone, but as contributing to and thus sanctioning a general distinction of local patronage which is objected to, in part on the same ground on which this might be exposed to unfriendly eritieism, and which has prevailed here in the lesser appointments which most interest the mass of the party to an extent that excites very great dissatisfaction. Nor does it seem to me that formal recommendations can at all benefit your brother, nor anything which I might say in his behalf, unless the administration desired affirmatively to do something for him. If such be their real feeling - if they regard his case as one to be controlled by liberal considerations, if they recognize the strong appeal it makes to their humanity, and if they are nevertheless restrained by solicitude as to how the appointment would be reeeived by their political friends here - it is possible that I may be of some little service to him, in the only contingency in which it seems to me any service can be efficient. The object of my letter is to assure you that if the administration take favorable views of the matter, as I hope and trust they may, I shall be ready to do what $I$ can to cause the appointment to be well received by the party here; and that such, I believe, will be the general disposition of those of our friends to whom the circumstances are made known. The only hesi- 
tation I have in saying this is lest it may be assuming in me; but if you think it will do your brother any good, you may communicate it for that purpose. I did not venture to write to anybody other than yourself lest, in my ignorance of the state of feeling on which my letter might fall, and however guarded my language might be, I should unwittingly do harm, which, however frankly I may write to you, I shall avoid, even if I fail to do good.

"With the best wishes for the suceess of this object and your welfare, Truly y'rs, "S. J. Tildene."

The Albany Argus, sinee the election of President Polk, had become the organ and an extreme partisan of the soealled IIunker party and champion of the policy of the Slavery Extensionists. One of the eonsequences was the establishment of the Atlas at Albany by the friends of Van Buren and Wright. The Argus was eondueted by Edwin Croswell, a then veteran joumalist, and the Atlas by a Mr. Van Dyke, assisted by a very elever voung man of Irish extraction named Cassidy. These two prints registered the stages of the ineffectual struggle of the Van Buren and Wright party with the administration at Washington, a specimen of which is diselosed in the following eorrespondence between Mr. Croswell, Mr. Tilden, and Joln Van Buren, a gifted son of the ex-President Van Buren, and then rapidly becoming a conspicuous figure in national polities.

\section{E. CROSWELI, TO TILI)EN}

“Albany, January 26, 18:,6.

"Dear Sir,-I am informed by a member of the Legislature, whose veracity I camnot question, that you stated to him that I had made a proposition in relation to a compromise of the questions of differenee between the Argus and Allas, which had been accepted by you or your friends, but which I had flown from or violated under the pretence of consulting my friends.

"Allow ne to ask whether I am to understand you as having made such a declaration.

"Very respectfully, "Yr. obt. servt., "E. CRoswell." 


\section{LETTERS AND MEMORIALS OF SAMUEL J. TILDEN}

TILDEN TO E. CROSWELL

"Albany, January 2\%, 1846.

"Mr DEAr Sir,-The inquiry which your favor of yesterday contains is so made up of statements and inferences - so very general in some respects, and so imperfect in others-that an answer to it which expresses neither more nor less than the truth must be more specific than you seem to ask.

"I understood from gentlemen whose veracity I could not question that on the Wednesday before the recent caucus you made to them a communication to this effect:

"You said that it would not do for you to make any further proposition relative to the union of the Argus and Atlas, but you invited a proposition to be made to you, the terms of which you specified as follows: That the Argus and Atlas should be united, at an appraised valuation; that the joint establishment should be owned by Messrs. French, Cassidy, and Sherman Croswell in three equal parts; that you should withdraw from the concern; that Messrs. Cassidy and Sherman Croswell should be candidates for State printers; and that the emoluments of that office, if it were conferred upon them, should belong to the joint establishment.

"This proposition, you said, would be entirely acceptable to yourself, and you expressed great confidence that you could induce your friends in the Senate to confirm it. In that erent, the bill purporting to abolish the office of State Printer, of which you expressed decided disapprobation, would, you hoped, be postponed or greatly modified or defeated, and harmony, as you thought, restored to the Republican party. The result of your efforts was to be communicated to those from whom the proposition was in form to emanate before the assembling of the caucus. Your suggestion was in all respects adopted and followed by them.

"Deriving from these facts, as well as from the interviews which you had sought with me on the subject, strong hopes that an arrangement satisfactory to all parties, consistent with public duty, and conducive to the interests and the honor of the Democratic cause, would be effected; and having reason to believe that more of the radical Democrats of the Assembly and all those of the Senate would assent to the union of the two papers (being first convinced that 
the adrocacy of somel Democratic doctrines would be essentially secured-of which fact you were, after consultation with them, arlvised-you may inagine my surprise when, half an hour before the caucus met, I learned that, although twenty-four hours had elapsed, you had not even communieated with several of your prominent friends in the Senate; had not seen your partner and relative, who is a member of your own fanily; had failed to keep your appointments; and, when sent for, at my instance, who was still unwilling to impute a design to cvade, were unprepared to close the negotiation, to make any definite arrangement, or even a proposition. Attended as this failure was by the foreing through the Senate, at an extra session, held in the mean time, by your friends, of the bill you disapproved, and followed, as it has since been by your adrocacy in the Argus of that bilb I am forced, in the absence of all explanation, to entertain more distrust than I remember having expressed, or wish to express, of a negotiation in which I engaged at your solicitation.

"In regard to the particular language which your letter ascribes to me, I have no recollection of having used it, nor does it, in the way you have stated it, remind me of any conversation out of which the information you repeat to me may have originated. Nor does it seem to me in substance correct, so far as it may be construed to imply much of a direct personal communication between, rou and me after the first stage of the negotiation; or any' effort to ' compromise the questions of difference between the Argus and Atlas,' further than to mite these two papers, which I was sincerely anxious to bring about, and after the intinations from you did actively recommend to my associate Democrats of the $\Lambda$ ssembly, while I left them and myself at perfect liberty to act according to our individual judgments and eonsciences on any questions of reform in regard to the office or the functions of the State Printer. But that I may not have adverted to the distinction, if there be any in substance, between your making a proposition and suggesting one to be made to you which you declared heforehand woukd be entirely acceptable to you, and may have spoken in general terms of the proposition as yours as well as that of those you represent, is very possible; and that T may have casually expressed the sentiments which the facts above stated necessarily exeited, in regard to the part rou bore in the trans- 
action is possible, though I do not remember having done so, and I am sure if $I$ have not the forbearance is to be imputed solely to reluctance with which I have put an unfavorable construction upon your conduct.

"If there is any explanation to be offered I should be glad to hear it, and to learn if I have even in thought done you the least injustice.

"With great respect, your obdt. servt., "S. J. Tilden."

\section{JOHN VAN BUREN TO EDWIN CROSWELL}

"(Circa January 2\%, 1846.)

"Dear Sir,-I have recd. your favor of the 26th inst. making certain inquiries of me, and I very cheerfully state my recollections in regard to them.

"On Wednesday, before the late caucus, I learned from gentlemen of undoubted veracity that you had made to them the following communication: You said that you would make no further propositions in reference to the union of the Argus and Atlas, but you invited a proposition to be made to you, which you said would be entirely acceptable to yourself, and expressed great confidence that your friends in the Senate would be induced by you to confirm it. In that event the bill to abolish the office of State Printer, pending in the Senate, of which you expressed your decided disapprobation, you hoped would be postponed and greatly modified or defeated, and harmony restored to the Republican party. The result of your efforts was to be communicated to those who were to make the proposition prior to the assembling of the caucus. The precise offer that you invited was made to you on IVedy. aftn.

"Hearing these facts, and having strong hopes that an amicable arrangement satisfactory to all parties would be brought about thro' your exertions, and having reason to believe that the great mass of the radical Democrats of the Assembly and all those in the Senate approved of the union of the two papers on the terms now suggested, which they thought secured the advocacy of sound principles, you may imagine my surprise on being informed, a half-honr before the caucus met, that altho' more than 24 hours had intervened, you had not even communicated with several of your personal friends in the Senate, had not been able to see your 
own partner and cousin, who is a member of your family, failed to keep yr. appointments, was fouml with difficulty, and was not prepared when found to make any definite arrangement or even proposition. Attended as this failure on your part was by the foreing thro' the Senate by your friends of the bill you disilpproved, and followed by strong and indignant denumeiations the next morning in the eolumns of the Argus of sereral leading Demoerats in the Senate, and warm adrocacy of the same bill, I was forced, in the absence of all explanation, to conclude that if you had not acted in bad faitl you had certainly trifled in a most extraordinary manner with a subject I considered of great importance.

"Under these circumstances, I claim credit for myself in speaking of rour conduct with great forbearance, and have no recollection of using the language you attribute to me in your note, tho', as I did not adrert to the distinction (if there be any in substance) between your making a proposition and inviting one to be made to you, which you declared beforchand would be acceptable to you, I have doubtless spoken freely of the part you bore in the transaction as inexplicable and censurable.

"I shall be happy to hear any explanation you have to make, and glad to know if I lave unintentionally, even in thought, done you injustice."

CERTIFICATE OF TIE ELECTION OF MR. TILDEN AND OTIERS TO TIIE CONVENTION ORDERED TO REVISE TIIE CONSTITUTION ON THL STATE OF NEW YORK IN 1846

"The Board of County Canvassers of the City and County of Now York, having canvassed and estimated the votes given in the several election districts of said eity and county at a general election held the 14th day of April, 1846, do hereby certify, determine, and declare that Charles O'Connor, Henry Nicoll, Samuel J. Tilden, Benjamin F. Cornell, Camplell P. White, Alexander F. Vache, Lorenzo B. Shepard, John A. Kenuedy, John L. Stephens, Robert II. Morris, William S. Concly, l)avirl R. Floyd Jones, Solomon Townsend, John II. IInnt, Stcphen Allen, and George S. Mann, by the greatest number of rotes, were duly eleeted 'Delegates to meet in convention for' the purpose of con- 
sidering the Constitution of this State, and to make such alterations in the same as the rights of the people demand and as they may deem proper, under an act of the Legislature of the State of New York, entitled, "An act recommending a convention of the people of this State." Passed May 13, 1845.'

“Dated May 11, 1846.

$$
\begin{aligned}
& \text { "Egbert Benson, } \\
& \text { "J Chairman. } \\
& \text { "County Clerk, Secretary." }
\end{aligned}
$$

\section{N. J. WATERBURY TO TILDEN}

"New Yокк, August 28, $18: 6$.

"Mr dear Sir,-Mr. Guion* visits Albany at my request to see you and Kennedy, and through you to consult with others for the purpose of finally ascertaining whether anything is to be done to sustain the Nows. If anything is to be done it has got to be made available for Monday. Unless some money is then obtained, that will be the last number of the paper issued. I have the same opinion as before expressed in relation to the great importance of sustaining the paper until after the election at least; and I have stated to you the only plan I know of for doing so. Gen. Spinner suggests that John G. Floyd be induced to take the paper. With $\$ 3000$ we can sustain the paper until January 1st. With $\$ 2000$ until November. If it should go down before the election it will injure us greatly. Mr. Guion goes up at my earnest request, and not that he has any further personal solicitude about the matter than you and me and all our friends feel.

"In liaste, yours very truly, " Nं. J. Waterbury."

"New York, Sep. S, 1846. "6 1-2 O'clk. I'.M.

"Denr Tilden,-The long agony is over-the Morning News is dead-dead; no time to say more.

$$
\text { "Truly "Y's, }
$$

* The business manager of the Daily Ncuss. 
The public interest in the history of the Morning News, of which Mr. Tilden and John L. O'Sullivan were joint proprietors, may be said to lave teminated with the exeention of the docment of which the following is a draft, found among Mr. 'Tilden's papers.

\section{CONDITIONS ON WIICII TILDEN RETIRED FROM TIIE "MORNING NEWS"}

"S. J. T. retires-surrenders all his interest-is indemnified against its outstanding liabilities.

"J. L. O'S. and II. G. I. (H. G. Langhey) rearrange their proportion of ownership. Hereafter to own equally. The difference of eapital to be equalled by eredits to II. G. L., the necessary amount on his "advanees, existing or prospective.

"II. G. L. contracts to devote himself faithfully to the business and interests of the paper - to conduct with the utmost energy and fidelity the procuring of alvertisers.

"Failing to do this, he is to retire, giving O'S. all reasonable facility to substitute some other persons on reasonable terms of sale. All disputes and differences of opinion as to these stipulations to be left to the decision of -

The trimmph of the pro-slavery party in the election of Mr. Polk resulted in the revolt of Texas from Mexico, her annexation to the United States, and a war with Mexico.

At the expiration of his term, Governor Wright was renominated almost unanimously. If elected, nothing in the future appeared more certain than that he would lave been Mr. Polk's suceessor in the Presideney. 'The reversion of the Chief Magistracy to such a formidable opponent of slavery extension as Governor Wright, who conld neitlier, he eorrupted nor eajoled, was then regarded at Washington as a peril, to avoid which no sacrifice was too great. The magnitude of the sacrifice of Mr. Wright was as correctly appreciated at Washington, and by the very men who were to offer it up as a propitiation to the demon of slavery, as at Alhany; hut to the short-sighted vision of the statesmen then in the ascendant at the national appital the political su- 
premacy of the slave-holding States was to be maintained at any price.

The influence of the Federal government was, therefore, all turned against Mr. Wright at the Gubernatorial election in 1847 , and it proved to be suffieient to give a majority of some eleven thousand to John Young, the candidate of the Whigs.

Mr. Wright, at the expiration of his term, returned to his home in St. Lawrence County, consoled by the reflection that the evil eonsequences of taking him from the Senate and making him a party to the faction fights in New York had resulted as he had predicted-in disaster to the party and in his own political destruction. He died within nine montlis from his retirement.

The annexation of Texas and the war with Mexico which ensued resulted in the acquisition of vast territories, sooner or later to be organized into States, to be consecrated to freedom or to slavery. To open these States to slavery and reinforce the slave representation in Congress, it had become necessary to paralyze the Democratic party in New York.

The first steps towards this end had been taken in the defeat of Mr. Van Buren's renomination for the Presidency, and putting a Southern man in his place. The second had been taken in the defeat of Governor Wright's re-election in 1847 ; the third, yet to be taken, was to deprive the Democracy of New York of its legitimate influence in Congress and the next Demoeratic national convention.

In this scheme the administration was entirely successful. At the commencement of President's Polk's administration the Democratic party was completely in the ascendant in New York. It had elected its Governor and Lieutenant-Governor; it had a majority in both branches of the Legislature, and a majority of the delegation in Congress. At the expiration of two years its Chief Magistrate was a Whig, and its Congressional delegation was reduced to a meagre minority. The following year the whole legislative power of the State was transferred to the Whigs by an overwhelming majority, and the schism in the party, 
eneouraged by the bestowal of all the patronage of the Federal government upon the "Ilunkers," had becone irreparable.*

$$
\begin{aligned}
& \text { JOIIN A. DIX† TO S. J. TILDEN } \\
& \text { "WASIIINGtox, January } 2,184 \%
\end{aligned}
$$

"MY DEar Sin,-Yours is received. I do not know whether I ean have any influence in the matter referred to, but will bear your wishes in mind.

"Everything here is in miserable condition. I do not know whether Mexico will make peace, but I am sure she would not if she knew what a state we are in. Still I hope for the best. Mr. Polk is in a minority in both Honses. Il is most disinterested and reliable supporters are the friends of those he has treated worst. I am sick of the whole concern, and, most of all, of the miserable manneuvring for high place, which is beginning to show itself.

"If we had a discreet and energetic leader in Mexico, I think we might bring the war to a close. But the lientenantgeneral has been slain, and with hin I think dies all prospect of success by arms or diplomacy. Our only ehance is in luck, and Mr. Polk is so fortunate in getting out of serapes just when he is most straitened that I am inclined to bet on him yet.

$$
\begin{aligned}
& \text { "Yours in haste, } \\
& \text { "Join A. Dix." }
\end{aligned}
$$

\section{THE FIRST GUN FOR FREE SOIT,}

A pril, 18 /8.

A $\mathrm{T}$ the threshold of the Free-soil revolt of 1848 , exPresident Van Buren, who was spending the winter in lodgings at .Julian's Hotel in Washington Place, New York, said one day to Mrr. Tilden, as he handed him a roll of manuseript: "If you wish to be immortal, take this home with you, complete it, revise it, put it into proper shape, and give it to the public."

Mr. Tilden replied that he had not the slightest wish to be immortal by any proeess that would impose upon him at

* Life of Tilden, Vol. T., p. 116-117.

$\dagger$ At this time a member of the Unitcd States Senate from New York. 
that time any more labor; but he consented to take the manuscript down to the residence of the ex-President's son, John Van Buren, who then resided in White Street, and he agreed that if John would do half of the work he would do the other half. John did agree, and a few days after the interview referred to, Tilden and John met at the ex-President's lodgings to report.

Mr. Van Buren opened the subject by asking what they had done with Niagara Falls. This referred to a somewhat ambiguous metaphor which had found its way into the exPresident's manuseript. "We have struck that out," was the reply. He laughed, as if rather relieved at having an unpleasant duty discharged by other hands, while they went on to read the result of their joint labors.

After the address had received the combined approval of each party to its composition, the next question was how to get it before the public. After discussing various plans, they finally deeided to issue it as an address of the Democratic members of the Legislature. Accordingly, on the 12th of April, Senator John G. Floyd, from the committee of Democratic members of the Legislature to prepare and report an address, read the paper to his colleagues, by whom it was unanimously adopted. This memorable and epochal document was given at length in the Public Writings and Speeches of Tilden, Vol. II., page 537. This address deserves to be regarded as the corner-stone of the "Free-soil" party, as distinguished from the party of unconditional abolition.

\section{S. P. CHASE ${ }^{*}$ TO JOHN VAN BUREN}

“Columbus, June 19, 1848.

" $\mathrm{Mr}$ dear Sir,-Many of our Free-Territory men in this quarter are in doubt as to the course which the New York Democracy intend to pursue in reference to the Buffalo convention. Will they be represented in it? Will they coneur in the nominations made by it? If Judge McLean can

* A resident of Ohio, the following year was elected to the United States Senate, subsequently became War Seeretary of the Treasury under Lincoln, and died Chief Justice of the Supreme Court of the United States. 
be induced to accept a nomination for the Vice-Presideney, in eomnection with Mr. Van Buren for the Presideney, will they eordially accept it? If the convention, on mature deliberation, should think it expedient to nominate Judge MeLean for the Presidency and Col. Samuel Young or Bradford R. Wood or yourself for the Vice-Presidency, would the New York Democracy concur in that nomination? There is a strong disposition, also, in the West to drop the older politicians altogether and take younger men, who better represent the spirit of the time. One of the best and ablest Democrats in the State, I mean Edwin M. Stanton, said to me to-day that if Jolm Van Buren should be the nominee of the Buffalo convention he would roll up his sleeves and go to work till the election for the ticket; and I am sure that to all the young Demoerats and all the young Whigs in the State your name would be more aceptable than your father's. Suppose the convention should be animated by this spirit and nominate men of this generation, would the New York Democracy conemr?

"I put these questions to indicate the various phases which the movement may assume. My own opinion is that, under existing eireumstances, the best possible nomination for the Presidency has been made at Utica, provided the name of John McLean ean be associated with it. Whether it can be is, as yet, in donbt, though I fear the donbt will be resolved against my wish. If it eannot be, we have no man in the West whose name on the ticket would be altogether unexeeptionable. If Judge MeLean should consent to allow his name to be used, the ticket wonld undonbtedly sweep Ohio, and wonld gain immense accessions of strength throughout the West. I firmly believe that the nominees may, in that event, be elected this year. It would be, to be sure, sacrificing a good deal on the part of Judge McLean, so long prominent in the regards of the people as a candidate for the first office, to aceept a nomination for the second ; and the bitterness with which he conld be assailed by the slaveholders and their allies would exeed greatly that which is now manifested towards your father. Nothing but a strong sense of personal duty, and a deep interest in the suceess of the movement (and he avows that interest openly), will prevail on him to consent, and, I fear, he will not feel that chuty absolutely reguires the step. It is probable that he would regard an offer of a nomination for the 
first office differently. He would then be the recognized head or representative of the movement, and would feel the abuse directed against him, as levelled chiefly at the cause. And I think he would represent the movement almost exactly as Silas Wright would have done if living. I regard him as more nearly resembling Silas Wright in the general character of his views on public questions than any living public man. While, therefore, I repeat that if we can have Judge McLean's name for the Vice-Presidency I would rather take the ticket as it would then stand-Martin Van Buren and John McLean-than any other, you will not wonder that I regret that the action of the convention at Utica has interposed an obstacle to a different arrangement. Whether the obstacle is insuperable you are a far better judge than I am. If it be, then, we must take the Utica nomination, supply the Vice-Presidential vacancy and make the best fight we can.

"You will have observed the difficulty suggested by the National Era growing out of the expressions in your father's letter, in relation to slavery in the District of Columbia; and you are doubtless aware that all that part of the letter in reference to the course of his administration on the subject of slavery is very distasteful to almost all anti-slavery men, whether TWhig, Democratic, or Liberty.

"I wish that part of the letter could have been omitted. It does no good to revive the past. Our business is with the present and the future. Your remarks in your speech at Genesee on the 20th of Jinne are full of truth. The freeTerritories question, in discussion, must bring up the whole slavery question inevitably. Our contest is with the slave power, and it will break us down unless we break it down. The people will not stop with the exclusion of slavery from Territories: they will demand its complete denationalization. Now many understand Mr. Van Buren's letter, so far as it tonches upon slavery in the District, as a reiteration of his pledge to veto a bill for the abolition of slavery there if enacted by Congress. I do not myself so understand it. I cannot believe that at the present day and under present cireumstanees, when a strong anti-slavery sentiment exists in Maryland and Virginia, which would be vastly strengthened by such a measure-so strengthened, indeed, that those States would by it be converted into free Territory Statesthat he would interpose the slightest obstacle to its adoption. 
I cannot doubt that, on the contrary, he would give it every faror consistent with the proper discharge of his function as President.

"So many, however, take a different view from mine that it is highly desirable, in the event that MI. Van Buren is to be the nominee of the Buffalo convention, to have all doubt on this matter removed, so that he may be received and understood everywhere as a true representative of the movement.

"The uprising in this State exceeds all expectation, and if we only ean present a proper ticket at Buffalo we shall have the best chance of earrying the State. But the effect of the movement is different here from its effect in New York. The question in this State will be between the independent nominee and Cass. Taylor is, with us, entirely out of the question. The people reject him, and the politicians support him, when they do at all, doubtingly and without enthusiasm. The Cass men are more active and with better hopes. In conversation with Judge Wood yesterday, or the day before, I remarked to him that I was a little surprised, after reading of the interview between himself, Cass, and the people at Cleveland, to hear of his advoeating on the stump the claims of Cass, as a Wilmot proviso man. 'Oh,' says the judge, 'He is for the proviso as much as any of us.' 'Do you mean to say, then, that the Nicholson letter was designed to cheat the South and get the nomination?' I asked. 'D-n them,' said he, 'it is their turn to be cheated.' This is a common argument among the Cass men; and as there is something like retribution in kind indicated by it, it don't take very badly among the people.

"I shall be very glad to hear from you, and to be advised of the views of yourself and others, to whom you may show this, as to what is best to be done and the best mode of doing it.

Yours very truly, "S. P. Cinase.

"P. S.-Did you or Mr. Preston King receive a telegraphic despatch, at Utica, stating the action of our people's convention, which adjoumed the day before your session commeneed? We, Mr. Vaughan and mrself, sent one on the evening of the 21st, and it should have reached you on the morning of the $22 \mathrm{~d}$ at the latest. We shall be glad to know whether it reached you at all, and, if so, when." 


\section{LETTERS AND MEMORIALS OF SAMUEL J. TILDEN}

TILDEN TO S. P. CIIASE

"New York, July, 1848.

" MY DEAR SrR,-Your letter came here in the absence of Mr. J. Van Buren, which still continues, and it has been handed to me by Mr. Bryant, with a request that I would answer it. I desire to do so with perfect candor, and with as much accuracy as I can in regard to questions which depend upon the concurring action of numerous individuals composing a large party.

"As to your inquiry whether the Barnburners of New York will be represented in the Buffalo convention, I can only say that so far as representation consists in the presence of persons who will be asked to consult with the members of that body and inform them of the views of the Democracy, there will be no want of it. But representation of the formal and authoritative character which is usual in the delegated conventions of organized parties will not be possible, either from the nature of the convention itself or the circumstances in which the Democracy of this State are placed. The convention professes to be merely a mass convention, and docs not aim at the indispensable characteristics of a delegated body-among which is a proportionate representation of ascertained constituents, whose numbers and relations are already known; but it will be simply a voluntary assemblage of individuals, whose relations to each other are to be for the first time established. Nor is there any person to act authoritatively for the Democracy of this State, as an organized body, until the meeting of the Utica convention on the 13th of Sept.

"But all this is not deemed to be a matter of much consequence. The Buffalo convention must act with spontaneous harmony or it will fail of its objects, and the spirit of the people and the circumstances of the occasion will be likely to make it very independent of forms. If it acts with wisdom, the Utica convention will doubtless concur in its nomination for the Vice-Presidency.

"As to the Presidency, it will not, under any circumstances, be practicable to change the position of the Dcmocracy of this State. Their convictions on this subject would be irresistible, whatever might be the desires of leading men. Nominated, as.Mr. Van Buren was, against his wishes, and because he was believed to be the strongest can- 
didate with nearly all to whom they had a right to look for smpport, and aequiescing, as he did, on the gromel that his old companions and their descendants had a right to his name to strengthen then in maintaining their characters and eanse amid the perils and diflienlties which surrounded them, it wonld not be decent towards him, now that more than they at first hoped is sure to be accomplished, to seck another representative. A still stronger consideration wonld be the bad faith of such a procedure towards large number's of men and influential presses which have heen drawn into our support of Mr. V. B.'s name. Another would be the great impolicy of changing front on the eve of battle, when the public mind has adapted itself and individuals have found relations with reference to the candidate. And another would be the conviction that in this State at least his name is far the strongest that can be presented with reference to practicalle accessions to the cause. Of course this may be assumed to be the fact among the Democrats from whom our strength must mainly come-and the aid we have derived from it has been very great-while those Whigs who are disposed to go with us prefer him to any other Democrat, if I may judge from their expressions to me and others before the convention of the $22 \mathrm{~d}$ of June.

"The Democracy of this State supports the cause and Mr. I an Buren, an organized party having more than fifty presses, many of which are the longest established and most influential in the State, and are organs on which perhaps the contest turns."

\section{GOVERNOR COLES TO M. VAN BUREN}

\section{"Philadelphia, October 12, $18: 9$.}

"My dess SIR, - Your very kind and flattering letter of the first instant would have been sooner acknowledged but for my having had the pleasure of having with me Mr. and Mrs. Singleton and Miss MeDnffie, and also your son, the colonel, and Angelica, and since they left me I have been so unwell as to be incapable of writing. And I am still too much indisposed to do much more than to express the gratification I derived from its perusal and to receive your commendation of my letter to Mr. Richards, which gave me the more pleasme, as I foumd my letter would disappoint him and other friends from its treating on newspaper and conmon-place topics, accessible to all, instead of giving facts and 
aneedotes not generally known, and which had become partieularly well known to me, from the deep interest I have long taken in the subject, from my residence in Illinois at the period when efforts were made to make it a slave-holding State, and from my intimate aequaintance with most of the great men of the country. But I was sensible of not being able to do justice to the information I possessed, without a reference to documents not aceessible to me at Schooleys Mountain.

"Your son Joln having requested me to send him a copy of a letter written by Mr. Jefferson to me in August, 1814, on the subject of slavery, and also a communication made by me to the National Intelligencer, and published in that paper Feb. 14, 1838, in relation to the abolition of slavery in the District of Columbia, I have since my return home from my summer excursion enclosed them to him to 91 White Street, New York, and hope he has reeeived them, as I think the republication of Mr. Jefferson's letter at this time will do much good.*

"In explanation of some parts of Mr. Jefferson's letter, I ought to add that it was written in reply to one from me, informing him of my repugnance to holding slaves, and my determination to leave Virginia unless I could see some prospeet of abolishing slavery in the State, and urging him to step forward as the leader in the great work. He showed our correspondence to many persons, and urged them to associate with me and form what he called a phalanx for bringing forward the neeessary measures to put an end to slavery. Seeing no prospect of suceess, I abandoned the State, restored to my slaves their liberty, and removed them to Illinois, where I have had the high gratification of seeing them free, happy, and prosperous.

"I have been too unwell to see and to deliver to our old friend, Mr. Short, your kind message. As soon as I am well enough to walk to his house I will do so. As I am now suffering a good deal from headache I must conclude, after repeating assuranees of $\mathrm{my}$ great respect and sineere regard.

"Martin Tan Buren, ex-President U. S."

"Enward Coles.

* The letter here referred to was brought to me by Joln Van Buren about the date of the letter here given; was published by me promptly in the New York Evening Post, and was republished by the late Paul S. Ford in his edition of the Works of Jefferson.-EDiton. 
THOMAS VAN RENSSELAER TO MARTIN VAN BUREN

"Hon. Martin Vax Buren.

“ New Yonk, Oct. 16, 19 ;s.

"Respected Sir,-Under ordinary circumstanees it would be ont of place for such an humble individual as myself to address you, but I consider that a erisis has arrived in this country which calls for the untiring exertions of every good man to eheck the spread of slavery which threatens the very existence of the institutions of the eountry, and my apology may be found in the fact that I am identified with this proscribed class. You will reeognize me as the conductor of a small newspaper in this city called the Ram's Horn, a few copies of which I have taken the liberty of nuailing to your honor.

"The approaching election I look upon as one of considerable importance to the country, and altho my paper is not a political one, yet I have thought right under existing cireumstances to advocate the nominees of the Buffalo eonvention, $*$ and try to induce the few limndred of my colored brethren in this vicinity who have votes to east them in favor of Free Soil. We have had several meetings, and, in fact, done all we could with our limited means, and I have consulted with the Free Soil men here what is our best courso to pursue, and the conclusion is to continue pubishing and operating as effieiently as we can among ourselves, and if we can obtain a little pecmiary assistance for a short time I think we can do considerable in the right direction. Can you put us in a way to have a little funds at our disposal, and thereby enable us to forward the good eause? "Respeetfully,

$$
\text { "Thos. Van Rensselaer." }
$$

\section{YAN BUREN TO S. J. TILDEN}

" Lindenwald, Oetober $18 t h$, " 8 .

"Mr DEar Sir,-As you are the nuan of business, if not the only one in our ranks, ron must not complain of the trouble I ann about to give you. The encloserl has enbarrassed me not a little. II aving been pleased with the writer's

* At this convention Martin Van Buren had been nominated by the Free-soil party for P'resident, and Charles Francis Adams for VicePresident. 
very successful reply to Mr. Gerrit Smith, which I think we read together, I feel loath to slight him altogether, and yet I can neither do what he suggests without falsifying my position or open a correspondence with him without exposing the act to perversion. I wish, therefore, you would take the trouble to send for him and explain to him my situation upon the said point. In haste, very truly yours, "M. Van Buren."

TILDEN ON MR. GREELEY, THE LEGISLATOR, AND THE SLAVERY QUESTION*

\section{[From the "Evening Post," Dec. 23, 1848.]}

"When we wrote our former articles on the bill of Mr. Douglass we had not seen the letter from Mr. Greeley which was published in Saturday's Tribune (Dec. 16, 1848). The intimation contained in that letter of his sentiments and probable course in regard to that bill if presented in its original form, would not have been allowed to pass without the animadversion which its extraordinary nature calls for, and which we shall now briefly make, not upon the impersonality which edits the Tribune, but upon Mr. Greeley, the legislator, who represents in part the people of this city in the highest councils of the nation.

"When, after having professed to consider the extension of slavery to free Territories as the question of questions involved in the late eleetion-after having for months exhorted all to treat it as far above the other objects of party association, and reproached those who did not so treat it as false to freedom-after having at first distrusted the noble band of Democrats who proclaimed their determination to maintain throughout the canvass and at the polls the sentiments which they had before professed, taunted them with the prediction that they would ultimately surrender principles to a slavish subserviency to party, and at length applauded their constancy when it could no longer be disputed; after having stigmatized as reereant to principle and duty all who should support a candidate for the Presidency not avowedly in favor of the Wilmot proviso; after having denounced General Taylor as identified in interest and association with the slave power, and probably unsound in prin-

* Mr. Greeley was at the time this article appeared in the N. Y. Evening Post a member of Congress from New York city. 
ciple on the greatest of issues; when, after having done all this, the editor of the 'Tribune, on the eve of election, announced his intention to support General 'Taylor, to vote for a man because he was available, whom he had denomneed for that very reason when nominated as an available; to vote for a num because he would beat Gen. Cass, whom he had denounced when nominated on that express ground; to rote for a man whom, after three months of nice balancing, he fomd to be a shade less objeetionable than another eandidate, because it was necessary to make a choice of evils between the nominees of the two old party organizations, no matter how wrong and dangerous the principles of both might be; thus surrendering the great question of freedom in the Territories, in the same manner and for the same reasons, for which most of the supporters of Taylor and Cass at the North professed to surrender it, and uniting with them in presenting the miserable spectacle of a number of electors sufficient to choose the President, all voting for men not representing their sentiments on a question professedly regarded by them as the most important, beeause there was no chance of electing one who did represent those sentiments; when, in a word, after all his former professions, Мrr. Greeley ended in doing precisely what the original Taylor men and the Cass men of the North did, and for preeisely the same reasons, and addressed to others precisely the same arguments which had been so long addressed to him in vain, and which he had been so long refuting, he shook deeply-very deeply-the eonfidence in his sineerity which his apparent zeal in behalf of freedom had inspired. For our part, we were inclined to take a cliaritable view of his condnet. We thought we saw him struggling in the meshes of party association, and yielding not until he harl half satisfied his own eonseience that he eould vote for Taylor as not so eertainly dcelared as Cass, and therefore not quite so ohjectionable on the great issue, and at last reconciled to himself by the general sense that it was a little better' that Taylor should he elected than Cass. We thonght we saw a painful conflict with his self-respect and his sense of consisteney-a eonsciousness that he had not chosen the nobler, even if the more expeclient, part-that he was doing at best a doubtful act against which his better nature revolted. We are disposed always to respect, in silenee, snch manifestations, and not to reproach. 


\section{LETTERS AND MEMORIALS OF SAMUEL J. TILDEN}

"But what shall we think, what shall we say, of the spirit exhibited and the sentiments expressed in the following passage of MTr. Greeley's letter, which we have read with astonishment and regret:

"'... And now to revert to the main question - the organization of the new Territories, and the allowance or disallowance of slarery therein - I have been confidently hoping for an early and peaceful adjustment of the whole vexation. The bills of which Mr. Douglass, in Senate, gave notice on reaching this city-to provide for the organization of California as a State and New Mexico as a Territorywere signs of promise. Upon the basis here suggested, it seemed to me practicable to settle the whole difficulty without farther excitement or peril. I thought we should ultimately agree to permit New Mexico, as well as California, to take the requisite steps for organizing as a State, and bring them both into the Union in the course of the next two years, leaving them free to frame their own institutions. This done, the North would be morally certain that slavery would not be tolerated in either State, and the South would save the point of honor by the almost certain defeat (in Senate) of the Wilmot proviso, which, to an established and admitted State, is confessedly inapplicable. And thus would close the grave of agitation with regard to slave territory.'

"And the letter then proceeds to say that 'the bright sky has been overcast' by the modification by which it is proposed to annex the portion of New Mexico east of the Rio Grande to Texas, which is stated as the only objection to the bill.

"The first remarkable thing in this letter is the spirit in which it speaks of the question of extending slavery to the Territories now free. If the only thing to be done was to get rid of a troublesome question, Mr. Greeley's mind would seem to be directed exactly to the object. If the writer were one of the conservatives of the Syracuse convention of 1847, who laid the Wilmot proviso on the table, or one of the Whig Dough Faces of the Philadelphia convention, who 'kicked it out' of that body, the terms in which the measure is spoken of would be very characteristic. To adjust 'the whole vexation' - 'to settle the whole difficulty without farther excitement or peril' - 'to close the grave of the 
agitation,' was precisely what they desired to do. But if there is something more to be done thin to evale this great question in order to save party arrangements from embarrassment-if it is of any importance to make freedom in the 'Territories certain instead of leaving it to chance-if the opinion, which has been so frequently and earnestly maintained by Mr. Greeley, as well as all who profess to be friends of freedom, that for this purpose an express enactment by Congress onght to be made, be not an utter inposture and frand, then we submit that the spirit mamifested in this letter is not that in which this great question should be treated.

"The second remarkable thing in the letter-and by far the most remarkable-is the mode in which it purposes to adjust 'the whole vexation.' A Territory extensive enough to make thirteen States as large as New York has been acquired; it is wholly unoceupied, exeept by a small population in a few localities. The question is, shall slavery be allowed to be established in it during its territorial condition? Neither party to the controversy regards as of practical moment the territorial condition, except as it will influence and practically control the conditions, in this respect, of the States which are to be formed out of the Territory. And it is gravely proposed at once to declare this Territory, which is in no proper situation to be formed into States, and which nobody would think of forming into a State now except for the purpose of getting rid of the neeessity of acting on this subject, to be a State. And this is called by Mr. Greeley 'settling,' instead of dodging, the question!

"Gen. Cass proposed, in his Nicholson letter, to leave to the seattered inhabitants who are to be found in some small portions of this vast region to decide the question by a territorial legislature. Mr. Greeley, in his letter, proposes to leave it to precisely the same individuals "free to frame their" own institutions' by a State legislature.

"What essential difference is there between the two plans, so far as the extension or restriction of slavery is concerned?

"Suppose that on the 3rd of March next, at the close of the session, Mr. Greeley's plan should be adopted; that on the 3rd of July a territorial legislature should be elected; and that on the $3 r d$ of September it should meet and adjust 
the 'whole vexation' Or suppose that on the 3rd of March Gen. Cass's plan should be adopted; that on the 3rd of July a State legislature should be elected; and that on the 3rd of September it should meet and decide the question.

"Would it be important whether the government were called 'State' or 'territorial,' so long as it had equal power to act on this subject, and constituents and representatives were the same, assumed their functions at the same time, in the one case as in the other? Would it affect in the slightest degree the actual extension or restriction of slavery which should be decreed by them?

"But Mr. Greeley evidently thinks that this little change of names gets him over the whole difficulty. And he touches what he obviously regards as the point of the case when he adds that 'the Wilmot proviso' is 'to an established and admitted State' confessedly inapplicable.

"Without discussing the authority of Congress to insert a restriction against slavery in the act of admission, which was done with most of the Northwestern States, it is true that after a State has been established and admitted the Federal legislation has no power to apply to that State the 'Wilmot proviso'; and that by the uneonditional conversion of a territory into a State Congress divests itself of that power. But it is not easy for anybody-except Mr. Greeley -to see how the reference of the question, even when confessedly within its jurisdiction to a territorial legislature, as proposed by Gen. Cass, is more objectionable in a moral point of view than the voluntary divestment of that jurisdiction for the very purpose of shirking off the question upon the same legislature ealled by a different name. Gen. Cass's plan has some advantages over that adopted by Mr. Greeley.

"It is less evasive and more manly, frank, and honest.

"It may afford some chance that the fate of the various parts of this immense tract of unsettled lands shall be decided by the people who shall at some future period inhabit them after they shall be organized into distinct Territories, the more densely populated portions having been admitted as States; which might be somewhat better than leaving to a few thousand persons in Santa Fé and San Francisco to fix the destinies of hundreds of thousands of square miles in which not one of these persons ever trod.

"Above all, it would not, in the miserable attempt to 62 
aroid the question of slavery in the Territories by adnitting a State of boundless dimensions, incur the great and perilous mischiefs which we have pointed out in our two previous artieles, to the safety and permanency of the confederacy, and incur these evils without the least necessity or any compensating benefit.

"But Mr. Greeley says that "the North would be morally certain that slavery would not be tolerated' in the States to be formed. So said Gen. Cass in his Nicholson letter, when he proposed mnder a little different name to leave the question to be settled by exactly the same persons. So said Mr. Buchanan. So said Mr. Clayton. Yet nobody denounced their contrivances with more indignation than $\mathrm{Mr}$. Greeley. Talk of the Cass 'juggle,' the Buchanan ' compromise,' the Clayton 'trap'-the Greeley and Donglass juggle is worse than any of them."

The prostration of the Democratic party-whether by the defeat of General Cass or by the conditions which procured his nomination, it is inopportune here to discuss-though a great disappointment to Mr. Tilden, was, like most disappointments, good-fortune in disguise. It gave him the opportunity and provocation to derote all his energies and talents for the succeding quarter of a century to his profession, during which period of its service it rewarded him as the wisest of Israel's kings was rewarded for his obedience-with fance and fortmic. In less time than he had spent in making himself a leater of his party in New York, he placed limself in the front rank of the American har.

It was not until the year 1850 that $\mathrm{Mr}$. Tilden leased his first office for professional purposes after lis admission to the bar. It was on the third floor of what was then known as Jauncey Court, now replaced by majestic banking-houses, on the sonth side of Wall Street, a few doors west of William street. His landlord was Mlexander Hamilton, Jr., one of the sons of President Washington's first Minister of Finance. Here is a copy of their agreement, followed by a bill of Tilden's personal taxes for the previous year:

"This is to certify that I have hired and taken from 63 


\section{LETTERS AND MEMORIALS OF SAMUEL J. TILDEN}

Alexander Hamilton, Jr., the office, consisting of two rooms, on the 3 rd floor of the Jauncey Court Building, and marked on a plan of said building No. 1 (it being understood and agreed that if the above premises shall be rendered untenantable by fire, the rent shall cease during the interval occurring from the happening of said fire until the premises shall have been repaired), for the term of three years from the fir'st day of May, 1850, at the yearly rent of four hundred and twenty-five dollars, payable on the usual quarter days.

"And I hereby promise, in consideration thereof, to make punctual payment of the rent in mamner aforesaid, and quit and surrender the premises at the expiration of the said term, in as good state and condition as reasonable use and wear thereof will permit, damages by the elements excepted, and not to assign, let or underlet the whole or any part of the said premises, or occupy the same for any business deemed extrahazardous on account of fire, without the written consent of the landlord, under the penalty of forfeiture and damages. And I do hereby, for the consideration of aforesaid, waive the benefit of the exemption specified in the first scetion of the act entitled ' $A$ n act to extend the exemption of household furniture and working tools from distress for rent and sale under execution, passed April 11, 1842, and agree that the property thereby exempted shall be liable to distress for said rent; and also, that all property liable to distress for rent shall be so liable, whether on or off the said premises, wheresoever and whensoever the same may be found. 1850 ,

"Given under my hand and seal this

day of February,

in the presence of

"Shmuel J. Tilden." [Seal.]

This lease was renewed on the 12th of February, 1853, for three years, to end Nay 1,1856 , for $\$ 550$ a year, an increase of $\$ 125$ a year.

The rent paid for these two rooms by Mr. Tilden does not contrast more violently with the price of equal accommodations now, than his charges for his professional service during his first year contrasts with the rewards for similar 
work expected by his profession a half-century later, as appears by some of his bills, which follow, at that period:

The Daupind and Susquenanna Conl Company, 'To S. J. 'Timen, Dr. 1850.

Jan. 12th. To drawing bill to amend the charter of said company, and attending at rarious eonsultations and advising in reference thereto ...........\$150

Cinsosnut Hill Tron Ore Company,

To S. J. 'Tilden, Dr. 1850.

Oet. 18-24. Going to Taneaster, Pa., to attend sheriff's sale and attending negotiations in Philadelphia $(61 / 2) \ldots \ldots \ldots \$ 50$

Dec. 12. Drawing articles of association for the company .............. 100

“ 15. Drawing conveyanee from Mr. Sander to Mr. Pyne............ 10

Drawing trust deed from Mr. Pyne to the trustees of the company..... 25

Jan. 8. Examining and preparing......... 50

Aug. 1. Drawing conveyance for P. R. Pine to the corporation ............ 10

Release and conveyance of the trustees. 10

$\$ 555$

The Pequa Rail Road \& Improvennento., 'To S. J. Thlone, Dr. 1851.

Jan. 1. Drawing articles of acreement for a mion of the lmsiness of the Dauplin \& Sus. Coal Co. and sundry consultations in respeet thereto-proportion of Pequa Co.\$125 Drawing bill for a mion of the two companies and consultations in respect thereto-proportion of Pequa Co........ 50 


\section{LETTERS AND MEMORIALS OF SAMUEL J. TILDEN}

The Dauphin \& Susquemanna Cont Co.,

1851.

To S. J. Tilden, Dr.

Jan. 1. Drawing articles of agreement for a union of the business of this company with that of the Pequa Co. and sumdry consultations in reference thereto-proportion of the D. \& S. C. Co.............\$125

Drawing bill for a union of the two companies and consultations in reference thereto-proportion of the D. \& S. Co. .

The Pennsulvania Conl Co., 1851.

June 17. To preparing another draft of the assignment of contract to obviate objections made to execnting same....... \$15

“ 28. To preparing another draft of an assign-

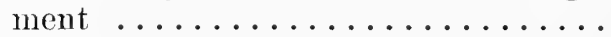

To preparing another draft of a new contract $(36$ folio $) \ldots \ldots \ldots \ldots \ldots$.

Apr. 7. To going to Albany in respect to water

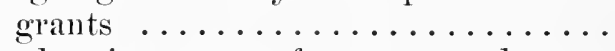

Mar. 19. To drawing power of attorney and agreement for the masters of the Wyoming Coal Association to accept stock of the Penn. C. C................. 20

“ 17. To consultation in reference to...... 10

“ 18. Certain Coal contracts........... 10

To advising in respect to the mode of transferring the property of the W. C. A. to the Penn. Coal Co., and attending numerous consultations in respect thereto, as well as the meeting of the stockholders ..............

To examining and revising conveyance of the Wyoming Coal Association to the Penn. C. C............... 


\section{LETTERS AND MEMORIALS OF SAMUEL J. TILDEN}

$15 \div 1$

Jume 20. To advising in respect to power to contract the satue.............\$100

" 27. To going to Philadelphia and conferring with Judge Malloy in respect to your

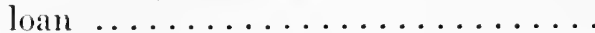

July 1. 'To drawing resolutions and proceedings to be adopted by the board authorizing the loan of $\$ 600,000 \ldots \ldots \ldots$. To drawing the trust mortgage to secure its repayments-tlie form of the bond and other necossary papers, and advising in respect to the various proceedings mil the transaction was consum-

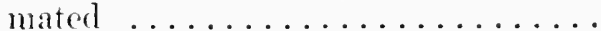

Sept. 3. To attending and advising in respect to rights of company in purchase of water right at Williamsburg....... 10

“ 5. Ditto .................. 10

General counsel fee.......... 250

$\$ 1780$

"Office of Receiver of Taxes, New City Hali, Park. "New YorK, Dec., 18.9.

"To the Supervisor's of the City and County of New York, for Taxes, 1849.

"Mr. Simil. J. Tildex.

"To tax on personal estate, 11 Fifth Avenue.

"Valuation, 2000 .

" Rate, 118.32 .

"Tax, 28.66."

Mr. Tilden had already become interested in a small mar in the establishment of the first balance dock ever provided for the New York harbor. IIis friends, O'Sullivan, Waterbury, and Secor, were also anong the number interested with him. The following eontract shows the nature and extent of Mr. O'Sullivan's interest. The venture did not prove very profitable to them, nor to have received much attention froin Mr. Tilden. 


\section{LETTERS AND MEMORIALS OF SAMUEL J. TILDEN}

DEPOSIT WITH MIR. TLLDEN TO SECULE A LOAN TO MR. O'SULLIVAN

"New York, Nov. 22, 1850.

"Whereas, I have this day drawn a draft at three months on C. A. Secor in faror of Messrs. Wright \& Betts for about sixteen hundred and fifty dollars, and the same has been accepted by said C. A. Secor, I hereby authorize and request you to hold twenty shares given stock in the Balance Dock Company (out of the forty-two shares of which the certificate is in sour hands, with my porver of attorney to make transfers of the same dated Nareh 14, 1850), as security for the parment of said draft; said twenty shares to be sold for payment of same unless satisfactory provision for its payment be made by me within one week prior to its maturity. "To S. J. Tilden, by

\section{"J. L. O'Sullivax."}

"I hold a certificate of twenty shares of stock in the Balance Dock, with a power of attorney from J. L. O'Sullivan in regard to the same, which have been deposited with me by Messrs. O'S. and Secor, and I accept the trust so far as the said papers may enable me to carry it out.

$$
\text { "S. J. Tilden." }
$$

"New York, Nov. 22, 1850."

TILDEN TO MRS. CIIASE*

"NEw York, Nov. 29th, 1850.

"MY DE.ar MLAdan,-Your letter of Oet. 13th, and that of Mr. Chase aceompanying it, came at the commencement of an illness which disabled me for some time from making the inquiries which yours requested. Since my recovery I have been diligently seeking to learn something of the line of steamers destined to tonch periodically at Vera Cruz and Tampico. Mr. Geo. Law, who is the principal man in the Chagres line, and Mr. Wetmore, an associate of his in that enterprise, inform me that nothing of the kind has been connected with their line; and they agree in thinking that, although such a proposition was before Con-

* This letter was addressed to Mrs. Franklin Chase, whose husband was U. S. Consul at Tampico. 
gress, it did not pass. Mr. Brooks, who represents this distriet in the IIonse of Rep., and who is conversant with such matters, is of the same opinion. Mr. Croswell, of Albany, not of this eity, who is interested in the Chagres line, and whom I was fortmuate enough to meet a few evenings since, has the same impression, lont referred me to young Mr. Worth, of this city, as having something to do with a project for such a line. On inquiry of that gentleman I find that he is not aware of any action of Congress on the subject; that the project is purely commereial, and that it is so very immature that it can seareely be deemed to have an existence. This was for a line between this city and Vera Cruz. The laws of the last session have not as yet been published, so that I could not examine them. I am thus particular, because one gentleman of whom I inquired had an impression that such a bill did pass. While there seemed to be very little definite knowledge, my conelusion is that no sneh line has been anthorized, but I shall keep an eye to the matter, and conmmnicate to you any information which may seem inportant.

"I formd in a N. O. paper that the steamer Alabama will make trips at intervals of about 20 days from that place to Vera Cruz. The news that reached you may have originated partly in this eiremstance and partly in the pendency of a proposition, such as you mention, in Cong.

"It would give me great pleasure to aid Mr. Chase, in the way you desire, so far as I may have power, if such a line should be established; though the thing is as yet so indefinite-and I am inclined to think will remain sothat I cannot estimate my ability to serve him.

"The friends of whom you inquire-Mr. Green, Miss Green, and Miss H.--are well and pursuing happiness ardently in their enstomary modes: each one pursning his favorite phantom, the poet hath it, but I will not apply to them the association that rises in my menory. There are objects in life which are not phantoms-tho' little pursued, and not by many. I am tempted to seek for myself the gracions welcone that awaits the bearer of good-tidings by telling you that Miss. II. intends to leave here on a Southern tour in the latter part of Dee., and has some thoughits, even hopes, of persnaling her father to prolong the exeursion to Tampico. But do not flatter yourself too much. Wind and weather are not less uncertain on the Gulf than 


\section{LETTERS AND MEMORIALS OF SAMUEL J. TILDEN}

elsewhere, and even the steady purpose and persuasive

- power that characterize our friend may not prevail agaiust every mischance.

"The change in the nat. adn. was as sudden and remarkable as you regard it. The poliey of the gov. was a little modified by it, but on the whole it was most striking as illustrating how quietly our political machine works, even while the hands that seem - and seem only - to guide it are shifted. I do not share, to any considerable extent, the apprehensions entertained or professed by many as to a dissolution of our federative union. I would not needlessly put its bonds to the test. But I think they would prove stronger than is generally supposed; that danger would bring upon the theatre of publie affairs a higher class of men than the holiday patriots who figure there in a season of peace-men who would represent the actual sentiments of the masses of our citizens, the serious, earnest purposes, now applied to prirate objects, that would be turned to the preservation of the Union as an important, practical means to great public ends. The idea of Ameriean nationality - progress and destiny - is the masterthought in the minds of our people, and creates a tendeney to unity in the gort. quite strong enough. I have, too, a feeling-for it may be that, rather than a conclusion of reason-on this subject, which some may call superstitious. I believe that the gradual amelioration and eulture of our race is in the inevitable order of Providence. I see elements which have been and are preparing our country to aet a grander part than any has hitherto done in this great plan. That part is to be wrought out, not by an indolent repose on what our ancestors have ordained for us, but by trials and saerifices and earnest efforts to solve the great social and civil questions which necessarily arise in the experiences of a nation. It seems to me-but here I nay read the sacred oracles not aright - that the Union is an essential condition to the destiny we appear appointed to fulfil; and I believe it firm enough and strong enough to endure the conflict of social and political forces which is going on within its bosom. It will survice them all, working out what it can, and as far as it can, and easting off to a future period what it cannot now entirely work out.

"I resume my letter which has been in my portfolio unfinished for more than a week. A current of affairs sud- 


\section{LETTERS AND MEMORIALS OF SAMUEL, J. TILDEN}

denly struck me, and swept me on so incessantly that I have not before been able to return to it. You must not infer, however, that I affect any speeial inclustry, or that I an ordinarily so busy. My life has vibrated between a leisure in which I ammsed myself with books, and the greatest activity in pubic and private aftairs; and, if the last few months have been as engrossingly oceupied as any part of it with professional and personal business, I do not expeet or desire it to be generally so hereafter. What has most exacted attention was temporary and oceasional, and has, as yet, produced, and may produce nothing to me or to others, though lest such a confession excite too mucli pity for me I will add that in the mean time what has eost ne comparatively little trouble has been sufficiently fruitful. $\mathrm{My}$ disposition is not to permit merely privale business to engross me, nor to be in any of an inprofessional nature which ercates anxiety. I have never been accustomed to surrender to it my inner life, or to allow its cares to fill those little interstices between actual oceupation which are instinctively given to, and which eharacterize our ruling habits of thought and feeling. There no doubt is danger, as the relations of business multiply around us and our enthusiasm for public objects is qualified or weakened and our sympathies often come back upon us as the chilled blood returns from the extremities to the heart, that what furnishes ocempation to our activity withont the trouble of seeking it and without making us inquire whether we choose it, will grow too much upon our attention. But I desire to reserve something to better purpose-something to friends and to myself, and possibly, if hereafter I can recall the enthusiasm of early years, with a share of its former strength and steadiness, something to consecrate life by a sense that it has not been wholly given to objeets so selfishly egotistical as are most of those which we pursue. It is time for me to stop; for I am moralizing, when I began merely to exclude a possible inference that $T$ have not leisure to care for the wishes and interests of my friends, and to assure you that I am always happier if $\dot{I}$ ean serve them, and glad to talk with them, as I now do, even if it be at such a frightful distance as, in this age of ocean steamers, railways, and telegraphs, to put a quarter of a year between question and answer.

"I wrote you a very $\frac{\operatorname{long}}{71}$ letter-I tremble to think I 


\section{LETTERS' AND MENORLALS OF SAMUEL J. TILDEN}

ever addressed such a missive to a lady-all full of finanees and fiemres, on about the first of Oetober. I mention it lest it may have miscarried. I should regret if you have failed to get the answer it attempted to your inquiries. I have hoped, and do hope, to hear from yon in respect to it and its subject, if I can at all aid you. As a whole, it was not intended to be answered - as somebody said of his own speech-but I do look for a reply; I hope it may be an early and farorable reply-to some parts of it-as, for instance, that you are rapidly maturing your plan of changing your residence to this country, and that, at all events, you are coming over here next spring. If you should say that, you may take your own time for the statisties of the moneymarket and of money-making. Waiting patiently as I can for such an answer, and begging you to present my best respects to Mr. Chase, I remain,

$$
\begin{aligned}
& \text { "Very truly, your friend, } \\
& \text { "S. J. Tilnden." }
\end{aligned}
$$

COPY OF DRAFT-LETTER, FULL OF " FINANCE AND FIGURES," REFERLED TO IN THE PRECEDING LETTER

"There are, of course, the U. S. sixes, if you are content with so low a rate of interest. The New York stocks are about the same. There are others which are lower. If put to the ehoice myself, I should prefer bonds seenred by mortgages on real estate, or, as we familiarly call them, b. and m. at 7 p. c., which, with eare, can be had, even in the present plethora of money. There are also many varieties of bonds of private companies paying 6 or 7 p. c.; but, as a general rule, I shonld decidedly prefer bonds and mortgages on real estate.

"There are also stocks of private companies. Many of the banks are earning 7, 8, 10, or even more per cent. But these stocks are at considerable premimms, and have risen much recently. They camnot be always continuing on the ascending series. When a commercial depression shall occur these bonds will feel it more promptly and more deeply than that of most corporations; their dividends will be redueed, the premiums (which are equivalents for future, unearned, dividends) will fall off; and you may lose more by this decline than you have realized in the excess of the dividends over a fair interest. The same remark is appli- 


\section{LETTERS AND MEMORIAIS OF SAMUEL J. TILDEN}

cable to the few railways which pay rery large dividends, althongh they are not so sensitive to the fluctnations of comneree as the banks-in this as in the other case. The Delaware \& IIndson Canal Company-whose business is to produce and bring to market anthracite coal - has declared abont $16 \mathrm{per}$ cent. for the last four or five years. The premium on its stock is now $50 \mathrm{p}$. e. That is lower than it has been, because of special ciremustances, while I think that the next year's business will be better. The dividend is over 10 p. e. on premium and all. I would rather risk the continuance of its high premimm than in any other case of a railroad. I may say, any other similar case. There is a similar company which has just come into operationa very solid concern-which we think will be at least as good; its stock at a premium of 15 p. e. It is not so well known or so promptly marketable, and its stock is in a rather complex form, which it is expected to simplify next winter. It would be idle to say that I have not great confidence in it, since I have transferred what I had in the other to it, and have put in it more than the sum you mention in your letter' but $T$ should not like to have another person invest in it or any similar thing merely on my judgment; and, to do so on his own, he ought to have more detailed knowledge than could be communicated in this hasty letter. The claim is that its stock will not advance much for the next 3 months-perhaps not for the next 6 or 8 months.

"There are also classes of ins., to some of which I have great objection, but it would be futile now to discuss their merit.

"With respect to investments in private companies generally, I have some obscrvations to make. A very large proportion of one's means should not be concentrated in one institution, especially withont the most thorough familiarity with its affairs. A wise selection between them requires at any time special knowledge and individual judgment; and more so now than usually. The abmolance of capital and low rates of interest causes high premiums to be given for the most productive storks as well as the most so that it is scarcely possible to get them at prices [half a page is here utterly undecipherable] unless in special eases where the enterprise is comparatively new and unknown, or its real merits are not fully appreciated 


\section{LETTERS AND MEMORIALS OF SAMUEL J. TILDEN}

by the public, in which cases you rely upon what you suppose to be superior information or judgment.

"I ought to add, in qualification of those general views, that I do not mean that the market has reached its highest. elevation. I think it probably has not; nor can I now see the particular time when, or the particular event by which a change is to take place. We are not in a state of high speculative excitement; we appear to be tending to such a state, though causes may occur to check the tendency. But we do know that-whether the present abundance of capital and prosperity of business shall, temporarily, increase or not-we camnot expect them to continue for a very long period, even to the present degree. It is desirable to make your investment at as low prices as possible, in order to enhance your interest and have greater security against possible contingencies; but even this consideration may be so modified by peculiar ciremstances that it is difficult to state an absolute rule applicable to all cases.

"On the whole, your main interest is to find your money safe and arailable when you come here, and are able to make a permanent disposition of it on your own judgment. I am gratified to be able to believe that you have already secured an ample provision for the future-its reasonable tastes as well as its necessities-at a rate of productiveness which will give the greatest safety. Anything that you can hereafter add to your income or capital would be really of very slight importance to you, compared with what you now have. I do not undervalue your fortitude and energy, or concede to own to the impertinent advances of time, when I say that your chief care should be to avoid even the possibility of being compelled to begin anew the work of life - so far as the providing for its material wants can be called such-when, if the period most fitted for that purpose have not passed, the years which have been allotted to it cannot be recalled. The advantages of such skilful disposition of your means as are consistent with safety - and such adrantages there are-will be to be enjoyed by you when you shall become - as I hope you soon may-a resident in our country. In the mean time, a deposit with the trust company seems to be as good a temporary arrangement as you ean make at your distance from the scene or as I ean suggest in my ignorance of your particular affairs, wishes, and future movements. I need not add that any aid which I 
can give you in making this or any other disposition of your remittances which you may prefer will be very cordially rendered. I shall be happy also to answer further inquiries and convey additional information, as far as can be done by correspondence; and shall hope to do so more promptly than I have been able this time, and more briefly; for without purpose to be very I happen to have been visited by unusual concourse of people talking to me about all sorts of things and by a necessity of my talk with you very rambling and diffuse. I have had the to read it over-with something of dismay that I should ever have written such a letter to a lady, and I must beg that it be communieated to Mr. Chase, to whom, in truth, it seems mainly to he addressed -and to all eyes but his remain forever a sealed book. It might ruin all my prospects with less forbearing fair ones if it were supposed there could be any risk of a similar epistle.

"If you should place a deposit, or otherwise temporarily dispose of such remittances as you may make through the winter, would not the true policy be for Mr. and Mrs. C. to come on here for a short time, next spring or summer, to make more permanent arrangements? The journey is not much, and might be more than repaid by the business results. If you could leave your affairs at home the trip might be useful in all respects. I have left myself little space for other topies. But I must find room to say, in reply to the friendly message of $\mathrm{Mr}$. Chase, that I consider myself already, in some sort, acquainted with him, and to beg that he will not measure the little attentions I had the pleasure of rendering to a lady who interested me, as well by her personal qualities as by the situation in which I met her, by the disproportionate sense of then which she entertains.

"I fear the probability of my being able to visit Tampieo at present is not sufficiently substantial to fabricate a dream of. My consolation must be the hope of neeting you here, in which I trust you will not disappoint me. The anthority with which you commission me to "say many kind things", to eertain of your friends-if intended to be general-is too flattering in its conferment and ton agrealle in its exercise to be renounced. And yet I fear I should not be the 'faithful agent' you liope if I did not candidly admit how 
little, in this respect, you need, or can be aided, by any service of mine.

"Hoping to hear from sou shortly, and to see you at an early period, and wishing Mr. C. and you every prosperity and happiness, I remain,

$$
\text { "Very truly, your friend, ", }
$$

$1851-1860$

\section{VAN LUREN TO TILDEN}

"Lindenwald, Jany. 5, '51.

"Mr DEAR SIR,-Please let me hear from you at your earliest convenience on the subject of my money as it lies unimproved; also your opinion of the best investments now to be made. What would you think of putting five thousand dollars in Erie income bonds if you do not take it? Explain to me the character of the stock and the principles upon: which it has been issued. Don't forget Lawrence. Excuse me for troubling you, and believe me,

$$
\begin{aligned}
& \text { "Very truly, } \\
& \text { "Yours, } \\
& \text { "M. Van Buren." }
\end{aligned}
$$

The measure for the enlargement of the Erie Canal at an expense of nine millions of dollars, projected by jobbers in what are still known as the canal comties, and which is referred to in the following note of Mr. Burwell, was so effectually resisted by $\mathrm{Mr}$. Tilden, both by speech and pen, that it was put to sleep for more than forty years, when it reappeared and was passed. It resulted even more disastrously than Mr. Tilden had predicted, and to this day no one knows what became of the $\$ 9,000,000$ that were spent, though no one will pretend that a new canal-boat was built or another ton of freight was ever carried through the canal in consequence of that expenditure.

\section{BURWEI.L TO TILDEN}

“ Albany, March 30th, 1851.

" Mr dear Sir,-I presume rou have observed the canal bill, which increases the State debt $\$ 9,000,000$. Will you 
not devote some time to-morrow to get letters from the money kings-Messis. Beeknuan and Morgan and Willians -to have the bill defeated?

"An effort is to be made to press the bill through this week, and it is very important there should be some delar.

"I write you because I know you will feel an interest in defending those constitutional provisions you contributed so essentially to form. I lave heard that many of the sound financial men of Wall Street are opposed to this new scheme of debt, and particularly $\mathrm{Mr}$. C. W. Lawrence, of the Bank of the State of New York. I hope you will devote one day more to defend the public faith.

"I should not write, but I really feel it a solemn duty to urge every one I can think of to the defence of the Constitution.

"If you could get up a short remonstrance you would do something worthy of your past labors; but have it sent up by Tuesday or Wednesday.

\section{"Yours truly, "D. Burwell."}

By the death of President Taylor, in 1850, the VicePresident, Millard Fillnore, of New York, became Acting President.

Whether, and if any, to what extent, the free State and the slave State partisans in New York, on whose political course the next Presidential election was largely dependent, would be able to act together at the ensuing Presidential election, had become an absorbing question throughout the nation in 1851. Gideon Welles had for many years been prominent among political journalists as editor of the ILartford Times. IIe had also been a devoted champion of the principles and policies of Presidents Jackson and Van Buren, and was at this time a warm partisan of the Freesoil wing of the Democratic party. Me later had the honor to be selected by President Lincoln in 1861 for his Secretary of the Navy, the department of the military service which during the Civil War of $1861-5$ proved most uniformly victorious and efficient. 
GIDEON WELLES TO TILDEN

"Confidential.

“Haktrond, 2/th Sept., 1851.

"Dear Srr,-I am wanting light on matters political, and write you for guidance and information. It was my expectation to have gone to New York about this time, but as I cannot, excuse my writing. My general views and my peculiar position (peculiar for me) I very frankly gave you, and also the attitude of things here when $I$ saw you in June.

"Your convention is to me somewhat of a mystery, for I have seen no one from your State to enlighten me, and there is no one in the region hereabout better informed than myself. Things have not taken, in all respects, the course I could have wished and, indeed, expected, but it is not uncommon that we are controlled by circumstances rather than circumstances by us.

" $\mathrm{My}$ object is to learn from you the course that the Democrats of your State will be likely to take in regard to the Presidential election. I need not say to you that whatever you may communicate shall be in strictest confidence, and shall be submitted to no other eye or ear than mine; but it may be of material benefit for you and for us in Connecticut if I can have some indication of the course which our friends in New York intend to pursue.

"As I remarked to you when I last saw you, I found things in our State in a very unfortunate condition when $I$ returned from Washington, and while I would not commit myself to the schemes on foot, I at the same time did not think it expedient or useful to place myself in exactly an antagonal position to old associates and friends. I have therefore stood somewhat aloof-commenting on and criticising measures and men, to the great annoyance and disappointment of some, who thought it in their power to compel me to take a position as they had done by Niles.

"At this time the party in this State which supported Cass do not mention him. He seems to be dropped by universal consent. His leading friends, the managers of what you call the Hunker party, are generally inclined to Buchanan, but the more efficient and active portion of those who went with him are disinclined to take Buchanan, and, to a considerable extent, avow themselves for Houston. I 
have been in exactly that position when I did not feel inelined to allity their differences.

"In the nican time, within a few weeks past and since the death of Woodbury, some of the shrewd and cunning frienels of Buchanan are talking up Donglas. Withont gor ing into speculations on this matter generally, I can well pereeive the local design and hearing which those novements may have, and hence my desire to know something of the intentions and nltimate object of the real Demoerats of your State, for it is desirable that we should harmonize.

"If I conld make the next President, Col. Benton would be the man, althomgh the old man takes oceasionally strange freaks. In a late St. Louis Union I read a strong article in favor of Buchanan, backed by an elitorial equally strong which surprised me. T am no partisan of Buchanan, whose course on all recent questions appears to me extremely objectionable, and, in fact, lis career is not one that I admire generally. Cold, selfish, intriguing, and heartless, he panders to vicions doctrines; he is not a root-and-branch Demoerat, and I always doubt his sineerity. I should very much prefer Marey, especially if he conld disentangle himself from a few bad associates. From some of the proceedings of your State convention, and a few odds and ends in the papers, I have been half inelined to think that some of Marer's warm friends threw their influence with the Barnburners, and defeated the extreme ilnnkers. This is mere speculation of mine, without a word from any one, and made perhaps in the absence of any more obvious eause for what then oremired.

"In former years I was acenstomed to get from Mr. Wright a letter or two ammually that made my pathway clear, and his suggestions enabled ne sonetimes to do the canse eflicient service. At this time $\mathrm{I}$ feel the necessity of knowing something of the probable direction on friends in New York will take, and I must rely on you for hints, suggestions, and views. There is quite a disposition to talk up the Presidential question, and our active busybodies seem anxious to eonnect thenselves in season; and without appearing intrusive or actually doing a great deal, I am perhaps in just such a position as enables me perhaps to do more active and substantial service than a much abler man, differently situated. I therefore write to you as an old acquaintance, knowing that you cau give me light. 


\section{LETTERS AND MEMORIALS OF SAMUEL J. TILDEN}

"Where is our friend Genl. Dix, one of your best elearheaded and pure-minded men? I suppose things are in such a condition that he could not be brought forward, but how infinitely superior to most of the men named for Chief Magistrate. Let me hear from you as early as you conveniently can, and believe me,

$$
\begin{aligned}
& \text { "Very truly yours, } \\
& \text { "Gideor WELLEs. }
\end{aligned}
$$

"P. S.-Your father, as well as Gov. Wright, was an old correspondent of mine, and hence, in part, my claim upon you.

$$
\text { "S. J. Tilden, Esq." }
$$

William L. Marcy had been Governor of New York from 1833 to 1839 , and in 1852 , as will be seen by the following letter, he was already indulging dreams of succeeding Mr. Fillmore at the impending Presidential election, which, however, resulted in the choice of Franklin Pierce. Mr. Marcy had too many friends like Van Buren and Tilden and Dix and Flagg to be trusted at the head of the government by the partisans of slavery, while and because of those friends he was wanted in the Cabinet for his influence with those statesmen in New York; but they took care to put him in the department where he would have least occasion or opportunity to interfere with the policy of the slave-holding class. He was made Secretary of State.

\section{W. L. MARCY TO TILDEN}

"Private.

"Albayy, Apl. 2d, '52.

"MY DEAR Sir, - Though I have heard of nothing calculated to excite alarm, yet I do not feel quite easy as to what may be the result of the delegate meeting on the 7 th inst. As Lt.-Gov. Church does not stand entirely unexposed to attacks on account of the canal lettings, I think it would be quite agreeable to him to be selected as one of the State delegates. Should his selection be pressed it may embarrass the proceedings. I have information from Washington that Dickinson's man, Birdsall, is here exhibiting much bitterness towards me, and has distinctly broke ground for Dickinson as a candidate. As he cannot carry the State it will 
be important for his object, as it would he to Gen. C.'s friends, to ereate an impression that no one can carry it. He will therefore endeavor to get up a scene of confusion here at the delegate meeting. Though I have no intimation on the subject, yet I do not donbt that he will propose a wholesale endorsement of the compromise. If so, the blow must be skilfully parried.

"I also fear" the Hunker delegates favorable to me will stiffy insist on Hunker State delegates, but will go far to gratify the other section of my friends as to the particular persons.

"I allude to these things to enforce the request I make to have rou be here a day or two before the delegates meet if you eonveniently ean.

"If we ean surmount the embarrassments which may arise in this matter, I flatter myself that our futnre course will be more smooth.

"I am inspired with confidence from the information I get from Washington that things, as they appear there, are not worsening for me, and if the business at the delegate meeting is done as it ought to be my prospects will be much improved.

$$
\begin{aligned}
& \text { "Yours truly, } \\
& \text { "W. L. Mancy. }
\end{aligned}
$$

"Saml. J. Tilden, Esq."

\section{MARTIN VAN BUREN TO S. J. TILDEN}

"Linderwald, Sept. 1\%th, "j2.

"MY dEar Sur,-Aceept my thanks for your attention to my stock affail. Please deposit the balance to my eredit in Mir. Worth's hank. I regret your inability to visit me, as I long to have an old-fashioned chat with you.

$$
\begin{aligned}
& \text { "In haste, } \\
& \text { "Very truly yours, } \\
& \text { "M. Vix Buren." }
\end{aligned}
$$

TILIEN TO

SCGGESTION FOR PRESIDENT PIERCE IN TIIE ORGANIZATION ANI CONDUCT OF IIS AMIIINTRATION

"Nkw York, Jany, 1,jth, 18.j.3.

"MY DE.AR Sir,-T thank you for the copy of Hawthorne's Memoirs. It woull have reminded me, if I had 
forgotten, that I promised to write you my views on the subject of our eonversation when I last had the pleasure to see your. I should have done so earlier, but engagements, which it is no exaggeration to call incessant, have left me no opportunity.

"The preliminary question is, on what general theory is the new administration to be formed? Is the Cabinet to be composed of those who are commonly regarded as Presidential men-who were candidates for the recent nomination-and are surrounded by the affiliations which naturally grow up around those occupying that position? It seems to me that this would be attempting to stand steadily and firmly on a half-dozen different stools. The President might himself look after the suceess of his administration, while his constitutional helpers were thinking how each measure and each appointment would affect their pretensions to the suceession; or he might content himself with the formal honor of presiding over the eouncils of these heads of factions. But, in my judgment, he ought to be-not what Vietoria is in the British government, not a grand Elector, as Sieyès would have made Napoleon, not a mere chooser of the actual rulers-but the real and responsible head of the administration. That he may be such, he should have, as far as practicable, a Cabinet able to perform its duty towards lim, faithfully and effectively, and not inviting by the aspirations of its members internal dissension or external hostility. In the last term of an administration, it may be diffieult to exclude pretensions to the suceession. But why incur the embarrassments which they never fail to generate, during a first term, unless it be certain that it is also the last! And is it to be now assumed that the Democracy will look from the candidate through whom it solved the difficulties of a choice at the last convention, and to eandidates through whom it found itself unable to solve those difficulties? It is not clear that the party can, after so reeent a disorganization - if it could under other cireumstances-be sufficiently consolidated in a single term to be instrumental to any great public service. But it is elear what will become of the family discipline and how the farm will be managed if the old gentleman begins by announeing his own decease and inviting the boys to seramble for the inheritance. Polk tried that, secretly meaning all the while to be his own heir; and while he contrived and 
they serambled, the inheritanee went to strangers. Let not Gen. Pieree content himself with being a loose and tenporary bond of mion between factions; but rather let him aim to fuse those factions, and constitute a single, compact party.

"Now what is to be done with New York? Some will say avoid all difficulties by taking no member of the Cabinet from that State. That would be better than to (lo worse; and, if on dne reflection it should be deemed most expedient, I should not personally complain. But it is not a policy after my heart or my judgment; nor does it tend to constitute a party ont of the fused elements of factions. An evasion policy, in such a case, is a feeble policy.

"Well, who then shall be taken? The public regard Messrs. O'Conor, Dickinson, Marey, and Dix as candidates; and therefore I may be justified in remarking upon them as such. The first two $\mathrm{I}$ shall not say mmeh about, because I do not suppose their present relations to the prevailing policies of the State will make them regarded as adnissible selections.

"Mr. O'Conor is a man of extensive and accurate legal learning, of an acuteness of reason somewhat excessive even for the higher uses of his profession-of great mental activity, indefatigable, vehement and sarcastic in controversy; remarked at the bar as able rather than wise, and renarkable for a want of tact. What these qualities-not weakened by a life almost exchusively forensic-would naturally make him in polities, where they are not eomteracted by the large knowledge, long experienee, and settled rules and habits that modify their effects in his profession, and where the opposite qualities, the power, not of dissenting or contesting, but of moulding, construeting, and organizing, of determining one's self and representing others, are mainly required, may be imagined. Add inexperience in polities, rery limited aequaintance with its subjects, its questions, its history, its methods or its men-misettled convietions, a tendeney to capricionsness, and as little as can easily be found of that capacity which cnables a man instinctively to act with others or make them act with him, and you have the political aspects of his eharacter. Whether in personal judgment or action in polities, in administrative comneil, in a deliberative assembly, or in leading or aiding to lead a party of a nation or a ward, his destiny is to illustrate 8.3 
how little fitted to such purposes may be talents conceded to be eminent in a peeuliar sphere. 'This opinion is the result of many year's' observation. It was confirmed when I was associated with him in the conrention that formed the present Constitution of this State, and, in an intercourse constant and never unfriendly, was a daily witness of the development of his characteristics. The partiality of his friends would not change the nature, though it might lessen the degree, of this eriticism. No one has suggested him except as Attorney Genl.; and for that station, I presume, on the idea that its duties are purely professional. If that office did not share in the general administrative councils of the President; if, as a legal adviser, he were not required to look at the mixed questions that come up before him somewhat with the eye of a statesman as well as that of a mere lawyer-or at least with the largeness and comprehensiveness of a judicial view; if he had no duty or utility beyond conducting the cases in the courts in which he occasionally appears for the United States, certainly there could be no objection to the personal adaptation of this gentleman, and, if that member of the Cabinet from New York need have no relation to the majority of the party there, which has the entire State government, and whose ascendency is every day becoming more complete and solid, and but a very ineffective relation to the minority, if he need represent nobody and be capable of representing nobody, such a selection might not be injudicious as respects the Democracy of the largest State in the Union.

"I ought perhaps to add a matter of information without going into discussion of political antecedents that in our great financial controversy from $1836-7$ this gentleman was with the Thigs, and was not again visible in our ranks until 1844.

"Inferior to either of the other gentlemen mentioned in general abilities and acquirements, and to either of them, except Mr. O'Conor, as a politician - and not strong with his State in any of his political antecedents- Mr. Dickinson has brought himself into his present unfortunate relations with a great majority of the party here by the extreme positions he has oceupied on questions which have divided the State, and still more by the fatuity with which he has followed Judge Beardsley and Mr. Croswell in a poliey which must have been fatal to the party if it had not sooner been 84 
fatal to its adrocate. I mean the policy of resisting every attempt at an honorable or practicable union of the Demoeracy of the State-on the chance that, while the prominent men of the section, which formed a majority of the whole and had many sympathizers from the rank and file of that section, conld be made through the influence of association with the party in other States; and that, while the Democracy of the Union should take the risks of the experiment, those who got it up would, at least, own the wreck. Fairer and wiser men saw that such an experiment in a party which rarely commands a majority exceeding two or three per cent. of the aggregate vote, even if more successful than could be reasonably hoped for, could have no result but to leave New York as thoroughly federalized as Massachusetts or Vermont for a generation to come. But the folly of the selieme was no less in its personal aspects. It mistook the sentiments as it underrated the sense of the masses of the party. They, as everybody ought to have seen, were in faror of a reunion on equal and honorable terms. And the attempt to resist it - which, if openly made, would have been generally rejected-was sufficiently pereeived to break the hold of its anthors upon the masses of their own section, who, althongh sometimes in a collateral question where old associations or prejudices could be appealed to showing a large minority have been drifting from these gentlenen ever since, and many of them resuming relations with the radicals with whom they formerly acted.

"Gov. Marey and Genl. Dix both possess the important requisite of being of the union Democracy of the State, and are both capable of fulfilling the duties of a Cabinet station with signal ability and distinction. I express my judgment between these gentlemen, not without regret arising from kindly personal disposition towards the one against whom that judgment, mnder all the circumstances, must be. But I sliall state it frankly, and briefly some of the reasons on which it is founded.

"It seems to me, in the first place, that the selection of Genl. Dix is most wise and right in respect to the mutual relations of those who, acting generally with both these gentlemen, sinee the remion of the party in 1849, would be divided in preference between them. On the first nomination of Gor. Seymomr, in selecting a State candidate for the recent Presidential nomination-in choosing the two 
State delegates to the national cenvention on the renomination of Gor. Seymour-indeed, on most of the important occasions since the reunion, the radicals, while constituting far the larger and more effective element of that union, have conceded almost everything. The magnanimity with which they have done so, and the fidelity with which they have carried out the measures in which it has been done, have been strongly recognized by Gov. Marcy and his friends. These concessions have sometimes been not without dissatisfaction at the extent and frequent repetition of them; nor without large demand on the credit and patience of those who have been the means of inducing acquiescence in arrangements, in which, while one side contributed most of the capital of the partnership, the other received nearly its entire benefits. I feel some right to speak on this point without suspicion that I am swerved by personal associations from a fair judgment as respects all parties, as well from the general position I have held on these occasions as from the part I took in some of them.

"It may not be improper to mention an instance. When the two State delegates to the national convention were to be chosen, Gov. Marcy, as desiring to be presented as the State candidate for the Presidency', and Gov. Seymour as a candidate before his own party the first time after his defeat before the people, felt their fortunes rery deeply involved in the result. Gov. Marcy wrote to me requesting me to attend the meeting of the district delegates at Albany, and I did so. I never knew either of those gentlemen manifest more anxiety or having to confront more serious embarrassments. It had been the settled understanding that one Hunker and one radical should be taken for the State delegates. Most of the votes relied on to make the choice were radicals; and prominent men of that section, some of whom the radicals most desired to send, strongly wished to go. It seemed to Gov. Marcy necessary to take two Hunkers, but he felt the embarrassment of asking it, especially on the grounds that could alone be rendered; and others, who had to make the choice or were in firmer association with those who had to make it, were not easily convinced of the nccessity or propriety of such a course. The difficulty was at length solved by our passing our favorite men and assenting to elect Mr. Seymour and another Hunker. Those of us who have, on this and other occasions, felt the 
strain with our own friends of kecping the elements of the union Denocracy working harmonionsly and efliciently under such eiremustances, have a right to be heard when we express the conviction that the present is a fit time for Gov. Marey and his friends to evince some mutuality in their relations towarls the radicals; and that a more safe, proper, and moljectionable opportunity to reciprocate the magnanimity with which they have been treated cannot be offered than in assenting to the selection of Genl. Dix for the Cabinet. Such I believe to be the general sense of those who have formed four-fifths of the majorities in our State conventions and elsewhere since the remion of the party from which Gov. Marey and Gov. Seymour have received support.

"Regarding the question simply as it affects the party in this State, I think it highly desirable and important that the occasion should be embraced to manifest that mutuality towards the radicals withont which the elements of a party cannot he kept in cordial or lasting union, and I think that, on such a question, the general sense of fair men is more wisely conformed to than disregarded. Certainly I do not mean to censure Gov. Marcy for allowing his name to be presented, or that we have any right or disposition to limit the range of selection by Genl. Pieree; but simply to state consirlerations which, in my judgment, are important in deciding the choice.

"This brings me to the question how the party in New York, as a whole, stand affected as between these two gentlemen? The radicals, who are a full majority in numbers and more in efficiency, are for Gen. Dix, and would, under the circumstances, feel some sense of exclusion in a choice of a different nature. Gov. Marey and his personal friends, though preferring him, cannot, as the case stands, make any actual oppesition to the appointment of Gen. Dix; and, if it he marle, will aequiesec-most, if not all of them, with cordiality. The considerations I have allurled to appeal strongly to their judgment and sense of justice, if failing to change their wishes; and with the relations which have grown up with many who are for Genl. Dix, secure this result. The opposition of the extreme ITunkers to Marey or Dix will be most manifest towards the one appearing most likely at the moment to be appointed; but I think that they are generally less repugnant to the selection of Dix, 
towards whom there is less of violence and bitterness in indiridual leaders. So far as this may be supposed to arise from the part Gor. Marcy took in promoting the mion of the party, I regard it as a merit; and for that, with a friendly construction of acts and motives, we have handsomely acquitted ourselves towards him. This animosity has other causes, among which is that he has been in the way of other gentlemen who have grown faster in their own esteem than in his appreciation (in which difference I think he is more right than they); and especially that Mr. Dickinson regards him as having, by being a candidate for the Presidency, kept that distinction from alighting on fitter shoulders-which it is certain that Mr. D. confidentially calculated the conrention would find, after trying Cass' awhile, to be of exactly his own management.

"Looking" to this State, therefore, I think the appointment of Genl. Dix would be the most wise, expedient, and prudent, with his moderation and conciliatory conduct always, and conciliatory disposition, it will prove generally satisfactory. Not that all can be pleased. Still less that a few impracticables in this city will be-who never have been for trenty years, when the party was strong and prosperous-T mean the leading spirits. 'Their idea of building up the party has been to exclude from it a majority as Barnburners, and the most of the Hunkers as having traitorous sympathies and affiliations with the Barnburners; and, incapable of more than one idea at a time, they have continued faithful to this, until they have pretty much exhausted the eredit they acquired in 1848 with the masses of those who roted for Gen. Cass; and have lost their influence in the organization of the party even in this city, while their crotchets are not and have not been shared in by a tenth of those who were nominally classified with them. They may be safely disregarded. There will be no local dissatisfaction in this city arising from appointments, if those which are of a local nature be judiciously made. The truth is the divisions and factions which appear on the surface of our city politics are pretty much confined to the petty leaders, and excite attention or interest in but a very small portion of the masses. They are generated by the very large number of offices, contracts, and other objects of cupidity, municipal, State, and national, which are concentrated here, and perhaps in some degree by the stirring and 
heterogeneous character of our population. They always exist, and have little to do with any settled general elassification. Their effect is to render' opinion and individual character less influential than in the more natural and sound condition of the rural districts, and to make the organization of the party, always serambled for to promote personal ends, a much less true index of the real sentiments of the party. So far as the relations of the aduninistration with the party in this city are to be effected at all by its appointments, assuming them, of course, to be intrinsically proper and reputable, it would be incomparably more by the multitude of little ones than by the large. While the appointments here should be made with primary reference to the honest and efficient discharge of official duties, a judicious care should be had for the harmonizing and conciliating the entire party. The one or two which have extensive subordinate patronage should not be surrendered to the bigntry of clique or of individuals on the idea of a partition between factions, but should be entrusted to persons who have largeness of views, judgments, and local knowledge enongh to administer the subordinate patronage on the same prineiple on which the administration itself acts. With such a poliey the disturbing causes will be reduced to a minimum and the party will move on in general unity and strongly ascendant. I will renture what character I" have for political judgment that no perceptible obstacle to this result would be found in the selection of Gen. Dix for the Cabinet.

"There is another consideration in respect to that gentleman. The is a model of a Cabinet officer. Able, accomplished, and judicious, capable of doing a given quantity of work in a speeified time, not having made himself or been made a candidate for the Presidency, he will serve the administration faithfully, and without aiming to control or manage it to personal ends: and being in nobody's way for the succession, with no affiliations formed to sceure it to him, not looked to with any such riew by those who present his name, he will draw on the administration no jealousies on that scole from those who fear passive not less than active rivals, and will not believe that Presidential ambition, once entertained, can ever be practically relinquished.

"To the force of all these considerations is opposed nothing but an alleged repugnance of the South or portions 
of it to Genl. Dix's appointment arising from his position in 1845. I do not suppose Genl. Pierce will be disposed to, or can listen to, an objection of this nature, and I think it will be found to have as little real existence as it has cogency. Mr. Dickinson's friends thought before the last eonrention that they should ruin Gov. Marey by charging him with having allied with the Barnburners; but it rather proved an element of strength, and the rotes he received were, notwithstanding, from the extreme South. Our friends there, as elsewhere, wanted a candidate who could win. Every man of sense, then, must see now that if the party would maintain itself, it must do so by the same policy by which it regained the ascendency. The real diffieulty in respect to the South will be in composing their own dissensions, in which all sides there will feel infinitely stronger interest than in any New York question. Such an objection to Genl. Dix may be entertained by bigotry or the narrowness of views of some, or more likely it may be the pretence of men dissatisfied on grounds interesting them personally. If this pretence be wanting to such, others equally available will be found.

"Whaterer it be, the sooner the administration shall show that it does not intend to reverse the policy which brought it into existence the better. Without a prompt, firm, and decisice course in this respect, we shall have nothingfrom cabinet minister down to tide-waiter-but discussions of past dissensions, which it is the policy and duty of Genl. Pierce, with all his power as the head of the party, to bury. It is a case in which boldness is the highest prudence. If the party cannot be kept large enough to contain all the great divisions of it which have predominated in powerful States or sections of the Union, it cannot be kept in the majority. In the face of the certain results of any other system, I feel courageous in supporting this, on the principle on which Moreau said he rendered his soldiers brave-by making them fear more to run than to fight.

"Asked the other day by a Hunker friend if I thonght it prudent to take a man of Gen. Dix's elass, I replied, most certainly to take one such. If past positions on the slavery question as it existed among Democrats, are to be the grounds of a classification, it is proper and necessary to represent the dirisions to which Genl. Dix belonged as well as others. Can it be done anywhere else as well as in 
New York? He will be in line with the majority of the party and the entire government in that State, which the minority of the party there, if that classifieation be the eriterion, will still be amply represented in other members of the eabinet, whereas if he he not taken, and the section to which he belongs be not represented elsewhere, as we may presume it will not, the results will be regarded by the country as a practical exclusion of that interest.

"It seems to be, therefore, desirable to take a man of Genl. Dix's relations; and to take one or more of the Statesrights Denocrats from States in which they stand with a majority of the party, and to represent the other great interests, as there will be abundant room to do, in the rest of the eabinet. A strong administration cannot be made by combining negations. If it be formed, as it should be, by men who have a predominant regard to its unity and success, the more its niembers have of the eonfidence and favor of the interests and States they are respectively taken to represent, the better. Of course I mean only men of qualifications and character, and of fitness in these respects and from their Democratic antecedents-and the objection to whom is merely the part they had in the recent Democratic divisions North and South. Let unfriendly erities, if they please, call such a eabinet mosaic. If the joiner work be good, as I believe it may be, and the materials be of the right general character, I do not eare how firm the texture or strong the colors of the parts. It will dovetail the party together for a basis on which the administration may stand securely. Certainly, I assume that in this there will be no violation of prineiple and honor to shock the eonfidence of the country. Those who think there is, and have acquieseed thus far, might feel some delieacy that their seruples arise for the first time when they are asking for themselves and on this ground a monopoly of the fruits of the wrong. Restitution to the true owner would be more becoming. If the party that elected Gen. Pierce be an alliance of those who 'annot honestly act together, it ought to be dissolved; but if it could honestly unite, there ean be no objection to proclaiming the intention to continue that union, or to carrying it ont in the most effectual way.

"At the late election, the large popular majorities as well as large electoral votes were in the great States of New York, Pennsylvania, and Ohio. Notwithstanding 
the clamor about the identification of Scott with Seward, the South did not do equally well, except in States where personal antipathies to that interest or personal commitments of Whig leaders produced systematic defections. No administration or party can stand without the support of at least two of the great free States. And the conceded abandonment at the outset of the canvass of either of the two largest, especially if it be the first in electoral votes, and of metropolitan action or opinion, usually loses one or both of the others. No man has been elected President against the vote of New York in the six successive elections since it has been cast unitedly and by the people; nor, indeed, ever but in a single instance, the circumstances of which scarcely constitute it an exception. Her vote has been often an unnecessary addition to his majority-and a hopeful contest for it would often enable the other States to do without her; but it is not easy to measure the force of her conceded or apprehended loss, representing, as her population does, elements that affect the equilibrium of so many other States.

"The interest, headed by Gov. Seward, which nominated Scott, is a powerful minority in these great States. Carrying almost the whole Whig party against an existing Whig administration and the influence of the great Whig leaders, it may, as an opposition and surviving those leaders, absorb the third party, now almost holding the balance of power, without disintegrating itself. It will be likely to try the experiment. The defection from it last fall, tho' encouraged by the commanding patronage of the administration and the name of Mrr. Webster, was scarcely more than one -certainly not two-per cent., and was confined to a few localities. If the previous State elections had not practically decided the contest, that defection would have been inconsiderable. Hereafter, not only are these disturbing causes stilled, but it will have the cementing influence of a common opposition.

"The characteristics of this interest, in our State politics, have been profligate jobbing and reckless enterprise and expenditure. The only effectual barrier to its predominance has been in the radicals. They include the prominent men who, with Wright, Hoffman, and Flagg, fought all our great financial contests; and a majority of the masses who maintained their measures, although large numbers of the 
latter were - temporarily, as I believe - detached by the divisions of $18+S$ and bound with the opposite interest about half of the entire party. While the questions on which they separated were oceasional and temporary, questions of honest financial policy and administration are ever present. Indeed, in our time the ehief political duty secms to be to protect the people from plunder under the forms of legislation and in the abuse of administration.

"On all these questions, as well as doctrines of States'rights, free trade, and in most general views of government, the radicals of New York (as I should have remarked while speaking of the relations between them and the Staterights Democrats of the South in a composite ealinet) sympathize with the radieal Democracy of the South; and, indeed, are the only unflinching coadjutors the latter have had in New York.

"Agreeing in what is the only safe reliance of constitutional rights, as well as the cardinal point of the Democratic faith-embracing, as each does, the flower of the Democratic youth, enterprise, and energy in its own region - withont discussing individual views of the comrse of either, antecedent to the general remion of the party, and armitting, if you please, that they are somewhat alike in the boldness with which they maintain their opinions, and repel aggressions on what they leem to be their rights-it is obvious that there are points of sympathy between them which make it easy and natmal for them to fraternize, when out of the presence of any immediate course of difference, as they did all throngh the late Baltimore convention and in its result.

"The radicals of New York include as much talent, courage, enterprise, and fearless devotion as can be found in any party. They have the advantage of being, on an average, lralf a generation younger than the other. These circumstanees, as well as those I have before mentioned, mark them as the future of the Denocracy of New York. Since Silas Wright's reath they have given their affections to no providential man. They fell into the support of Genl. Pierce with alacrity at the convention, and with generous enthusiasm in the canvass, becanse they reeognized in him qualities in common with those of their lamented leader, attested as well by the warm regard generated between them in former years by mutual sympathies, as by the whole career of the survivor. 
" As a matter of mere party calculation, I do not think it wise, with reference to the reconstitution and reconsolidating of the party on a comprehensive basis, to leave them the only large and powerful class not represented in the cabinet; nor, in undertaking to represent them, to pass over a statesman of great merit and in all respects unobjectionable, unless because he is one of their number. The administration will, I believe, ensure their support by its prineipals and measures. But looking to the eondition of domestic polities, in New York and the other great States on which the strength of the party mainly depends, I do not think it would be a mistake to add the cordiality that comes from a sense of equality and reciprocity in party relations and the energetic and efficient co-operation which will result. There are other considerations, but my letter has already reached an unconscionable length, my apology for which is, that writing my thonghts as they arose while writing they would not stop, and I could not-I have set them down frankly, not without some delicacy, at seeming so much to advise, but remembering that nobody need follow, while I would be unwilling to mislead. If I can contribute any information or suggestion to the general stock which you have a. right to advise, and He whose province it is to judge must needs gather from all quarters, my end will be attained. I am too sensible of the difficulties of filling up a cabinet on principles which seem essential, or any general principal and at the same time securing the highest individual fitness, worth and weight and a reasonable concurrence of our friends in the various localities, - to be willing to increase them. A just and firm policy will solve them, as nearly as is ever attainable in such cases, to the satisfaction of the country. With the best wishes of one who may speculate safely because he is without the responsibility of acting-and who, except as a citizen, a Democrat, and a friend of the new administration, has, and can have, no interest in the result, though not exempt from the influence of sympathies of opinion and association in attempting to take a fair view,

\section{"I remain truly your friend,}

(Signed) "S. J. Tilden."*

* To whom this letter was addressed does not appear, but there is every reason to believe it went also to Mr. Newell, through whom he conducted most of his correspondence with the Pierce administration. 
TILDEN TO FRANKI.IN PIERCE

"Confidential.

“ Hamisiburg, l'eb. 23d, 1853.

"Mr Dear Sir,-A little matter of business, which called me here for a day, has brought me again in contact with Gor. Bigler, and his impressions are so strong on a point I casually mentioned to you in New .York that I think it not improper to repeat his suggestion more formally. It is that, in ease you lave decided to take Mr. Campbell\% into your cabinet, you should, if practicable, put him in the Interior or Navy, rather than the Post-Office. The Gov. says the Catholies are very numerous in this State-enongh to make it probable that, in many instances, they may become candidates for appointment as postmasters - and enough to awaken little neighborhood jealonsies respecting them. He deems it undesirable that Mr. C., as the head of the department, should be called upon officially to decide on these cases, and be exposed to the suspicion of appointing from religious partiality, or to the necessity of doing injustice in order to aroid that imputation. It is worth considering whether these views have not more force than your own observation in the different condition of things existing in New England would indnce you at first to give them. In expressing them, the Gov. can have no motive but the welfare of your administration and of the party here, and his observation of the state of opinion here is entitled to a consideration. He seems to entertain these ideas so strongly, and so much to desire that they shall be presented to you, that I take the liberty of drawing your attention once more to them;-not to press them upon yon, but that your mind may pause upon them and take their exact measure before you conclude the question.

"I am not sure that my engagements will permit me to be in Washington at the inanguration; but I hope, at any rate, to have the pleasure of seeing you soon after.

"With great respect, "I remain, truly,

" IIis Exy. Franklin Pierce.

Your friend."

We have here a continuation of suggestions which Mr. Tilden felt called upon to present to President Pierce to

* Mr. Campbell was a member of the Catholic communion. 


\section{LETTERS AND MEMORIALS OF SAMUEL J. TILDEN}

guide him in his dispensation of his patronage in the State of New York. It makes one sad to think what an opportunity was lost by this President, and through him by the country, from his failure to sce the wisdom of this advice and to adopt it. Had Mr. Pierce respected the public opinion of the State of New York and properly recognized the political sentiments and sympathies of the majority there, as he did in the Southern States, the presumption is that the Nullification party would have been as effectually disarmed under his administration as it was by President Jackson a quarter of a century before. Franklin Pierce, howerer, was a different man from Andrew Jackson, and the conditions under which he received his nomination did not leare him a free agent.

It was only at this stage of Pierce's administration that Tilden began to indulge in the deplorable error of walking by sight and not by faith. He did not believe, nor did he ever again seem to comprehend, that in the slave States all other questions even the Constitution of our government and the integrity of our territory, were subordinate throughout the South to the preservation and extension of slarers; that every person who rentured publicly to express a doubt of the wisdom of allowing slavery to extend to the free Territories was pronounced there a suspect, and was proscribed as a persion who tainted every one who associated with him politically. The Nullifiers saw, and saw correctly, that the anti-slavery sentiment could only be resisted in America as heresy was resisted by Lonis XIV. in France-by crushing the heretics or driving them from the country. To reason with Pierce in favor of dispensing his patronage in the State of New York in accordance with the public opinion of the State, was as idle as the lambs reasoning with the wolf in the fable.

The following notes, though without address, were without doubt prepared by Tilden and addressed to Pierce or to some one for his perusal. By the paging of the MS., it appears that thirteen pages, which have not been found, preceded those which are here submitted to the reader. 


\section{LETTERS' AND MEMORIALS OF SAMUEL J. TILDEN}

ADDITIONAL NOTES ON TIIE ALLOTALENT

[OF OFFICES UADER THE PIERCE ADMINISTRATION]

"The Collectorship, the Sub-Treasuryship, and in a less degree the Naval Oftice, have State as well as city aspects. I have therefore set down the Secretary of State and the foreign missions in connection with them.

"Considered in a State aspect, see how much more the Hunkers (Hard and Soft) get, in every view of this allotment, than the Barnburners, who are more than equal in numbers and power to both of them mited.

"Considering the Collectorship singly in that aspect, the same result is obvious.

"Be not misled by the apparent predominance of the IInnkers in the city. Up to the moment of the schism in 1848 , the Radicals had five-sixths of the masses and nearly the whole party organization. Their old associates have been returning to them ever since. In 1851 the Radicals had a majority of the delegates to the State convention, and there was but a small majority against them in the General Committee of that ycar. At the last election of General Committee in 1852, they carried a majority; and at the last trial in the Tammany Society their majority was five to one. I grant that a large majority of the party went for Cass in 1848, but I do not think a majority are now in the learlership of Schell, Sickles, etc., or inclucled in the distinctive class of IIards. I entertain no doubt whatever, if the appointments are such as not to affect the question anyway, the Radicals will remain in permanent possession of the organization. The truth is that four-fifths of the rank and file follow the organization, by whicherel leaders it is wielded. All this, however, is matter. of opinion; I do not clain for it the assent of your judgment, although I have never been known hitherto to overealculate the strength of those among whom I belong.

"But permit me to say that this point is below the importance and dignity of the general question before you. The most controlling aspects of the case are State aspects and general aspects. If you vest the most powerful and influential trust in the State of New York in a politician of the most vulgar sort-or narrow riews, prospective in all save the promise by which that trust is sccured, a schemer 
for personal ends by desperate and fraudulent means, that almost revolted the party at the last eleetion-nay, if you fail to take most ample and certain guaranty against the predominance of any such influence, in the known, tried, and elevated eharacter of the man you select, your appointment cannot fail to be discreditable and disastrous in its results. You should rest that eorner of your administration on the sense and moral power of the community, by an appointment which should appeal to them, and draw approval from all disinterested persons. Do this, and you will rise above the altitude of mere politicians; and no disaffection which their disappointments will create can raise a ripple on the surface.

"There is one other consideration. I have recounted to you on a former occasion the series of surrenders by the Radicals to the Softs through which the Union movement of the New York Democracy has been thus far carried on. I could not adequately express to you the painful personal embarrassments by which its recent steps have been marked - the embroiling of old personal relations-and the diffieulties with which it has been achieved. These were our main motives to ask in the selection of a Cabinet officer from New York some recognition of the radicals. Again they yielded, and they have looked forward to the most prominent local appointment in the State as a case in which what they felt to be justice-long deferred-would be accorded to them. The impression-whether well or ill founded-has existed that such would be the course of things. I confess that I have shared in that impression. Instead of there being any cause for shrinking or hesitation, I think the occasion onght to be desired to fulfil an expectation so right and reasonable. I clearly think that it is needed. I know I speak the sentiments of the strong men among the radicals when I say that the personal interests, desires, or gratification of Gen. Dix, or any other man whom they have honored, are as dust in the balanee in the true sravity of this question. I believe Gen. Dix is the last man who would dissent from this opinion. At any rate, I take the responsibility of expressing it in the name of all his supporters.

"A clear, conspicnous recognition, in a case in reference to which expectation has [been] excited, and which concerns more than the gratification of a single individual, is what is neederl. The controlling men of the radicals in all 
parts of the Stale are independent men-in condition as in character. They are weary with debating questions of their own equality with the rest of their party. They have not proposed to proscribe anylorly. 'The question las constantly' been whether they should be proscribed. They do not rely on instructions contrary to the disposition and whole anterior conduct of the individual intrusted with the power. Such reliance would be an illusion inconsistent with all ordinary experience; and a choice which should inply it will utterly fail of inspiring confidenee or produeing any valuable effect.

"The programme should be aceomplished to this actual condition of facts and sentiments.

"It is with a clear sense and earnest feeling outrunning my power of adequate expression, in the haste in which I write, that I put you in possession of these ideas. I do so only because I think I comprehend the ease better than can easily be done from a distance; and beeause $I$ deem it important that you should he appraised of the sentiments of a powerful class on which the suceess of the administration, so far as New York is concerned, largely depends. A desire that you should do what is wise for it and for yourself is not less my motive than a desire that you should be just to the class to which I myself belong. I confide entirely in your disposition to do what is fair and right to all; and have a grateful sense of the kindness and consideration with which you have treated me personally. These very sentiments impel me to address you with earnest frankness in respect to a matter, a mistake in which eannot, in my judgment, be easily, if at all, retrieved.

$$
\begin{aligned}
& \text { "Very truly, } \\
& \text { "Your friend, "S. J. Tridden." }
\end{aligned}
$$

\section{J, VAN BUREN TO ISAAC FOWLER, POSTMASTER OF NEW YORE CITY}

“New Yolk, Mch. 2/st., 1853.

"Mr dear Fowier,-Yours of yesterday is reed., and I have read it to Kennedy and Waterbury, who have started to get letters-they feel confident that the Mayor will write; Dix is at Rye, but has written, I think, to Tilden. Havemeyer writes for nobody this day. I enclose a note of my 
own, which, with Marey friendly, ought to cover ground enough.

"I yesterday wrote O'Sullivan by Benton-also Temple; rou will have seen my letters before this. If I had known last week I could be of service I might have run on. Now I start for Albany at 1.15 , where I have 3 causes amongst the first 10 in the Court of Appeals, and they now have a rule that they will not strike off or reserve on the first day. If I can get away the last of the week I will run on to Washington, but then I suppose it will be too late. Tallcott came on with Tilden to Philadelphia, and brings accounts corresponding with those in your letter. If I had known exactly how matters stood I would not have alluded in my letter to Temple to my previous letter to 'Tilden; if he has not read the President my letter to him he may strike out that part, or say that Tilden was afraid the abruptness of it might not be understood, and so retained it. There is nothing in either letter that should be misapprehended between honest men-the President is entitled to frankness and plain-dealing, and so are we.

"In regard to my visiting. Washington, I see no good I could do, exeept to satisfy the President and Govr. Marcy that we mean to deal with them not only fairly but liberally. This ean as well be done by yourself, Tilden, Richmond, O'Sullivan, Crosswell, Temple, Cassidy, and any other friends with whom I have no secrets, and without whom I should be powerless, if disposed to differ from them. Marey must be perfectly aware of this, and I am sure the President is. I am not surprised to hear from all our friends that Marcy behaves well-his natural disposition, old associations, good sense, and obvious policy all combine to take him to the side of sound men, and if he is prudent the party can be made very strong in this State. It is curious, but true, that I have said from the first that the only fear I have about him is that he will be too violent on the hard shells! It is a singular fear for me to have, but it is because such a course would weaken M.'s influence with Pierce, and excite sympatly with the hard shells. That M. would be just to our people I have never doubted since he was selected.

"I left word at Dix's that I had named him for the Collectorship. I had some conversation with him about it the other day, and inferred from what he said he would not 
decline. On looking over the whole ground this seems to me the best thing the President can do-and I think Dix would be pleased with it. We cannot insist on a mission for him and the collectorship for a Barnburner. We must have the latter, and if Dix, after being gazetted to the Cabinet and to France, should get nothing it wonld be extremely awkward and almost ludicrous; this would mortify me extremely as well as him and his friends. I have been to see Haveneyer; he says he will not accept. I told him if he declined we would murder him. But it seems to me the President should choose between Kelly and Dix; if he can take Kelly and give Dix a mission that would be best of all. Write me at Albany, and telegraph if anything oceurs.

"Truly Y'rs, "J. VAN Buren.

"P. S.-If the President gives us a fair man for Collector, and the Navy only, he might put in some ITunker for Marshai, P.-O., Apprsr., Surveyor, etc., leaving room for Dix's mission."

\section{W. L. MARCY TO S. J. TILDEN}

"Private and confidl.

“WaSII., \& Apl., '53.

"Dear Sir,-The appraiscrs have been up, but I have got the appts. put off for a few days. Let me know who (you think) ought to be app'd.

"Dickinson is to be here to-morrow-and it is expected by his friends that he will interfore and have a potential voice in $\mathrm{N}$. Y. appts. What of 'Thompson for $\Lambda$ ppr. at Large? Redfield has telegraphed me that he shall aceept and come on here. Sce him if you can, as he passes thro' N. Y.

"Yours truly,

" VV. L. Marcy.

"S. J. Tilden, Esq.

"P. S.-Pomeroy is nominated as Appraiser at Large."

The aceession of Pierce to the Presidency was soon followed by the retirement of F. P. Plair, who had edited the 
Globe, a senti-official press since the inauguration of President Jackson, and by the establishment of the Union as the new administration organ, under the editorship of $\mathrm{Mr}$. Ritchie, the proprietor of the learling Democratic print in Virginia. This was the first ummistakable evidence of the deliberatively proseriptive policy of the new Cabinet.

Mr. Forney; who for many years had been the Washington correspondent of a Philadelphia print, was assigned to a prominent command on the skirmish-line of the allied pro-slavery press. Though not a wit himself, the following skit will warrant his friends to claim for him the credit of being once very nearly the cause of wit in another. Its chief interest to the reader now consists in its glimpses of many transitory political issues which only live in the daily press and private correspondenee of the period.

\section{PROSPECTUS OF THE " FORNET-CATERER"}

"A daily journel will be established in the City of New York under the title of the Forney-caterer, the first number of which will be issued Jan. 1st, 1854, or on some other first of Jannary.

"This journal will profess radieally Democratic principles. Believing in the largest liberty-especially in using the public moneys, it will insist on the extension of that liberty through all the domains of the public treasuries, national, state, and municipal, as the true idea of Democratic progress. It will be in favor of free trade, as practically illustrated in steamship contracts; and will particularly sustain the Sloo contract, and the assignment thereof to George Law, Edwin Croswell, Prosper M. Wetmore, and Marshall O. Roberts; and the Collins contract, which its editor will also personally advocate in the lobbies of Congress for a moderate compensation. Opposed to internal. improvement by the general government, it will urge liberal appropriations of the public funds to any private company which shall make satisfactory arrangements for grants in aid of the Pacifie Railroad; and will take a small interest in the purchase by the United States of the property of the IIndson's Bay Company, should that beneficent measure be revived with a prospect of suceess.

"In respect to the foreign policy of this country, it will 102 
be equally explicit. Asserting the honor and dignity of this great and powerful people, it will upholel the elaims of Messrs. IIargous with firmness, whether against belligerant or bankrupt nations or against refractory or uneonvinced commissioners.

"Located at the great commereial eentre, this jomrnal will aim to be metropolitan in its eharacter. Not inrlifferent to the concerns of sister States, it will take a largo interest in maintaining the Camden \& Amboy monopoly and other domestic institutions, the hlessings of which no traveller erer can pass a sister State without feeling.

"Strangers to the eity and State of New York, as the editor and founder of this journal both are, it camnot be expecter that they should at the outset act without hesitation in purely local matters. In respect to the offal contract and the Broadway railroad, and as to the canal lettings and the timber contracts of John C. Mather, it may be as well to say that they are, as yet, wholly uncommitted. They are, however, not altogether unfamiliar with similar things elsewhere.

"An ample eapital has been contributed by gentlemen who are interested in maintaining the great measures to which this journal is to be devoted; and no expedient has been onitted to ensure its suceess as a business undertaking in behalf of its stoekholders and managers. It will be provided with editors, reporters, and other attaches, enough to perform all useful services in the lobbies of Congress, of the State Legislature, and of the eity Councils; and with talent and democracy enough in the editorial rooms to make good the ordinary wear and tear of eharacter and influence ineident to the other departments of the business.

"As conveyancing will for'm a large element of the business, expert legal counsel will be provided in the person of Mr. D. E. Sickles, who is reeommended for this purpose by his rare skill in taling mortgages.

" Before conclurling, it is a painful necessity to advert to the unhappy divisions of the Democracy of New York, which it is the main object of this unlertaking to heal. An exact inpartiality between those who are for preserving the party and those who are for breaking it up, was intended to be secured by dividing the ownership of the paper equally between them, and then putting its absolute editorial control in the hands of a gentleman whose associations, sym- 
pathies, affiliations, and tendencies are entirely and irresistibly-with the latter.

"That equitable and sensible plan having met some nnexpected objection, it has been slightly modified; but it will nevertheless be earried out as if unchanged. The business arrangements are most profound and comprehensive. The proprietors who invest a large capital in the enterprise are to have no voice in its editorial management, because that department-the doctrines it maintains, the degree of its ability, its consistency, its integrity, in a word, its whole editorial character-is not supposed to make any difference with the subscription-list or advertising of a newspaper. The modern idea of a complete separation between those who spend and those who pay is to be earried out more fully than in any other joint-stock speculation heretofore known; and gentlemen of first-rate ability in both these departments have been secured. It is not doubted that the result will eclipse anything that has gone before it in the newspaper line. The editor will be paid a double salary for his shares and the sacrifice he will make in relinquishing a lucrative place in the House of Representatives, but without prejudice to his continuance in that post, to which he will be a candidate for re-election.

"The issue of this journal having been postponed from the period first announced, an explanation is due to the public. The paper had become deeply pledged to support the State ticket to be nominated at the Syracuse convention and the regular organization of the Democracy of New York, under the expectation that both would be in adamantine conformity to the principles herein avowed. The editor and founder and their associates were assembled in this city to await the issue of that body; and at the very moment of the bloody scenes of Syracuse were having recourse to the private perusal of the riot act, when, lo! they were themselves thereby incontinently dispersed, and cannot be at once reassembled.

"New York, September 19th, 1853."

\section{TILDEN [INCOMPLETE]}

"New York, Sep. 10th, 1853.

"T)Ear Sir,-Your letter was received yesterday. I do not think there will be any considerable difficulty in respect to resolutions. The general disposition will be to go to 
every reasonable extent to lisarm those who are predetermined to make mischief. The true and only serious difficulty is to get the eonvention organized. The plan of those who are hostile to the mion of the party is to have two conventions, if it be possible to confuse the public mind as to which really represents the party and its organization. All the moderation, prudence, and liberality consistent with the preservation of the convention must be exercised to avoid a disorganization; or, if that cannot be avoided (as it cannot be, if any consirlerable minority are bent on it), to leave the disorganizers with as little of a case as possible. The danger is in the large number of contested seats-real and pretended. In about half of the cases there is no sladow of claim on the part of the hard-shell contestants; and such cases can be multiplied indefinitely, so as to form with the extreme men in the convention and the contestants out of it a sufficient number to be a quorum of a separate body. I think we ean stand the large number of these now known, if the moderate and union Hunkers can be held, as we anticipate. I have heard from various sources that the President feels the same solieitude which your letter expresses, and that he thinks that the defeat of the party here would revive and reorganize the Whigs all over the country. In that he is quite right. On the encouragement of a disaster in this State, the Whig party would spring to new and full life. It was so in 1837 and in 1846, and in botl those cases the results spread over the whole country. Neither you nor the President need doubt that we are fully aware of the peril, both to the party in the Union and in this State; or that any reasonable effort will be omitted to avert it.

"But we are put to great odds when 30 or 35 of our districts are nentralized by eontested elaims, and in all this part of the State the mass of the patronage of the genl. government is used most unserupulously against us, and-"

\section{WILLIAM CULLEN BRYANT TO TILDEN}

"New York, Nov. 23, 1854.

"My dear Sil,- - T have called at pour office twice to-day on some lusiness of my own. Will you oblige me by letting me know when you are in your office, that I may come and bore yoll?

Yours truly, "W. C. Bryant." 


\section{S. J. TILDEN TO MARCY (PROBABLY)}

"New York, Oct. 12, 1853.

"Mr DEAR Sir, - I take the first moment I have been able to command to answer your note reed. on Monday.

"There is no truth whatever in the story that Grover* roted against or dissented from the resolutions of the late Srracuse convention. As the question was then taken vira roce it is foolish to say that any man actually voted for then unless you happened to see his lips move or distinwnished his roice, but as Grover did not express dissent or apparently reserve his vote, I suppose he must be deemed to have concurred in their adoption. I have no doubt that he did so, for in the caucus the evening before he was openly in faror of adopting the Baltimore resolutions. My own knowledge of his sentiments, as expressed before, correspond with this course on his part. I state this as matter of fact, because it is fact; and not that I do not think it idle to expect to silence those clamors in respect to Mr. Grover. They must have something to say. The conrictions I expressed to you as the true policy in respect to the collectorship would have been strengthened by subsequent events if they had not been before so clear and strong.

"The safe issue with Bronson was on the charge that he has lent his official character and influence to disorganize the party in this State, and to aid the formation of an organized opposition to the administration, and has abused the appointing power entrusted to him to accomplish those objects both of hostility alike to the Democracy and the administration. He wonld be easily convicted of the first charge by his orert act in taking part with the bolters from the character of the ticket he sustains and from the declarations of the body of his associates. Indeed, his practical position in that respect is already sufficiently recognized by the general public. The second charge that he had exerted his official influence and the appointing power to further the ends of the new combination into which he has openly entered wonld be readily believed, and its truth could be abundantly shown at leisure. These charges, if well founded, as they unquestionably are, are of a character to

* Mr. Grover had acted with the Free-soilers in 1848 . He was now suggested by Van Buren's friends to succed Judge Bronson as Collector of the Port of New York. 
justify and, indeed, demand of the administration, by its duty of self-preservation and its duty to maintain the 1)emoeracy as an organized party, to intervene for objects so important and so elevated. It ean act on such grounds without loss of dignity, and with a justice that is eapable of trimmphant rindication. That action should colrespond with the nature of the ease-the clear legal [obligations] of the Collector to the President and to the character of the administration. In my opinion such action is to be performed only in the exercise of the power of removal. The efforts of the administration to come to an annicable unclerstanding with this 'refractory subordinate,' as the Globe used to say, have all failed hopelessly. Any attempt to coeree his discretion while retaining him in oftice is ineonsistent with every attribute which onght to characterize the action of the administration, as the case now stands, and will entirely fail of results except to weaken and besmireh the administration itself.

"The failures to coerce his discretion, even his unfairness and his infidelity to the policy of the administration in the distribution of the subordinate appointments, are by no means the strongest grounds on which to place his removal. On the contrary, I think it a godsend that lie has furnished other grounds proved to your hands, of impregnable strength, on which to justify a removal made neecssary by petty wrongs and frauds, but now becomes at once indispensable at the hands of the administration and capable of being done withont loss of dignity.

"There is still another ground besides those mentioned where the movement in this State has for its avowed object to compel the President to remove his Cabinet. This object is daily manifest through the press and by speeches and by resolutions. The Collector has taken open part with this movement, and, while disclaiming these objects, he is fairly to be held to eonenr in them, and I presume nobrdy has any donbt that he, in fact, does so. He at the same time holds an office of most power and of nore importanee to the administration than any member of the Calinet. Now is it possible to suppose that if a nember of the Calbinet were taking part in publie meetings of nen, whose object was to expel the rest of the C'abinct, the administration conld omit to interfere in the nuatter without a total loss of all public respect? 'The principle that the heads of the 
departments should be in relations of harmony and confidence with the President has been applied as much to the Collectorship of this port as to the Cabinet offices, and with at least as much reason. Prudence as well as principle has always sustained the President through all change of parties and of individuals in bringing the chief officers of the government into this harmony with it whenever he has found them otherwise. These are the grounds on which the remoral of Bronson should be placed, and his unfairness and infidelity to the policy of the administration in appointments only incidental as constituting or being part of a systematic abuse of the appointing power to aid his general object. This latter should be rery incidental.

"It is important that the issue should be made on his conduct and in its moral, general, and public aspect, and not on the conduct of the administration in interfering with his appointments. It is important, in a word, that the administration should have the affirmative of the issue-that it should be charging the attacking party, and not the defending.

"You are now pausing on the edge of a marsh, when you should be in full march on solid ground, so at least it seems to me nothing remains but to recover as soon as possible a firm and stroug position.

"If Bronson answers at once, his reply will afford the occasion for an instant removal.

"In that event, care should be taken, by a well-considered and powerful article in the Union of a semi - official character to place the removal on the true grounds-and as little as possible on the one by which the correspondence will probably be used by him and by the Whigs to frame; and that article should be especially shaped to carry the war into Africa.

"If, as I fear, Bronson should delay answering in the knowledge that time lost is all in their favor and against us, there is one other resource. Let the administration treat the open avowals of our organized movement to change the Cabinet, which have been made since the correspondence commenced, as a new development of the designs and character of the movement with which Bronson is implicated, and as a new offence which calls for immediate action. I see no difficulty in doing this if the administration is really earnest for action instead of wishing occasion for tempor- 
izing. Take an aflimative, energetic course, and the details will work ont thenselves or be casily hronght into conformity with the broad grounds on which you act. The administration is perishing by slow discase, the result of indecision and want of energy. I do not say this beeanse I an willing to think it is the administration's duty to come up to any personal wishes or opinions of mine, but I should be blind if I failed to see the indication of a general and prevalent pulslic opinion.

"If you had not known me, and I have known you more than twenty years, and will not think I speak rashly, I wonld not speak so frankly, though it is at once the highest office and best testimony of ny friendship to eonvey early what is slow and late to reach the ears of men in power.

"The bolting movement in this State would have utterly failed if it could have bcen understood at the ontset that this administration were mited in discountenancing it. We should have earried the State, and the President's policy, wise and right as it was, would have had the double trimuph of carrying at once Georgia and New York, and faction would have been silenced in and out of Congress. The main force of the movement here has been the false pretence that it was favored by a part of them, representations of this nature being readily believed when made by local leaders in whom they have confidence. It is idle to say that enongh has been done to comteract this evil, when we are daily argned with by respectable men to show the contrary.

"But yesterday John Bowdish, of Montezuna, came to see me on the subject, saying that Thomas B. Mitchell has assured him that the President and part of the Cabinet were with the hards. I heard also from Putnam Co. that such is the general opinion there. It takes more time than there is before the election to penetrate the localities with the truth, and in the mean time men are getting eommitted too strongly to change. An mmistakable act at the outset would have saved all and would do infinite good yet. In addition to the general considerations respecting the character of the administration it is desirable [tle next three lines undecipherable]. Excuse the haste in which I write.

$$
\begin{aligned}
& \text { "Very 'Truly Your Friend, "S. J. Tindes." } \\
& \text { "S. }
\end{aligned}
$$


(This letter is obviously in answer to Tilden's last preceding.)

"Confidential.

"Wasm., Oct. 16, '53.

"Dr. Sin,-I received yesterday yr. letter of three sheets, and before I read more than one of them the President came in and interrupted me. The tenor of our conversation was such that I thought that yr. letter would be good reading-matter, and I handed it to him. Now, sir, if there is anything wrong in it - not fit for the Presidential eye, the fault will be yours for writing and mine for not guarding agt. yr. confidence in my discretion.

"Bronson's reply is not here, and fears begin to be entertained that it will not come. To tell you frankly what I apprehend, I am bound to say that it is possible there will be no decisive action before election if he does not reply; and perhaps none if he does reply, as I fear he will, that he has fairly divided his appts. among the sections, etc., etc.

"One thing I am much afraid of, and that is the comrse of J. Y. B. $*$ He told me at Albany that if the President did not stand by himself he would not stand by him, and, further, would denounce him. I have just opened a letter from him in which he intimates an intention to carry out this policy. If he does, you may depend upon it the cause will suffer beyond measure. I entreat you and all his friends to warn him of the fatal consequences of such a course. I have good hopes that things here will in the end be brought right-but I shall have none if he carries ont his nad suggestion. I beg yon will interest yourself in this matter. I see more mischief lowering in that quarter than in any other. I shall write to him, but my warning may not be much heeded.

"Hon. S. J. Tilden, N. Y.

"Yours truly,

IV. L. Marcy."

\section{HORATIO SEYMOUR TO S. J. TILDEN}

"Appleton, Wis., Aug. 8, 1854.

"Mr DEAR Sir,-I have been upon the point of writing to you for the past two months, but I have been constantly 
upon the wing. I regret I was not in this State with you. I travelled with Messrs. Corning and Delavan over this region; they were delighted with the crops and the appearance of the comntry. The wheat is now nearly gathered. The quantity and quality are unequalled by any previous larrest. I think it will give a new tone to affairs here. Your road is making good mogress. I wish it was done. It will be of great advantage to this section when the two lines are united. Something will be gained when the Watertown Road is reached. I hear this will be done in about ten days. We must make an united effort to get inmmigration turned into northern Wisconsin. It now goes to Iowa and Minnesota. $\Lambda$ few of the many thousands coming to our comitry from Europe would give life and riches to the region if they would come here. It is the best country for them. The Wisconsin roads make great efforts to earry them over the length of their lines. This carries the immigrants into other States. You and Mr. Ogden must devise a plan to correct this.

"I am very 'much disturbed about Secor's note in the Merchants' Exchange Bank. My losses have been very great during the past two years, but I do not like to come short of high honor in my dealings. I do not think I ought to pay the note, but I may be wrong. In my doubt, like most weak-ninded men, I have done nothing. I have no right to trouble you, but I must. I send you a letter from the bank. My continued absence from home has prevented me from answering it. 'This is another offence.

"Get me out of the serape in the way you think right.

"Very truly yours,

"Holatio Seyalour.

"S. J. Tilden, Esq."

\section{TILDEN TO}

"Newrort, (R.1.), Aug. 26, 185\%.

"Mr DEale Sir,-Your last letter reached me just as I was hurrying from the city to fulfil a business engagement at Lebanon. I partly wrote an answer while there, but left suddenly, and have not found another opportunity till I came here for a few days relaxation and sea-bathing.

"The address of my brother, for which you inquire, is 'Ienry A. Tilden, New Lebanon, Columbia Co., N. Y.' 
"In my former letter I did not write in respect to politics because I was very busy, tho' I would not postpone acknowledging your letter, replying to the business matter it contained. If that reason had not existed a sufficient one pnight have been that I had added nothing to the impressions I entertained when there was an opportunity of expressing them more fully. than could be done by correspondence.

"The truth is, the moment I return to the routine of my homelife there are, at present, so many business obligations and responsibilities claiming my thoughts and exhansting my activity that I could not, if disposed to do so, give much habitual attention to polities. It may be that, notwithstanding my necessary preoceupation, I should not aequiesee in so practical a retirement if I were able to propose to myself anything satisfactory which I could see a reasonable prospect of accomplishing in the present chaotic state of parties and polities. I have at least reflected enough, and discussed with others enough, to assure me that I cannot, at present, propose to myself any such thing.

"My opinions as to the promotion of a fusion party, whose objeet should be the restoration of the Missouri Compromise, have been more fully stated to you in conversation than they could be here, and have not been weakened by subsequent reflection. I do not think such a measure of any practical arail to rescue Kansas and Nebraska from slavery. Long before it could suceed, in the most sanguine view of its prospects, their destiny will be settled; and I hope that, through other agencies, it will be settled favorably. That being done, there is nothing in the Missouri Compromise which you or I would wish to have restored. This basis is not, then, broad or permanent enough to found upon it a party organization of much power or durability. So, I think, the public mind will regard the matter. Its action will be throngh the emigration societies, and to punish those whom it holds principally responsible for the breaking up of the armistice on the slavery question. In these modes Northern indignation will find complete vent, and will exhaust itself; and there will be another general calm. Nor do I now see any other kindred question able to change this result.

"In regard to bringing out Col. Benton as a Presidential candidate. He is very strong with the remnant of the 
old veterans of 1834 and 1810 , and has great general respect from the whole eomitry. But I have not changed the opinions formerly expressed to you in relation to his chances for 1856 . The Denocratic organization will run a candidate. If an organization, including the Northern Whigs, does the sane, I do not see how (ol. Benton could get an electoral vote. Presented, in the first instance, as an independent eandidate, it would require the eoneentration upon him of the whole body of the Northern Whigs to give lim any prospect of an election. Whether such a state of things ean arise, it is too early to foresee.

"I greatly regret Col. Benton's defeat in his distriet, but cannot say I am much surprised. The Whigs do not secm to have aided him mueh. When he ran before, denouncing' all against us, he was the novelty of the day. 'The Know-Nothings are that now. If he had been personally in the canvass it is possible he might have saved himself.

"So far as my observation extends in this part of the State, a third-party organization, if attempted, would not, in my judgment, cmbody a quarter of the force or numbers our movement did in 1848 . I do not know a man who bore any considerable share of the heat and burden of that day who would enter actively into a similar campaign now.

" A few who did comparatively little then might wish its labors repeated, if themselves exmpted. The general disposition among those most dissatisfied with the course of things at Washington is disgust, indifference, in some cases individual opposition, in many independent personal action; but very little towards organized, affirmative movement. They expect the Demoeratic party to be broken down for the time. They expect the folly of its leaders to inure to the benefit of the Whigs. Sone will look on with indifference; some will frame a ticket to suit themselves; some will, perhaps, aid to produce the pesnlt which all look npon as inevitable. Most will expect the Demoeratic party to rise again, purified, and to resuning relations with it. I know of none-tho' doubtless there are such individuals -who intend permanent mion with the Whigs. I know of few who would undertake the fornation of a new party outside of existing oreanizations. The body of those who went with us in 1848 will continue within the organization in which they have since acter." 


\section{LETTERS AND MEMORIALS OF SAMUEL J. TILDEN}

\section{TILUEN TO}

“N. Y., Sept. 5, 1S5\%.

"Mr DEAR Sir,-I did not think I shonld desire to be at the convention; but as the time approaches, I suppose that, if it were possible, the knowledge that you and some like you are to be there would eall me once more to commune with you. But all snch uprisings of the old spirit are quelled by a round of engagements here to which I must attend.

"I do not suppose that in the doings of the convention I can be entirely pleased-perhaps no one man will be. I cannot judge, as well as you who are present, precisely what should be done in a state of things at once so chaotic and so complex; and I have great faith in the wisdom that comes up from the counties. It seems to me, however, that there is more not to be done than to be done. It is a safe rule in affairs-and not less so in mere declarations that simply commit you without producing any practical result - that when you are in donbt what to do, do as little as possible. There is nothing to be achieved in this campaign but to preserve, as far as may be, the connections and harmony of the radical Democracy - a confederacy of men that has done some public service and is worth keeping."

\section{VAN BUREN TO S. J. TILDEN}

"Lindenwald, August 3d, '55.

"Mr dear Tilder,-T regretted not to see you during my short stay at New York, but was happy to hear that you are about to do what you ought to have done long ago, and if the young lady I had the pleasure to see at Rome is the happy fair one, yon have my ready and hearty consent.

"I am engaged in putting my honse in order, and will thank you to hand me a statement of my affairs in your hands and the papers by the first convenient opportumity. "In haste, "Very truly yours,

"S. J. Tilden, Esq. MI. Van Buren."

\section{S. J. TILDEN TO}

" New York, August 23rd, 1855.

"Mr deAr Sir,-After I received your letter, some three months ago, proposing to confess judgment to the Bk. of 
North America for the note due to it, I saw Wm. Henry, who desired ne, if possible, to get the matter postponed, in order that some different arrangement might be made. I applied to the bk., and they consented to some further delay, willing to receive part payment and to renew the residue. But no plan of that kind having been acted on, the bk. has been laterly speaking to me cvery time I meet its ofticers, and urge some proceeding so strongly that it camnot be further delayed.

"The bk. prefers an action which may bring in all the parties to a confession of judt., and I have had Mr. Green take the proceedings to save any unnecessary expenses. A copy of a summons and complaint is sent, with an admission of service endorsed, which you will please sign and return.

" $A$ t the same time, I cannot forbear expressing my regret that the matter has not been put in a shape which would render this course umneecssary. Persuaded in this instance, not withont great reluctance, to violate the rule on which I habitually and almost without an exception in my whole life-act, and which requires me to refuse all endorsements and suretyships-I feel that I ought to be prevented from annoyanee from this transaction. If I have submitted and am submitting to have the trouble and care growing out of the affairs of the company thrown upon me most disproportionately, it is simply from a friendly disposition, as far as I can within any bounds of reason, to see through a matter in which my friends are involved, and at least to get it in the best shape I may for them. From the beginning I resisted connecting mrself with the enterprise, into which I was, nevertheless, drawn; and exeept, for the considerations mentioned above, I would dismiss the affair from my mind forever. Under the cireumstances, it is not strange that I feel that the trouble and care thrown upon me thro' my regard for the interests of friends should not be added to by their omission to take care of their confidential paper.

"Mr. Green has reeently spent some days in Vermont in making investigations into the eiremustances under which the Stark Bk. hecame the owner (if it is so) of your acceptance. The results are very satisfactory. It will be necessary to nuke some additional inquiries of the corresponding biuns. I think we shall be able to show that the Stark 
Bank took the paper for antecedent debt which will dispose of their claims effectually and forever.

"Authority has been given to Mr. Thompson to sell $1,000,000$ of the bonds, as W. H. \& Co. is dissolved.

"Very respectfully, "S. J. Tildenn."

\section{S. J. TILDEN TO}

"New York, Aug. 26th, 1855.

"Mr DEAR SrR,-My name having been connected by some of the delegates with a nomination by the Democratic convention for the office of Comptroller, and in the public journals with that of Secretary of State-it is due to those who may do me the honor to think of ne for either of these distinguished trusts that they should not be allowed to be under any misapprehension as to the true state of the facts. The old friends whose names I see on the list of delegates will recollect that $I$ have never permitted personal feelings or taste to govern my political action, or been wanting in deference to the general interests or judgment of my associates; and will do me the justice to believe that I act in the same considerate spirit when I say that obligations which I am at present under and have no right to renounce are, in my judgment, ineompatible with my undertaking properly to diseharge the duties of either of the offices mentioned. As I do not deem it eonsistent with propriety to be nominated for either of them under such eireumstances, you will do me the favor to communicate this determination to any of my friends who may be disposed to present my name to the convention, and in ease of its being so presented to withdraw it from the consideration of that body."

JOIIN B. MILLER, WM. CASSIDY, TIIOS. G. ALVORD TO TILDEN

"UTiCA, Sept. 8, 1855.

"Srr,-Pursuant to the direction of the convention of the Demoeratic party of the State of New York, assembled at Syracuse on the 29th ultimo, the undersigned were commissioned to notify of their nomination the various eandidates recommended by the convention to the people for election. The delegates convened, as above stated, have signified their unanimous desire that the votes of their constituents be cast for your name at the coming election for 
the oflice of Attorney General. The Demoeracy of the State await an official ammonncement of the aeceptanee of the candidacy from those "pon whom the choice of their representatives has so satisfactorily fallen.

"With great respect,

$$
\begin{aligned}
& \text { "Join B. Milder, } \\
& \text { "Wm. Cassibr, } \\
& \text { "Thos. G. Mlvord. }
\end{aligned}
$$

"To Hon. Samuel J. Tilden, New York."

\section{TILDEN TO DEAN RICIIMOND}

"New YorK, Sept. 9th, 1855.

" MY DEAR Richuoxd,-I expected to find you here yesterday on my return from Lebanon, where I had oceasion to go on Sat. But I suppose you stopped at Albany.

"Since our conversation I have thought over the question of my rumning for Atty. Gen. The ground you put it on-expediency for our friends, without much prospect of sucecs to me-is not one which makes it easy for me to decline. I conld not render that reason or, with such friends as you, act on it while rendering another. Nor do I, in truth, eare much for any eonsequences $I$ can conceive as resulting from defeat. But I an worn from overwork. I have upon my hands now more than I can do for the next six montlis. And if upon the ticket I shall be expeeted to share in the canvass more than will be possible, and subjected to those special annoyances that are peculiar to a candirlate residing in this eity. I therefore greatly desire that you should make up the tieket so as to let me off."

“New YoRк, Sept, 11, 1855.

"Gentumen,-Your letter" appraising me that the recent Democratic State Convention 'have signified their manimous desire that the rotes of their constitments should be cast for " iny" name for the oftice of Attorney General," has been reecived.

"In accepting their nomination thus tendered, I acknowledge my deep sense of :m honor, conferred by a convention in which was assembled so much of remarkable and varied abilities, of political virtue and personal worth, and enhanced by association with a ticket which, in my judgment, will, if elected, eonstitute a working body, eapable of acting 
with unity, wisdom and effect, for a restoration of the honest and wise policy indicated by the convention, and for $r e^{-}$ establishing good government within this State."

"With great respect, gentlemen, I remain,

$$
\text { "Very truly, yours, \&e., }
$$
"S. J. Tillden.*

“Messrs. John B. Miller,

"Wm. Cassidy, and

"Thos. G. Alvord, "Committee, \&c."

\section{TILDEN TO -}

"New York, Dec. 28, '55.

"MY dear Sir,-Your letter in answer to mine in respect to your debt to the Bk. N. A., on which I am endorser, came to hand. It was not what I supposed from your previous assurances $I$ had a right to expect, nor what seems to me just. Whether it be even wise for yourself, I will not undertake to judge.

"An endorsement made for a man's aeeommodation is called confidential, because it is supposed to impart a very high and sacred obligation to proteet the friend who incurs such a liability in your behalf and for your benefit. It was a departure from my usual habit and settled rule, wrung from me by the importunity of friendship. With a good deal of trouble to me, it has been deferred from time to time at your instance, and in the last ease with a strong assurance on your part.

"You must pardon me if I say that I am not advised of any circumstance that can excuse the failure of so high an obligation. I have no reason to believe that an absolute inability exists.

"You allude, in this connection, to other liabilities hanging over you; by which, I suppose, you mean the claim on the drafts held by the Stark Bank. I should think that if anything could add to the obligation to protect me from a liability on your eonfidential paper, it would be that I have been engaged, and am still, with infinite care, labor and trouble, in trying to reseue you from that unjust elaim-

* For the history of Mr. Tilden's nomination to the office of AttorneyGeneral, and of his correspondence with Mr. Sutherland, his "Hardshell" competitor, see Bigelow's Life of Tilden, Vol. I, p. 127-130. 
that the intricacies of the case, the eomplexity of the transantions ont of which the claim grows, the witnesses being out of the State-" [The rest wanting.]

\section{VAN BUREN TO MOSES TILDEN*}

"LiNdenwald, septr. 1st, '56.

"MY DEsl: Sir,-T am happy to find that the "sober sceond thought' has brought your to the right conclusion, as I was quite sure it must do. I may add, too, that I homor the scruples by which you have been embarrassed. It requires no small share of moral courage for men of our antecelents to keep the posts of right and duty against the influenee of such resentments as we have been exposed to. But it would have been a erying shame to have had a single link broken in a family so pre-eminently Demoeratic as yours has been-from Dr. and Mrs. Younglove to Sammy.

"We are not only right, lut the erisis is, in my judgment, the most imminent and critical of any we have ever experienced. That mion should so long have been preserved in a confederacy which contains an element of discord of such magnitude and of so disturbing a nature as that of slavery, is a wonder-more surprising than its dissolution would be. This has been owing to the faet, I firmly believe, the single fact that there have always been neutralizing considerations of sufficient force to maintain party eohesions between men of the free and slave States. Slavery questions have from the beginning had more or less to do with our political contests, but have never before had the effect of dissolving old party connections and sympathies, and the balaneewheel has thus been preserved. Now, for the first time in our history, one side, and that the one in which we reside, las undertaken to earry an election, including the control of the Federal govermment, and against the mited wishes of the other. It has placed itself in a position which, for the first time euts itself lonse from all hope, if not desire, of assistance in the slave States. It not only admits that this is its position, but avows that it is a desirable one. It wishes to aceomplish its mastery by its own unaided arm. Now, it needs no ghost to tell us that one suceessful effort of this deseription will be followed by another, for men have too much the yuality of wild heasts in them to stop the pursuit

* Governor 'Tilden's eldest brother. 
when they have once tasted blood, and it would be against reason and experience to expect a Union, in which political mastery is so plainly exhibited and organized, to continue. From this evil we have been saved by the state of parties which hitherto existed, and to this danger are we exposed from the new and extraordinary thing which has taken the place of it.

"Slavery agitation must be eradicated in some way or another, or our institutions cannot continue in their present form. I was so indignant against the repeal of the Missouri Compromise that I could not do justice to the Kansas Organic Act, as that was the instrument by which the outrage was perpetrated. But I am now satisfied that if Mr. Pieree had from the beginning taken the stand he now seems to be taking, and interfered against all foreign interference the moment he saw the disposition to interfere, of which he had at least notice in the movements of the Missourians, the country would have been saved from the disgrace to which our institutions have been exposed in the estimation of the world, Kansas would have been a Territory so decidedly free as to put an end to attempts to make it a slave State, the country would have been quiet, the party united, and he renominated. All that is now wanted to secure many of the most important of these results is a rigid and effectual execution of the Kansas Organic Act. Although I am not a particular admirer of Mr. Buchanan, I have reasons that satisfy my mind that he will, if elected, secure to the country this great advantage, and therefore, and because he is the regular nominee of the party, I should vote for him. If I did not think so I would not go to the polls. I do have a very farorable opinion of Col. Fremont personally, but cannot for a moment doubt, from his utter want of experience in the affairs of government, and his inexperience in everything that belongs to it, that he would, if elected, inevitably be thrown into the hands of Seward, Greeley, and Weed, and I do not think the diffieulties in Kansas could be brought to anything like a satisfactory result through such agencies. I, on the contrary, think there is the greatest reason to fear that to commit the power of the government into such hands, at a moment so critical as the present, would be but "the beginning of the end' in regard to the confederacy. There are, I trust, few Democrats who would like to subject to their control and 
to the plundering propensities of their followers, the treasury, much less the governument itself. Our friends who think they ean go with the so-ealled Republicans this once and then return, make a dangerons experiment. Their party has always been a bourne from whence very few Demooeratic travellers have ever returned. The reasons for this are numerous and too obrions to make it neeessary to detail then. They lave, therefore, but one of two eourses to pursue-that is to trust to the Democratic nominee and the eonservative characters of the Democratic party, or to fly to evils they know not of, save only that except upon a single point, out of a great many, they cannot even hope for favorable results.

"But I must stop. This is the first private letter I have written about the election, and it will probally be the last, and nothing but ny very great respect for yourself and your race, and my desire to preserve their Demoeratic consisteney, conld have induced me to write this. If it gets into the newspapers I would leave no stone unturned to have you pmished.

"Üpon the subject of your last inquiry, I do not possess definite knowledge. I believe no final resolution has yet been come to. But I ean tell you nothing eneonraging. If ancient Federalism gain its long-lost ascendancy in that quarter, as it is so apt to do one time or another, I should give up judging of character.

"Remember me very kindly to your nother, sister and brother, and believe me,

"Moses Tilden, Esq."

$$
\begin{aligned}
& \text { "Very truly, } \\
& \text { "Your friend, } \\
& \text { "M. VAN Buren. }
\end{aligned}
$$

\section{W. L. MARCY TO TILDEN}

"Confidential.

"Wasmington, 8th Oct. (1857).
"Dk. Sil,--The course by leller having been taken, an instant removal camnot be effected. I have pointed out the error, but there is now no help for it. Renoval is the objeet aimed at and intended to be reached eirenitously. After a long eorrespondence the thunder will be used, and it will be said it is used beeanse worsted in the argument. 


\section{LETTERS AND MEMORIALS OF SAMUEL J. TILDEN}

"I believe most of the Cabinet were for bold action. I have pointed out very elearly the equivocal position in which the administration now stands and the disrepute into which it is fast falling, and have showed the only remedydecisive action. The Prest. sees this now as plainly as anybody, and is willing to apply the remedy. I have endeavored to convince him that he is missing the very best oceasion for using it.

"Some impression has been made on the mind of the Prest. as to Grover. It is said that he was opposed to, and did vote for, the resolutions at Syracuse. I hope there is no truth in this allegation, for if there is it weakens our position very much. A bolt from a Free-soiler will be easily exeused. It will be awkward to punish men for not voting for a ticket-regular though it be-if it is tainted with Free-soilism. The bolters are laboring hard on that point. Let me know if there really is anything wrong in this matter.

"Yours truly,

"W. L. Marcy."

S. J. TILDEN TO MESSRS. KNOX \& MORGAN

"Gentlemen,-If your note means that your elients withdraw from the proposition to allow us 1000 tons of rails, besides the 2470 bars, you already know what my answer must be. Every negotiation has contemplated the yielding of that amt. for the purpose of finishing the road to Oskosh. Your elients must think I am disposed to trifle or be trifled with if they suppose the way to agree is to recede from all that is most essential in their own proposition and in the basis of every negotiation.

"I am not quite pleased with myself (if it is my fault) that I have spent so much time so fruitlessly.

"All that remains - if your clients adopt and persist in that purpose-is to decide what you will do in respect to the application for the remission of the forfeiture of the iron at Milwaukee; whether, thro' your counsel there, you will aid or embarrass it. That application eannot be much longer delayed. We shall make it, and do our duty fairly, knowing at the same time that you have a greater interest than we in our snecess. If you choose to act adversely or not to neutralize your counsel, or not to aid, you must bear 
in mind that every opportunity has been given you to do what is reasonable and wise. I should like some understanding on that subject soon.

"Very respectfully, "S. J. 'Tildonn.

"Messrs. Knox \& Morgan, "43 Wall, Dec. 18th, '57."

TILDEN TO IION. GEO. WEIR

"NEw Yonk, Mar. 2d, 1858.

"Mr Dear Sir, $-\Lambda$ bill has been sent to some member" of the eity delegation by Mr. Green (who is absent for a few days), the nature and objects of which I wish to explain to yoll.

"Vessels were formerly repaired by careening them, afterwards by drawing alongside or suspending to them stages; afterwards by drawing them out on ways. The railway, acting by hydraulic foree, was the next mode by which repairs were effected. Some 16 to 20 years ago floating docks were invented and brought into use. They have gradually superseded all other modes; and vessels have increased in their size, until there are now no other means of coppering or repairing them than these floating docks.

"Of their utility and indispensable necessity there is no question. The commerce of this port could not get on without them.

"They have, sinee their first invention, been located in the waters of the East River, adjacent to the 7th Ward. The propriety and legality of their use of the basins (with the consent of the parties entitled to receive wharfage) has never been disputed until last year, when some parties proceeded against them on the ground that they are unlawful obstructions of the public waters.

"Judge Ronsevelt made a decision which, if well founded. goes the length of holding that this commereial use cannot be lawfully earried on or enjoyed in any of the slips, or at any wharf or pier of the eity, and in the opinion which he pronounced on that oecasion he recommended an application to the Legislature to supply the technical defect of the law.

"This is the oljeet of the bill. It legalizes the use, with the consent of the pier and wharf owners, and subject to the 
power of the Common Council to regulate and fix the location.

"The bill is right in all respeets. I take great interest in its passage, in behalf of the company I represent, the stockholders of which are owners or consignees of two-thirds of all the shipping which comes to this port, as well as on account of the general commercial interest. I will regard your aid as a personal favor.

"Hon. Geo. Weir, Albany."

$$
\text { "Truly Yours, }
$$

\section{MARTIN VAN BUREN TO S. J. TILDEN}

"Providence, June 16th, 1858.

“Mr dear Sir,-I waited for you till nine o'clock and then retired to secure a good night's rest, a matter of no small importance to a man of my age. I have no recollection of putting the charge for the box and cartage on my note, and think the chances are two to one that I omitted it; $I$ therefore send it now. When I am gone I trust you will, as my confidential representative, be more punctual in the performance of your engagements.

"Very truly yours,

"Mr. Tilden." "M. Van Buren.

\section{MARTIN VAN BUREN TO TILDEN}

"Lindexwald, June 29, '58.

"Mr DEAr Sir,-Mr. Brooks had arrived when I reached home, and I beg you to accept my best thanks for your attention to the matter, to me one of decided importance. As one good turn deserves another, especially when it is a particularly good one, I beg the farther favor of you to stop at Stamford \& Storr's and buy me a set of Scott's Family Bible for family use. They will cost from $\$ 10$ to 15 for the 8 volumes. If you can get them cheaper and better anywhere else that is convenient you will, of course, do so. I have hitherto troubled Mr. Butler* with these matters, and there has not been one which would have given him more pleasure, but he is out of town and his mantle falls on your

* Who had been Atty.-General under Van Buren when President. 
shoulders. I dare not trust John, as he would ruin me by the price, particularly as it is to be a present.

"Present me very kindly to your mother and sister if they are yet with you, and believe me,

$$
\begin{aligned}
& \text { "Ever truly yours, } \\
& \text { "il. VAN Bures. }
\end{aligned}
$$
bill."

"Send by express, and let the bookseller send me the

\section{TILDEN TO MR. CASSIDY}

"New York, Jan. 6th, 1859.

"Mr Dral: Cussiny,-I was so oceupied at the time I reeed. your letter that I did not get a chance to answer it before the election, and sinee that time I have been in an ice-pack of engagements which aceumulated around me in a ten-day's' career as a politician.

"I sympathize entirely with your feelings in respect to our friend Chureh. I do not know whether your suggestions applied only to the contingeney of my election as counsel to the corporation. Even if they did, I should be happy to see him, and, if there is anything within my power remaining-to serve him. I have just returned from Phil. and write withont your letter before me."

\section{VAN BUREN TO TILDEN}

“Lindenwald, Jany. 19th, '59.

"Mr DE.ar Sul,-Accept my thanks for the Cicero, which I have read, after cutting the leaves and placed with your books. Will return it prepaid. Now, upon the time-honored prineiple that one good turn deserves a great many, I go on. I have $\$ 10,600$ dollars of Erie bonds, seend nortgage, and I presume they will be paid on the 1st of March. I wish to seek a place for a new investment; have the goodness to let me know whether there is any doubt of it.

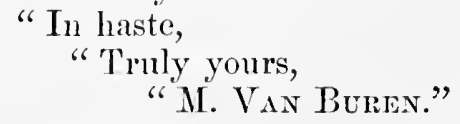

M. VAN BUREN TO TILDEN

“ Fishigl Landing, October 1', '59.

"Mr dear Mr. Thlden,-I am here on a visit to Judge Kent; intend to renain till Monday, then go to Mr. Jíem- 
ble's, remain there till Wednesday or Thursday, and then go home. I left John at Lindenwald, suffering from a slight attack of the liver, which I thought required attention, and with considerable difficulty extracted a promise from him to remain till Monday of next week, and avail himself of Mr. Pruyn's advice; as an inducement, I promised him to ask you to come up and spend a day or two with us the latter end of next week. Can't you come? Take the whole the week after Thursday, or, if necessary, Wednesday to Friday. Perhaps Saturday would be the least inconvenient to you, and to come down with John on the Monday following. I am particularly desirous to see you, as I wish to have some conversation with you on a subject in which my feelings are deeply enlisted. Drop me a line here, if you can, and if not, at Coldspring, informing me of what you ean do. The sooner the better, as I would like to inform John so as to assure his inducement to remain.

$$
\begin{aligned}
& \text { "As ever, } \\
& \text { "Truly Yours, } \\
&
\end{aligned}
$$

TILDEN TO M. VAN BUREN

THE MAYORALTY ELECTION OF 1859

“ New York, Dec. 25, '59.

"Mr dear Sir,-I wish you a 'merry Christmas!' It is the first opportunity I have had to acknowledge your kind letter of condolence. I take it up first of a bundle of letters which have waited for me to get out of the ice-pack of engagements which collected around me in ten-days' career in politics. I am just ill enough to be justified in declining all dinners, and an having a quiet time to-day.

"If your curiosity to know the "whys and wherefores" of our defeat is not displaced by some later topic, I will drop you a hint or two towards a theory.

"A moderu invention practised in Tammany Hall is for the genl. Committee to dispense with primary elections. It was introduced by Wood and has continued since he was driven out. The effect of two or three year's' practice under the system has been to break off relations between that body and the masses in the wards. It was no longer necessary for the one committeeman and his four dummies, who represented a ward in the committee, to keep up a vital party 
in his ward. The ward committees fell into disuse, and in some cases what remained of them were in hostile hands. Meanwhile the outsiders felt that they had no ehance, and antagonisns were multiplied.in all the captains of tens and fifties-the new men, the active elements of fresh ambition. The chiefs of the general committee beeame totally bankrupt, were split into two parties-abont equal-liad been occupried for months in a sentle for the assets, the real value of which they did not see till the last moment. In a party twice as large as any it had to contend with, and therefore tending to division-witl its central organization in this condition, and its ward all rum ont - Wood hung up his sign over the outsiders. He made loeal organizations among then; worked at it assidnously for two years. When I stepped inside the ring and took a view I thought that in some wards, each having once and half as many people as your county contains, we should scarcely have machinery cnongh to run our ticket with-the 11th, for instance. We had less than two weeks to get up our organization, beginning anew-in a bad state of local nominations, many of the candidates running on both tickets and being really against us. Wood had gained the lower stratum of the Irish, combined many special interests, and at last had the aid of the jobbing Republicans, two of whom voted for him to every one of the other class for Havemeyer. Then the Tribune, in bad faith, and the Post in good faith, succeeded in making the impression that the way to beat Wood was to vote for Opdyke; and not only kept the moderate Republicans to him, but drew many quict eitizens who preferred Havemeyer, but were most anxious to beat Wood.

"In truth, the leaders of the Republican party and IVood were in perfect concert, as they are partners in the gigantic schemes of phunder, which will presently appear.

"Mr. Havemeyer polled a prodigious vote of the business classes and of the silent people, but not enough to supply the defeets of the organization which, in my judgment, lid not by its own strength give him 15,000 votes.

"Enongh of this. I should not have gone over the ground except for the curiosity yon expressed-that what appeared to be an immense public opinion was ineffectual. It is a public opinion with a party, and not without, that sweeps the stakes.

"For myself, while I am quite aware how different is 127 


\section{LETTERS AND MEMORIALS OF SAMUEL J. TILDEN}

the prestige of success from defeat, and how great was the part which might hare been attempted in reconstructing the administration of the government of the city, I cannot but feel more comfortable as I am. The proper duties of the oftice are one thing. A joint tenaney in the administration of a city like this (if you really attempt to do anything); a reconstruction of its govermment, which must be made from the very foundation, in order even to palliate existing evils, is a different matter. Orerworn as I am with some heavy engagements, from which I cannot retire, yet uncompleted -and some heary cares unrelieved-I could not help seeing the burden more than anything else. This may have been morbid. A little more strength and health might have dispelled it. But it enables me to accept the result with a sense that a great trouble is off my mind, and leaves no personal regret to mingle with the disgust I feel at Wood's election, and the disappointment and injury to our friends. At present, I am eontent to live from hand to mouth, and take no thought for the morrow.

"Notwithstanding" your invitation to discuss the matter, I feel some excuse necessary for a letter that has grown so long and so personal.

"With my best wishes for your continued health and comfort and progress in the work which enlivens your retirement, and my kind remembrances to Mrs. and Miss Van Buren,

$$
\text { "I am, very truly, your friend, }
$$

"P.S.-I had almost forgot to mention that the prospect now is that you will get your end paid in full. I should take the money."

The two succeeding communications to N. H. Swayne, afterwards one of the judges of the Supreme Court of the United States, are interesting from their giving a sketch of the preliminary but comprehensive preparations for the rescue and reorganization of the Pittsburg, Fort Wayne \& Chicago Railroad during the early days of the Civil War, and transforming it from a bankrupt corporation into one of the most prosperous highways on this continent. It is doing injustice to no one to say that it was mainly through 
Mr. Tilden's devotion, sagacity, professional ability, and foresight that this transformation was so successfully aceomplished.

TILDEN TO W. H. SWAYNE

"Feis. 10,1860 .

"Mr DEar Sir,-It being designed, if possible, to provirle for a reorganization of the Pitsburg, F. IV. and Chicago R. R. Co. during the present year, such legislation as is neeessary should be obtained at the present sessions of the Legislatures of Pemm. and, Olio. That would be expedient even if we were to wait for legislation in Indiana and Illinois until next winter. Bnt I do not think it is necessary so to wait. I suppose that a corporation created by one of the States in which the road is situate, if endowed by the law of its creation with the capacity to exercise its functions in the other States, may hold and operate the road in those States if the sovereigns there will allow it to do so. I suppose that express permission is not necessary. It may do so on the principle of comity, mnless prolibited by the legislation or declared public policy of those States. It may still be prudent to get the assent of those States declared legislatively. The act which governs the constitution of the corporation may be obtained in Penn. That will avoid any question as to the operation of the clause of your constitution imposing a personal liability upon stockholders. In Indiana there is a general law adequate to enable us to reorganize a corporation of that State. Its Legislature, like that of Illinois, does not meet till next year. There is nothing in the statutes or dreisions of Illinois to prevent a corporation of Penn. or Indiana from holding and operating a railroad in Illinois. I presume there is not in Ohio, but that I luave not investigated, as it is wiser to have an act of recognition. In Penn. the statutes of mortmain exist by judicial adoption, and no forcign corporation can hold real estate there withont express permission.

"We propose, then, inmediately to get what we can, viz., a parent act from Penn. and an act of reconition from Ohio.

"The act for Penn. was finally agreed npon hetween $\mathrm{Mr}$. Camplell and we yesterkay, and was taken by Mr. Ogden to Mr. Cass to be passed. I will send you a copy as soon as I get onc.

"I have drawn and send helewith what I deem to be a $1: 29$ 


\section{LETTERS AND MEMORIALS OF SAMUEL J. TILDEN}

suggestion towards the bill proper to be passed by your Legislature.

"There may be a disposition to add some prorision bringing the corporation under the jurisdiction of Ohio. Tou must be careful that nothing of this kind is done in such general terms as to bring the stockholders under the operation of your Constitution or laws as to personal liability.

"I would like to have you revise this bill and put it in motion. We must rely on you and Judge Thompson to have it passed. It would be prudent to urge it forward as fast as possible.

"I enclose some passages cut from my points in a recent case, which touch on the questions I have alluded to.

"It is very desirable that Mr. Stansbery's bill, converted into a general form, or some other bill applicable to all railroad corporations in your State needing reconstruction, shonld pass. I trust you and Thumman will aid in effecting such a result. There are plenty more of cases needing your doctoring. I regret that I must write in so much haste. I have to leave here in lialf an hour, having just returned from Phil.

"MLr. Ogden is to-day in Pittsburg with authority to have a settlement effected if it can be.

"Do me the favor to let me have your views as soon as possible. Truly,

"S. J. Tilden."

\section{S. J. TILDEN TO M. VAN BUREN-UNFINISIIED}

"New Yonk, Feb. 21st, 1860.

"Mr dEAr Sir,-My mind has often turned to your letter, which I am some six weeks in arrears in answering. But I have in that time been three times called to Philadelphia, and once to Lebanon by the extreme illness of my mother and sister; and, altogether, have had my hands full. I am much obliged by the kind expressions of your letter, as well as the friendly interest you have taken in me.

"In respect to the subject which you incidentally mentioned in your letter, I do not think that my private business affords the elements of a desirable combination between John V. B. and myself.* It furnishes few occasions which

* This is no doubt the subject referred to in Mr. Van Buren's letter of October 14, 1859, in which his feelings were deeply interested. 
wonld give seope to his powers, less, perhaps, than ought to be arailed of even by nine; but it and other cares occupy me too much to leare any room for the ambition of eollecting the materials, or constructing a business of a different character. I content myself each day with what my hands find to lo. I have not been very fortunate in deputizing such business as $\mathrm{I}$ have generally had. It may be because the things which come to me are usually complex and diffienlt, or because I am exacting as to the mode in which my clieuts are served."

It is to be regretted that Mrr. Tilden's letter to ex-President Van Buren, assigning his reasons for declining to enter into a partnership with his son John, is incomplete. A more impracticable union for business purposes than such a partnership would have yielded can hardly be conceived. It is proballe that the original of this letter to Mr. Tilden may be found among the eollected papers of Mr. Van Buren, which have recently been presented to the Library of Congress, unless it was destroyed immediately upon its receipt, whieh is not unlikely.

\section{TILDEN TO JOIN CLANCY}

$$
\text { “N. Y., May 19, '60, Evenina. }
$$

"Mr denr Srr,-Your letter inviting' me to act as a vicepresident of a meeting to be held at the Cooper Inst. was recd. yesterday, but I was so busy in a trial that I had no chance to answer it earlier.

"Having elected a delegation in which we have confidence, it is contrary to my personal disposition towards them, as well as to my notions of what is most conducive to their power and usefulness in their conference with the other representatives of the Demoeracy of the Union, to interfere by any public meeting before they shall have completed their trust. Without questioning the judgment of those who think differently, I nust decline your invitation. "Very respectfully,

"Hon. John Clancy. "Your friend, S. J. TII.DEN." 


\section{LETTERS AND MEMORIALS OF SAMUEL J. TILDEN}

\section{S. J. TILDEN TO THE EDITORS OF THE "EVENING POST"}

" 2 Union Place. Tuesday Evevg. " Ocт. 9th, 1860.

"To the Editors of the 'Evening Post":

"Gentlemen,-You politely offer to publish in your columns a speech of mine which you seem to think was not adequately developed at the Cooper Institute last erening, and you add that my friends among your readers "would be glad to know how' I ' have reasoned' myself into the associations in which I stand on the Presidential question.

"If I had a speech already written I would at onee avail myself of the opportunity of submitting my views on public affairs to a mass of readers, among which are many cultivated intellects and some friends of my earlier years who, I respectfully say I think, are widely and dangerously wrong in their present political action. I have but the intervals of exhausting daily engagements in which to prepare a speech; but if after this explanation your offer shall continue open, I will endeavor within the next few days to write out in a condensed form what I think ought to be said, not to my friends only, but to all our citizens touching the present state of the country. If, indeed, it can be justly said that I have helped to lead the Evening Post into any ' heresies,' I acknowledge the sacred duty of showing it a 'decent way out' of them.

" With much consideration, I remain,

$$
\text { "S. J. Tilden." }
$$

"Though we invited Mr. Tilden to give us the speech which he proposed to address to his spectators-they wonld not permit him to call them his audience - at the Cooper Institute, we are quite willing to extend the courtesy to anything he may choose to offer us in which he thinks the public has an interest. The readers of the Evening Post know much better than the crowd he tried to address at the Cooper Institute that $\mathrm{Mr}$. Tilden never writes or speaks withont haring something to say worth hearing, though they have not lately been unfortunate enough to agree with him on Federal politics."

The foregoing letter, with the editorial comment which follows it, appeared in the Evening Post October 10, 1860. 
'The occasion which provoked it was the following account, which appeared a day or two previons in the Evening Post, of a meeting at the Cooper Union of maleontents, having little in common to unite them but their hostility to the party which had nominated $A$ braham Lincoln for President. They were mostly the maceounter-for débris of the old Whig party, who tried to disguise themselves by taking the name of "Merehants of New York." Mr. Tilden was invited to speak, but this motley audienee did not care to listen long to so prominent a political partisan of Jackson and Van Buren, who had also been the most formidable critic of all Whig measures during all their suecessive administrations:

\section{"THE TREMENDOUS DEMONSTRATION}

"The 'Dry-Goods party', as by general consent the fusionists have come to be designated, held what they ealled a 'Union meeting' last night at the Cooper Institute. They did not meet at Tammany Mall, for obvious reasons, though it must have made some of the gentlemen who contributed towards the expense of the entertainment feel a little queer when they found themselves associating politically with a class of men who eonld not be persuaded to put a foot inside of the old Wigwan. It has been observed that political parties, as they decline in strength, lengthen the list of ofticers supposed to officiate at their public gatherings, just as the shadows of mountains lengthen as the sun goes down. The Dry-Goods party did not attempt to be an exception; on the contrary, they seem to have made all of their party vice-presidents that they did not make president and secretaries. In looking over the list of gentlemen who figure on this oceasion, we could not but be struck with what Clay ealled the 'mutability of all human opinion.' It seemed as if the milky portion of the old barnbming party of ' $4 \mathrm{~s}$ which had somred from the effects of Republican thmoder, had been specially served up for the public entertainment. There was Dix, who ran for Governor with Van Buren in 1848 against Cass, nominated for chairman by Wilson G. Hunt, largely in the dry-goods line, who supported Van Buren and free soil as zealously and liberally as he now supports Breckinridge, Douglas, Bell, Sam \& Co. 
"Our old friend 'Tilden, who stood at the wheel during all those troublous times; who was one of the counsel for the Barmburners in the Baltimore eonvention of 1848, and who helped to lead the Evening Post into all its free-soil heresies without ever showing it any deeent way out of them, offered the resolutions and made a short speech. It would have been longer, but the audience wished to hear IVood. Either Wood or a song they must have, and so Mr. Tilden retired with his speech just as good as new, and, as it appeared, too good for his audience, that they might hear a song from a $\mathrm{Mr}$. Cosgrove, Wood being returned by the offieer ' not found.' 'The preference for Wood is explained, perhaps, by the faet that the first vice-president, W. B. Astor, was one of the ten or dozen gentlemen who certified to Mayor Wood's character when a eandidate a second time for the 'mayorality' - as Mr. Wood is in the habit of spelling the dignity he at present enjoys-and who recommended him warmly to the suffrages of the people. All the rest of the gentlemen who signed that 'eliaracter,' Moses Taylor, M. Aspinwall, the Browns, ete., figure also among the vice-presidents, and it is not strange, thercfore, that a meeting thus officered should prefer a speeeh from Fernando Wood to a speech from Samuel J. Tilden.

"Then there was Henry Grinnell, who paid liberally towards raising the standard of rebellion at the park meeting, held shortly after the nomination of Cass, in 1848, and whose name was freely used by the Barnburners until about the time that the Union-saving steamship companies began to be incorporated and subsidized by Congress. Since then he has had little or no interest in anything North, this side of the Aretic circle.

"John Coehrane, Dan Norris, Henry Eveson, William F. Havemeycr, Stephen Cambreleng, Charles A. Secor, Myndert Van Schaick, whom, to his great disappointment, the Barnburners failed to elect Mayor of the eity before the days of fusion, T. B. Tappen, John Van Buren, A. B. Conger, Addison Gardiner, ete., etc., make up the list of distinguished Barnburners of the milky sort who have 'turned,' and now form the eheesy pillars and arehitrave of the Dry-Goods party.

"The speakers for the evening were James IV. Gerard and Charles O'Conor, two of our ablest lawyers, skilled to make the worse appear the hetter reason, and, from long 134 
professional training, abont as much at home on one side of a question as another. As neither of these gentlemen were in good standing with the old Demoeratic party, the first being an old Whig and the other a fractions and crockerybreaking independent, they were listened to with patience by an assembly conspicuously impatient of anything savoring of old-fashioned Democracy.

"What effeet the bringing together such a crowd of officer's for such a thin display of speakers will have upon the dry-goods market will doubtless appear in the column where such reports are usually chronicled; what effect it will have on the Pennsylvania election will appear by the returns in to-morrow's Evening Post; what effect it will have upon the vote of this State is of no sort of eonsequence, for we were sure of a large majority before it was held, and of course we may reasonably expect a larger majority now.

"We are sorry about Mr. Tilden's spech. We have no doubt it was a good one, and as we are the friends of free speech we will publish it eheerfully in the Evoning Post if he will give us the opportunity. It will reach a great many more of his friends through our colmmns than stood within the reach of his voice, and they will all be glad to know by what process so elever a man has reasoned himself into such bad company."

\section{WM. CASSIDY TO TILDEN}

“ 'Atlas \& Argus' Office. "Albaxy, Octr., 1860.

"Dear Tilden,-Newell tells me that you are preparing a reply to the Post's appeal to be 'shown the way out.' Do so; and it will give me a chance to write an editorial, which I intended and postponed till the oceasion passed by. I enclose a reply to an assault upon our consisteney, the last half of which is apropos to the Post's inquiry. I am afraid your eommittee of fifteen will do more harm than goodas usual. You recollect how the Castle Garden movement defeated Seymour and elected Chureh, reversing its intended effect, and how the Fifth Aveme movement of last year paralyzed us? Let it go, howerer, with the other blunders.

"What I write to you abont is to say that I intend to come down to New York on the 7 th proxo. and eonsult you 
in regard to a project which $\mathrm{O}-$ and I have long discussed - establishing a New York daily. Wre can readily get $\$ 60,000$ (or more) for shares, and from a few men. I can name Plumb, Dellolf, Johnson (of Oswego), Ross - besides Richmond, Cagger, Corning, Kielly, etc. We could add what an establishment here is worth, $\$ 40,000$ or $\$ 50,000$. The sum could be increased, and all subseribed ontside of New York. It is not for help (to ask you 'to go round with a paper,' as your party friends generally do), but simply for advice. Wesley, the banker, once proposed to sell me some of his interest in the Times if I would go in there. This is entre nous, and I allude to it only to explain why I am going to consult him, as well as you.

"If we could buy the World, the Express, or the Post, that would make the best beginning. If we established the New York Argus or The Age we conld start with a larger subseription and in better organization than any two other persons. Of course we would have to go to great expense, cmploy many hands and heads, and meet a fearful competition. But neither of us are without experience, and we have regarded the question on all sides. There must be, and there will be, a Democratic organ in New York. Who is to control it? In the transitive state of polities, 'that is the question.' There's a vast volume of Democratic patronage going to waste in the city, and still more beyond it. We send out 40,000 weekly papers from Albany, and in less than a year could raise it to 200,000 if we were in New York. That is as much as Greeley has for his Tribune, and that is the source of its influence.

"There is plenty of ability in New York that could be called in. What is wanted is conduct-a policy, prudence, independence-for the political part. For the business part we want competent men-an association, if possible, with a great publishing house, in order to avail ourselves of literary talent, not allowing it, however, to be our publisher. Commercial and other reporters, and enough literary talent to supply a daily feuilleton; for we must call on the aid of fiction, as the Paris papers do, and so gratify a taste which is stronger here than anywhere else. I would commence by getting Hawthorne or some writer of equal talent to furnish a novel, which might be republished afterwards in a volume, and which would thus pay. To do this, we should want a paper like the World. We will reverse the wish of Arehi- 
medes: give us the World, and we will find the lever to move it.

"But I intend to ask your advice, not to forestall it. Until I see you, which will be after the November triumph, I remain

$$
\begin{aligned}
& \text { "Yr. frd. \& fellow-sufferer", } \\
& \text { "War. Cassidy. }
\end{aligned}
$$

"When Wood was elected by Greeley's agency, I made up my mind that he would administer retributive justice upon G. \& Co. ly some stupendous organization of the canvassers. But you have an honest vote of 100,000 . The Republicans are not entitled to more than 30,000 of this. Give us 40,000, and we will carry the State. Organizemake them do it. The registry will facilitate such work."

JOHN BIGELOW TO S. J. TII.DEN

"OCtober 10, 1860.

"Dear Thlden,-Send on your MS. to-night if you ean; that is, what is ready, and the rest as early as possible tomorrow. I will then announce it to-morrow for Saturday. - If we undertake to get it up to-morrow it will not be well printed, as all ontside matter must be in hand before 10 o'clock. Of course, therefore, the men will have to work on it in the afternoon after the work of to-morrow's paper or to-day's to get it up and properly proved. Besilles, I want time myself to read it, for I presume, if you sleep in my bed, I should have the privilege of making it up.*

$$
\begin{gathered}
\text { "Yours truly, } \\
\text { "Joirn Biaelow." }
\end{gathered}
$$

\section{JOHN IBIGELOW TO S. J. TILDEN}

$$
\text { "Eva. Post, Oct. 11, } 1860 .
$$

"MY Desr Trumen,-Py the Post of to-day you will see that our printers are waiting for eopy. I desired to put you in a position to be regarded by the public as a representative of your party, and by your party as their chief and most capable champion and defender. If you prefer to put what you have to say in the form of a letter you need not hesitate

* For further particulars of this memorable and very able letter, see Life of Tilden, Harper \& Brothers, 1895. 
to do so in consequence of anything which has passed. Artistically, I can imagine that the letter shape will have some advantages over an molelivered speech, and I would recommend it, though it was my purpose only to say I hoped you would unburden yourself in just the way you find most agreeable.

"If you can let me know, a day or two in advance, when your copy will be ready I shall be more sure to secure a place for it without delay.

"Speaking in your interest, not in our own, I would advise you to be as brief as possible, for I want to have what you write read. If you can get within a couple of columns, so much the better for all concerned.

"Let me suggest that whatever you have to say you will lose nothing by conceding the error's which have brought the Dem. party to its present condition. It becomes you to write as a statesman, and not as a partisan, in this instance, at least, and perhaps we Republicans, as well as those you particularly address, may profit by your teachings.

"Yours truly, "JoHn Bigelow."

\section{S. J. TILDEN TO JOHN BIGELOW}

"2 Unjon Place, Oct. 11, 1860. "Ev.

"Mr dear Bigelow,-I thank you for the very kind terms of your note. I entirely agree with you as to the letter form, and the space you suggest is what had occurred to me as proper. I shall keep as nearly as possible to it. I note what you say as to notice. My only real diffienlty is the rush of things in which I live.

$$
\begin{aligned}
& \text { "Very truly yours, } \\
& \text { "S. J. TildDen." }
\end{aligned}
$$

\section{S. J. TILDEN TO JOHN BIGELOW}

"OCT. 27, 1860.

"My dear Bigelow,-I extremely regret that my letter" has reached such unexpected length; and I have condensed it as much as possible, and omitted much which I desired to say, but you did not propose, nor I undertake, to have the thing done too imperfectly. I must, therefore, throw 
myself upon your indulgence. I assume you will, and that the balance will appear on Monday.

$$
\text { "Very truly yours, }
$$

"Sat. Morn., Oct. 27, 1860.

S. J. Tildins."

\section{EDWARD EVERET'T TO S. J. TILDEN}

"Nov. 6, 1860.

"MY Drar SIR,-I camnot content myself with a mere formal acknowledgment of your admirable pamphlet, which I have read with extreme pleasure. Nothing which I have met with on the dreadful subject which now convulses the comitry has seemed to me more elearly or forcibly urged.

"I remain, dear sir, with high respect, "Very truly yours, "Edward Everett."

SENATOR J. M. MASON* TO S. J. TILDEN

"Selma, Near Winchester, Va., $12 t h$ Novr., 1860.

"Dran Sir,-I have just read your pamphlet-"The Union, its dangers, and how they can be averted.' 'To say only that it is the best which the oceasion has ealled forth, would be to do as little justice to my discrimination as to its merit.

"It is too late now to arrest the catastrophe which it shows impending; but it must, to minds capable of understanding fact and logic, force the people to pause and consider.

"I trust that measures will be taken to give it an extended circulation in the Northern States; in the South its effect only ean be to make the people eomprehend what they already feel.

"My note, however (which I am obliged to write through an amanucnsis), is only to thank you for this great contribution to American thought, and, like the hmory schoolboy, to ask for more. Can you oblige me by sending me some twenty eopies, or as many as you can eonveniently spare?

"From your obliged

"friend and servant,

"S. J. Tilden, Esq., New York.”

"J. M. Mason.

* The following year Commissioner of the Confederate States to London. 


\section{G. S. HILLARD TO S. J. TILDEN}

"Boston, Nov. 19, 1860.

"DEAr Sir,-I beg leave to acknowledge the receipt of, and to thank you for, your letter on the Union. I agree with you heartily in your views: they are sound, wise, and patriotic; but what avails it to proelaim them? Anybody who preaches moderation and forbearance - who endeavors to calm the tempest of exeited feeling-is ealled ' a skulking neutral,' or, at best, an obsolete old fogy, whose proper place is in Noah's ark. We must learn wisdom by the smart of folly, and it looks very much as if the teaching was begum. I look upon Mr. Seward as the most mischievous man now in the public service; and for his incendiary course he has not the apology of a fervid temperament and rash blood. $\mathrm{His}$ words are the more dangerous, because so deliberately uttered. But I rejoice that you have written the letter, and that so many patriotic and judicious men have been willing to speak and write as you have done. Always anticipating the election of Lincoln, I have been in the habit of saying to our friends that the value and importance of the Union party would not be fully apparent until after that event. I think I was a true prophet. If the comntry is to be safely navigated through the shoals which are around and ahead, it will be by the agency and instrumentality of the Union party.

"Samuel J. Tilden, Esq."

"Yrs. truly, "G. S. Hillard.

THE PROMISED REPLy OF THE "EVENING POST" TO THE

LETTER OF SAMUEL, J. TILDEN

\section{(Continued and Concluded.)}

"The people of the United States voted yesterday upon the questions at issue between the Republicans and their adversaries, as represented by Lineoln and Hamlin, eandidates of the former, and by Douglas and Johnson, Breckinridge and Lane, and Bell and Everett, representing the latter, with the following result:" 
LIXCOLN AND HAMLIN.

Commecticut ...........

Illinois .............. 11

Indianı $\ldots \ldots \ldots \ldots \ldots \ldots \ldots$

low: $\ldots \ldots \ldots \ldots \ldots \ldots \ldots \ldots$

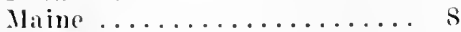

Massitchusetts .......... l:3

Michigan .............

Minnesota .............. 4

New llampsine.......... 5

New York.............. 35

Ohio ............... 23

Pennsylvania .......... 27

Rhode Island............. 4

Vermont ............. 5

Wisconsin $\ldots \ldots \ldots \ldots \ldots \ldots$

Total

169

WOUGLAS AND JOHNSON.

Missomi .............

Total.............

DOUBTFUL.

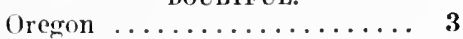

California $\ldots \ldots \ldots \ldots \ldots \ldots$

Total............. 7

\section{RECAPITULATION.}

for Lincoln and Hamlin........................169

For Breckintidge and Lane.....................61

For bell and Everett......................... 57

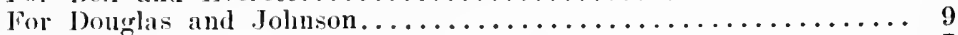

For Doubtful $\ldots \ldots \ldots \ldots \ldots \ldots \ldots \ldots \ldots \ldots \ldots \ldots \ldots \ldots \ldots \ldots$

Whole electoral vote.......................

Lincoln's majority over all, certain ................ 35 If Oregron and California vote for Lincoln it will add to his majority 7

Total

42

TILDEN TO W. II. SWATNE ON TIIE P'ROCURING A CILARTER FROM THE STATE OF OHIO FOR THE PITTSBURG, FORT IVYNE \& CIIIC.IGO RAILROAD

" Dec. 6,1860 .

"Mr pear Sir,-Two modes of investing the future owners of the P. F. W. H. R.* with a corporate character within the State of Ohio have been suggested.

" 1 . One is to make them a corporation of the State of * The Pittsburg, Fort Wayne \& Chicago Railroad. 
Ohio-by ereating them a new corporation, or by continuing to them the old eorporate franchise.

"I nuderstand Mr. Stanbery and Mr. Hunter to propose the latter method. By providing for the transfer of the existing franchise to be a corporation by a general law, they avoid the constitutional provision that 'the general assembly shall pass no special act conferring corporate powers.' They think, also, that by preserving the identity of the existing franchise they ean avoid the operation of the constitutional provision "that in all cases each stockholder shall be liable orer and above the stock by him or her owned, and any amount mpaid thereon, to a further sum, at least equal in amount to such stock,' npon the ground that the provision is not retractive, and was established subsequently to existence of this corporation. They think, also, that although the identity of the corporation will be preserved, it can be discharged from liability for the debts and contracts which it has made. If it should be found to be liable for those debts and contracts, the main object of the reorganization would fail.

"2. The other mode is to make the future owners a corporation of Pennsylvania or Illinois, and to enable that corporation to hold, maintain, and operate the part of the road which is situate in Ohio, without being a corporation of the State of Ohio.

"To enable a Pennsylvania corporation, for instance, to hold, maintain, and operate the part of the road situate in Ohio two things are necessary:

"First, that it should be endowed by the law of its ereation (which would be the act of Pennsylvania creating it), with eapacity to hold, maintain, and operate the part of the said road which is situate within Ohio.

"Secondly, that it should have the consent, implied or expressed, of the State of Ohio to the exercise within that State of its powers to hold, maintain, and operate the part of the railroad situate within that State.

"Such consent in this case will be implied, unless the implication is negatived by express legislative declaration of the public policy of the State.

"As the laws of Ohio allow an individual purchaser to hold, maintain, and operate the railroad-which individual might be a non-resident-and as there is no policy established by legislation or by a judicial construction to disable 
a corporation of another State having the requisite capacity from doing so, the case comes clearly within the principle on which nearly all the acts of corporations in other States than those of their ereation are sustained by the courts as lawful.

"The rights of the State of Ohio are not violated; for it is by her eonsent that these powers will be exereised within her dominion. 'That consent could have been withheld. I do not say that it might not be withdrawn by legislation, not so as to divest rights of property which acerued while it existed, lout so as to produce inconvenient eonsequences to the tenure of the corporators : nor will I advert to the fact that a vast number of transactions are daily earried on in some of the States by corporations of other States, subject to the same possibility, or that in some States, as in New York, most corporations exist subject to full legislative power to repeal the act conferring the franchise.

"For I have not doubted-I have uniformly expressed the opinion that in a case of the peculiar nature and vast importance of the present it is wise to obtain an express consent.

"Shall that consent be given by special act or general law? Would it have any effect on the extent of the liability of the corporations?

"The essence of the corporate character is that several individuals are mited in one body-enabled to exist and act as an artificial person created by law, the members of which ean change without impairing the identity of that body of person.

"The corle of regulations, according to which it exists and acts, which fix its modus is ineidental to that creation.

"Its other powers, which may be and often are possessed and exercised by natural persons, are not, strictly speaking, corporate powers, such, for instance, as making discounts, granting insurances, operating railroads; there is nothing in the nature of these powers which neessarily eonfines them to corporations. 'They are not of the essence or of the ineidents of the corporate character. I think the prohibition of the Ohio Constitution that "the general assembly shall pass no special act conferring corporate powers' is a mere paraphrase of the prolibition of the New York Constitution, contained in the following provision: Corporations may be formed under general laws, but shall not be created by 
special act, ete. The next clause of the Ohio Constitution provides that 'corporations' may be formed under general laws.

"The provision was, in the main, copied from the Constitution of New York. The modification of details accounts for the change in the collocation.

"In a cursory review of the discussions in the Ohio convention I see no trace that anything further was intended by the prohibition than to interdict the creation of corporations by special acts.

"That construction accords with the true meaning of the yords 'corporate powers,' which is powers essential or incident to the nature of the artificial being created by law - such as the power to take a common name, to have corporate succession, to contract and be contracted with, and to sue and be sued as one person, etc. These are properly corporate powers. It is true the words are sometimes nsed to include all the powers which the particular corporation possesses; but that is a loose and inaccurate use.

"I think that the correct interpretation of the publication is that it simply forbids the creation of a corporation by a special act of incorporation-nothing more. It does not forbid an act operating to enlarge, modify, or restrict the rights of an existing corporation, any more than it does a similar act in respect to a natural person in a like case. Still less does it forbid such legislation in respect to a foreign corporation. It is enough for the present case to say that the clause does not prohibit a legislative recognition or an express sanction of an existing comity of the State in favor of an existing corporation of another State.

" 1 . I am, therefore, of opinion that a special act declaring the assent of the State of Ohio to the exercise within that State of all the powers necessary for a beneficial use of the Pittsburg, F. W. \& Chicago Railroad by a corporation of Pennsylvania or Illinois, which should have become the owner of the part of such railroad situate within the State of Ohio, would be valid and effectual.

"A general law would, of course, be somewhat preferable, as it would avoid this question. If it is certainly attainable, I would seek our legislation in that form.

"But I foresee the possibility that it might excite more jealousy than a special act, because its full application and 
use cannot be certainly anticipated. I foresee, also, the possibility that it may affect special cases of existing interest, prejudice, or passion, of which I am ignolant.

"In the first section of a draft of a general law which I have hastily made at a suggestion, I have tried to avoid the first of these two objections by limiting the cases to which the law applies.

"1. An existing railroad. State.

"2. Partly situate in Ohio and partly in some adjacent

"3. Sold under an existing lien.

"4. Aepuired by a corporation of another State in which another" part of the same railroad is situate.

"5. Such corporation acquiring the part of the railroad situate in that other State.

" 6 . Of course, such corporation having the capacity to take and operate the part situate in Ohio.

"Perhaps I may have put in more limitations than are necessary.

"Whether the measure will run foul of any other interest can be better judged of by men conversant with the state of affairs in Ohio and in its legislation.

"The general law, as proposed, is not more liberal than the existing consolidation act of Ohio. We ought to be able to obtain it. If there is a strong probability that we camnot, we ought to obtain a special act of a sinilar nature, applicable only to our particular railroad.

"2. The advantage of not making the corporation a creation of the State of Ohio is that it certainly and unquestionably aroids this clouble liability of the corporators imposed by the Constitution of that State.

"The degree of liability to which the individual corporators shall be subject is a part of the code of regulations specifying the mode and conditions of the existence and action of the artificial being. Sometimes it is nothing beyond the stock paid in. Sometimes, as by the Ohio Constitution, it is a limited amonnt beyond the stock paid in ; sometimes it is absolute, as in the ease of partmers. It is not of the essenec of eorporations-it is a regulation imposed by the sovereign who ereates the artificial being an incident to the particular corporation. Nolody but that creator condel impose such a regulation. The most any other State could do would be to refuse its comity to a corporation until it 
should get the regulation imposed by the lawful authority of the State of its creation.

"Bcsides, the provisions of the Constitution of Ohio applies only to corporations created by or under the laws of that State. It does not purport to operate on corporations of other States transacting business in Ohio under the comity of its sovereign.

" 3 . In respect to the general act proposed by Mr. Stanbery and Mr. Hunter, I think they should prepare it and that we should co-operate in procuring its passage. It would be open to our choice if on consultation we shonld prefer to act under it; and it would be useful in other cases. My illea originally was to have that general law and a special act for the Pittsburg, F. W., C. R. R. If we change the latter to a general law, it makes two of that character; but I do not see any objection if we can get them both passed.

"I should like to have a copy of the draft of such an act as Mr. Stanbery and Mr. Hunter propose.

"The draft of a general act which I send contains provisions which onght to be considered as consulted upon. I have prepared them without, perhaps, sufficient study of your laws on the subject, and without knowing the temper of your Legislature.

"In some particulars they must be regarded as mere suggestions. Consider-

"1. The clause of Sec. 1, subjecting the company in respect to its management of the part of the railroad to the duties and regulations imposed by your general lawswhether there is any provision which should be accepted, whether this clause ought to be made more stringent in order to be satisfactory to your Legislature. But care should be taken not to use expressions which could include the personal liability provisions of the Ohio Constitution and laws.

"2. The clause of the same section subjects it to be-

"Section 2 is intended to give the same power as to mortgaging the rolling stock, etc., which is contained in the Pennsylvania act. I do not think this ought to be objected to.

"Scetion 3 is an adaptation of a clause proposed last summer.

"I cannot send a fair copy of the special act without 
losing a mail. The general one is sufficient as a basis of consideration and consultation.

"I would like to have you consider the matter, and must contrive sone way to meet in consultation.

"I address this letter to you, though its contents are for Mr. Stanbery, Mr. Hunter, and Judge Sherman, to whom I pray you to offer my best respects. "Yours truly,

“ W. H. Swayne, Esq., "S. J. Tilden.

"Vew York, Dec. 6, 1860."

TILDEN TO W. B. OGDEN

"Neiw York, Dec. 1\%, 1860.

"Mr dear Sir,-As you leave in the morning to return to Chicago, I seize a few moments this evening to submit to you some suggestions as to the present crisis in the affairs of our country. I know you have no personal aspirations; that you are exempt from the blinding and misleading influence of active partisanship; that your disposition is equitable; that you have no motive but the public good-no interest except in common with all patriotic citizens; and that, far better than most men, you understand that there is usually another side to a controversy than 'our side.'

"Your situation may enable you to be of great service to your country and to mankind, and of not less service to a gentleman who to-day oceupies a more important and responsible position than has been the fortme of any other of his generation. Of course $\mathrm{I}$ allude to Mr. Lincoln. His patriotism I do not doubt. 'The impression lie made on me, upon two occasions when I casually met him, was that of a frank, genial, warm-hearted man. In the actual duties of the Presidency he cannot but take conservative views. No man can have a motive so strong and yet so noble to prevent his own name from closing, amid public sorrow and shame, the illustrious roll of Ameriean Presidents which began with Washington.

"It must be his renown or his calamity to decide whether he shall be the Chief Magistrate of a whole country or of half a country. Providence has cast upon him that immense responsibility. In saying this I do not touch the question, What has cansed the misehief? I speak only as to the question, Who has the pouer to save the country? 
" 1 . The reality of the danger of disunion, I think, cannot be doubted. The cotton States are far more manimous for secession than our fathers were when they made our revolution despite of the royalist majority. Practically, their people are unanimous. We ean only hope for an effective minority forming itself in some qualified position within the current of popular opinion. A statesmanlike policy would be to aid the formation of that minority- to strengthen it that it may become a majority, to create, to hasten, to swell the reaction for which we hope.

" 2. Our first necessity is to comprehend the crisis. That is difficult. A man on one side of a question cannot easily turn out the set of ideas which fill his mind and admit the opposite set, even for an experiment. Nothing is so difficult in ordinary experience as to see both sides of a question. For us who have been educated with Northern ideas or in party controversies, we must be almost more than mortal to be able to take a perfectly candid and impartial view of the position of our adversaries. It is necessary to do moreto imagine ourselves in their position, in order to form a policy adapted to their case."

\section{TOWNSEND WARD TO TILDEN}

“Philadelphia, Dee. 19, 1860.

"Dear Sir,-Last evening, at Mrs. Gilpin's, I met Mr. Ogden, who kindly gave me a eopy of your letter to Mr. Kent.* It is so well calculated to do good that I want to obtain copies for distribution. Can you have your publisher send me fifty, with a line stating the eost, which I will remit? Years, perhaps, of the dreary labor of reconstruction of our empire are before us, and it will not do for us who foresaw the storm to desert the wreck while a single plank of hope remains.

"I send you a copy of a pamphlet by a Mr. John R. White, of this city. It has some good points.

$$
\begin{aligned}
& \text { "Very Respectfully, } \\
& \text { "Townsend WARD, }
\end{aligned}
$$

"204 S. 5th St.

\section{"Samuel J. Tilden, Esq."}

* The letter here referred to will be found in the Writings and Specches of Samuel J. Tilden. Harper \& Brothers, 1885. 
"New Yors, DCc. 1860.

"MY dear Sir,--Inmediately on receiving your note I eansed 50 copies of my letter to Judge lient to be sent to your address. I adknowledge a deep sense of the favorable estimate you express of that effort, on a sulden occasion, amid the toils which fell upon me as one of the Union committee, to recall our Northern people to the duty of justice and fratemity towards our Sonthern fellow-eomntrymen. I lave delayed writing to you to say so until I conld seize a moment in which to add a suggestion as to the future; and, in the mean time, how rapidly, how fearfully, have events been hurrying forward!

"It seems, too, that these events cast largely upon the Virginia statesmen of this generation the momentous duty of saving from destruction a political system which we and the world owe mainly to the Virginia statesmen of the golden era of the Republic."

\section{S. L. M. BARLOW TO TILDEN}

"Private.

"New York, Wednesday.

"Mr dear Tilden,-T understand that you are to be consulted this erg. as to the propriety of assuming control of the Pres't and his adm'n from this time forward on his promise to surmender everything to the Demoerats. This plan assmmes that Church and yourself will enter heartily into this movement, and that one of you will go into the Calinet.

"Whoever does so will, in my judgment, ruu a very serious risk of danaging his own record; the adoption of the plan will hasten rather than retard impeachment; it is not unlikely that the finanees may be deranged, which will be chargesible to ns, and with Jolnson's sins of omission and commission on onr backs, we stand a fair chance of defeat, when otherwise we might win in the coming Presiclential fight. I see nothing to be calined except a few places, very few, too, with Comeress against us, for a few men who want position. I hope, if you agree with me, you will not countenanee the plan in any fom.

S. J. Tilden, Esq. " Y'rs, S. L. M. Bariow." 


\title{
LETTERS AND MEMORIALS OF SAMUEI, J. TIIDEN
}

\author{
$1861-1567$ \\ TILDEN TO WYNDHAAI ROBERTSON \\ “ New York, Jan. 13, '61.
}

"Mr DEAr Sir, - I read your letter, and the printed one you were kind enough to send me, with much pleasure, and are them to Mr. Miller, with the stipulation that they should go to Messrs. Hewitt and Cooper in succession. In the main I assent to your views.

"I have no doubt-

"1. That the late olection" was not a verdict of the Northern States on the theoretic questions urged by the Republicans. Masses went for Lincoln, from habit and association, as a lineal succession from Whiggism. Masses from mere opposition to the Democratic party, and from all the causes which gradually operate to make a revolution between the ins and the outs. The drift created by the disorganization of the Democratic party, and our inability to present any single candidate as a point of union to the conservative sentiment, and the concession from April till October that we must inevitably be beaten; I say this drift alone might fairly be 24,000 out of 675,000 voters, or $31 / 2$ per cent., which would have changed the result in N. Y. and in the Union.

" 2. That a very important reaction has already taken place.

"3. That, even if we had not had our present difficulties to bring men to consider, Lincoln's administration must necessarily go utterly to pieces when it came either to present affirmative measures or to distribute the patronage.

" 4th. That, on the whole, through all these struggles and much apparent increase of the anti-slavery element, there is growing a larger and stronger party, eapable of doing the Southern States full justice, than ever has existed for half a century past; I mean, capable of recognizing, on reason and principle, the right and the necessity the Southern States have to grow in the natural expansion of their industrial and social systems. In 1820 the North was unanimous in claiming the right to attack conditions operating after a State should be admitted. That idea is now

* Mr. Lincoln was elected President on the 7 th Nov., 1860. 
abandoned by a vast majority of our people. It is natural that when a new question arises, assumed to be within our constitutional jurisdiction, our people should all start to apply to it the ideas on which they have acted at home. To sec that it cannot be wisely disposed of by their merely voting in respect to it as if it were a purely domestic question; that they must ealeulate for the co-existence and expansion of the two systems; that they must partition the Territories-is a later stage in their political education.

"I am of opinion that prevalent errors have, in the main, run their course; and we need only to give our people a fair clannee to secure the adoption of a wiser and better system than they have ever before understandingly aceepted.

"If the present Congress continues unable to do anything adequate, I think the next best thing will be a convention of all the States to propose amendments to the Constitution, with an arrangement, if practicable, to keep the parties in stalu quo while those amendments are being perfected and submitted. The convention should be elected in distriets on the basis of the House of Rep. The submission should be to conventions.

"That would make two popular elections necessary. The conrention would be sure to be conservative. By summer the disintegration of the Republican party would be completed, the reaction perfected, and three-quarters of the States would ratify amendments substantially on the basis of Crittenden's propositions.

"Our people are temporarily misled, but by a vast majority conservative at the bottom. We only need time to bring them to a sound position.

"Excuse the haste with which I am compelled to write, and believe me,

$$
\begin{aligned}
& \text { "Very truly, } \\
& \text { " Your friend, } \\
& \text { " (sd.) S. J. Tilden. }
\end{aligned}
$$

"Hon. Wyndham Robertson, "Richmond, Va."

Dudley Burwell was a prominent lawyer in Albany, a thoughtful and estimable man, and had been an active Demoeratic partisan of Van Buren in opposition to General Cass in 1848. He shared Mr. Tilden's apprehensions of a eivil 
war as the inevitable result of Mr. Lincoln's election. IIe held no office himself, and I am not aware that he ever sought any. His letter is valuable as an illustration of the diversity of opinion among leading men of all parties by which M[r. Lincoln's govermment was perplexed during the three first years of his administration. Advice was in abundance, but no two counsellor's entirely agreed about what the government should do or abstain from doing. It was impossible to divine the opinions of the people upon any subject, the succession of new and unfamiliar events was so rapid and surprising.

\section{BURWELL TO CASSIDY}

"I pray you read this letter immediately!

$$
\text { “Jan'y 29th, } 1861 .
$$

"Mr dear Cassidy,-I received your telegraph this evening-and so kind a message would have started me at once for Albany, but one side of my face is badly swollen, and unless it is better to-morrow I must keep within doors.

"From the names of the delegates to the convention, and the disrelish now almost universally expressed against coercion, do not doubt its expression will be strongly against war.

"I hope they will make Gov'r Throop president, and that they will name Mr. Fillmore or Gov'r Hunt, Gov'r Seymour and Mr. Brady or O'Connor and Mr. Belmont to visit Washington and such other places as they shall think advisable for the purpose of persuading all belligerents to defer all hostile demonstrations for a period of 15 months, or until the 4th of July, 1862 , in order to give the people time to consider the whole subject and to act upon it in snch way as may be agreed upon.

"Time is necessary. It is indispensable. And if the convention will confine itself to that one point and ask time for consideration it cannot very decently be refused.

"Time is wanted-

"1st. That Mr. Lincoln may dispose of his patronage.

"2ud. Until elections ean be held in all the Northern States, in most of which the Republicans would be defeated. "3rd. That the South may try the Southern confederacy, 
in which they will probably fail to realize the golden advantages, and will be quite willing to resmme their places in the Union when they ean do so with honor.

"I think Legislatures may be elected next fall in $2 / 3$ of the States, a convention called, good amendurents proposed and ratified, so as to bring all the States again into the Union, and that fonr convention is the proper body to start this project at this time.

"If it takes this course it should appoint an executive or corresponding committee to act and correspond with other States, and shonld omit expressing any opinion as to the particular amendments now before Congress, so as to be free from all commitments to special and particular projects.

"I think this the only way of preventing war and saving the Union.

"I hope the resolutions will refrain from condemning the secelling States, also from demanding the forts to be reclaimed, and, in fact, everything that can lead to war.

"I had a talk yesterday with Mr. Loomis, and he understands ny views, and will, I belicve, act in accordance with them, as they seemed to be his also.

\section{"Wednesday Morning.}

"The two sides of my face are too mequal to show it in Albany, so I will add a few words which I think the most important I have ever penned, muless there shonld be some one or more who have by careful reflection come to the same conelusion; and I hope yon will not rejeet them on the first perusal, but weigh them, refleet upon them, suggest them to Richmond, I 'an Buren, O'Connor, ete.

"T'o direct the whole action of the convention to initiate a call of a national constitutional convention through a requisition upon Congress by the States, and demand the necessary and indispensable time to efject this object.

"Such aetion will drive the Republicans to abandon their warlike measnres, and will very likely hurry them either to the adoption of some of the measures before Congress or to take the initiative this winter for the eall of a national convention while they have the apparent power of controlling it.

"Such a movement would carry every Northern State exeept Massachusetts and Vermont, would restore the Democracy to power, and revive and invigorate the Union. 
Start it, I implore you, and do not let the convention exhaust itself on the rubbish now before Congress. We must strike a blow at the overwhelming patronage of the Federal government, and restore it to the States to augment their power. We must place the South in a position where it will feel its equality, and have the means of defending itself in its own hands.

"By taking this course, simple and pure, invigorating it with all the spirit and rehemence of the convention so as to arrest the attention of the whole country, you will open a door for the reunion of all Democrats at home and abroad, and save all that is worth saving in our institutions.

"You reeolleet Aet. 5-Cons. U. S.-that Congress shall, on the call of $2 / 3$ of the States, call a convention.

"You initiate this proceeding, then you have a reason for" demanding peace, for you have a constitutional remedy to propose. You have an object always ahead to accomplish, all old, obsolete issues are dead, and you have always hope to influence the masses and the Union to love to incite all men to its restoration to health and vigor.

"If this plan of action is proposed by others, encourage it if you have resolved upon it; be confirmed in your resolution, but do not, I beseech you, reject it because it eomes from so humble a souree as myself. I faney I hare bestowed as much ealm reflection upon all the phases of this state of the country as all the members of the convention. I believe no one can be personally less interested, whether we all go to chaos and confusion, or come out with renewed vigor from the dangers of this dark hour.

"If it shall appear that I am a suggester, then I beg you to place the matter in Van Buren's hands and let him at the first practicable moment lay the subject fairly and squarely before the convention. And as more think upon it they will admit it is the thing to kill the Republican party. If John is obdurate try Seymour and some one else.

"Wm. Cassidy, Esq. "Yours truly,

D. Burwell."

\section{BURWELL TO CASSIDY}

$$
\text { “Jan'y } 30 t h, 1861,11 \text { A.M. }
$$

"Mr dear Cassidy, - T have just put a letter in the postoffice explaining why I am here instead of being in the cars on my way to Albany, and now I acknowledge the receipt 
of yours of last evening. It would have been a most agrecable surprise to me had I seen you and Cagger on Saturday or any other day approaching my domicile through banks of snow. And I hope, as you have conceived the project, you will not abandon it but come at any time.

"The letter I post you this morning is of grave inport. as it opens a practical work for the convention to do, and will put you on the right road to save all that is savable of our present Union.

"Do not let the Democratic sink into an Opposition party, but present an attainable object-a work to be accomplished. One that does not bring into discussion any of the questions which have heretofore divided persons possessing the same principles.

"The only fear I have is that, if the convention shall prove unanimous in dentanding time until a convention of the States ean be called, it will drive Weed and Seward into the same measure, and they will endeavor, through their present legislators, to accomplish the same object; but this is balanced by the consideration that they must then preserve the peace.

"Another fear I have is about the forts p. p. Let this be left in the discretion of the committee you send Soutl. I think no harm could come from surrendering those posts to the States where they are located-during the stay of proceedings; of giving them, the seeeding States, the benefit of postal and other benefits on their stipulating to collect the same revemues as are collected in other ports of the United States, until it becomes apparent that the Union cannot be restored.

"In any event, I hope and pray that no harsh, unkind, or reproachful word will be used against the seceded States, and that they may see that there is a real, substantial body of men who can and do look at the matter in its true light. "Yours truly,

"D. Burwell."

\section{G. W. NEWELL TO TIIDEN}

“ Wasmington, D. C., froby. 6, 1861.

"Dear Tildex,-I got here Theshlay night. I camnot say I have got any new ideas, except that it is important for such Northern men to be here as can command the ears of our Southern friends-I mean of the border States, for the 
rest either have none at all or they are very long ones, and are attended by the other peculiarities of the animal whose head they adorn. The bordermen complain of the precipitancy of the South. They, themselves, take time to deliberate, in the presence of such weighty action, though the aggrieved party. How much more time do the people of the North need to determine what to do, dumbfounded, as they are, and slow to see preeisely where they are, and what they have done, and how far they may make reparation. It is about out of the question to expect anything from men elected on the Chicago platform, unless from the action of their constituents, in some way. Some bordermen I have seen admit this. Your letter has given you power to influence these men, and it is a moment when you should make a sacrifice to exert it, if a sacrifice is necessary. I think you should come at once.

"I found at Mr. Eames' last evening Mr. Everett, Crosswell, Guthrie, W. B. Lawrence, Col. Berrit, and Count Garowski.

“S. J. Tilden, Esqr., New York. Yours, \&c., "G. W. Neweld.*

"Mr. E. wishes me to be emphatic."

GENERAL WINFIELD SCOTT TO WM. H. SEWARD

"WASHington, March 3, 1861.

"Desr Sir,-Hoping that in a day or two the new President will have happily passed through all personal dangers and find himself installed an honored successor of the great Washington, with you as the chief of his Cabinet, I beg leave to repeat in writing what I have before said to you orally, this supplement to my printed 'views' (dated in October last) on the highly disordered condition of our (so late) happy and glorious Union.

"To meet the extraordinary exigencies of the times, it seems to me that I am guilty of no arrogance in limiting the President's field of selection to one of the four plans of procedure subjoined:

"1. Throw off the old and assume a new designationthe Union party. Adopt the conciliatory measures proposed by Mr. Crittenden or the peace convention-and my life

* A kind man and enjoying the confidence of Mr. Marcy who had been Secretary of War under President Pierce. 
upon it, we shall have no new ease of secession, but, on the contrary, an early return of many, if not of all, the States which have alrearly broken off from the Union. Without some equally benign measure the remaining slave-holding States will probably join the Montgomery Confederacy in less than sixty days, when this eity, being inchuded in a foreign country, would require a permanent garrison of at least 35,000 troops to protect the government within it.

"I stop here to call your attention to the fact that Maryland did not join the Montgomery Confederacy, and yet with Maryland on our side to-night, it requires a garrison of 150,000 men to protect Washington.

"2. Collect the duties on foreign goods ontside the ports of which this government has lost the command, or close such ports by act of Congress and blockade them.

"3. Conquer the seceded States by invading armies. No donbt this might be done in two or three years by a young and able general - a Wolfe, a Desaix, or a IIoche, with 300,000 disciplined men, estimating a third for garrisons, and the loss of a yet greater number by skirmishes, sieges, battles, and Southern fevers. The destruction of life and property on the other side would be frightful, however perfeet the moral discipline of the invaders.

"The conquest completed at that enormous waste of human life to the North and Northwest, with at least $\$ 250,000,000$ added thereto, and cui bono? Fifteen devastated provinees! not to be bronght into harmony with their conquerors, but to be held for generations, by heavy garrisons, at an expense quadruple the net duties or taxes which it would be possible to extort from them, followed by a protector or an emperor.

"4. Say to the seceded States, Wayward sister's, depart in peace! In haste, I remain, "Very truly yours, "Winfield Scott.

"Hoin. Wm. H. Seward, dec, \&c., \&e."

\section{J. L. O'SULIIVAN TO TIIADEN}

“Lisbon, May 6, 1861.

"MY DEAR Truben,-The heart-breaking news has just reached nis here, first of the attack and capture of Sumter,

* Mr. O'Sullivan had been appointed, by President Buehanan, Minister to Portugal. 
for which the signal was so madly and wickedly given by the administration (dominated, evidently, by the war portion of that party) in its despateh of reinforcements; and, secondly, of Lincoln's declaration of war by his proclamation for 75,000 volunteers for the reeapture of all the Southern forts, that is, for the invasion of the South-an act followed, of eourse, by secession of Virginia, and soon to be followed, I have no donbt, by that of all or nearly all the border States. Also the telegraph tells of a Massachusetts regiment resisted in an (insane) attempt to force a passage through Baltimore. Gracious God, that we should have lived to see such things! You can better judge, than I could describe, my affliction. At first it drew from me eonvulsions of tears. I think it is a greater grief than that I passed through a little short of a year ago. What doom is sufficient for the mad authors of all this! By that I mean, for $9 / 10$ of the erime, the ultra portion of the Republican party. The papers say that there is a common enthusiasm of all parties at the North for the support of the admn. I may stand alone, but I do not share this. I am extremely anxious to hear from you. Do write me your views. I chafe terribly under the impossibilities which alone prevent my hastening home. Not only have I not the means, but I eannot leave my debts here, when a short, prolonged stay will probably assure me the means of paying them. Then I shall come, to do my best in the fight at home for peaceful separation if reunion has beeome indeed impossible. What will New York do? I trust devoutly that if any troops mareh from our State southward they may consist only of Republicans. My hope now is that the North will at last realize the mad horror of the whole thing, and that a cloud of witnesses will arise to protest against its being earried further. Thus far the country has drifted along, both sides standing obstinate to the consisteney of their opposite theories. But surely all should now agree to pause and hold back! But the Republiean leaders, I fear, will now move heaven and hell to push and drag forward the North to sustain them in the position to which they have bronght things. And I fear much from the fighting character of our people. I dread the next news. If Maryland goes with Virginia there will probably be dreadful fighting for the possession of Washington, mons the wise and patriotic like you can stop it.

"We are exemplifying the fable of the dispute between 158 
the head and tail of the snake for the right to leat. The Democratic party is the natural and the mly possible government of our Demoratic confederation. It alone has ever nnderstood the idea of State rights. The tail has taken its turn of lealership, and you see to what a pass it has brought the country.

"Were it not for the immediate question of the fighting to grow ont of the question of the possession of Washington, I should say it were hest that the border States should now all go at once, so as to make the North fect the absurdity of further prosecution of war. But remion is now, I fear, scarcely to be hoped for!

"My wife sends you her affectionate regards.

"Ever yours, "J. L. O'Sullivan.

"The great question for me here of the success of our copper establishment is not yet decided. I had expected to find the works in operation. They will not be ready to begin short of a week or fortnight, and then there may be further delay from changes required in details of machinery. Everything is very encomraging. I have good prospects of a contract for rifles and artillery from this government-it is under consideration now. Could not do anything at present in France, though the plan was recognized as superior to their own or to anything known. But in the present state of Europe they conld not introduce a change, their existing armament on their own plan being on so vast a scale. But I was encouraged for a later day.

"In regard to polities, I suppose the North will be too hot to hold me hereafter, if the papers are right in their account of the Northern feeling."

\section{VAN BUREN TO MOSES S. TILDEN}

"Lindenwald, May 13th, '61.

"Many thanks to you, my dear sir, for the compliment conveyed in rour obliging letter.*

"But be assured that if the time ever arrives for the con-

* It is presumed that the work here referred to is an account from Van Buren's pen of the administrations of P'resident Jackson and his own. It is greatly to be regretted that Mr. Van liuren did not, to that extent, at least, become his own biographer. 
sideration of such a work there is another man in this State who could do it far more justice than I could hope for, and that is your brother Simuel. For myself, I shall for the rest of my life have but one thing to tinker on in that way, and how that will fare in these troublesome times is, I fear, rery doubtful.

"Do me the favor to present me very kindly to your good sister and all the other members of your family, and to believe me, as ever,

Your friend, "M. Van Buren."

\section{MR. TILDEN'S WAR RECORD}

His patriotic address to a regiment in 1861. Published in New York Tribune, November 3, 1874:

\section{"New York, Nov. 2, 1874.}

"Sir,-On Saturday afternoon, June 22d, 1861, a stand of regimental colors-the gift of its Democratic friends, merchants and others-was presented to the 37th Regiment, N. Y. S. Volunteers. The colors were presented at the Battery, the regiment then being drawn up in line, and being at the time ready to depart for the scene of war, which it did on the following day.

"There was some ceremony at the presentation of the flags, and several speeches were made. One of the speakers on the oceasion was Mr. Samuel J. Tilden, who made a stirring appeal to the officer's and men of the regiment-a speech not excelled in patriotism by any public speaker during the War of the Rebellion.

"The writer of this letter knows whereof he affirms, for he was also present and took part in the presentation ceremony. (Signed) Jonn T. Agnew."

\section{J. L. O'SULLIVAN TO TILDEN}

\section{"Lisbon, June 5, 1861.}

"Mr dear Tilden,-I have not yet a word from you, and should feel more angry than $I$ do at such a cruel silence were it not that I fear you must be sadly harassed and oceupied with your private affairs, superadded to the afflictions of the patriot. Sinee my last letter I have seen in the papers reason for some mitigation of the extreme disgust and indignation I had before felt in regard to the conduct 
of the lemoeratic party at the North. I hald all lut forsworn it, supposing that it had all grone over, bag and baggage, into this worst form of Republicanism, which consists in the support of this insane and wicked war, and that, eonsequently, no possible place remained for me, even in a corporal's guard, left of it. But I see in the newspaper letter from New Iork the cheering expression that "the Daily News, by taking a strong Sonthem view, has largely increased its cirenlation, which show's that people like to see what ean be said against the war, if they to not agree with the opinions expressed.' 'This assures me at least that even though I might be nyyself hmmg for a traitor in the strects of New York, for my sentiments on the subject, there would still remain somehody willing to cut me down and give ne decent hurial. I now look with great anxiety for the Democratic State convention called for the 4th of $\mathrm{J}_{11} \mathrm{y}$, though what it can do to resuscitate the suieided body of the old party I do not see. I beg yon to go to the oftice of the News and subseribe for their weekly paper for me, with the back numbers for the period since the beginning of the war. Do the same in regard to tho Day Book. Let them be directed to the U. S. Legation, Lisbon, through care of .John Miller, U. S. Despateh Agent, 26 Henrietta Street, Covent Garden, London. Subscribe, also, for the Weelily Post. I must get you to advance the payment for these subseriptions for me, which I will repay. The Herald I see here through another channel. The Post I want only, of course, for the object of seeing the talk of the enemy. Do tell me all your own mind on the snljiect. I am frankly and decidedly with the South now in their stand of resistanee against subjugation and for independence. Whatever antecelents may have led up to it, that stand is now rightful and honorable, and sulmission would be pusillanimons and base, while in those very antecedents four-fifths of the wrong has been on the Northern side. This war against States constituting nearly half of the Union is an entire violation of the whole spirit of the Constitution, as well as of that of the law of '95, under which it is made. It is the Sonth which is now fighting in defenee of all the principles and rights of Ameriean liberty, for self-govermment and the dignity of man, and even though it should be conquered and subjugated the Union of foree and military centralization thence to result would be in itself a worse political evil, and more pregnant 
with future mischicf, than would be now a confirmed separation. However, therefore, I may deplore, with heartbroken grief and shame, all the disasters of these fratrieidal battle-fields, ret truth and justice and convietion extort from me the avowal that I hope the South will be suecessful in beating back from their own rightfully defended soil this most fatal and iniquitous invasion; and for this sentiment, though it may be the extreme of treason, I am willing to stand responsible before God and man.

"God bless you, my dear old fellow, whether you now go with me the full length of my opinions, or whether I may have to regret, as a sensible addition to all the rest of $\mathrm{my}$ present affliction, that we no longer stand united in our old aceord of sentiments. Eadem sentire de re publica. Just as I would hare shouldered a Northern rifle to unite in the defence of Thashington against menaced invasion from the South, so would I now, were I at home, stand up in aid of the rightful defence of the Southern soil against this equally unjustifiable invasion from the North; and this, were $I$ on that side of the Atlantic, or were it possible for me to get there, I would do, unless I could do better service to the cause of the right by speaking, writing, and acting for it at the North. It is only the foolish and mad eo-operation of the deluded Democracy that has enabled the Republican administration to undertake this war, and now enables it to earry it on. In that sense the Democratie party is, though secondarily, as much responsible for it as the Republicans. If it were now to draw back and insist on peace, it has the power to enforce that policy. This is what I would labor for, and it is with a view to this that I have written to urge my views upon you and upon the public, so far as you may have consented to publish my letters, every word of which I should be glad to see in the columns of the News or of the Day Book.

"Ever faithfully Yours, “J. L. O'Sullivan."

\section{J. D. ANDREWS TO TILDEN}

" Private.

"National Hotel,

"WASH'G., Aug. 18, 1861.

"MY DEAR SIr,-The wheel of publie events is rolling rapidly, and soon the good men of the country will have to 
combine outside of President and Cabinet to protect the national honor and save our institutions.

"Seward is premier and President, and under his weak, mischievous rule the ship of state is rapidly approaching the breaker's. He nor the rest of the Cabinet have any administrative ability, nor any comprehension of the immensity of the erisis. They are all governed by a narrow policy, and are so intent upon personal objects that the higher duties of the citizens are made subordinate in this emergency of a nation's life to the suceess of the partisan.

"Seward is the great failure, but he is egotistical, false, flippant, grotesque as usual.

"Chase is equally vain and selfish, but more just, bchind a rampart of dogmatic egotism. Of the rest it is unnecessary to speak, but of Blair, who is the weakest and most mischicrous of the whole set.

"We are in the presence of mighty events, and under the rule of pigmies.

"Our foreign relations are in a critical condition, while Seward has not the grasp to eomprehend nor direct them.

"The maladministration of the War and Navy depts. is in full force, while corrupt odors are continually exhaled.

"The army is in a disaffected, disorganized, discouraged condition, and not in good trim for service, chiefly through the utter incapacity of Cameron.

"The expenses are a million a day, which will not be patiently borne, no matter who the people are, without corresponding results.

"There is a feeling of gloomy dread in the public mind here of coming misfortune, and let me ask you what will be the effect upon the public opinion of the North if this city should be taken. The enemy is in great foree, daily increasing, victorions, defiant, and in spirit and condition to be aggressive. If he does not soon attack the capital he will be restrained only by prudential or political considerations.

"The North may as well, however, look that probable event square in the face. Thus, after a rule of five montlis of this wretched Calinet, with a great nation supporting it, with imperial resources at command, approved and animated by a self-sacrificing patrintism rarely equalled, we are disgraced, dishonored before the world, and seareely in a condition to act bravely on the defensive. Soon France and 
England may interfere, and then, pray, what is our condition?

"You will probably remember what I said at our first meeting at the hotel of the strength and resources of the South, and of the incapacity of this Cabinet to grapple with the palpitating hearts.

"I am no prophet, but it seems as if we are only approaching a mighty revolution.

"I am mortified and humiliated that the great, brave American people have such representatives at the head of their govermment.

"For what are we fighting? Congress has no voice, except of adulation for political paramours, and this quailing, squirming Cabinet is dumb.

"I have never even seen Lincoln. Mr. S. told the other day that a Western gentleman of distinction said to him: 'Unless you soon ehange this Cabinet the people will change you, and it-'

"The New York papers are congratulating the country upon the loan. That is well, and I am gratified at the confidence in the honor and resources of the nation, ret regretting that the bankers did not make conditions, knowing that ineapacity and raseality sit enthroned at the head of the War and Nary departments. Banks, it is said, has been ordered to adrance his lines nearer the Potomac. MeClellan is doing as well as he can-has good administrative ability. 'Tis said the lines are widening between him and Scott. Scott is infirm, and falls asleep at a brief talk. Chase is chiefly responsible for placing McDowell in command of the advaneing army-and thus of our defeat.

"Please give my kind regards to Judge Pierrepont and Barbour, and with best wishes, I remain, "Your friend \& Serrant,

"J. D. Andrews.

"Saml. J. Tilden, Esq., New York:"

GEN. JNO. $\Lambda$. DIX TO TILDEN

"Baltimore, 3 Dec., 1861.

"My desr Sir,--I was mueh gratified by the receipt of your letter. The proclamation was issued and distributed in Accomae before I sent copies to the President and Genl. McClellan. On a few important oceasions in life I have 
acted withont comsulting any one. Where my convictions have been so strong as to give me an muloulting assurance that I was right, I have foreborne to eonsult others for fear they might differ with me. I do not know that Genl. MeClellan approves all 1 have done. I am not sure as to the President, though I think he regards my policy as the trine remedy for the special plase of the malarly of secession, which existed on the eastern shore of Virginia. Whether he will regard it as the proper treatment for other phases of the disease I do not know. If our madmen in Congress, when everything is prospering, adopt Summer's miserable scheme of emancipation or .John Cochrane's diabolical project of arming slaves against their masters, all hope of a pacification will be at an end. Kentucky, I fear, will instantly array herself on the side of the Confederates. The conservative men of the country must make themselves felt in Congress and without a moment's delay.

"Ever sincerely yours,

"Hon. Samt. J. Tilden. John A. Dix."

"P. S.-When I eame here, four months ago, I ordered all my colonels not to allow negroes to come within their encampments. This rule has saved me from all annoyanee. The only diffieulty I have had grew ont of the reception of a fugitive slave against my orders.

"N. B.-I send a correct copy of my proclamation. There were rerbal inaccuracies in all the published copies in $\mathrm{N}$. Y."

The proclamation here referred to was dated November 13, 1861, and addressed to the people of Accomac and Torthampton counties, Virginia. It ran as follows:

"The military fores of the United States are about to enter your counties as a part of the Union. They will go among you as friends, and with the earnest hope that they may not, by your own acts, be forced to become your enemies. They will invade no rights of person or property. On the contrary, your laws, your institutions, your usages, will be scrupulomsly respected. There need be no fear that the quieturle of any fireside will be disturbed, unless the disturbance is caused by yourselves.

"Special directions have been given not to interfere with the condition of any person held to domestic service; and, in order that there may be no ground for mistake or pretext 165 
for misrepresentation, commanders of regiments and corps have been instrueted not to permit any such persons to come within their lines."

MEMORANDUM LEFT BY MR. TILDEN

Mr. Jolm Van Buren, who had become an earnest supporter of the war, just hefore he made a speech at a great Demoeratic meeting in the city of New York, in October, 1862, called upon Mr. Tilden.

"We must be for the war," said Mr. Van Buren.

"Certainly," replied Mr. Tilden.

Mr. Van Buren showed a letter from General Scott, in which he proposed to "let our erring sisters depart in peace." Mr. Tan Buren conld not resist the temptation of making an oratorieal point upon the letter of the great military chieftain, and read it to the meeting. An andience applauds point more than reason. Mr. Yan Buren was an orator who sported with the tumultuous sympathies of a popular assemhy, as a daring horseman rides a fiery steed. In the action and reaction between the speaker and the anditors, Mr. Van Buren, contrary to his intention, was carried into some seeming indulgence towards General Seott's idea. The impression was not satisfactory to his friends or to the leaders of the Democratic party.

At a casual meeting, at which were present Mr. Dean Richmond, the chairman of the Democratic State Committee, Mr. Seymour and Mr. Jones, the Democratic candidates for Governor and Lientenant-Governor, Mr. Tilden was consulted. He disapproved the aspect in which the last meeting had left the matter, and suggested that, as Mr. Seymour was to speak in Brooklyn on the evening of the next day, he should at the close of his speech make a more correct and an anthoritative statement of the Democratic position in respect to the war.

Mr. Tilden was requested to reduce to writing what he suggested should be said. The next morning, on his way down-town, he left with Mr. Seymour a sketch of a peroration for the speech to be made that evening.

It was in the following words: 
"And now, if my woiee conld reach the Sonthern people, through the journals of our metropolis, I would say to then that in no event ean the trimmph of the eonservative sentiment of New York in the election mean consent to disunion, either now or hereafter. Its true import is restoration, North and South, of that Constitution which had secured every right, and muder whose shelter all had been happy and prosperous mitil you madly fled from its protection. It was rour act which hegan this ealamitous eivil war. It was your act which disabled us, as we are now disabled, of shaping the policy or limiting the objects of that war. Loyally as we maintained your rights, will we maintain the right of the govermment. We will not strike down its arm as long as yours is lifted against it. That noblest and greatest work of our wise ancestors is not destined to perish. We intend to rear once more upon the old and firm foundations its shattered columns, and to earry them higher towards the eternal skies. If the old flag waves in the nerveless grasp of a fanatic but feeble faction to whom you and not wo abandoned it, we, whose courage you have tried when we stood ummoved between fanaticism and folly from the North and Sonth alike, will once more hear it onward and aloft until it is again planted upon the towers of the Constitution, invincible by domestic as by foreign enemies. Within the Union we will give you the Constitution you profess to revere, renewed with fresh guarantees of equal rights and equal safety. We will give you everything that local self-govemment demands; everything that a common ancestry of glory -everything that national fratemity or Cluistian fellowship requires; but to dissolve the federal bond hetween these States, to dismember our conntry, whoever else consents, we will not. No; never, never, never!"

\section{JOIIN A. DIX TO TILDEN}

"Hendquarters of the Mmy Corps,

"Font Monkoe, VA., i sept., 186?.

"Mry dear Sir,-Your letter by some mischance got among those intended to go by flag of truce to Richnond, and I only received it the day before yesterday. Yesterday I wrote to Judge Pierrepont, saving that I camot relinquish my position in the field. There is only one condition (and that an impossible one)-a call from the people of New 
York on me to be their Chief Magistrate for the purpose of carrying, if possible, greater vigor into the conduct of the war. I say this is impossible, beeanse I see elearly that the Republieans will not relax their hold on anything they possess, and that the Demoerats are taking the field under their old and everlasting office-seekers. I see no good to the country from such a contest, and I cannot go into it.

"Sincerely yours,

"JoHN A. Dix.

"Saml. J. Tilden, Esq.

"Consider this confidential."

HORATIO SEYMOUR (RECENTLY ELECTED GOVERNOR)
TO TILDEN

"Utica, Nov. 10, 1862 .

"Mr dear Sir,-I have a very high opinion of young Mr. Ketcham. I have made partial arrangements about my secretary, but I hope it will be in my power to serve him in some other way. I wish you would so advise him.

"Now that you and others have got me into this scrape, I wish you would tell me what to do. Give me your suggestions. I shall need all the help my friends can furnish. It looks to-day as if the administration intended to push forward without regard to public opinion. If they do, the financial rope will hang them up.

"In haste,

"Truly yours, \&c.,

" Horatio Seymour.

"Hon. S. J. Tilden."

TILDEN'S INTERNAL REVENUE TAX DURING THE WAR IN 1863

“Collector's Office, 163 5th Av.

and

“ 937 Broanway, cor. of $22 \mathrm{~d}$ St.

"U. S. Internal Revenue,

" 8th District, State of New York.

"Mr. S. J. Tilden,

"NEW York, 1863.

"No. 2 Union Square. Street.

"Your tax on income......................

and on enumerated articles................ \$2.00

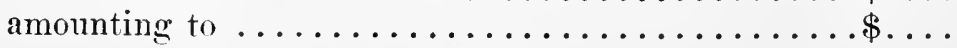


as returned by the assesson of this district is due, and should be paid at once. Sankable money or checks required. Office hour's from ! A.x. to : P.x.

"Please bring this with you.

$$
\begin{aligned}
& \text { "Yours respectfully, } \\
& \text { "G. P. PuTnam, " }
\end{aligned}
$$

AUGUST BELMONT TO TILDEN

"NEw YoRk, January 2\%, 1863.

"MY deAr Sir,- When you have done with the paper which I gave you at Albany will you be kind enough to send it to me at your convenience?

"Don't you think it is high time for the conservatives to go to work and make a powerful demonstration in our eity and State in order to compel the administration to a change of measures and men? If nothing is done, I see but ruin and national bankruptey before us. Could not Gov. Seymour send a strong and determined message to the Legislature, recommending immediate measures for a convention of the centre States, with such others as may favor us?

$$
\begin{aligned}
& \text { "Yours very truly, } \\
& \text { "August Belmont. }
\end{aligned}
$$

"NEw YoRk, January 27, 1863."

\section{R. II. GILLETT TO TILDEN}

"Wasinington, 22 Feby., 1863.

"MY DEAR Sir,-T have just read your letter of 1860 to Judge Kent. It is full of wisdom and aceurate prophecy. I wish it could be read by all reflective men of the old Union. Until we act upon the theories there developed, our country must submit to the evils which error has brought upon us. Nore fatal delusions never led mankind than guide the party in power. Until they give place to reason, sound sense, and honesty there will be no relief.

"In one of the addresses issued by the executive committee here, in 1860, prepared by me, there is a prediction of the fatal consequences of elevating to power a representative of the prineiples of those who nominated Lincoln. I was, it is true, unwilling to believe what my reason told me was inevitably true. But I felt bound to proelain the convictions resulting from much reflection. But our countrymen 
Were mad, and like mad men would heed no warning. The fatal error was committed, the consequenees of which no one can calculate. But you, at least, are not responsible for the result. Yon did all that one man eould do to direct to the path of safety. I tried to do mine, but met with no success in nuaking converts.

"I fear there is a disposition on the part of many of our friends to take and act upon a mistaken view of our present dutc. The 'peace policy' of many will prove fallacious. I would go with the sword in one hand and the most liberal measures of reconciliation in the other, while I would require all, in and out of authority, to observe the Constitution and the rights of all citizens, and punish all infractions where possible to do so without regard to station.

"After our court adjourns I intend to go to Lebanon, and hope to see you when going or returning.

"Yours truly, "R. H. Gillett.*

William Chauncey Fowler, a son of Reuben Rose Fowler, was born September 1, 1793. When four years of age his parents removed to Durham, Connectieut. He graduated from Yale College in 1816, became a tutor in 1819; two years later he beeame pastor of the Congregational Church in Greenfield, Massachusetts. In 1825 he became professor of chemistry and natural philosophy in Middlebury (Vermont) College, whence he resigned to take the chair of rhetoric and oratory in Amherst College in 1843. In 1825 he married the daughter of Noah Webster, and edited for his father-in-law the university edition of Webster's Dictionary. He served in the Legislature of Massachusetts in 1851, and in the Senate of Connecticut in 1864. His English Grammar was extensively used as a text-book in the schools. He was a member and ehairman of the school board in Durham for twenty-five years. He died January 15, 1881.

* Mr. Gillett was a neighbor, a friend, and the authorized biographer of Silas Wright. His letter is only interesting as another illustration of the diversities of opinion among the spectators, about the first thing to do when the neighbor's house is on fire.

The letter of Mr. Tilden to Judge William Kent first appeared in the Evening Post in 1860, and was republished in the New York World in 1863 . 


\section{WILLIAM C. FOWTER TO TILDEN}

"S. J. Thlodex, Eso.

"Durinam Centre, Conn., Feb.

"DEAR Sir,-I have just risen from the perusal of your" letter, addressed in 1860 to Professor William Kent, and published last week in the New York World. The pullic were and are under obligations to you for this satisfactory and patriotic expression of your sentiments; and, for one, I beg leave to express my thands. The opinions you expressed have been confirmed, and the prophecies reeorded have been accomplished by the thick-eoming events of the last two rears.

"But, unfortunately, it has been the fate of us "unionsavers' that our prophecies have been dishelieved, as were those of the fabled Cassandra when she foretold the ruin of Troy.

"Can the North understand the full import of the federation idea?' This question of yours is pregnant with meaning. It did once understand it. But two or three generations sinee that time have passed off, or are passing off the stage, and this idea has gone with them. Can the country be restored to 'its first love,' and do its 'first works,' and thus preserve the Constitution and the Union?

"I have read the remarks of Prof. Norse and Mrr. Curtis and yours with the same satisfaction with which I listened to them at Delmonico's.

"Very truly and respectfully yours,

$$
\text { "Wintiail C. Fowler." }
$$

\section{GEO. A. TIIURSTON TO TILDEN}

" How. S. T. Thlmen.

"Cumberland, Maryland, Fcby. 23, 1863.

"Denr Sir,-I reecived, and have read most earefully and with great interest, your 1 s60 letter to the IIon. Judge Kent, which recalled to me some riews you expressed at Mr. Stonghton's dimner-table during the conversation that ensued between Mr. Strmghton, Mr. Collector Sehell, rourself, and myself. I numst confess your predictions, both in the letter and what fell from you in that eonversation, which have since heen fulfilled, astonish me, and compel reluctant admissions of your superior political sagacity. Still, the worst, that is, most injurious consepuenees forotold hy gon have not yet 
oceurred; and though I hesitate somewhat in my views and hopes from perceiving how much I did not expect, nor even apprehend, and which you asserted would happen, have resulted as you predicted, I am yet sanguine enough to believe what is still unfulfilled will remain so during our day at least; and then, after us, 'the deluge.' Allow me to subscribe myself, Faithfully and trily Y'rs, "Geo. A. Thurstox."

\section{TILDEN TO J. J. TAYLOR*}

"New York, Feb. 26, '63.

"MY DEAr SIR,-The truth is that the plan of the Society for the Diffusion of Political Information is not completely matured. It had not become a movement of much importance or definiteness of aim when it was brought into sudden notoriety by the attacks of the extreme Republican press.

"I send you a copy of the Constitution, with Mr. Curtis's introductory address. Your suggestions as to the character of the publication are good, and, I think, in accordance with the intentions of the society.

"I do, indeed, feel strengthened in the general views of public affairs which I take by the concurrence of a thoughtful and instructed mind like yours. The calamity of our times is that the people have outgrown their knowledge of their own civil institutions-in some sections of our country.

"I add a copy of the letter to Mr. Kent, which has been drawn into some renewed notoriety by the attacks on the Delmonico meeting.

$$
\begin{aligned}
& \text { "Very truly, f } \\
& \text { "Your friend, "S. J. Tilden." }
\end{aligned}
$$

\section{H. HOGEBOOM TO S. J. TILDEN}

\section{"Private and confidential.}

"S. J. Tilden, Esq.

"HuDSON, June 18, 1863.

"Mr DEAr Sir,-It has occurred to me that it would do no hurt if it did no good to make some further suggestions on a topic which we discussed a little in New York-to wit., the expediency of my changing my residence to that city, or

* Mr. Taylor was appointed Harbor Master of New York, in Jan'y, 1873 , by Governor Hoffman. 
of connecting myself in a business way with some gentloman there, continuing ny present oflicial position or not till the expiration of my term as should be thought advisable. I have so much confidence in your good judgment, as well as command of large business interests, that it has necurred to me whether some sort of professional connection conld not be established between us to our mutual adrantage. You must have at times more than you can attend to, and, besides, will find it neeessary to consult your health and allow yourself more leisure. On the other hand, my health is pretty firm, and my disposition to labor unabated. I make the suggestion for your consideration, and shall accept in the best feeling any suggestions you make, whether I suppose them to tend to my interest or not. I should be desirous if I went to New York to connect myself with large interests, if possible, and am persuaded no one in that respeet is more advantageonsly situated than yourself. And I am convinced that with the close of this mhappy war (if it ever does terminate) those interests with which your business is more directly connected will receive a decided impulse, leading to a large and lnerative increase of professional interests eonneeted with them. Becides, such connections must place one at times in a position to make profitable investments, and in many other respects are to be desired. If such an arrangement could be made, I would be disposed to do what was, on the whole, thought advisable as to the time to enter into it. And if a business comnection would not strike you as favorable to the interests of either of us or of yourself, I think you might make useful suggestions in regard to the matters here hinted at, as you already have done. I pray you to have no delieacy on the subjeet in saying what occurs to you as proper. Nor let the pendency of the case before me, in whieh you are comnsel, have any influenee to deter you. In such matters 1 profess entire independence, and while I never suspeet the slightest attempt on the part of a friend to influenee me, often disappoint my best friends in the conchusions at which I arrive. In that matter at present I have positively no decided opinion whatsnever. May I hear from you at your convenience, and ask you to treat this as confidential?

Truly Yours, "H. ПГовевоом."*

* Mr. Hogeboom was a lawyer in Hudson, Columbia County, of which county Mr. Tilden also was a native. 
" 50 \& 52 Howard St., New York Citr, July, 1863.

"Dear Sir,-The Legislature of this State, at its last session, made a liberal appropriation for the protection and relief of soldiers returning from the war. Under this appropriation, the New York State Soldiers' Depot has been established and located at Nos. 50 and 52 Howard Street, New York, and we beg to call your attention to the objects of the institution, and to solicit your co-operation in carrying them into effect.

"The board of managers consists of the Adjutant-General of the State, the Inspector - General, the Surgeon - General, and the Quartermaster-General, and their action is subject to the supervision of the Governor.

"The depot is a spacious building, containing every convenience for the accommodation, health, and comfort of the inmates. Food and lodgings are furnished to them free of charge; they are washed and cleansed, and provided with clean underclothing and with transportation to their homes.

"The sick and wounded enter the hospital department and receive careful medical treatment until in a condition to be forwarded to their residences. If any die at the depot, their remains are transmitted to their friends. The system of station agents and train comriers adopted by the board effectually protects the returning soldiers from robbery, imposition and vice.

"It is unnecessary to dwell upon the advantages of such an institution.

"It secures immediate relief to the suffering and needy men who return sick, wounded, and penniless from the war. It removes those who possess health and money out of the reach of the temptations of the city, and protects them from the impositions so generally practised upon returning soldiers, who are specially marked as the prey of the dishonest. Its effect will be to induce re-enlistments, for it will prove to the volunteer that the State will not forget or neglect those who fight in defence of their comntry.

"The board of managers, being desirious of having the advice of some of their fellow-citizens in the prosecution of their work, have concluded to form an advisory committee. 
You have been selected and are invited to act as one of that committee.

"You will always be welcome at the rooms of the depot. "Very truly Yours,

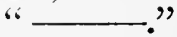

GEO. T. CURTIS TO TILDEN

" Rockaway, Friday, 1\%th July (1863).

"Mr dear Sir, - I was obliged to leave town suddenly on Tuesday, as my family were expecting me by a certain train, and were in a little cottage here without any other male protector. I do not expeet to go to the eity again before Monday. I have read the eity ordinance. After much reflection, it seems to me that there are two or three modes of raising the legal question; and I take it for granted that the State anthorities, if the draft is pressed, will act only in support of their own judicial process. Does not the jurisdiction of our Supreme Court, in General Term, admit of a writ of prohibition, to be applied for on the ground that certain persons, ete., are about to enroll, summon, and sulbject to martial law A. B. and C. D., eitizens of New York and members of its militia, etc., etc.? This would avoid all diffienlty abont the hab. corpus. If it be said that a prohibition out of a State court cannot control a Federal officer, I think it is suffieiently answered if the prohibition is founded on the allegation that the Federal officer is undertaking to act under eolor of a law constitutionally invalid. The process and the case may be afterwards drawn into the Federal judicial power for revision. But it may issue and may be served, and then there is a legal process and not a mere forcible resistance.

"The Federal court, too, las probably the same jurisdiction, althongh I have not the means here of looking at that. I slould think Judge Nelson would eome to town if requested.

"It will, of conrse, be understood that $I$ am prepared to discuss the question in any contt, if my services are needed.

$$
\begin{aligned}
& \text { "Y's very truly, } \\
& \text { "Glo. T. Curtis."* }
\end{aligned}
$$

* A lawyer from Watertown, Mass., who settled in New York city, and was the author of several studies of the Federal Constitution, of The Last Years of Daniel Webster, and The Law of Copyright. In the Civil War his sympathies were with the insurgent States. He died in 1894. 
" Pinca., July 21, '6.3.

"DEAr Sir,-The suspense here to have the adjudication of rour courts upon the constitutionality of the conscription act is painful. If the comrts shall hold that this enactment is outside of and overrides the Constitution, our people in Penn'a will sustain that position. On the other hand, if the courts shall hold the act constitutional, rather than resist law and invoke anarchy, I do not think there will be any other opposition than sporadic outbreaks and a general fleeing to avoid the compulsory service. I write to ask you that for the sake of the public peace, and I may well add for the sake of republican liberty on this continent, you give your best efforts to obtain a speedy decision on this subject. I take the liberty of thus addressing you becanse of our former (to myself) very pleasant personal acquaintance, and because of my knowledge of your professional and political position. I feel confident you will agree with me that unless sufficient courage comlines with patriotism and a comprehensive appreciation of pending movements to overthrow constitutional liberty in this sorely afflieted country, we will soon have to mourn the establishment of the most absolute despotism.

$$
\text { "Yours Very Truly, }
$$

"Pinila., July 21/63.

"Please address me at Pottsville, Pa."

GEO. T. CURTIS TO TILDEN

"NASSAU ST., July 2/ (1863).

"Mr denR SIr,- - I have revised the opinion wh. I gave to the Governor last March on the conscription act, and have since thought of publishing it as an opinion given to the Governor at that time. ITe has been bitterly assailed for having spoken of the 'rights of the people.' I want the public to see the grounds for the opinion that the people have rights, which have been violated. I should not, however, print this opinion if the state of things, in the negotiations with the gort., makes it inexpedient at the present moment. But I mean to get it fully reary, and to let it be 
known what I think of this law as soon as there is a fitting time for it. Will you mention this to the Governor? I shall be in town again on Monday.

$$
\begin{aligned}
& \text { "Y'rs truly, } \\
& \text { "Geo. T. Cuntis." }
\end{aligned}
$$

The National Intelligencer was the organ of the old Federal and Whig parties almost from the foundation of the government. It was a faithful champion of the slave-holding interests of the South until its representatives in Congress withdrew from the Union. The demise of the Whig party by the incorporation of the Northern portion of it into the Republican party and the separation of the slave States from the Union, left the Intelligencer no longer any constituency, and after a few struggles like the one of which we read in the following letter from Mr. Kennedy, and a brief, precarions existence which Mr. Tilden contributed financially to prolong its publication was discontinued.

\section{J. C. G. KENNEDY TO MR. POND}

"WAshington, July 25, 1863.

"Desr Pond, - I have been credibly informed to-day that mless they shall be so fortunate as to receive immediate relief from some friendly source, the Intelligencer will actually be suspended in the course of the coming week.

"The paper, it is generally known, beeame embarrassed" by the entire loss of its large Southern cirenlation, consequent on the rebellion, which loss has been followed now by the withdrawal of the official advertisements of the govt. departments, which they have hitherto enjoyed under almost every administration, thus entting off resourees by which they have managed to meet their expenditures, and rendering imminent an event which of all others will gratify the ultra party of the country and bring mortification on the conservatives which they will deplore when too late to be remedied. Its fall will exhilarate the abolitionists by the assuranee it will appear to justify, of the opposition to extreme measures, and the inalility of the conservatives of the country to sustain a jommal at the seat of govermment opposed to radicalism, and practically confirm the standing and inerease the influence of the radical press here, while it will deprive the 
comtry of a tried and faithful watehman on the walls of the eitadel whose very presence intimidates from a surrender of the bulwarks of the Constitution and the constitutional mion. Shall this be? Will the wealthy, patriotic, conservative men of New York quietly permit snch an adrantage to be gained by their destructive adversaries, and suffer to be lost what holds out such a prospect and guarantee of usefulness and necessity to them. when a comparatively small effort may avert such a catastrophe? In riew of the depressing effeet which the stoppage of snch a paper at this juncture will produce on National men North and South and their cause, and the advantages which will inmre therefrom to the sectionalists, cannot some good men of New York make up a loan to the establishment of a few thonsand dollars, which will give it stability and independence thro' the rest of this year, when it is to be hoped a new era will open, thereby maintaining an important element of power for good, in bringing about a reasonable and happy settlement of our difficulties when the force of arms shall have accomplished its work. Will these good people of New York allow this old and influential journal of more than half a century's standing to go down for defending their cause against the destructive poliey of the radicals, and when, if it go down, the conservatives will have to make greater sacrifices in establishing another in its stead which must be long in acquiring the same confidence and power of usefulness? These are questions which must be determined in a few days, or the capital be left without a paper representing and upholding national views and the country be deprived of a faithful journal, which ean be relied on, regardless of government favor, and continue to do its duty to the people unawed by power though it perish in the struggle.

"The amount, if supplied, may be deemed and made a lien on the establishment and apply as a credit on its purchase hereafter, or may be a loan to be secured by deed of trust thereon.

"I have stated facts, with no personal interest to adrance other than as my welfare is identified with the honor and prosperity of the country and the integrity of the Union and the preservation of law and order. I have made suggestions, and can conceive of no act more patriotic or more demanded by the highest interest of the country than the object of my note. 
"I have advised that a confidential agent go to your city", and I am writing to ask you to aid lim by your counsel in putting him in the way to avert an impending calanity. What I write you are at liberty to use according to your discretion, but please kecp ny letter in your sole possession. Ify engagenents preclude ny leaving home at present, and I write as I would speak and would wish to say to men who will readily be sugrested to your mind. Can you say it for the comntry's sake, and at onee?

$$
\begin{aligned}
& \text { "Yours faithfully, } \\
& \text { "Jos. C. G. Kennedy." }
\end{aligned}
$$

WILLIAM B. REED TO TILDEN

"Pinlad., July 28, 1863.

"MY Dear Srn,-Our proposed litigation here, as to the conscription law, has thus far failed-from want of courage on the part of the litigant, whose chance of suecess, within the law, was not very encouraging, and whose donm, in the event of failure, was very certain. The form whieh was adopted by Mr. Ingersoll and Mr. Wharton was that of an injunetion bill against the enrolling and drafting officers, and the hearing hoped for was before the court in banc. I now very much doubt if it will be resorted to. A habeas corpus before a single judge on the receipt of notice, which constitutes a technical custody, seems to me preferable.

"'The draft, in the mean time, is going on and, I confess, I am puzzled by the apathy with which it is reeeived, especially in eommection with the admitted fact that New York and probably New Jersey are to be exempt. Still, I think there will be an outbreak whenever the actual kidnapping begins.

"Of course you see or think you see the dangers which threaten you more elearly than we at a distance do. But the apprehension is very prevalent here that Gov. Seymour is in danger at any monent of seeret arrest. Things of that kind have been hinted at, and eertainly I saw nothing in New York to make such an outrage practically difficult. There is inducement enough, for his removal puts the whole Democratic North under the heel of the radieals. My theory about arrests is that they are always fatal. No public man ever recovered from the stain they scen to inflict. I donbt very much if $\mathrm{Mr}$. Vallandigham will ever recuperate. Gov- 
Seymour is the only public man who at this moment stands in the way of a eentralized despotisun, and him a small guard of Federal soldiers could easily and seeretly remore.

"I am, no doubt, very nervous and very suspicious, but, I assure you, these facts are not confined to my own bosom. "Very Truly Y'rs,

"S. J. Tilden, Esq., New York."”

$$
\text { "Winllaje B. Reed. }
$$

\section{TILDEN TO HENRY HOGEBOOM}

“New Lebanon, July 28th, 1863.

"MT DEAr SIR,-I have been peculiarly unlucky in the attempt to answer your letter of June 18th. It came on my return from an absence from the city, followed immediately by another; and then by an illness which wholly disabled me for a week, and from which I emerged only after the commencement of the riot, and that brought upon me many demands for attention and counsel amid ten days of excitement and bustle. I turn to it as actually the first real business of my own to which I have had a chance to attend for some weeks, indeed, since the 4th of July, when I had begun an answer, until now. I came here Saturday evening, and expect to return to-morrow morning.

"How swiftly events move, and how greatly they change! I am reminded, as I see by what I began to write, how deeply a few weeks ago I was involved in solicitude for the results of the military operations then reaching their crisis. At no time since this war commenced have I been so disturbed as before the battle of Gettysburg; a different issue of which might, in my judgment, have put us on our defence even as far as Phila. and New York, and brought a revolution in our thoughts and occupations, and since that New York has been npon the verge of a social peril, at that time wholly unexpected.

"I appreciate the frank and cordial spirit of your letter, and shall state my own impressions in the same confidence which you express that our long knowledge of each other will, at least, secure us a perfect mutual understanding. I say impressions, for I am conscions that all my views of the future, for myself, and for all others in whom I take interest, may be colored by the peculiar uncertainties which now enshroud our horizon. 
" 1 . While I think it proper for you to keep your eye upon the opportmity of forming a future business in $\mathrm{New}$ York, I doubt if you can prudently abandon your present sure and honorable position, or can coint with sufficient certainty upon events to enter at present into definite engagements of so much importance to your interests and happincss. I think you will renember in all our conversations a disposition on my part (arising, perhaps, from the habitual caution which my views of public events inspire) to contemplate snch a change in your affairs as taking effect after the close of your present term of official service.

"I think, if the battle of Gettysburg had happened to be such a disaster to us as is always possible in the vicissitudes of war, business in New York would have been for the time, and how long a time I know not, suspended. Who can eompute the consequenees of the loss of Washington, Baltimore, and, perhaps, Philadelphia? Nor can I be insensib]e to the social disorders to which great eities are exposed during such civil convulsions as our country is now undergoing.

"You are at present sure of a livelihood by a temure and in a geographical position which are not affected by the military, political, or financial vicissitudes to which all business in the eity of New York is exposed, and which might fall with peculiar severity upon a newly formed enterpriseundertaken in reliance upon profits which any of thesc causes might render illusory, and amid expenses which eity life and eity business inevitally involve. Under these circumstances I hope you will not consider it officious if I express the opinion that it would be wiser for you, holding to your present certainty, to await events which ean searcely fail to shift greatly, if not frequently, before a decision can be practically forced upon you.

"2. I agree with you that after the war shall have closed the city of New York will afford scope for business corresponding to the revivified interests of the country; but I agree with this qualification-that it can hardly be that the transition ean be made, changing, as it will, the application of labor and enterprise from one set of objects to another, without a shock of more or less duration, and that the retirement by any process of the paper issues may be expected to prodnce a period of constantly increasing depression. It will he after this that, with its metropolitan eharacter more than ever assured, New York will return to a state of healthy 


\section{LETTERS AND MEMORIALS OF SAMUEL J. TILDEN}

prosperity, if its position as the trade centr'e of all the States be preserved.

"3. In respect to myself. I am not sure that the advantages of a professional connection with me would be as great as might naturally be expected. It has been the general opinion of the profession that a mere counsel business, of large extent and income, could not be permanently kept up. So far as I have succeeded in doing this, my experience may have been exceptional. I have years ago abandoned all ideas of regular clientage, and could scarcely see any reason why my business should not much diminish, perhaps almost dry up, with the completion of that pending at the time. The substitution of mere business-easy to be deputed, regular in its flow, and almost formal in its nature, which is the basis of large profits in the general experience of the barI have not had, possibly because I had not the organization in my office to do it, and could not do it myself without abandoning the part to which I have devoted myself. If ten years ago $I$ had provided for it what it might have grown to is a matter of conjecture. It is now too late for me to undertake the labor, care or responsibility, or even to acquire the disposition to construct such a business. How far, in lessening my active connection with affairs of the peculiar nature mine has become, I could transfer would be doubtful. Indeed, it would seem to me that some species which have occupied half of my attention for five years past are likely to disappear.

"4. Some years ago I had two suggestions of what seemed to be very flattering connections. One of them was of several intimate friends, who thought we could combine and build up a larger concern than ever existed in this city. I assented to that opinion, but shrank from assuming obligations and necessities which could not be practically terminable at my own choice. Uncertain how long health would permit or necessity require the efforts I was then making, or how long a disposition to continue them would survive the immediate occasion for them, I felt that I should unavoidably part with the perfect freedom of my choice if I allowed friends to build their calculations upon me - that no reservation I could make would exempt me from a sense that what I might prefer to do would disappoint or clamage those with whom I had entered into the joint undertaking.

"In the interval these motives for" keeping free from all 182 
connections have strengthened, while all motives to form them have nearly ceased. The necessities of that day have been fulfilled. IIy health requires an exemption for a time of more or less duration, from the cares which would attend any new engagements, or, indeed, the thought whether or not business is to contimue. Everything that I could endeavor to foresee, whether personal, as health, taste, my remaining here or travelling to Europe or to the far West, or whether public, as financial or political events amid the civil commotions of our comtry - everything, in a word, which could ordinarily form the subject of calculation, seems to be more uncertain than ever before. My habit, therefore, in all things-I scarcely know whether it comes of disposition or of jurloment-is to make no plans at present, except snch as are inevitable; to await erents, and to keep myself as prepared as possible to act, free from engagements and eren from predeterminations of my own mind, according to the changing phases of affairs.

"I have thus, my dear sir, unveiled to you more of my private affairs and thoughts than, perhaps, are known to any other person; for I have written them as if we were talking together, writing my ideas as they arose, without much method or care.

"Please consider them as confidential, and excuse the haste with which they are expressed and the length to which my letter has grown. Aecept the frankness of my revelations and snggestions as an evidence of my cordial interest in your views, and be assured that whatever $\mathrm{T}$ can do by way of information, advice, or suggestion towards your purpose, if you continue to entertain it, will be at all times at your service.

$$
\begin{aligned}
& \text { "Very truly, } \\
& \text { "Your friend, } \\
&
\end{aligned}
$$

"IIon. Henry Hogeboom."

- horatio seymodr to tILDEN

"Albany, Aug. 6, 1863.

"Mr DEsR Sir,-T have been doing all that one overburdened man (an do to adjust nuaters with the general covermment. I am satisfied it neans to go on in a spirit of hostility to this State; that it is governed by a spirit of malice $18: 3$ 
in all things small and great. I do not believe they will accept volumteers on account of the draft. Let it be so. I am willing to accept results. This conscription will make the administration odions and contemptible. It will fail as a measure to raise men. I do not take into account forcible resistance which will aid rather than embarrass government. It will break down because it is impossible to coerce a people. Some will commute, some will run away; many will prove disabilities, and a few will go, enough, perhaps, to demoralize the army. I have sent a communication to the President, written in calm and respectful terms, objecting:

"1. To the fairness of the movement.

"2. To the policy of conscription.

"3. Asking for a test of the constitutionality of the measure.

"It will do no good, except making up a record. I look for nothing but hostility, but I shall do my duty, and demand my rights, and let consequences take care of themselves. I feel no uneasiness.

"Hon. S. J. Tilden."

$$
\begin{aligned}
& \text { "Truly y'rs, \&e., } \\
& \text { "Horatio Sermour. }
\end{aligned}
$$

\section{J. VAN BUREN TO TILDEN}

"Private.

"Lindenwald, Sept. 4th, 1863.

"Mr dear Tilden,-My father left to the col's son Martin a bust of himself by Powers; Smith and I have ordered two copies, or as they are to be executed by Powers, they will in effect be originals. The cost will be about $\$ 500$; something under. They should arrive in October or November. The value of a bust by Powers as a work of art exceeds the sum named. It would be more convenient for me, I am sorry to say, not to take this bust, and I know nobody to whom I would offer it except yourself, or who would prize it so highly. Please drop me a line to let me know if it would be agreeable to you to take it. I need hardly add that this is a confidential matter between us.

"What have you been doing this summer, and why have you not looked in upon me? Thanks to a good farmer, I am promised fair crops and, thanks to the war, they should command fair prices; but I find I have upon my hands an establishment very much beyond the strength of Anna and 


\section{LETTERS AND MEMORIALA OF SAMUEL J. TILDEN}

nyyself, and so distant from my oftice as to cut me off from my profession. I shall be obliged, therefore, to change my arrangements.

"I was glad to see you helped the Tammany Demoerats to keep the the July, and trust you mited in the sound war spirit that scemed to animate their proceedings. IVe hope to be back in th Ave. by or before the 1st. Novr., and shall be glad to see you there if you do not look in on us here before.

"Inndenwald, Sept. 4 th, 1863."

$$
\begin{aligned}
& \text { "Truly y'rs, } \\
& \text { “J. VAN Buren.* }
\end{aligned}
$$

\section{IIIRAM KETCIIUM TO TILDEN}

“ 29 William St., Scpt. 9, 1863.

"Mr diar Sir,-I spent some time last evg. with Mr. Reverdy Johnson at the 5th Avenue Hotel, where he will remain two or three days. He would be gratified to see you. The object which he seeks to aceomplish-the continuance of the Nat. Intelligencer until after the elose of the next Presidential election-is one, in my judgment, of great importance. Should that paper be permitted to go down there will be a rery large number of respectable and influential persons in this country left as sheep without a shepherd. They will have lost the leader which they have been acenstomed to follow, and whose voice they know, for many vears.

"I pray you put forth vigorous and prompt efforts to prevent such a result. I like the views you are reported to have expressed the other day, of miting all the opposition to the present administration in selecting our candidates for the next Presilency.

$$
\begin{aligned}
& \text { "Yours very truly, } \\
& \text { "IIIman Ketcinum." }
\end{aligned}
$$

\section{TILDEN TO JOSEPII S. FAY}

"NEw York, March 2\%, 186\%.

"Mr dear Sm,- In absence from the eity and the oceupations preparatory to it have leferred my acknowledgment of your letter longer than I intended.

"In respect to the first topic of your letter, although we

* Martin Van Isuren had died in July, 1862. 
loth agree in considering it practically past, the desire I have that the real state of facts should be completely understood by you induces me to add a word to our former discussions.

"As nearly as I ean now recollect, the misunderstanding occurred about the time, I think even before, my action in respect to the Peninsula was decided. The false relation between $\mathrm{Mr}$. Ogden and you with the impressions which such of our friends as occasionally met Mr. Parsons derived from him repelled overtures to you. Mr. O. always said that he thought he could satisfy you, but doubted and deferred.

"There never was a moment when $I$ did not desire to communicate with you; but my acquaintance was so slight that I thought it necessary to wait for others, until at last I forced a breaking of the ice, and our interview took place.

"But enough of this. I should not recur to the topic if I had not a great respect for you. The past is gone. We can deal only with the present. That is within our powers. I do not think that, on the whole, we cannot now do nearly as well as if we had done what was best at first. For myself, I have so often felt your reproach for having omitted to promote our understanding, so eapable of benefits to both sides, that I am determined as to the present and the future, which alone are in our power-that the boot shall be on the other leg.

"Coming now to what is the really important part of your letter-put after the fashion of the ladies in the P. S.it must be admitted that if you should meditate anything more than a mere sale on the best security-anything approaching in part to a sharing of the common joys and sorrows of the adventure-the future policy of Peninsular company, in the particulars mentioned by you, would be an important matter.

"I think that policy will be, whether in your society or out of it, conscrvative to your heart's content.

"It would, no doubt, be very desirable to have the terminus of the Peninsular at Escanaba or Sand Point connected with Green Bay by rail. What we can do on that point, and what we cannot, has been definitely announced to Mr. Ogden and others by me assuming to speak for the very solid gentlemen who are the principal owners of the Peninsular.

"If the Northwestern will build that road we shall be 186 
glad. We do not believe the diffieulty of operating it in the winter is any more real than it was supposed to be from Boston to Albiny or from Pierunont to Dunkirk twenty years ago; or as much so as on the Chicago and St. Louis in 1856. There will be a telegraph to Marquette in a few months. An all-rail line to that point would revolutionize the region.

"If the $\mathrm{N}$. W. needs the privileges of our elarter" or the land grant which attaches to the portion of the line from Escanaba to the Nenominee, we ought to aceord them so that we ineur no pecuniary liability for the construction or operation of the line.

"If the $\mathrm{N}$. W. needs that we consent to a modification of the drawbick which it is to allow us on its whole 242 miles for joint business that eomes to or from the Peninsula-we may do that.

"But we eannot dilute our present investment by what will be inferior, though incidentally very desirable to us; or enlarge our undertaking from what we know to be completely within our means, of which we have measured the cost, and exeept to a very subordinate extent fixed it by purehases and contracts. If any of us aid the line south by taking an interest in it, it will be as a separate adventure.

" Tot only has this been our uniform answer to such suggestions, but our present mortgage expressly excludes any extensions south from its provisions in favor of extensions north.

"Now as to extensions north, our poliey would be not less provident. We must feel our way, acepting only what will surely be remunerative and not diluting our investment.

"So mueh in answer to your letter.

"Now a few words in addition on the general subject.

"1. Separately, our charges can scarcely fail to be affeeted 25 cents by the mutual fear of competition, alleviated as much as possible. That all comes from the profits on 300,000 tons; it is the interest on a million.

" 2. In a state of paper-money prices, advancing constantly because of increasing issues, we can protect ourselves only by making rates correspond with daily inereasing expenses.

"This is not apt to be done with sufficient promptitude and holdness.

"You will be and we shall be timid and laggard in meet- 


\section{LETTERS AND MEMORIALS OF' SAMLEL J. 'THLDEN}

ing the exigencies which are before us-from fear of competition and from the delay which always attends arrangements between independent parties.

"3. We should better our condition as to our land grants if our efforts were joined. We could do so at the present session of Congress.

"There are other considerations which I have not time to discuss.

"It is necessary to arrive at results as soon as possible.

"1. Some important construction we have deferred to await the negotiations.

"2. We shall soon have to decide important questions which would be affected very materially by the junction of our interests. Of course, we are not so improvident as to act now on the hypothesis of successful negotiations between us.

"Our construction is advancing well. We have sent up 400 additional men since Feb. 1. We still strain every nerve for eompletion June 1 . None of our managers in the West fear that it will be much later. I assure you that in this respect and in all respects our affairs were never so promising as now. I express my strong desire to form a junction of our interests as frankly as if you did not represent the other party to the negotiation; for, while attending carefully to everything necessary to our independent existenee, I see that it can still be bettered by the measure contemplated. There is no mistake so common anong business men as to suppose that what one gains another loses. I have just had an illustration of this in making in behalf of the bondholders of the Fort Wayne a counter proposition to that of the stockholders under which the stock rose 40 per cent.

"It is important to all interests that a conclusion be arrived at as soon as possible. When you are in a situation to negotiate definitely, with full powers, I shall be glad to discuss and also to submit suggestions, and shall be ready to conclude arrangements, if any be found practicable.

"Please excuse the rambling haste in which I write.

"I remain,

"Very truly, "Your friend,

"S. J. TrLdex.

"Joseph S. Fay, Esqr., Boston, Mass." 


\section{TILDEX TO JOS. S. FAY}

"New Yonk, April sth, 186'.

"Mr DEAr Sir,- Your letter of the 4th was duly received.

"In reference to your" conchnsion that there is "no difficulty in arranging some mode of sale but price,' I agree that it is justified by the general correspondence of our views as to the utility of uniting the two lines and as to the poliey which should govern the management of the joint concern. Doubtless your mind has truly fixed the precise point at which divergence of sentiments would be natural, and where alone it is likely to exist.

"But is snch divergence inevitable even there? Is there not some solution which will give us what we agree in desiring - the unity of works and interests, and will yet allow scope enough for the favorable view by each party of the relative value of its own property?

"Financial expedients are so capable of adaptation, and I have so often been fortunate in bringing into accord interests and opinions which seemed to the parties to clash, that, seeing an olject desirable to us both obstrueted or delayed, I am disposed at once to analyze the elements of difference, and try if there be not some solution equally adrantageous and equally agreeable to the parties whom we respectively represent.

"I know I shall bring to the attempt candor in considering what I may not at first accept, and an entire freedom from the huekstering spirit which seeks to appropriate all benefits of a concord which ought to be founded upon mutual interests. I do not doubt that you will meet me in the same dispositions.

"I mentioned in my former letter sone of the evils of delay-the loss of the present session of Congress in respect to our land grants (we shonld want Mr. Morwan as our regular attorney to join his efforts to our special and temporary agent if we were together), the tendeney to reduce or keep down the prices for our transportation services, from the natural operation of divided action, to be aggravated perhaps when our agents come to seek husiness, the probability of some mnecessary enstruction.

"You have justly arderl the inenvenience of extending over the region : diversity of ganges, every day becoming more difficult to change. 
"And I now add still another consideration. The delas - perhaps indefinite postponement of the construction of the link from Green Bay to the place, lately Sand Point, which we have christened Escanaba. That construction would connect the mineral regions of Lake Superior with the entire railroad system of the country.

"Now, in these times so favorable to get money for new enterprises, if the opportunity is seized and wiscly uscd, I think if we were united, our joint strength would induce the Northwestern to put in that link this year if the question could be determined within the next 30 days. There are auxiliary influences, potent at this moment, which may be lost and the result postponed for an indefinite period.

"I am confident that such a construction would enlist the warmest sympathies of yourself, of $\mathrm{Mr}$. Ely, and of all who liave investments in the Lake Superior region. It would probably create, likewise, new opportumities for investments, capable of surviving the financial shock to which all property will be subjected by the present condition of the country.

"But I wander into discussions, when the object with which I began my hasty letter was simply to say to you that I think we ought to have a personal conference without unnecessary delay-that we ought to be possessed of the purposes of our respcetive parties, and armed with full powers to act, if not for all, at least for a majority in interest of our respective companies.

"I will meet you in Boston or in this eity at your earliest convenience, having a little notice to arrange my engagements. My situation would make me prefer New York, if your convenience would allow or you could be induced into a visit to your friends here.

$$
\begin{aligned}
& \text { "Very truly, } \\
& \text { "Your Friend, } \\
& \text { "S. J. TILDEN. }
\end{aligned}
$$

"Jos. S. Fay, Esq."

TILDEN TO MR. KENT

“ N. Y., Mar. 26th, 1864.

"My DEAr Sir,-I send some specimens from various locations in Lake Superior country on which I desire information and your judgment.

"No. 1. Hematite is claimed to give $611 / 3$ per cent. 190 
of iron. They call it granular hematite. I should like to know whether it will prodnee so much in order to judge whether it will bear very distant transportation. I should like your judgment of it in all respects.

" 2 and 3 are of the same general character.

"Next. I want to know whether No. 6 has any admixtures which may affect its value in working. It is called specular and slate iron.

"Next. I want to know about No. 4. The analysis given me is 41.855 metallie.

"31. ox iron manganese.

"It is called massive hematite pyrotistic.

"I should like to know about its working character and its availability.

$" 5$, I believe, is similar. 7 and 8 are specimens of slate iron.

"S claims to be 49 per cent.

"T claims to be 57 per cent., with traces of manganese. It feels too light. I should like a test of it.

"I should be glad of your ideas on the subject at as early a day as practicable. Send me results as they can be obtained without waiting to complete all.

"Mr. Kent."

$$
\text { "Truly, }
$$

C. EAMES* TO TILDEN

"Thursday 10th, 1-2 past 11, "Ilay 11), '6'.

"Mr Dear Tilden,-T want youl, as a very great favor to Mrs. Eames and myself, to give me your time from $1 / 2$ past two to-morrow, sharp, at which moment I will be here to take you up to 84 th St. to look at some lots and honses, and see how they ean be divded in four equal or nearly equal parts and values-differences of value to be settled by payment or receipt of money-so that division of same among the co-lieirs may take place by agreement withont the fuss

* Mr. Eames took the first honors of his elass at Harvard University ; studied law in New York; married the eldest daughter of Judge Campbell, then Surrogate of Now York city. On the election of Polk he took up his residenee in Washington, and during the Civil War was mueh cmployed by the government in the Supreme Court, as comsel of the Navy Department, in resisting illegal claims. 
of partition suit. Your help in this will have a great weight of authority with us all and will carry the thing through. Fanny has set her heart upon it. Please do not refuse. I fix day and hour so sharp beeause I must go back to Washington Thursday, and an told not to come till this is done. The brothers will go with us to look at the property.

"Yours very truly,

"Thursday 10th, 1/2 past 11.

"C. Eames.

"May 10\%4."

\section{J. VAN BUREN TO TILDEN}

" 39 Nassau, N. Y., May 20th, 1864.

"Mr dear Tildex,- - h have had no opportunity to inquire about the Kaska William Coal Co. stock, but have such conficlence in rour knowledge and judgment that I will take of you the 200 shares at $\$+250$, and feel obliged by your letting me have them.

"Please let me know when you require the money.

"Take care of your health, and believe me, "Truly y'rs,

"Mr. Tilden." “J. VAN BUREN.

GENERAL J. S. WHITNEY TO TILDEN

"79 State Street,

" Hox. S. J. Tildex.

"Bostox, Sept. 2\%, 1864.

"Dear Sir,-I desire to introduce to your acquaintance my son, the bearer, Mr. William C. Whitney. My son wishes to complete, in your city, his preparation for practice in the law. I have taken the liberty of advising my son to call upon you for the reason that I believe a few words of friendly advice from rourself would be of great value to him in fixing upon his selection of an office for further preparation. Any advice or act of courtesy you may please to extend to my son, I need not say, will ever be regarded as a great personal favor to

"Your. obt. Servt.,

"Jaires S. Whitney."

General James E. Whitney was the father of the late William C. Whitney. At his behest, Governor Tilden was 
instrumental in sceuring for the son, then recently araduated from the Harvard Law School, the appointment of counsel for the corporation of the eity and rounty of New York. 'The son subsequently becanc-through Mr. 'Tilden's aid, I believe-a very large proprietor of stock in the metropolitan railways, and later was a nember of President Cleveland's Calbinet as Secretary of the Navy during that President's first term. He died in 1904.

TILDLN TO S. C. BALDWHN

"NEw York, Nov. 1\%, 1864.

"Mr dwar Sir,-There are so many topies about which I desire to write yon that I must tonch them rapidly.

"1. Yon and Wetmore are eleeted directors of the Iron Cliff. You will be entitled to the information, advice, and aid which Wetmore shall be able to give.

"Yoll must represent the company and act in all eases where it is neeessary.

"2. Information. We need direct and frequent communications with the Cliff Co.

"Mr. Curtis will have more time than the rest, and his oecupations will be more regular. He should write twice a week, giving information as to all matters concerning the operations of the co., the no. of men, the preparations to accommodate them, the work going on, ete.

"From you I should like to hear as often as you are able.

"Communieations should be addressed S. J. Tilden, 12 Wall St., New York City.

"3. Col. Foster left Mr. Ray in charge of the Tilden and Foster mines; Mr. Foote in charge of the Ogden; Mr. Curtis managing the accounts and finances, and $\mathrm{Mr}$. Whitehead conducting explorations; and these gentlemen, all in the main, independent of each other.

"I shall be surprised if disorganization does not develop the want of a head to enforce aceountability and to govern and direct.

"For the time being you must assume and exereise whatever powers seem to be necessary in order to keep harmony hetween all these different authorities, and to see that all are working well.

"Whether we shall need a mining head, independ$19: 3$ 
ently of these gentlemen, is a question upon which, after you have studied them, and the working of the business, I should like your opinion. It may be that a general business head will be all that will be required, and that Mr. Ray and Mr. Foote will get along well in their respective departments. Or it may be that some man like Mr. Merry or Mr. Ferguson will be required.

"Between us, Mr. Merry told me, just before I left, that he wished me to bear in mind that he expected to be with us next year. Mr. Stewart, of the Jackson Co., rather complained to Col. Foster that Mr. Ogden had interfered with them in respect to Merry.

"I mention the state of things that you may be advised of the actual state of the case, and may be considering what information and advice you can give me.

"As to Mr. Curtis - he was engaged by Col. Foster as a sort of cashier when the former was about leaving without our having much knowledge or experience in respect to him. I have been to see Mr. Booth, who recommended him, and get the best accounts as to his trustworthiness.

"Whether we can hereafter enlarge his functions will depend upon how his capacities shall develop in the experience of our business.

"In the mean time he should be required to organize our accounts, take an inventory of all materials and supplies sent up for the use of the company, keep a record of their use, and be able to account for them; open an account with each mine, and enable us to know that all the expenditures of each are proper, keeping a sort of financial supervision over their operations; corresponding with us, and keeping us advised of everything which is going on.

"Col. Foster informs me that he instructed Ray and Foote to send here a report each week of their doings.

"Consult with Mr. Wetmore and give me your views as to

"(1) What is necessary for the sale of ore and the management of transportation at Cleveland or elsewhere; study the organization of the other companies; see whether it is best, etc.

"(2) What will be necessary at Escanaba.

"(3) Whether anything further will be necessary at the mines.

" 5. It will be quite necessary for us to have the branch 194 
to the Cliff mines and the extension to the Cleveland done, and all the road in good rumming order.

"6. It is very lesirable that we have this winter the benefit of a telegraphice eommmication with the Cliff mines.

"It is equally necessary for the Peninsular railroad. And for that - but especially for the Northwestern - a winter road from Escamaba to Green Bay is important.

" 7 . For the Tron Cliff mines see that all necessary supplies are provided; see Ray and Foote on this subject, and have them closely interrogated that nothing may be overlooked; Mr. Merry wonld aid with all his experience in making provisions for winter work, and Mr. Wetmore will also have much information on this subject.

" 8 . In respect to any question requiring experience in working mines, Mr. Merry was good enough to say he would aid Mr. Ray (who is his brother-in-law) and us generally. You can have recourse to him, if necessary.

"9. It is thought that at the Ogden mine (Foote) accommodations ought to be made for at least $50 \mathrm{men}$; and at the Tilken mine for 100 men.

"This is for immediate operations, looking, of course, to enlargement as fast as possible.

"10. I intended to write to you on the subject of furnaces, but must defer that subject to a future oceasion.

"Please adrise me of the condition of the Peninsular R. R., and give me what information you can as to the mines, dock, branches, ete.

"One of the most serious inconveniences attending the construction of the Peninsular-all through-lias been the want of regular information here.

$$
\text { "Truly Yours, }
$$

"S. C. Baldwin, Esq."

Charles P. Daly commeneed his public eareer as a member of the New York State Assembly soon after his admission to the har. From the $\Lambda$ ssembly he was appointed judge of the Court of Common Pleas, which position he continued to hold by re-clection until lo was retired by age. Meantime he had been prominent in founding the New York Geographical Society, of which he was the first and only president until his death. 


\section{LETTERS AND MEMORIALS OF SAMLEL J. TILDEN \\ เ}

TILDEN TO CIIARLES P. DALY, CIIAIRMAN OF COMMITTEE ON

INVITATIONS TO THF MEETING, TO BE HELD IN UNION

SQUARE, TO CELEBRATE RECENT NATIONAL

VICTORIES, ON MARCII 4, 1565

" 2 Union Plade, March 3rd, 1865.

"Gentremen,-Your letter, inviting me to "address the great meeting, to be held at Union Square to-morrow, to celebrate the recent national victories,' reaches me while I am confined by illness, and expect to be, at the time of the meeting, totally disabled from speaking. I shall, however, none the less, join in rendering the most grateful bomage to the achievements of our gallant soldiers and sailors and their skilful commanders, and the most cordial appreciation of the value of these achievements towards preserving the unity of our Federal Republic, and the nationality of the great people which has been formed under the shelter of its rightful and beneficent sway.

"These sentiments have never been weakened, even when it has sometimes seemed to me that this great object of our efforts and sacrifices was imperilled, and those efforts and sacrifices made more costly, if not fruitless, by errors of civil policy or of military or financial administration. Nor, amid such errors, and all errors tolerated during the 'throes and convulsions' of eivil war, by the people, who were in so unaccustomed a situation, and were intensely occupied by the great struggle in which they were involved, have I ever lost faith that, when the struggle should be once successfully over, they would completely re-establish the great traditions of constitutional government, founded on local self-control and on individual liberty and personal rights.

"Let me add that, in the present posture of our public affairs, it is better to look forward than to look behind-to think of battles to be fought rather than of victories already won, and in preparing that wise and liberal statesmanship by which alone a complete pacification of the country is to be attained, to remember that 'peace hath its victories, not less renowned than war.'

"To co-operate, candidly and cordially, with the existing public agents in all measures for bringing the war to a successful close, and to remove the evils it will have engendered in our civil and social systems seems to me as plain a duty 
as it is at erery election to pronote the elowee of such publie agents as will, in our judgment, best attain these ends.

"With much respect, I remain,

$$
\text { "Truly yours, }
$$

PETER W. COOPER AND OTHERS TO TILDEN

$$
\begin{gathered}
\text { " Eigifteentu Ward, } \\
\text { "New Yolse, A pril 3rd, } 1865 .
\end{gathered}
$$

"Denr Sir,-We appeal to your generous kindness and well-known liberality in all publie concerns to aid us in the effort to avoid the necessity of having the draft enforeed in this ward.

" $\Lambda$ number of citizens have contributed to a fund for this purpose, and we venture to hope that you will not withhold rour assistance to save a number of good and nseful eitizens from being taken from their families.

"Please enclose your contribution to either of the undersigned.

$$
\begin{aligned}
& \text { "Pet. W. Cooper, } \\
& \text { "Jaines Kelly, } \\
& \text { "Cilitiles P. Kirkicand." }
\end{aligned}
$$

\section{SAMUEL L. M. BARLOW TO TILDEN}

"New York, Aug. 31, 1865.

"MY Dear Sin,-My friend, Mr. Honston, of Ky., has returned from Washington. I am more satisfied than ever before of the position of the President, but I think ron shonld at once go to Washington and have an interview with him. I enclose Mr. Houston's eard, which will insure an carly meeting after your arrival.

"I am entirely in faror of a hearty and carnest support of the Prest. by our convention, and I hope the tone of the resolutions to be passed will he more moderate than in New Jersey, or Pa. or Ohio. On one subject only is it necessary to be entirely free from ambignity-T mean on the question of the civil rights of the people, North and Sonth, and their right to know that the first fruits of peace, to wit., freedom from the military power, are fully assured.

"I will see you on your return.

$$
\text { "Yours truly, }
$$

“S. J. Tilden, Esq. 
"On one other question I think our convention should act explieitly. I refer to the pledge of the public faith of the gort. to its ereditors, towards whom the highest order of national honor is pledged.

\section{"S. L. M. B."}

\section{F. P. BLAIR TO TILDEN}

“WASH., 19 Oct., 1865.

"Mr dear Tilden,-I have a letter from Frank, written at Cincinnati previously to his speech in St. Louis, in which he refers to you and myself to judge of the circumstances, the when and the how, he shall do what it seems he has declared to the country publicly he is ready to do, if necessary, to advance the cause of the party which nominated him to the Vice-Presidency. If, therefore, any change is to be made in the persons to represent our cause in the Novr. elections, please telegraph and I will come instantly to meet you.

"So much as concerns Frank's position.

"Now let me say a word about the intrigue which produces our difficulties.

"Seward and Chase, who never were identified with the Democracy, have entered into a coalition to control its destiny. They were 'unco-thick and thrang thegither' last winter, and Seward disclosed to an ardent Democrat the other night the cause for which they combined. Seward approached a brother-in-law of Voorhees and made an eloquent appeal to him to convince a company brought together for the purpose that it was necessary that Chase should supplant Seymour, and, of course, that the nominations of our convention should be surrendered. Now it is clear that the Chief Justice and the Secretary of State have undertaken to dispose of our party. Neither ever had its endorsement for any station. Why should they be allowed to dispose of the highest without having consulted the people?

"If we are to change front, why not take MeClellan and Pendleton, who have been endorsed by national convention and the party at the polls? Why not Hancock and Hendricks, who had high rotes in our late convention? Why not MeClellan and Hendricks? Or Hancock and Adams? We might bring Indiana and Penna., or Indiana and Ohio by their most famous Democratic sons to increase the vote of the last election in these States. I think these or many other combinations might be made to strengthen our ticket. 
"In my opinion the copulation of Seward and Chase would bring not only defeat, but eternal disgrace on the Democracy.

"This, however, all for yourself. What I have to say further about the second to Mr. Seymour will be in person and in consonance with your joint wishes.

$$
\begin{aligned}
& \text { "Your af. friend, "F. P. Blair." } \\
& \text { "F. }
\end{aligned}
$$

GENL. DANIEL BUTTERFELD TO $\mathrm{s}$. J. TILDEN AND OTHERS TESTIMONIAL TO GENERAL ULYSSES S. GRANT

"New Yonk, Feb. 19th, 1866.

"Drar Sir,-I have the pleasure to enelose you (fac simile) copy of Lt.-Genl. Grant's acknowledgment of the testimonial to which you were a contributor; also a list of the subscriptions and copy of the correspondence.

"In furnishing this information to contributors I am requested to ask that no copy of these documents may be allowed to be printed, as many subscriptions were made with that understanding. Please consider this my receipt for your subscription.

$$
\begin{aligned}
& \text { "I am, very resp'y, } \\
& \text { "Yours, \&c., } \\
& \text { "DANL. Butterfield. }
\end{aligned}
$$

"Please acknowledge."

"New York, Feb. $15 t h, 1866$.

"Lit.-Gent. U. S. Grixt, \&e., \&c., \&e.

"Gexerat,-In accordance with the request of many citizens of New York, whose names are herewith transmitted, I have the honor to ask your acceptance of the enclosed testimonial of their appreciation of your services.

$$
\begin{aligned}
& \text { "I am, very resp'y, } \\
& \text { "Your obt. servt., } \\
& \text { "Dinl. Bu'tererfield. }
\end{aligned}
$$

"Fnclosed find:

" Mortatage and interest.. . . . . . . . \$30,487.50

$5,0,0007.30 \mathrm{~s}$ U. S. 1st series......... $54,725.00$

Cash ................ 19,587.50 


\title{
LETTERS ANI) MEMORIALS OF SAMLEL J. TILDEN
}

\author{
TESTIMONIAL TO LIEUT.-GENI., U. S. GRANT
}

\section{LIST OF SUBSCRIPTIONS}

N. Y. Stock Exchange, by R. L. Cutting, Prest... \$5,000 Aspinwall, W. H......... Astor, W. B............. Brown. Jas............. Barney, D. N.......... Bonner, Robt............. Chittenden, S. B........ Claflin, H. B. \& Co....... Clens, Kenny.......... Coming, H. K............ Culver, C. V........... Cutting, F. B........... Davis, Chas. Aug........ Dinsmore. W. B.......... Drew, Daniel........... Dunean, Sherman \& Co.... Eno, $A \operatorname{mos} R$.......... Fearing. Danl. B........ Forbes, Paul S.........

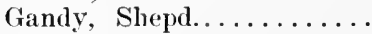
Garrison, C. K......... Green, John C........... Grinell, Minturn \& Co.... Griswold, N. L. \& G...... Harbecks \& Co.......... Holliday, Ben........... Howland \& Aspinwall.... Hunt, Tillinghast \& Co.... Johnston, John T........ Johnston, J. Boorman..... Lanier, J. F. D..........

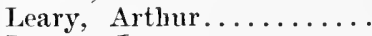
Lenox, Jas............

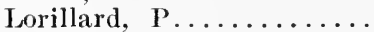
Low, A. A. \& Bro......... Matthews, El........... Morgan, E. D. \& Co...... Ogden, Wm. B........... Opdyke, Geo. \& Co........

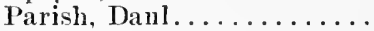
Phelps, Dodge \& Co...... Roberts, M. O......... Sampson, Joseph......... Spofford, Tileston \& Co... Stewart, A. T........... Stuart, R. I. \& A........ Taylor, Moses............ Tilden, S. J. ............. IVetmore, Saml.......... Weston \& Gray........... Wheeler, Sam. G........ Wolfe, Jno. D..........

\section{1,000}

1,000

1,000

1,000

1,000

1,000

1,000

1,000

1,000

1,000

1,000

1,000

I,000

1,000

1,000

1,000

1,000

1,000

1,000

1,000

1,000

1,000

1,000

1,000

1,000

1,000

1,000

1,000

1,000

1,000

1,000

1,000

1.000

1,000

1,000

1,000

1,000

1,000

1,000

1,000

1,000

1,000

1,000

1,000

1,000

1,000

1,000

1,000

1,000

1,000

1,000
Carricd

Allen, D. B......... 500

Andrews, Loring......... 500

Anthony \& Hall........ 500

American Express Co...... 500

Arnold, Constable \& Co... 500

Armstrong, M. \& Sons..... 500

Ashley, O. D.......... 500

Babeock Bros. \& Co....... 500

Ball, Black \& Co........ $\quad 500$

Banker, Jas. H. ........ 500

Barker, H. J. \& Bro..... 500

Beekman, J. IV ......... 500

Bronson, Fredk......... 500

Brooks, D. H. . . . . . . 500

Cary \& Co........... 500

Cash ............... 500

Collins, Geo. C......... 500

Connolly C. M........ 500

Cowdin. E. C.......... 500

Cutting, R. L.......... 500

Dabney. Morgan \& Co...., 500

Delmonieo, L.......... 500

Dows, David........... 500

Detmold, C. E......... 500

Easton \& Compy........ 500

Englis, J. \& Son ......... 500

Field, B. H.......... 500

Garland, Jno. R........ 500

Goodridge. Fred.......... 500

Grant, O. D. F.......... 500

Greenleaf, Norris \& Co... 500

Griswold, A. W........ 500

Groesbeck, D. \& Co...... 500

Haggerty, $0 \ldots \ldots \ldots \ldots \ldots . . \ldots 0$

Hanna, Saml. .......... 500

Howe, S. C. \& Co......... 500

Hoyt Bros........... 500

Hoyt. Edwin.......... 500

Hurlbut, H. A........ 500

Kennedy, R. Lenox....... 500

Lane, Fredk. A........ 500

Lang, IV. Bailey \& Co..... 500

Learned, Ed........... 500

Livingston, Fox \& Co..... 500

Lord, liufus L.......... 500

Mali, H. IV. T....... 500

Marshall. C. H. \& Co..... 500

Mever, S. H........... 500

Mitehell. Saml. L....... 500

Morton. T. P. \& Co...... 500

Phelps, I. X........ 500

Phelps, J. J......... 500 


\section{LETTERS AND MEMORIALS' OF SAMUEL J. TILDEN}

Carricd formard.....\$\$2,000

P'lace, J. K. \& E. B...... 500

Polhamus. 'T. \& Co.......

Quintard \& Everett......

Quintard, Sawyer \& Warl. .

Randolph, F. F.........

Robbins, G. S. \& Son......

Roosevelt \& Sons.........

Russell, C. H...........

Sehmehardt, F..........

Selover, A. A...........

Shultz, Jackson S.......

Skinner, F. \& Co.........

Slade \& Colby............

Steward, Joln...........

Stewart, J. \& J.........

Stimson, H. C. \& Co......

Sturgis, Jonatlan........

Thompson, Sam. C.......

Tiflany \& Co............

Traveis, W. R. \& Co.......

Trevor \& Colgate.........

Tuckerman, J. \& L.......

Ward \& Co............

Webb, Wn. II..........

Williams \& Guion........

Winslow, J. F........ 500

Forward
500

500

500 1)raper. Simeon..........

500 Draper, J. H. \& Co.......

500 Gentil \& Phipps.........

500 Halsted, Haines \& Co.....

500 Janses, F. P...........

500 Jesup, М. K...........

500 Lottimer, Wm.........

500 Morgan, H. F...........

500 Packer, E. A..........

500 Peckham, IV. H. . . . . . .

500 Slierman, Isaac..........

500 Skeel \& Reynolds........

500 Skiddy, Francis.........

500 Taylor, R. L. . . . . . . . .

500 Wesley, E. B..........

500 Talman, Geo. F.........

500 Ward, G. Cabot..........

500 Bentley, N. S..........

500. Chapmin, T. G. . . . . .

500 King, T. G. \& Sons........

500 Lockwood \& Co..........

500 Sehuyler, Hartly \& Graham

500 Whiteright, IV..........

Total
$. \$ 101,000^{*}$

" Head Quarters Armes of tile United States.

“ Washington, D. C., F'eb. 17, 1866.

"Dear General,-Your letter of the 15th inst., enclosing me the very handsome testimonial of the eitizens of New York, with names of all the too generous contributors to it, is received. I feel at a loss to know how to express my appreciation of this substantial token of the friendship of the citizens named in your letter, and for the generosity of the eitizens of New York generally, and especially towards those who they conecive have rendered service in maintaining the integrity of the whole Union. Suffice it to say that I shall always appreciate their generosity towards me and endeavor to pursue a course through life, and to make snch use of the means thus mexpectedly placed in my possession, as will meet with their apploval.

"Throngh you I wish to thank the gentlemen whose names you have enclosed to me individually and collectively.

"I have the honor to be, Your obt. Servt.,

$$
\text { "U. S. Grint, Lt. Gen." }
$$

* The diflerence in the amounts received by General Grant and the amounts subseribed was doubtless cash from the donors whose names were withheld. 


\section{J. D. VAN BUREN TO TILDEN}

"SO4 BR'WAY.

"Denr Sir,-I am, in one sense, not a politician, and my opinion is not worth so much as those of others; but in the sense of being always interested in public affairs, I am perhaps a politician. What I mean is, that I have not a view of things from inside of the machinery.

"From the outside I have naturally thought about candidates for Governor. I have come to the conclusion that you are the best man for the place. I take it for granted you have no desire for the place, for I am willing to judge you as favorably as I would judge myself, and such a place would have no temptations for me.

"But at this time you have no right to consider only your own convenience.

"You are the best man-

"1. Because you would poll more votes than any other (Dix included); you are above the rings and cliques, and would excite no personal antagonisms.

"2. Because you conld, after election, make a party of the right materials. The only set of men who can bring back our polities to purity and statesmanship are the Barnburners of this State; after carrying the election these men, whether they have voted of late years the Democratic or Republican ticket, could, under you, be brought togetherconld make a new Democratic party, slough off the corrupt elements, especially that malign influence with which we shall have to act this election, T. IV., and dictate a reform in the Cabinet which should give the influence of the general govermment to the same sound principles as of old controlled this State. This, I think, is the great movement to be made in politics - the reconstruction into compact force of the divided Barnburners, and for this we must carry this State election first, no matter what allies we have to take in for the present.

"I, of course, shall not mention your name for the place to any one, but, if it should be offered you, you must not decline. Stranger things have happened than that it should be offered amid the conflicting claims.

"Yours respectfully,

"JNo. D. VAN BURen.

"S. J. Tilden, Esq." 


\section{TO DE DESTLOYLD}

"My desl: Su,-If rou should decide on talking with our venerable father of the faithful fully, I thomght it might be well you had an excuse for doing so in a suggestion from some one, no matter whom. To that end yon may use the enclosed if worth using.

$$
\text { " Y'rs, " J. D. V. B." }
$$

\section{TILDEN TO HUGH MCCULLOCII}

\section{"Confidential.}

"Hon. Mígin McClllocil,

"New York, Sep. 1\%, 1866 .

\section{"Secretary of the Treasury,} "Washingtoll, D). (C.

" MY DEur Sir,-There is a rumor hore that some changes in the Ferteral appointments for this city are being projected. My object in writing you this morning, in too mucl haste to allow of any discussion, is to say that before anything of this character is done those who represent the mass of President Johnson's supporters in this State, in an anthentic and authoritative form, wish an opportunity of submitting their views to him.

"It is important, in the last degree, that in any changes which are made in the great appointments here, and, indeed, in any of them, the influcnee which these offices are capable of exereising shonld be held and exerted as a sacred trust for the success of the administration and the policy of President Johnson.

"T'o give them away as mere personal benefactions-to allow them to beeome the mere aids to ambition or interest of a selfish individual or clique, to be disposed of by him or it als nere patronage or for peemiary gain-wonld be suicide on the part of the President and a betrayal of his supporters and his cause.

"In the course of a week or ten days I slaall have the pleasure to see your and to discuss these matters.

"In the mean time, please do ne the farol to communicate to the President the request eontained in this note, and let it remain strictly confidential between you and him.

"Yon will notice that the T'imes of this morning staggers a little. The real diffienlty is that it is cosing subscribers. 
- Up to the time of Mr. Richmond's death the arrangement for the State nominations was that the Democrats should take the Governor and the Republicans the Lieut. Governor. The only chance that Dix had was in a movement which was originated by me. It was contingent on events which could not be controlled, and on the failure of which it was only to be persisted in under circumstances which conld not be prudently defied. But enough till I see you. Let us be firm and comageons and go forward.

$$
\begin{gathered}
\text { "Truly Yours, "S. J. Tiluden." } \\
\text { "S }
\end{gathered}
$$

"Private.

"Hon. Siml. J. Tildin.

S. E. CHURCH TO TILDEN

"Mr dear Sir,-I went from Albany to Chautanqua Co., and did not get your telegram until late Saturday nightnot in time to answer. It is impossible for me to go to New York. I am obliged to go to Albany to-night on business, and then hurry back to the Lockport circuit. On many accounts I would be glad to go to New York, but there will be many better speakers there than I am.

"I hope the committee will make you chn., and I have said so to everybody I have seen. I regard it very important that it should be so, although some of our friends think it should not be in N. Y.; but these men don't know that you belong to the party in the State, and not in the city.

"Now for the campaign. To be successful it must be effective; not merely noisy, but a hard-working campaign, and you will excuse a few practical suggestions.

"1st. A large amount of money must be raised, which, if properly laicl out, will help very much. I think every county should have $\$ 1000$, in two instalments- $\$ 500$ to take a thorongh canvass; this ean only be done by hiring men in each town to do it. We have not had a canvass worth anything in many years, and an incorrect canvass is worse than none. The only way to do it is to appoint a reliable man in each judicial district to visit each co. and put the moner and canrass books in the hands of a reliable man, who will hire and pay the men to take the canvass. It can be done in no other way.

"Then, during the week before the election, $\$ 500$ more to be paid in getting the rotes to the polls. 
"2. A thorough and systematic course of meetings in ewery co.

"Such a campaign, carried on by the State com., with what our friends will do in each co., will earry the State. Anything short of this will result in defeat, in my judgment.

"The ntmost care must be exercised to have the money properly expended. In most of the counties in the State we have no local officer to help ns, and no canvass ean be obtained exeept in the way I indicate-by paying men by the day for doing it.

"Confidentially. Cannot the pressure be made for the Collectorship before election? I suggest it only for your consideration. I shall be happy to hear from you.

$$
\text { "Truly Yours, }
$$

"S. E. Cinurch.

"You ought to go to Washington with Hoffman."

"Private.

"Hox. Sanit. J. Tilmen.

\section{S. E. CIIURCII TO TILDEN}

"DEAR Sir,-It is said that S. P. Allen will be removed from the office of Revenue Collector for this district on charges. He cannot and ought not to be moved on political grounds, beeause he is with us, although not very efficient.

"Put if he is removed we want Wn. C. Rowley, Esq., of this city, appointed without fail, and I will regard it a personal favor if you will interest yourself in his behalf. He is the most useful and efficient party man we have; is honest, and always right. He is a prominent Demoerat, has been several years on the State conn., and was a delegate to the Phila. convention. He is, besides, a friend of mine, and I desire to render hin all the assistance in my power.

"With your" aid, I have no doubt, he ean get the appt. if Allen is remored, and I assure yon it will be in all respects a great political point to aceomplish it.

$$
\begin{aligned}
& \text { "Truly Yours, } \\
& \text { "S. E. Church." }
\end{aligned}
$$

\section{MICCULLOCH TO TILDEN}

"Private.

"Treasury Departient, " Oct. 22, 1866.

" My dear Sir,-Your note introducing Messrs. Magone and Pierce has been presented to me. 
"We are in receipt of communications from reliable fricnds from many sections of New York expressing the opinion that remorals made so soon before the election are, as a general thing, inexpedient, and may do injury to the cause. The President feels, therefore, that, in making changes, the greatest eare should be exercised. He desires to meet the wishes of his friends, but he desires, also, that his friends should be fully and thoroughly advised before they endorse applications for changes.

"It has occurred to me that a change of Collector in the St. Lawrence district at the present time would be injudicions; and while we desire to take care of Gen. Barney, we are of the opinion that it would not be advisable to appoint him Collector just now, certain as it is that his nomination will be rejected by the Senate.

"I am, very truly, Yours, "H. McCulloci, "Secretary.

"Hon. S. J. Tilden, New York."

\section{H. MCCULLOCH TO TILDEN}

"Private.

"Treasury Department, Oct. 26, 1866.

"Dear Sir,-Your two favors of the 22nd inst. are received.

"Campbell's appointment was suspended because we were advised that the incumbent was ill and a conservative; that, while absent for the benefit of his health, the office is being administered by the deputy, who is a hearty supporter of the President. Under the circumstanees of the case it was thought best by some of our judicious friends that no change should take place in the office; at all events, until after the election.

"The decision of the President to withhold from Mr. Campbell his commission was not influenced by the representation of any gentlemen unfriendly to Mr. Campbell or his brother, the candidate for Congress, but rather from a desire to do nothing which might impair the administration's strength in the district. After the election the subject will receive due consideration.

"In regard to the 12 th district, I have only to say that a good deal of disapprobation has been expressed by the ap206 
pointment of Mackin as assessor; and as there seemed to be a good deal of difference of opinion among our friends in the district in regard to the removal of the collector, it was thought advisable to make no change in that office for the present.

"It is pretty elear to my mind that in order that an office shonld be made effective in an election, it is important that the office should be fully and properly organized some time in advance.

"The President desires to make as few changes as possible, and none on political grounds nuless it is clear that the interests of the service or the interests of the administration are to be ecrtainly benefited by them. I will, however, present this case again to the President.

$$
\begin{aligned}
& \text { "I am, very truly, Yours, } \\
& \text { "H. MoCuluocir, } \\
& \text { "Secretary. }
\end{aligned}
$$

"Hon. S. J. Tilden, New York.

"I return Mr. Campbell's letter."

TILDEN TO MAJ.-GEN. JOHN A. DIX

"New York, Nov. 20th, 1866.

"Maj.-Gex. Join A. Dix.

"Denr Sir,-As you are about to leave our country for the distinguished post in the diplomatic service to which you have been assigned by the govermment, we avail ourselves of the occasion to express to you the respect and esteem which we entertain for your personal and public eharacter, and invite you to partake with us a private dimer at the Union Club at such tine as you may conveniently designate.

"With much respect,

$$
\begin{aligned}
& \text { "We remain, very truly, } \\
& \text { "Your friend, } \\
& \text { "6 }
\end{aligned}
$$

"New York, Nov. 20th, 1866."

S. E. CIIURCII To S. J. T.

"Private.

"Mox. Sinil. J. Tilden.

"Rociester, March 8, '67.

"Mr pear Sir,-Would it not be a good idea to publish a quantity of the veto message of the military bill for general 207 
circulation? There might be other things put with it and make a doemment and eirenlate it throngh the committees. I think it would do far more good now than during a campaign.

"This measure seems to me so momentous in every aspeet of it that I cannot keep quiet. If we eannot do anything else, let us howl. Our papers do not make as much noise as they ought to about it. The World is the most outspoken, and it should keep it up; but the most effective work would be the circulation of the veto message, with a brief history of reconstruction since the war closed.

"Johnson talks and writes well, but he lacks executive pluck. He shd. have forced Congress to let the South in at the start, but he failed, and it is now too late.

"He now trembles for fear of impeachment, and will in the end give the radicals all the offices in hopes thereby to propitiate them and prevent impeachment. But they will impeach him and despise him, besides, for yielding, and before another year rolls around Ben Wade will oceupy his place. They know that he is cowardly and will not fight, and they will for that reason go to the extreme.

"I know that you are averse to a row. So we all are, but I tell you there is no other way. It must eome sooner or later; these devils are bent on destruction, and the sooner the crisis eomes the better for us, because they are strengthening themselves every day.

"There is only one chance left, and that is when the impeachment comes for the President to refuse to yield the office in the first place, and in the second place to refuse to be tried by part of a court. He ought to refuse to carry out the military bill, and let the fight commence now.

"Please write me.

$$
\begin{aligned}
& \text { "Yours truly, } \\
& \text { " S. E. Church. }
\end{aligned}
$$

"P. S.-The dist. atty. matter is not yet disposed of. It would be a disgrace to reappoint Dart, and I hope they won't do it."

TILDEN MADE AN LL.D.

“ University of the City of New York, 17 May, '6\%.

"Samuel J. Tilden, Esq.

"Dear Sir,-It gives me pleasure to inform you officially that at a meeting of the council, held last evening, the degree $20 \mathrm{~s}$ 
of Doctor of Laves was conferred on you by their manimons vote, and the same will be announced at the coming commeneement.

"With great respect,

$$
\begin{aligned}
& \text { "I am, Yours, \&e., } \\
& \text { "Isinc Ferris, } \\
& \text { "Chancellor." }
\end{aligned}
$$

JOHN A. DIX 'TO TILDEN

ANTI-RENTERS AND THEIR-LEASES

"Paris, 19 June, $186 \%$.

"MY DEAR Sir,-I wrote you some two months ago, but have not heard whether you received my letter. I expressed the hope that you would be a nember of the constitutional eonvention, and was very glad to see that you were ehosen.

"I presume the anti-renter's will endeavor to get some amendunent of the Constitution, by which they may become owners of the fee of the lands they hold under leases without eompensation. This, if done direetly, would inpair the obligation of contracts, and would be declared void by the Supreme Court of the U. S. It will, therefore, probably be attempted indirectly-by burdening leased lands with disabilities and exactions, which will make them of little or no ralue to landlords.

"In regard to leases forever, it is possible that there may be a proposition to convert them into allodial tenures by giving to lessees the right to redeem them by paying to the lessors a principal sum, which will yield the rent in the anmul interest. This would be to introduce a condition not in the contract. I would not object to it on any other ground if the sum paid were sufficient to yield the rent at an interest of four per cent., which is considered a fair rate on agrienltural lands. For instanee, if the anmual rent on a farm or lot leaser forever were $\$ 70$, the principal sum to be paid should be $\$ 1750$. If only $\$ 1000$ were paicl-a principal sum, which at legal rate ( 7 pr. et.) interest yields the rent -the landlord would be put to the trouble of reinvesting on less durable and safe security.

"In regard to leases for years or for lives, the eonvention should not interfere. It may, if it eloose, deelare that hereafter no leases for lives shall be given. The Constitution has already declared that there sliall be no leases of agri209 
cultural lands for more than twelve years; and this is a barl restriction for tenants. But leases for lives are in the process of rapid extinction, and they are not renewed now. $\mathrm{My}_{\mathrm{y}}$ father-in-law, Mr. Morgan, gave a large number of snch leases sixty vears ago. Some of them are still in existence, althongh they were only for three lives, which in England are cousidered equivalent to 21 years. We are selling on liberal terms to the lessees or their representatives. There should be no interference with such tenures, unless it be to prohibit them in future. Every man on Mr. Morgan's land who has used it in a farmer-like manner has grown rich. Only the idle or improvident, and now and then an unlueky fellow, have failed to make money. The lands were leased for the interest of less than $\$ 3$ per acre. They have for thirty or forty years been worth treble and quadruple that price, and the tenants have reaped all the benefit of the advance. Now to interfere in any way with the reversionary interest of the lessor would be the grossest injustice to him. Of course it would be a violation of the eontract, which we should resist; and it would do an incalenlable injury to a commereial State like New York, whose vitality depends so much on the inviolability of its faith and the security of property of all kinds.

"Should there be any movement of the kind I have adverted to, I wish you would talk with Evarts, Pierrepont, and others of the right-thinking men of the convention; and if you please, show them this letter.

"I am very hard pressed between the exposition, the foreign sovereigns, and our own home sovereigns, of whom we have a tremendous influx, and write you 'currente calamo,' as you see.

"We are all well, and cast longing eyes every day across the Atlantic.

"Hon. Saml. J. Tilden."

$$
\text { "Ever Sincerely Yours, }
$$

\section{WILLIAM CASSIDY TO TILDEN}

“14 Augt., '67.

"TIon. Samula .T. Tildinn.

"Denr Thlden,-Your long absenee gives anxiety to your" friends here. We miss you in council and on the floor. You 
must eome up soon; for we will have to meet the financial question, and want you. I would have writen you before, but have been laid up by the heels myself for a fortuight. Indeed, I would have gone down to New York to see you if I had been able. I wonld have asked leave of absenee, but each day you were expected to be on hand, and I am opposed to placing on record the fact that you were ever ill. $\Lambda$ majority of the convention has been on the sick list. Take 160 middle-aged men, and you will have a pretty large show of invalids in midsummer, when all elasses are accustomed to vacation.

"You have lost nothing thus far. We have lost your speceh on naturalization, ete. It must come in elsewhere. Write me, and tell me what I can do to aid you, and when you expect to be on board.

$$
\begin{aligned}
& \text { "Yours truly, } \\
& \text { "William Cassidy." }
\end{aligned}
$$

\section{ANDREW JOIINSON TO TILDEN}

“Executine Mansion, Wasinnton, D. C., Novr. 12, 1867.

"Sir,- - It having been suggested to me by political friends in New York that you have some suggestions which you desire to make to me, in relation to the public welfare, which would be of service to the country, I would be pleased to have your views at such time as may suit your own conrenience.

"Mon. Samuel J. Tilden, New York."

$$
\text { "Very truly, }
$$

\section{HORATIO SEYMOUR TO TILDEN}

"Utrca, Nov. 29, $186 \%$.

"Dear Sir,-I send you the enclosed letter because I said I would call your attention to the sulject of a paper in Kansas. I hope the hammless compliment to me will not harm the writer. Such things are usually found in letters asking favors. I do not know what can be done in such eases. I know that you as well as I have to meet such ealls every day of the week. T hurried up my letter, getting my name off of the list of candidates so that I might save what little property I have. If it is so ruinous to be talked of for nomi- 
nation, I do not see how any one can live through a canvass after a nomination. I expect now to be let alone.

"I wish the State Committee would do one thing-that is, send a circular to any Democratic paper in the State asking them to print John Q. Adams' speech, which is published in Friday's World. The National Committee should see to its publication elsewhere. To my mind it is the most effective speech made in years. This will cost nothing, but it will tell at this time.

"Please to send me back Mrs. Moore's letter.

"Truly yours, \&c.,

"Hon. S. J. Tilden.

Horatio Seymour."

JNO. D. VAN BUREN TO TILDEN

(ENCLOSING MR. VAN BUREN'S CHECK FOR \$200)

"Private.

"New York, Dec. 3, $186 \%$.

"Mr denr Sir,-Take a cool, philosophical view of this note, but believe every word of it.

"It is very hard for me to do an ungracious thing, and few things are more ungracious than to reject kindness. I have carried the enclosed in my pocket a good while, but could not muster courage, when I saw you repeatedly, to take away from you the pleasure of having done the kindness.

"No matter tho' none but you and I know it, I camnot go to the club while $I$ feel that I have not paid my own footing; I have given it a good thinking, and I am sure I shall never incline to go there until this is done. So that the very object you desire would not be attained. You must, therefore, of necessity, take it back.

"It is not becanse I an mwilling to receive kindness from you that I return it; and pray do not forget that the balance of favors done is very largely to your credit as between us. You would have made me Comptroller if I had not refused; and your intentions with me are just as much a cause of gratitude as the realization would have been.

"One other thing. I will continue to give you my aid in the State Committee business, and follow your orders promptly so long as I have time; but for such work I cannot take pay.

"S. J. Tilden, Esq. .

"Yours truly, 
WIILIAT CASSHIY TO TILDEN

“'he 'Argus,' Albaxy, í Decr, $186 \%$.

"Dear 'Tilnex,-The convention is going on, after a fashion, with the jndiciary; New York is absent, except Daly, who has confessed judgment for the judicial partnership in New York, upon which execution is to issue and the corrupt concern to be elosed. Opdyke is ready to adjourn if there is Democratic strength enough to accomplish it. Let the New York delegates be on hand on Tnesday and Wednesday, and we can accomplish it; either adjourn till spring or to New York, for a winter month. Do you notify the eity members confidentially to be on hand. I will write also.

"Schev, according to Warren's account, is not to blame for the protested draft. TIe spent $\$ 1000$, and it was arranged in State committee that I was to go to the 8 th dist. You need not come up to abolish him!

"Scymour is here, and is most anxious to commence the propaganda of Democracy, in tracts and newspapers, under the auspices of the State committee. Yon are murell. Give up railroads and take to polities exclusively. The alternative will be as good as rest.

"Yours ever,

"William Cassidy."

\section{WILLIAM CASSIDY TO TILDEN}

“'The 'Argus,' Albaxy, 12 Dcer., $186 \%$.

"Dear Tildex,-I received your elicek for $\$ 500$, which was welcome, because we were hard up for money at this Argus office. The convention will owe us some $\$ 10,000$, but we must wait for the Legislature and the Camphells to pay us in the spring. For the same reason, if you have not placed the $\$ 3000$ belonging to Mrs. C., I will take it. She can pay part of it on the house she bought, and then I want to buy in Richmond's shares in the Argus. I onght to have them at half price, in view of a certain indebtedness of the late chn. of a State eommittee.

"We will adjourn the convention till spring, in spite of you. Unless the weather is too eold $\mathrm{T}$ will be down to New York. I want to talk of the Presidency, the Cabinet, the Governorship, and of yourself first and last.

$$
\begin{aligned}
& \text { "Yours ever, } \\
& \text { "Wilimal Cassidy." }
\end{aligned}
$$




\section{LETTERS AND MEMORIALS OF SAMUEI, J. TILDEN}

IIORATIO SEYMOUR TO TILDEN

A POLITICAL FORECAST

"UTiCA, Dec. 13, $186 \%$.

" $\mathrm{MT}_{\mathrm{Y}}$ DEAR SrR,-This is a bitter cold morning, and I have made up my mind to keep by the bright wood fire which is blazing on the hearthstone in my farm-house. I shall make use of the time to write to you a political letter. It is seven years since the Democratic party went out of power. Seven years of war or of discord, of corruption, of hate, of taxation and tyranny. In that time, how many who have enjoyed the honors and profit given to them by the Democratic party have turned against it and have proved to be its bitterest foes! How few were left to stand up against the storms of insult, scorn, and threats which beat upon any man who cared for principles of liberty, humanity, and rights! But there were those who did this, and they live to see the day dawning when right and truth will conquer.

"But all conditions have their dangers. The time-servers and spoil-hunters are seeking to come back to our party, not as penitents, but as leaders. They may in time forgire us for not joining in their treachery, but it will always be counted against us that we did not go out with them to gather spoils. There is danger that these men may divide those who stood together in the years of trial and of trouble. They hatch schemes to draw off some who have strength, and thus break up the band that held together in the dark days.

"What should we do to counteract these plans? We have in New York a great party. It is fresh, vigorous, and united. It is animated by a sense of past wrongs and of future victories. We have but a few leaders, for none but men of nerve and of truth could stand the tests of the last seven years. Those leading men are well placed in different parts of the State, so that neither their numbers nor positions make them clash. All fair and honorable ambitions can be gratified-could we be more fortunately organized. Let us in a generous spirit train up as many new men as we can and fit them for places of honor and trust, but do not suffer those who come in sunshine and leave us in storms to walk into our councils and shape our policy with a view to their own gain. We who have held to the canse of constitutional liberty have not always agreed in our viervs. At times there may have been irritation. But surely past trials have made 
a groundwork of an attachment and confidence which cannot be felt towards those who turned against us or who shrank away in our times of trouble. Those generals without troops who want to come back into leadership will bring no strength, but much discord. To my mind it is elear that poliey and duty alike demand that we should stand, as to organization and counsellors, where we are. We do not want more leaders. We have the public with us. But something must be done to let all of our friends feel that we are to act together in the spirit that should be, and I think has been, nurtured in trials we have passed through. We must have the whole matter frankly talked over. In the mean while each one should keep clear of all entanglements. I have written to Sandford E. Chureh on this subject in the way I write to you. I wish you would let me know your views. I think eight or ten men should meet at Albany as soon as the Legislature gets under way. Yon should see four or five in New York-say, Sweeny, Tweed, Brennan, Hoffman, etc., ete. The rival eandidates for the Presideney will all try to get men drawn into their interests. Let us keep our power by holding ourselves free.

"Truly yours, \&c.,

"Horatio Seymour."

WM. A. WALLACE TO TILDEN

"Clearfield, Penna.

"Hon. S. J. Tilden.

" 30 Decr., 1868.

"De.sR Srr,-I have yours of 24 th inst. I have received responses from several gentlemen to whom I addressed letters similar to that to which you reply, and I have been awaiting your reply before proceeding to name a time and place for our meeting. I am still of opinion that good will result from a meeting of the chairmen of the executive committees of the Northern and border States, by securing unanimity of sentiments or discovering the points of difference, as well as from discussing the general plan of eampaign. I have thought of suggesting Washington as the place of meeting, and alout Febry. 1st as the time. If the time and place suit you, and you will so advise me, $\mathrm{I}$ will proeced to notify the ehairmen of all of the Democratic committees and invite their attendance.

"Very respy. y's.,

"WMr. A. WaLlace." 


\title{
LETTERS AND MENIORIALS OF SAMUEL J. TILDEN
}

\author{
$1868-1871$
}

S. L. M. BARIOW TO TILDEN

OBJECTIONS TO IIENDRICKS AS A PRESIDENTIAL CANDIDATE "Private.

" 1868.

"Mr dear Mr. Tilden,-Unless Indiana breaks from Pendleton, as I told you last evg., he will have all the Sonthern votes, including Temessee, this morning, and then Indiana cannot leave him, and he will be nominated.

"I hear that in no case will more than half of the Indiana vote be given for Hendricks. If this is so, it seems to me that a better selection can be made. It is awkward to put a candidate in nomination who gets no vote out of his own State, and in leaving him to go for one who has but half his own State. But you know better about the facts than I, and I may be misinformed as to Indiana's probable course.

"But in no ease is it probable that Hendricks ean be nominated, and for suceess he should not be.

"Wednesday."

$$
\text { "S. L. M. Barlow. }
$$

\section{CLARKSON N. POTTER TO S. J. TILDEN}

"Thursday, 10 A. .r. [1868.]

"MY dear Sir,-At this juncture is it not wise for the N. Y. delegation to ask the Pendleton men whom they will support? If they answer Seymour, he must not decline. But I am confident it won't do to take up Gov. Chase until the Pendleton men have been consulted.

"Faithfully yours, "Clarkson N. Potter.

GOVERNOR WM. BIGLER, OF PENNSYLNANIA, TO TILDEN

"Clearfield, Pa., Feb. 3d, 1868.

"My deAr Sir,-The time is rapidly approaching when we must select a candidate for the Presidency, and so far as the State is concerned we are all at sea. The judgment of our political friends scems to be in favor of the nomination of Gov. H. Seymour, and unless some objection be presented to him of which we have not heretofore heard I think our 
State will declare for him on the 20th proximo. We regard his declination as simply a manifestation of his personal desires on the subject, and not as denying his name and services to the comitry; at all events, we deny his right to control his friends to that extent, and unless his home friends deen it inexpedient we shall mige his nomination.

"I do mot regaud his chances of suceess as in the least impaired by what has occurred in the West. Mr. Pendleton is a good nian, of high attaimments, but I. fear he has started an issue on which we camnot mite; at all events, it eannot be made the leading issue. The restoration of the ten absent States to the Union, with the rights and privileges of the other States, and with their local governments in the hands of their white population, must be the absorbing question. All else nust be suburdinate and secondary. The Democratic party will protect the good faith and bonor of the nation as well in reference to the public debt as in reference to all other questions.

"What is the prevailing sentiment in your State? Is it in faror of Gov. Seymomr; if not, to whom does it tend? Gen. Haneock would do right well for the seeond place, but I do not think our people are inclined to go for him for the first.

"Be kind enough to reply to this note, and address me at the Nerehants IIotel, Phila. What you have to say shall be strietly confidential, and I shall go over to see you if you desire nue so to do.

$$
\text { "Very truly, Your Obt., "WM. Biglen." }
$$

\section{O'CONOR TO TILDEN}

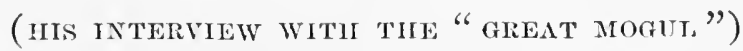

"F'cb. 10, 1868.

"Drar Sur,-T saw the Great Mogul, a arecably to your suggestion, and, funding him in rery good humor, haul a pretty lone, full, and free chat with him.

"IIC is all for the cause, and cares not for any man living relatively to the result itself. He deems a failure framght with indescribable misery.

"I am sure that be speaks the truth and is honest. He

* James Gordon Bennett, Senior, the founder of the New York Herald. 
repeated that so far from having any antipathy against your man, he rather likes him; used some strong terms of commendation, and says that unless by some slip nothing will appear to his personal disadvantage. Indeed, he seemed to agree to my hint that he might best aroid sneering at any one who was a favorite with any so as to keep all in good liumor. He would like very well to get your man in. The whole question is, Who's most likely to win?

"He is in trouble about the feud in Ohio; thinks Vallandigham more of a man than Pendleton. Wishes something done to reconcile the feud.

"He says the Demoerats will deserve a thrashing if they nominate one day earlier than the last day to which the act can be postponed.

"Train all your men, keep all their friends in hope till it's too late to back out, and then try to nominate, with a sole view to victory, is his advice.

$$
\text { "Y'rs, " O'C." }
$$

\section{R. C. ROOT TO TILDEN}

(sugGests tilden as a CANDIDATE fOR the PRESIDency) "Private.

"NE'W YoRK, 10 Feb., '68.

"Dear Sir,-I have been reflecting on the subject of next Presidential nomination suggested by you the other evening, and an seriously of opinion that I know of no one more able, or who would nearer meet all the requirements of the present crisis than yourself. The selection of any such names as those you mentioned would bring up old issues and prejudices, and insure defeat; no one doubts your ability or integrity; you, I think, could cut loose from such old associations (for they will be fatal to any candidate on our side who can't do it); you have not been worn out or antiquated platforms. Why can't such a nomination be made? I believe it would [be] acceptable to the comntry.

"If you ask me if I think that you could be elected against Grant, I say yes, if the party won't force on you a platform that says too much-(if the devil ever possessed a sensible man, it is in getting up 'platforms') ; not more than three or four cardinal points, viz. :

"1. Cheerfully accord freedom to the negro, and equality 218 
before the law; but no universal negro suffrage, nor domination of the negro over the white man.

"2. No cavilling abont the national debt, however incurred; that is sacred as honor, and must be pairl, principal and interest.

" 3 . No further patching of the Constitution of the country, nor eurtailing the independence of the Supreme Court.

" 4 . The present erroneous expenditures of the genl. government shall be redueed, and taxes equalized and diminished, and tax-gatherers shall no longer be suffered to pry into domestic affairs nor count the spoons.

"If such a platform could be put out and stuck to, not dragged ont into side issues, or dead issues, suecess would be sure; so it appears to me; but if I am only another instance of the side allusion above, it would not be strange; but $I$ would like such a nomination as proposed-there could be none better.

$$
\text { "Y'rs, \&e., "R. C. Root." }
$$

\section{S. J. TILDEN TO R. C. ROOT (PROBABLY)}

"New Yonk, Feb. 28th, 1868.

"Mr DEAR SrR,-Two suecessive absences, between which I was in town but one day and passed that ill in bed, have prevented an earlier answer to your letters.

"I concur in your judgment that the paramount issue in the coming election would be 'the restoration of the ten absent States to the Union, with all the rights and privileges of the other States, and with their local government in the hands of the white population; and that all else must be subordinate and secondary.'

"Our position must be condemnation and reversal of negro supremacy in the ten States (added to that in 'Tennessee), created by the measures of the Federal government-first, by disfranchising the whites and overawing them by military force, and, secondly, by admitting the blacks and organizing them through the Frerman's Bureau, not only involving us in a partnership in self-govermment with a mass of voters (in all the U. S. over 900,000 ), confessedly incompetent at the present time to exercise the suffrage wisely or safely, and withont any of the training, hahits, or aspirations of freemen, but, by thus obtaining control of nearly one-third 
of the Senate and nearly one-quarter of the House, establishing a practical dominion of the same character over the great free States of the North and over the whole eountry.

"Assoeiated with this issue are all those measures by which the Senate is to be paeked by the admission of new States-the subdivision of the present States-added to the control of 20 from the ten States and others constituting a Senatorial dynasty of long tenure, and the nsurpation by the Senate thus constituted of the opportunity, power, and the absorption by it and the House of the rightful authorities of the Executive and of the Judiciary.

"In my judgment, if we obscure or weaken this issue, we shall not only fail to meet the necessities of the present condition of the country, but we shall eommit a great political blunder.

"On no other question can we be so unanimous among ourselves. On no other question can we draw so much from the other side and from the undetermined. It appeals peculiarly to the adopted citizens, whether Irish or Germans; to all the working-men; to the young men just beeoming voters. The Repullican party contains large numbers who are naturally hampered by its position on this issue; and large numbers of old Federal and old Whig antecedents, who do not think that any poor man, white or black, ought to vote; and though they may go along with their party on the theory that the blacks are a counterpoise to the adopted citizens, their hearts misgive them. The pride of a superior race and self-esteem, well founded in this case, are a universal power.

"The more we concentrate the public attention on this issue, so that the people will act with reference to it, the better our ehance of suecess will be.

"Subordinate, but next in importance, is the financial question.

"The best aspect of that is its eonneetion with the other issue. It is now eosting the country, directly and indirectly, 100 millions a year - perhaps as mueh even as the whole interest on the public debt-to carry on the reeonstrution system and the measures assoeiated with it. The army expenses are now about 144 millions, exclusive of pensions.

"The best poliey on the finanees is a general attack on the prodigality and eorruption of the present governing power. Our promises should be purifieation-reduction of 
the army and navy, diminution of expenses, and remission of taxes.

"I inquired into the state and prospects of the finanees when in Washington, and am satisfied that the expenditures are now ruming at a rate much larger than the public are aware of. And the tendeney is to a fall of the revemues. I do not-" (the rest wanting).

\section{WILLIAM BIGLER TO TILDEN}

“Harmisburg, Pa., March 4th, 1869.

" MY dear Sir,-Your letters came to hand, but I have made but a very limited use of them. So soon as the diversity of feeling in the State was apparent I determined that it was true policy to avoid naming a candidate, and none will be named. On the Western border the Pendleton fever had some start. In the East and interior the friends of Gen. Hancock were disposed to present his name, and on the Southern tier of comnties there was a disposition to compliment Judge Black.

"The only name on this list, however, seriously mentioned was that of Gen. Hancock. But at the bottom of all this, so far as civilians are concerned, is the feeling and purpose I expressed to you.

"But the Young Democracy are making some trouble on our hands about delegates at large, and may defeat some of the older men, perhaps myself. Woodward is almost certain to fail. Packer will be chosen (not the Gov., but $\Lambda$ sa), and I think I shall be also; but whether in or out, my usefulness in arranging matters would be abont the same. I shall inform you by telegraph.

"Your Obt. St., "Wh. Bigler."

\section{HORATIO SEYMOUR TO TILDEN}

"UTicA, March Һ, 1868.

"Mr denr Sir,--I think Hendricks will be as good a candidate for the Presidency as we can get. I have thought the thing over and looked through the country, and I do not now see we can do better.

"I will try to meet you in Alloany.

$$
\begin{aligned}
& \text { "Truly yours, \&e., } \\
& \text { "Horatio Seymour." }
\end{aligned}
$$


FRANCIS KERNAN TO TILDEN

“UTICA, March $7,1868$.

"Mr dE.ur Sir,-Yours of the 5th is ree'd. "Mayor Spriggs and the rounger Kernans' all pleased with your congratulations and eommendations; and think they at the next election can do better even than at the last.

"Gor. Sermour is all right as to health. If he is the next Presidential candidate there need be no fear, in my jurgment, in reference to his health.

"The Governor is not in our distriet, and I have not seen him for several weeks, as I have been mostly from home at court; but I do not think he should or will be a delegate at the approaching State convention. Nor should he, in my opinion, be a delegate in the national convention. We should not allow him to be a delegate to the national convention. This would be regarded as evidence that he was not to be our Presidential candidate in any contingeney.

"Mr. D. C. Grove, editor of the Observer, is the delegate to the State convention from this district. He will be disposed to do whatever our friends shall deem best. Mr. Spriggs and I mean to be in Albany Tuesday night to aid, if we can, in consultation.

"In my judgment we should not in the State convention lay down anything like a platform of principles; leave this to the national convention.

"We might very properly in brief and well-considered resolutions denounce the revolntionary sehemes and measures of the Radicals; declare our convictions that our institutions and the peace and prosperity of the country are in danger; and call upon the people at the coming election to elect men and declare in favor of principles who and which will restore the country to peace and prosperity and preserve American constitutional liberty.

"I do not think that as a party we should take any part in the struggle now going on between President Johnson and the men who elected him.

"In reference to the eandidate for President. I think we should select as delegates our wisest and most patriotic men-men whose character will give them weight in the national convention, and who will not be influenced in their action by the views of any clique of interested politicians.

"Believing myself that Gov. Seymour is our best man for 222 
the times and onr strongest man for the canvass, I hope the delegation will be composed of men friendly to his nomination.

"It seems to me also that the State convention should, in proper terms, in reference to other States and other candidates, give expression to the confidence in and preference for Govemor Seymour as the Presidential nominee.

"I have made above snggestions in haste, and will be happy to compare views with you and other's at Albany. Let us try to act wisely, for in my judgnent everything depends upon our suceess in the next election. This country cannot stand another four years of the Summers, Weeds, ete.

$$
\begin{aligned}
& \text { "Your Truly, } \\
& \text { "Francis Iírnan.* }
\end{aligned}
$$

"S. J. Tilden."

WM. BIGLER† TO S. J. TILDEN

"Private.

"Clearfield, Pa., March 16th, 1868.

"MY dear Sir,-The newspaper's report Gov. Seymour as saying that under no ciremustanees would he consent to become a candidate for the Presidency. I sincerely hope this report is not literally correct. Such a determination would be a great misfortune for the country, and, in my judgment, a wrong to the reputation of Gov. S. The whole country understands and respects his aversion to the attitude of a candidate for the nomination, but it will never do for him to say that he will not rum if nominated, or serve if elected. He may think that there is no inclination to nominate lim; if so, he is mistaken. As the case now stands, he would certainly be selected, and his late speech will add greatly to his strength. Mr. Pendleton, it is true, seems to have strength by reason of his greenback issue, but that issue will not live till the th of July, nor will it bear examination at any time. I perceive that Mr. MeMaster, of your eity, who attended our convention, intimates that our vote will be cast for Mr. P. He is totally mistaken. One 5 th or 6th of the delegates may, at present, prefer Mr. P.,

* A fellow-citizen of Governor Sermour in Oneida County. Later an unsueessful candidate for attorney-general, and subsequent successful eandidate and member of the United States Senate.

t Governor of Pennsylvania. 
but I am convinced that by the time of the convention he will have no party at all. But the friends of Gov. Seymour desire to talk about him, and the almost unbroken reply is that he is the right man; but he declines, and we must look for some one clse. Now, we must not be left in this position. Your letter is enough, but it is dated prior to his last declination and before the State convention, and as he was not presented it may be said that the Democracy of your State are not for him." There has been, as you may be aware, an attempt to make a movement for Mayor Hoffman, at Phila., but I do not think it will extend, even with Seymour out of the way. The delegates from the South will seek to act with N. Y. and Pa., and will do what these States desire. I know this to be the general sentiment, and when Gov. Sevmour's late speech is circulated it will awaken much enthusiasm for his nomination.

"I had intended to visit you after our convention, but I was unwell and had to return home. We had things our own way. The young Democracy yielded the convention to the older men of the party.

"May I hope to hear from you at your convenience? "Very truly, Your Obt. St., "WM. Bigler."

\section{HORATIO SEYMOUR TO TILDEN}

"UTICA, March 24, 1868.

"Mr DEAR Sir, - I was struck with your speech* when I heard it in the convention, but I was weary at the time from my own speaking, and I did not feel the full force of what you said. I read it this morning by my fireside, and I wish to tell you how much it impressed me. It is not only original and philosophical, but it has the higher merit of being suggestive. It not only gives views and facts, but sets men upon trains of thought which they will work out for themselves. This gives to a speech its highest value. But a few things can be said in a speech, and if it fails to be suggestive to the hearers or readers it does but little good. Be-

* For this speech delivered in the Democratic State convention assembled in Albany on the 11th March, 1868, to select delegates to the convention which was to nominate candidates for the Presidency and Vice-Presidency at the ensuing election in November, See Writings and Speeches of Tilden, Vol. 1, p. 394. 
yond anything I have read in a long time your words at Albany have not only given me new iileas, but they have also led me into pathways of thought, where I have fouml many views for nyyself. Many of its suggestions will be worked out by our speakers into full speeches.

"I am still at my humble farm-house, ent off from learning much that is going on. I shall try to go to New York soon. It will give me pleasure to hear from you at all times.

$$
\begin{gathered}
\text { "Truly yours, de., } \\
\text { "Horntio Sermour." }
\end{gathered}
$$

"Hon. S. J. Tilden."

WILLIAN CASSIDY TO TILDEN

"April 6, ' 68 .

"Denr Tildex,-I intended to have consulted you further in regard to the Drew and Vanderbilt controversy, but did not see you after the symposium at the Manhattan.

"The struggle has got to be one of mere money. Last Sunday Drew was at Vanderbilt's honse, and yesterday the interview may have been renewed. At any time the two chiefs may compromise at the expense of their followers.

"State Engineer Bristol, Senators Morris, Niehols, Hubbard, and others are interested in the Erie, and deprecate the adverse eritieism of the Argus. Cagger thinks with you that I should keep out of the controversy. There are certainly some aspects of the controversy with which a Democratic organ should not be idcutified. I have denonnced the illegality of the over-issue and the attempt to whitewash it, and will stand by that position; lut perhaps it is mwise to go further. Our political eapital is as important to us as Vanderbilt's noney to him.

"I want you to write me on the suliject. "Your friend, \&e.,

"Wilitam Cassidy."

JOIIN A. DIX TO S. J. TILDEN

(ABOUT THE PRESIDENTIAL PLATFORA)

"Privale.

"P.ilis, 15 May, 1868.

"Mr desi: Sur,-Your letters by Mr. Cutting, Dean Richmond's friend, were cluly reed., and I did what I could for him during his brief stay in Paris. 


\section{IETTERS AND MEMORIALS OF SAMUEL J. TILDEN}

"Though withdrawn from polities, I have not lost my interest in things at home, and therefore $I$ write a few lines confidentially.

"I notice a disposition in some quarters-how extensive it is I have no means of knowing - to confine the approaching contest to a single issue - constitutional or unconstitutional government. It would be a fatal error. The contest will be severe; and, if the conservative men of the country are faultless in their tactics, it will nevertheless be close. They cannot afford to dispense with the strength they would derive from opposition to practical abuses, which are apart from constitutional questions-the financial and commercial mismanagement, and the reckless expenditure by Congress. To ignore these issues would be to dishearten all the friends of honest reform in the administration of the government and make them passive spectators of the contest.

"The power of the old Albany regency consisted in the frankness and intrepidity with which they met all public questions. The people never give their confidence to artful dodgers. Nothing will save you but a bold, manly policy. You ought to take ground in language not to be misunderstood:

"1. In favor of bringing back the Southern States on the same terms as the others.

"2. Of maintaining inviolate the public credit.

"3. Of returning as speedily as possible to specie payments, and of reducing forthwith the paper circulation.

"4. Of repealing, simultaneonsly with the resumption of specie payment, the act of Congress making paper a legaltender.

"5. Of reducing the enormous duties on imports, which are destroying our commerce, and will ultimatcly react most injuriously on our agriculture and manufactures; and

"6. Of reducing the public expenditure by a rigid system of economy and lightening the burden of taxation.

"Nor will this be sufficient, unless you present to the people, as the exponents of these principles, men who are known to be their tried advocates, and who in the late Civil War were active and unqualified supporters of the government. With every advantage on the other side, Gen. Grant will be a hard man to beat. It is but a few months since the Democracy thought seriously of making him their candidate; and there are multitudes who do not believe, and can226 
not be made to believe, that he will faror ultra measures of government, under whatever auspices he may be elevated to power.

" Having given you all this good advice masked, it only remains for me to say that I am glad to hear you are to be a candidate for Governor next fall, and that $I$ am, as ever,

"Very trulv Yours,

"Jolin A. Drx.*

"Hon. Saml. J. Tilden.

"P. S.-What a folly it was to talk about paying in paper a bonded debt $(5 / 20)$ not due for years to conne! We shomld hold our tongues and settle the question by resuming specie payments."

WM. S. HAWLEY TO S. J. TILDEN

ADVOCATES TIIE NOMINATION OF S. P. CIIASE

"Hon. S. J. Tilden.

“ $N . Y_{.}$, May $22, ' 68$.

"MY DEAr Sin,-I returned from W. this A.M., having left there last evening. I did not see the President, as Randall thought it best that I should not. Had two eonversations with Randall-one in the morning, the other in the afternoon. Between the two conferences the Governor had an interview with the President in relation to the future action of the administration. Randall said no action could be taken in regard to consolidating against Grant until after the 26 th. The Johnson men would be glad to have a conference with you and your frients in New York at any time you would name after the 26 th here in $\mathrm{N}$. Y. The first name he mentioned, upon which a consolidation eould be effected, was Hancock. Afterwards mentioned Chase, as upon him more Senators eould be brought than upon the former. He mentioned the names of several Senators who would support Chase beside the Republican non-impeachers. He asserted positively that ('hase would acept a momination from the Demoerats and Conservatives. That Chase's negro antecedents conld be got along with by adopting a plank in the platform giving each State, or rather conceding to each State, the management of the franchise question. He also

* General Dix had been appointed by President. Johnson Minister to France in 1866 . 
said that shonld ('hase be nominated there would be no lack of 'material aid' to earry on the campaign successfully.

" My opinion is that if our convention could be brought to nominate Chase, with IIancock, we would sweep the eomntry, and on the fourth of Mareh next have a working majority in the Senate.

"Randall also suggested that you get some of your commercial men to write to the aequitting Senators, thanking them in the name of the great interests of $\mathbf{N}$. Y. for their votes, and especially Senator Grimes.

"I hope that the proposed conferenee will be held, believing, as I do, that it will result in the overthrow of the political ascendency of the Radicals; at all events, it can do no harm, as I am entirely satisfied that the Johnson interest would see the Demoeracy succeed rather than the Rads, even if they are not recognized.

"The Times of this morning eopies an article from the Argus, and, if I can read the article and understand it aright, it is a feeler in this very direction.

"I shall publish a leader, when I return home, of the same import, but a little plainer, withont mentioning any names, and we will see what comes of it.

"One other thing. Randall intimated to me that the President and Smythe were not on as good terms as they might be. The President did not take his last offer to do a certain thing, provided he would give him the mission to Austratia. The President thought it would have been better in Smythe to have paid up arrearages before asking further faror's.

"Randall said other Senators would have voted for acquittal had it been neeessary.

$$
\text { "Confidentially Yours, }
$$

\section{S. E. CHURCII TO THLDEN}

"Private.

" Rocinester, June 10, 1868.

"Desr Sir, - What about the military organizations being represented on the 4 th of July? Is it to be general? If so, a call from some military man in this State shonld be issued at once. In whose interest is this military representation called? With such a body in scssion asking for a 
military man, ean you refuse putting one on, either at the head or tail of the ticket? Sone of our military friends in this section of the State are anxions to know about it, and if it is gone into we had better lirect it. Please give this attention. I don't expect an answer.

$$
\text { "Yours truly, }
$$

"Chase is out of the question. He would be the weakest man we could have. We will use him well, but must not think of nominating him.

"The more I consider the question the more I am inclined to favor Hendricks. He would make a good eandidate.

"I think we cannot fail to sueced at the election. The other side are dying with the dry - rot, and the people are looking to us for relief. Let ns not fritter it away. We rely on you and some of our discreet friends to keep things steady."

\section{A. LOOMIS TO S. J. TILDEN}

\section{"Hon. Shmuel J. Tilden:}

"Little Falls, June 8, 1868.

"Public opinion is being rapidly formed in relation to the eandidate for the Presidency at the next election. Your position is potential in influence. I take the liberty of addressing you in advance of the convention to urge upon you and through you upon our Democratic friends to insist, with all our State and Democratic pride, prestige, and weight of influenee upon the nomination of Gov. Seymour unless fairly overruled. Gov. Seymour's conrse during the war was so nobly somd and Denocratic that he attained a very strong hold upon the eonfidence and affections of the Demoeracy of this and of all Northern and Western States. His name will, I assure you, develop a hearty enthusiasm among Demoerats that ean be drawn out by no other. The hope of wimniug friends from our adversaries by taking up a man who has been identified with the other party finds little enemragement in our past experience. Those who do not hate the Radicals worse than they do Demoerats will continue to rote with them. It will not be love, but its opposite, that will control their action. Tet us stand by our principles and ly those who have maintained them when 
trampled nuder foot by the despotism inspired and prompted liy war. ('hase's record is not a good one; it has great defects. Ambitious politicians may deem his acquisition a hargain; but I tell you his name has no strength with Democrats. That pride, in and for the men and for the principles which he has assisted us to sustain in dark times, which Seymour's name would command, will be thrown away withont him, and especially with a candidate so recently a leading man in the administration of Mr. Lincoln. The election of Lineoln, taken with all its consequences, was about the greatest calamity that ever befell a great nation. The Democracy all over the land, though hushed to silence by the war spirit, feel it to be so. They ache for an opportumity to show their zeal and their strength. I have no doubt but that Sermour's scruples may he overcome if he deems the interests of the comntry at stake. I must say that I think his unqualified declension has been injurious to his success in being nominated, but not in being elected if nominated.

"In my judgment, Pendleton's name stands next to Seymour, though I suppose X. Y. eity thinks otherwise. His theory, as he himself explained it, was not so very objectionable as some of the $\mathrm{N}$. Y. financiers scem to suppose, but the answer and cure of all that question between greenbacks and gold will be settled under a Democratic administration very shortly by the resumption of specie payments, and this is and should be the only answer to it. With Seymour at the head, take Hendrix for vice. With Pendleton, take, possibly, C. F. Adlams, or, better still, our own Church. I believe the Democracy have the power and the will to restore the government to common-sense and the Constitution to its position as the fundamental law of the land, and I believe it must [be] done through the angency [of] men who have not swerved from their principles, whether in peace or war.

"With Great Respect, Yours, \&c., "Arphaxed Loomis."*

* Mr. Loomis was best known in his day as an associate with David D. Field in drafting the Civil Code for this State. He had no sympathy, however, with the Lincoln government, its origiu or conduct. He was a man deservedly of much influence by virtue of his sterling character and good-sense. He exerted no inconsiderable influence in shaping the revised Constitution of the State of New York in 1866. 
W. IF. ALLEN* TO TILDEN

"Comp'rolder's Ofwice, Mllany, May 2j, 1 stis.

"MY DEAR SiR,-Is it not about time that you were instrueting the faithful how to vote in eonvention on the 4th of July? I feel that I have been kept in ignorance about long enough. I would like to know now who I am expected to hurral for then, so that I ean make aftidavit that he is the spontaneons choice of the people, and is to be elected by acclamation. It is no great thing to be nominated by acclamation, but if we can shout our man into office it will be a 'big thing.'

"I fear that we are to be embarrassed by the want of a candidate to oppose Mr. Pendleton. Grov. Seymour shonld have eonsented to the open using of his name, or else we should have agreed upon some other man. Is it possible at this late day to unite upon a man with whom we ean head off Pendleton? I fear that we cannot go into the fight with great confidence and enthusiasm with him as our standardbearer.

"Can we not nominate some one who will be acceptable to the Evening Post and those who are denouneed by the Radicals as unsound on the impeachment? I think Bryant would be satisfied with yourself, or some one else that you could name?

"Has Farragnt been heard from, and what of him? I am for a fight to win.

$$
\begin{aligned}
& \text { "Truly Y'rs, } \\
& \text { "W. F. Allen." }
\end{aligned}
$$

\section{S. L. M. BARLOW TO TILDEN}

(FAYORS CILASE FOR PRESIDENT)

“NEW Yokk, Junc 21, 1868.

"Mr DEAr Sir,-I am more impressed even than when T saw you as to the neeessity of you secing Mr. Chase, as I have just seen some influential Demoerats, one of them practically representing a State, who tell me that they are for Chase first, last, and all the time, hecause:

"1. They helieve he can win.

* Mr. Allen was a kinsman of Sandford E. Church; had heen a collector of Internal Revemuc; Was Comptroller of the State at the date of this letter, and subsequently became a judge of the Court of Appeals. 
"2. Because it is a necessity for them, by their political action this fall, to show that there is no practical barrier between the races, and that this can be done in no way so well as by Chase's nomination. They are in earnest, and will not yield their eonvietions lightly.

"If he will answer for Carolina on the negro question, I do not know but we could take him.

"Friday. "Y'rs, $\quad$ S. L. M. Barlow."

MONTGOMERY BLAIR TO TILDEN

"WAsHo., June 5th, '68.

"MY dear Tilden,-I send another missive from Frank by which you will see his hopes are revived. You asked me to keep you posted, and therefore I send these advices, as they come to me intended only for me. I think the Chase fever will die out and will help Frank in the end. I wrote Barlow yesterday, who seems, by the way, to be enthused about it, that it was regarded here as an attempt like Pendleton's to subordinate the great constitutional questions involved in the reconstruction measures-a question which is fundamental and will determine whether this is to be a free govt. or not-and the subordinate one of whether the debt was to be paid in gold or greenbacks. It is impossible that the public mind shall make such a diversion, and those who attempt it are swayed by personal, not public, interests, and can have no real hold on the country, and no comprehension of the serions mood in which the people are at this moment. You, who really believe in the people and have faith, a real faith, in the Democratic philosophy, ean comprehend how dangerous it is for the leaders of a great party to trifle with this subject, and that it is trifling with it to set up a man as the representative of a cause who has no heart in it, and only beeause he has quarrelled with his own party for their daring to prefer another man.

"The Chase spasm will help Frank by loosening up of the party feeling and antagonizing Pendleton. If any Democrat can go for Chase a priori they can go for Blair, and Frank* will carry just 10 Republican votes for every

* Frank P. Blair was a son of the former editor of the Washington Globe; he had been a Member of Congress from Missouri; he served in the Union Army during the Civil War, and attained the rank of 
one that Chase ean carry; for ('halse has not the slightest influence with the only class of Republicans who are disposed to go with us, viz., the Lineoln men. He was an active Ratdical, and the Lineoln men would delight to have him beaten. He was the only hmman being that I believe Iincoln actually hated. Our ruming Chase would fix thousands to Grant, who would ecrtainly go for us with Frank as a leader, Frank being really the true heir to Lineoln. Lincoln sent for him from the army to defend him and to assail Chase on the floor of the Ilouse of Representatives, and Lineoln, you remember, published his letter to me requesting my brother to leave his command and take his seat in the Ilouse of Reps., promising to restore him his commission as soon as military operations were resumed, which he did to the chagrin of all Chase men.

"I had a great contest to get into the conrention. The B. \& O. R. R. and Pendletonians exerted themselves to the utmost to defeat me, but by the sheer pressure of public opinion in Baltinore I was carried through. At every mention of my name in the convention the immense hall rang with the applanse of the people, and I got 18 of 21 city delegates, altho' every man of them had been pledged against me.

$$
\text { "Y'rs truly, } " \text { M. Blair." }
$$

R. J. WALKER, * SECRETARY OF TIIE TREASURY UNDER PRESIIEN'T POLK, TO TILDEN

\section{"Confidential.}

"Wasmington, D. C., May 30, 1868.

"DEsR Sir,- When you were last in Washington you were pleased to ask my views as to the candidate who ought to be nominated by the Democratic convention for the Presidency. I gave yon my opinions then very briefly, but the great events which have transpired since that period have,

lorigadier-general. He was nominated in the fall of 1868 as VicePresident on the Democratic ticket which selected Horatio Seymour, of New York, for President. General Grant was selected by the Republican party as its candidate for President, with Colfax, of New York, for Vice-l'resident. The Republican ticket was suceessful.

* Mr. Walker had been a Senator from the State of Mississippi, and subsequently Secretary of the Treasury nnder l'resident Polk. 


\section{IETTERS AND MEIORIALS OF SAMUEL J. TILDEN}

in my julgment, settled the question conclusively. Our strongest man, and the only one who can certainly be elected, is Genl. W. S. IIancock.

" My reasons are as follows:

"1st. Pennsylvania is the most doubtful State in the Union, and has always decided contested Presidential elections. The reason is not only the closeness of her rote and the great number of her electors, but that her State elections precede by three weeks those in other States, and thus influence beyond calculation the result of the Presidential election. Hancock is the only man who can carry that State. His nomination from that moment would give us the prestige of certain success there, and a probable majority of 50,000 in our faror in the October election, which would immensely influence other States in November following. He is a Pennsylvanian by birth and education, and by far the most popular of her soldiers. He commanded in person more of her troops than any other man, leading them always to victory, especially at Gettysburg, to Pennsylvania the decisive battle of the war.

" 2nd. Abont one-third of all the voters of the North were soldiers during the recent war. Recognizing this, the radical party have nominated Grant. We must receive a large proportion of that vote in the coming contest or we are defeated. No Democratic candidate can receive anything like so large a proportion of this vote as Hancock. From the commencement to the close of the war he has commanded, in person, огer three hundred thousand troops, and both officers and men were greatly attached to him. His military record during the war was most brilliant, and will bear the closest scrutiny and the most favorable comparison with that of Grant.

"3rd. He would be more acceptable to the South than any other military candidate, many prominent Southern leaders and newspapers having announced their preference for him. Especially is this the case with her wisest men, because, whilst recognizing his sound Democratic principles, suceess is to them a necessity, and they believe that his nomination would make our victory certain. They do not support him with reluctance, but with enthusiasm. His humane, able, and statesmanlike administration of the affairs of the 5th military district, at a time when all seemed lost, when every other military leader had either gone over 234 
to the encmy or concealed his views, gained him their respect and admiration.

"4th. Hancock has from his youth up always been a Demoerat. In taking him we do not rely upon a man of doubtful or vacillating principles, but one of our faith, with the firmness and the conrage to maintain it.

"5th. Hancock, I believe, would make a President of whom not only our party, but our comntry, would be proud. He would unite and strengthen the party, and his firmness, good judgment, and total disregard of political trickery would lead us safely throngh the coming crisis of our national affairs.

"6th. No man can foreshadow the events of the next. four years. Are they to be peaceful or warlike? And how is the latter condition to be aroided? We must nominate a man who can certainly be elected, and whose name at the head of our Presidential ticket, whilst giving us the prestige of certain success in that campaign, will give us strength to carry the Congressional eleetions. Has any such man been thought or spoken of except Hancock? I have heard of none. Besides, you will recollect that, by unconstitutional legislation, Grant has been made the virtual commander-inchief of the armies of the United States. We must have for his commander-in-chief a man who has the ability, the courage, and the firmness to command him. Such a man is Genl. Haneock.

"This will be the great struggle for the supremacy of one or the other great party of the country. A written Constitution against a popular, if not a military, despotism. If we fail now we may be lost forever, for a civil war alone conld tear down the harriers which the Radical party would erect against our liberties. They would then have, as now, the Senate and the House, the legislative departments. Then, as now, by similar intimidation, earried to a greater excess by their victory, they would suspend the functions, as they pleased, of the Supreme Court, the judicial department. They would have also the executive department, thus securing substantially all the departments of the government. Do you doult the extent to which they would carry their revolutionary doctrines? And would the Senate any longer be a curb upon the frenzy of the Trouse, with an addition of 20 members from the negro-ized Sontl? We must start out, casting aside all personal preferenees and prejudices, 


\section{LETTERS AND MEMORIALS OF SAMUEI, J. THLDEN}

determined to succeed. We must select the man who can secure the most votes, and who will be supported with enthusiasm by every Democrat, war or peace, so-called, by every conservative Democrat or Republiean soldier, and by the thousands of new recruits and conservative Republicans. I think that Genl. W. S. Haneock is the only man who would receive the combined, enthusiastic support of the people South and North.

"I know that, if you concur with me in these views, you will not hesitate to use every effort to secure by this means the suceess of that party which is dear to us both. I have written you because I knew that you would not misconstrue my motives, and because I believe that you can exert great influence for the good of our country. If there be reasons which I may have overlooked, in forming a deliberate judgment upon a subject which has cansed me much anxious thought, I should be very much pleased to hear them from a friend like yourself. Let us have harmony in our councils, and with wisdom suceess is ours.

"Very truly your firiend,

"R. J. WALKER."

\section{TILDEN TO THE TAMMANY SOCIETY}

“July, 1868.

"Gentremen,-Regretting that I cannot personally attend the celebration of the Fourth of July by the Tammany Society, to which you have invited me, I nevertheless concur most cordially in the patriotic sentiments so eloquently expressed in the address of the sachems.

"Your venerable society may well felicitate itself upon its political retrospeet. It did everything in its power to avert civil strife by a policy which was represented as too conciliatory by those who did not comprehend the danger. When the conflict of arms came it cordially maintained the nationality of our people in a confederated republic, which Jefferson and Madison and Jackson aiways held to be incapable of being dissolved except by a revolutionary destruction of the Constitution. And now that peace has once more happily returned, it clains that constitutional rights shall be restored throughout our whole country; that every State shall be replaced in its constitutional orbit; that we shall onee more present to the world a continental system of 236 
States, bound together by a constitutional union-fomded on the twin principles of local self-govermment and industrial liberty, and sustained lyy the voluntary action of a people anong whom govermment is everywhere carried on by the consent of the goremed.

"Alas! that this henign work of peace should be more diffieult than the fieree strugegle of war. But so it is.

"Multitudes of our fellow-citizens are so infatuated with fear of the danger of dismion, which has now passed, that they create a danger of centralism fatal to all liberty-to all constitutional goverument-and at last by inevitahle reaction to the Union itsolf:

"Instearl of restoring the system of om fathers, the purpose to do which alone consecrated our caus against secession as righteous, they would erect upon this fair continent eleven Polands, eleven Inungaries, eleven Irelands!

"And the same prineiples of despotism which they would apply to our recent enemies they freely extend to the whole Northern people.

"I say the prineiples of despotism. For centralism is despotism. Was centralism erer hefore so rampant as now? the distinguishing characteristic of the controlling element of the so-called Republican party which now sways the two Houses of Congress is a total disregard of all limitations of power established by our written Constitntion; an overwhelming contempt for all fundamental law, whether State or Federal.

"No right of localities or of individuals is deened salered.

"The principles which underlie our whole political system are not respected; they do not seen to be even comprehended.

"The present Congress and the adranced Republican party are a rule enuto themselves. Their own opinion of what it is convenient or experlient they should do, is the only limitation of power which they acknowledge; and it is their opinion that they should do pretty much everything, in all places and with respect to everyboly.

"Of course, such a false system of political philosoplyy loes now, as it has in all ages, immerliately degenerate into selfish rapacity. Congress is mainly oceupied in putting new manacles on the trade and industry of the conntry; and the more respectable representatives of the prevalent politi- 
cal ideas are roting money out of everybody's pockets into their own.

"In this condition of things nothing but the principles of the Democratic party, as maintained by Jefferson and Jackson, ean save the country. There is no organized agency which can give effects to these principles except the Demoeratic party, with such allianees as it may form in the cause of liberal government.

"From the day of the accession of President Johnson I have felt renewed confidence that the American people would not only maintain our national mity, but would reconstruct our political institutions on their ancient foundations.

"The political ideas of Jefferson and Jackson in which President Johnson was educated, and which have become incarnated in his very nature-the character of the work he was providentially called to undertake in bringing back into our system the people of eleven States lately in revolt, which he conld only do by addressing the intellects and sentiments of that people-were guarantees that he would recur to the original fountains of our American principles of government.

"As for us, we could not but accept what we had sought when we endearored to elect McClellan: first, the re-establishment of national unity; secondly, the starting the restored government in its new career upon its original and true principles.

"The situation controls. Not the plans or wishes of individuals.

"In my judgment, neither President nor the Democratic party could stop what events so clearly commanded.

"Last year, at your Fourth-of-July celebration, I promised him in rour name, in the name of the Democratic party, and of your acclamations, a liberal co-operation in the great work; and afterwards repeated that assurance in person.

"The time has now come when all parties who favor" President Johnson's plan of pacification must act with reference to the election of the next Congress.

"President Johnson will now he uncler the necessity of appealing to the whole body of the people, accepting all who come to him on the issue he has made, and separating from all who go against him on that issue. 
"If he should attempt the narrow and futile scheme, nrged upon him lyy those who are neither his friends nor the friends of his cause-of carrying out his policy through the exclusive agency of the Republican party, in ease he can capture it and convert it to his purposes-he will find his machine turned against him in the hour of his need. He will find hinself, like the unfortunate object of 'Turkish jealousy, tied up in a loag, to be silently strangled. I do not doubt that he will act on the larger policy which would have governed Andrew Jackson or Henry Clay under like circumstances. He will east himself upon the whole body of our people, leaving parties and organizations to take care of themselves. He will be triumphantly sustained.

"The Demoeratic party should pursue a liberal policy in all its action, and accept as brethren all who stand with it on the present issue. It is too powerful to be jealous. It las too great a motive in the restoration of its own traditional principles of government to an ascendency in the councils of the country, which they made great, prosperous, and happy, to think of anything less grand or less noble.

"With much respect, I remain, gentlemen,

$$
\text { "Y'rs truly, }
$$

\section{"Personal.}

\section{TILDEN TO FRANCIS KERNAN}

"Mr dear Sir,-I had no agency in getting Gov. Seymour into his present scrape, thongh I would have been glad of his nomination if his consent could have been freely given. I yielded to his wishes ont of tender regard for him. And I feel now that I am the last man who can with delicacy bring a pressure to bear upon him; but my judgment is that acceptance, under present circumstances, would not compromise his reputation for sincerity or be really misunlerstood by the people; that the case is not analogous to the former instances which have made criticism possible; that the true nature of the sacrifice would be appreciated; while, on the other land, the opposite conrse would be more likely to incite animadversion; that, on the whole, acceptance is the best thing. I tlink a decision is necessary; for it is not possible to go thro' the eanvass with a candidate declining. I am sincerely willing to acerpt such action as will be most 
for the honor of our friend; at the same time my personal wishes faror acceptance. You maly express for me so much in this respect as you find necessary and think proper. In haste, but

Truly yours, “S. J. Tildex."

\section{R. W. LATIIAM * TO TILDEN}

" Wasmington, July 19, 1868.

"Mr denr Sir,-I tried to see you before leaving New York last week, but failed to do so.

"It is vastly important for you to have the reporters of the press of this city, who make the views and give the tone to every important newspaper in the country. They are now in an organized state, and if done at once can be controlled for Sermour and Plair.

"The Grant men have declined to pay them any money, but offer largely in case of success. This don't suit.

"It will take abont 8000 to $3500 \$$ per month until the campaign is over to secure these men, about 30 in number, and they are worth more than all the stump orators in the field, and if I had the control would pay them, if necessary, $10,000 \$ \mathrm{p}$. month, or so much as would secure them.

"There are no such men in this country as the reporters stationed here for energy and smartness.

"If you can get Gor. F. P. Stanton, upon whose titlehead I write, to take charge of the money and disburse it, you must sneceed. Gor. Stanton is treasurer of the Chase committee here. He is brother-in-law of Mr. Perrin, who was secretary of your convention.

"Can't you conse or send some reliable man here at once to attend to this matter"

"Let them call on Stanton, who is posted.

$$
\begin{gathered}
\text { "Your friend, } \\
\text { "R. IV. Latilam." }
\end{gathered}
$$

\section{F. P. BLAIR TO TILDEN}

"Silver Spring, 15 July, '6s.

"Mr dear Tildex, - The day after I got to New York Bennett sent his carriage to take me out to dine with him. He did not talk farorably of Chase, but as an antagonist of 
Seymour, whom he considered to be at heart opposed to him. He spoke well of Frank, and intimited a purpose to support lim if nominated. The day before I left the city Montgomery and myself called at his oftice. He said he wonld have supported Frank eordially, but insisted that now it was Grant is. Seymonr, and the former w'd sueceet. His son, in whom all his hopes and affections are homnd up, is greatly attached to Frank. Is it not worth while to work on the old man's personal vanity and his ambition for his son's advancement in the party's consideration to get him into line to help our canse? Lawrence Jerone is deroted to Frank, and Bennett's son to hinı. Jerome is out for Frank, although he onee subseribed to Grant. I think through him, by proper management, we might get hoth of the Herald. Whatever may be thonght or said of this fickle print, it is a power in the body politic through its vast circulation. I think it might be led to make a transit to Sermour by means of its inclinings to Frank; and Terome would be a safe eonduct in this matter, as he and Bennett were both shipped onee for Grant, but now prefer my hero. They want a hero, and so does our cause; and although Frank is a mighty small young Hickory, he is the best we ean now command. Do try and make something of these sugecstions; we have so good a cause, and its suceess is so essential to the welfare of the country, that some condescensions to the old Phutus (or Pluto, if you please) might be a cheap purchase of a three months' command of his colmmms. If my seribblings in them could be of use in reviving menories of the Tackson-Van Buren era and the prosperons times it brought about for the Republic, I would give a part of erery day to inveigh against the monstrons doings of the banditti that now set up for a Congress-and it would be by way of contrast.

"I believe the convention, although it seems to have been by aceident, really made the wisest disposition, both as to the ticket and the platform that conld have been devised. Seymour's eloquence and polish and moderation has a happy influence to recommend us to the refined and all who are apprehensive of rash comnsels in this crisis. Frank's boldness and thorough grasp of all the issues which are looked to as neecssary to put the Demoeracy at once in possession of the cood, will do much to rally to our stamblard all the zealots for the instant overthrow of the corrupt military despotism that now lords it over the land. 
"I enjoin it on you to gire your sister that dollar I promised to return through you and you w'd not take; I insist on a specific performance for the honor of

$$
\text { "Yr. mo. afft., }
$$

"F. P. Blair."

\section{HORATIO SEYMOUR TO TILDEN}

\section{"Utica, July 20, 1868.}

" $M_{\Gamma}$ deAR Sir, - I have given much thought to the subject of organization. I am satisfied a new course must be taken. I do not count in any degree upon the national committee. It will do nothing from the nature of its organization. We have been a long time out of power, and are apt to call upon those who used to be efficient without making allowance for the change made by time. We only need organization. The moment we get it we shall become aggressive. We can get no vigorous organization without putting our young men into the field. To do this we must give them a motive as well as a method for action. This has been done in New Jersey and Connecticut by the Jackson clubs. They are, to a degree, secret organizations. This gives them the charm of novelty, as we have heretofore had nothing of the kind on our side. They hold out a motive to the active young men, as they give to them power at once in their localities. James Spencer, Esq., of New York, and Mr. Palmer, of Wisconsin, called upon me last week with a plan of the kind, which I think is the right thing. They are both good organizers. This scheme is the most efficient, and costs the least. When a club is formed it is not only self-sustaining, but it does a great deal of work at its own cost. If men are sent at once into Maine, Indiana, Ohio, and Pennsylvania they will in a little time give such a start to the morement that it will go on of itself. Time is everything, and it is my opinion any other method should be dropped and this plan entered upon. It has freshness, cconomy, and simplicity to recommend it. It appeals to young men, as it gives them something to do, and also gives them strength and power in their towns. I wish you would see Messrs. Spencer and Palmer when they call upon you. I am quite well now, but I am suffering with the rest of mankind from the heat. I am overwhelmed with letters. 
Of course, all I get are very satisfactory. Our papers should keep up a steady fire upon the subjects of debt, taxation, ete., ete.

"Hon. S. J. Tilden."

$$
\begin{aligned}
& \text { "Truly yours, \&e., } \\
& \text { "Horatro Sermodr. }
\end{aligned}
$$

\section{F. P. BLAIR TO TILDEN}

“Silver Spring, 10 Aug., '68.

"Mr dear Tilden,-Your Milwankee speech has done me numch good-a thing not to be thought of if it were not that this good done to one obsemre individual extends to the whole country, when everybody is alike advantaged as I am. Your exposure of the terrible cost the whole nation is put to in maintaining an army to hold one portion of it in subjection makes it plain that the entire commonwealth is subjected. That section of ours which bears the tax (more than England and France both bear to enslave two empires), to keep the South under the foot of our quondam slaves, ecrtainly gets less for its money, although laid out in producing a rery thorough despotism, than the imperial dynasties abroad. You have made a eapital demonstration of the enormity of the flight into tyranny which our Radieals have made in a short time, from the vantageground they obtained in the war over our free govt. 'The North sells itself into debt and slavery to enslave the South.

"But I owe you something more than the commonalty for your speech-rour making my son a great man, giving him the heirship of Old Hickory's glory, although I know it is far beyond his reach, fills me with delight. You put a brilliant rainbow before my eyes, and tell me there is a pot of gold where it stands on the eartl. The vision pleases, however, sensible that no effort will find its footing on the ground. Yet I hope Frank's aspirations will not all prove delusions to him or his father. Te has all Old Hickorr's devotion to his comntry, and he has the courage to attempt its redemption from the hands of the banditti that has for the time seized on all its wealth and all the defenees of its liberties, and $T$ have faith in a providenee to overrule it, so that my roung stripling who is put forward in the battle 


\section{IETTERS AND MEMORIALS OF SAMUEL J. TILDEN}

against the Philistines may do some execution with his sling.

"I beg you write me a line to say what promise you bring from the West. I have some influence with Bemnett. If you think well of it I will write to him and urge him to open his columns to us. I think if Frank made well-considered speeches Bennett would Herald them.

"Yours afft.,

"F. P. Biair."

"MY DEAR TILDEN,-My father wished me to mail this for him. I agree in what he says about your Milwaukee speech. It was unanswerable in argument as to Frank's coming East. I am glad he has declined doing so. His letter to that effect came yesterday, saying he did so because you had advised him to confine himself to the West. $\mathrm{He}$ has made no speeches, except some off-hand efforts at receptions, etc., etc.

"Y'rs truly, "M. BLAIR.

"Wasin., Aug. 15, '68."

\section{HORATIO SEYMOUR TO TILDEN}

"UTICA, August 1\%, 1868.

"Mr DEar Sir,-I send you three letters got to-day: one from Chicago about Indiana and Illinois; one from Grovernor Haight, of California, about the Pacific States; one from Henry D. Barto, of this State, who writes about the mining States. You know him as a gentleman of sagacity and stancling. Of course, eandidates always get flattering statements which prove nothing. But these letters, like all the letters I get, use the same language. Indeed, if my letters were not dated from different States I should think they were all written from one locality. This uniformity of words and facts means a great deal. It foretells a political change.

$$
\begin{aligned}
& \text { "Truly yours, \&c., } \\
& \text { "Horatio Seymour. }
\end{aligned}
$$

"Hon. Samuel J. Tilden." 
AGREFMENT OF AUGTST IELMONT, SAMUEI. J. TILDEN, AUGUSTUS SCHELL, RICHAl, SCIILL, GEOLGL I. MALE, THOMAS

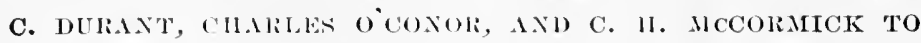
SUBSCRIBE $\$ 10,000$ EACIL TOWARDS ELECTION EXPENSES OF CAMIDIGN OF $186 \mathrm{~S}$

"We, the undersigned, each for himself, hereby agrees with Angustus Schell, ('hairman of the Demoeratic National Executive ('ommittee, to pay to said Sehell each ten thonsand dollars in such instalments as he may eall, which sums shall be expended in such mamer as the national Democratic committee shall doternine, to defray the just and lawful (xpenses of circulating doemments and newspapers, perfecting organizations, etc., to promote the election of Seymour and Blail.

"It is molerstood that if in the judgment of said committee the subseriptions for the purposes of the said election not embraced herein shall render it umecessary to expend the whole amount hereto subseribed, then any surplus which shall remain shall be refunded to the subseribers in equal proportion.

"New York, Aug. 15, 1868.

"August Beliont,
"S. J. Tilinen,
"Augustus Schele,
"Richo. Schele,
George I. Mhaee,

Thos. C. Durint,

Cir. O'Conor,

C. II. MCConmick."

MI. BIAIR TO 'TILIEN

“A $\mathrm{ug} .19,1868$.

"MY Dear Thidex,-Y'rs of resterday has eome to hand. Mr. Welles is now at the Kittery Yard in person, and will not be here for a week perhaps. He las probably done what Shaw and friends ask. If not, 'twill be too late to act, I fear, on his return. Welles is very earnestly with us now, and I have no loubt will do anything he can. My aceounts from the West agree with your's as respects political prospects there. Put Able, who is not of a sanguine temperament, writes that our friends are going to carry Missouri by 20,000 majority.

"From Maine, Mr. Clapp, former M. C. from Portland, 245 


\section{LETTERS AND MEMORIALS OF SAMUEL J. TILDEN}

a brother of Mrs. Woodbiury, who is also a cantious man, is rery confident of gains in the State.

"If my father ean go on to New York I am sure he will do so, to see Bemnett. 'The truth is, however, that Bennett looks to position, and there is no getting him withont assurances of it. It was in this way that Lincoln got him. $\mathrm{He}$ could have been nominated to Paris undoubtedly if he had not himself declined accepting the mission, because he would have been rejected. Chase got his support, I am sure, by promising him this mission if he was elected. The negotiation with Jineoln was carried on through a fellow of the name of Bartlett, who was the same man who got the Herald for Frémont. I had no part in either negotiation, but I knew of both and sustained Lineoln in keeping his bargain with Bennett. His inclinations are with our side, I am sure, and he told my father and myself he would have supported Frank's nomination earnestly.

"I would not hesitate myself in supporting him if he would give us the power of his press to elect our ticket. I regard him as every way a most reputable man, and one of far greater ability than Chief-Justice Chase. I said this to one of Chase's hangers-on one day when he was turning up his eyes at Lincoln's appointment of Bennett.

"If Seymour could support Chase for the Presidency for his doings about impeachment I cannot see why he could not appoint Bennett for helping to save the country.

"Seymour" ought not, under any ciremustances, to be approached on this matter. But I think we might legitimately hold out hopes to Bennett and keep our promise of support in good faith. I would, for myself, mulhesitatingly offer to do my ntmost to get the President to appoint him, though I would not offer that Seymour himself should cone under any promise about it, or indeed be approached on the subject directly or indirectly.

"Of course, I would not be so explicit on this subject with any one else. But with you I talk freely, so that when the old man comes on, if he should, yon will be prepared to take ground on the point in question.

"Y'rs truly,

"M. BLAIr.

"Whisi., Aug. 19, '68." 


\section{LETTERS AND MEMORIALS OF SAMUEL J. TILDEN}

HORATIO SEYMOUR TO TILDEN

"UTics, Sept. 26, 1868.

"MYr deAr Sir,-The canvass has rum on for more than two months, and the questions of the day have been discussed in journals and meetings by so many different minds, and in so many different modes, that they are somewhat confused in the public understanding. Would it not [be] well if at this moment we could get a fresh presentation of our purposes in a way that wil arrest public attention and in a way that will meet the points urged by our opponents, as we now have a need of their position? I have been talking the matter over with Mr. MeCormick, in whose judgment I have great confidence. Now, every candidate for the Presidency must have a 'privy council.' There must be a number of men upon whom he can lean, who will help to shape out before election a line of policy which will carry the comtry through its difficulties. Able, influential, and thoughtful men should know now what they can rely upon in the event of our success. With clear ideas on these points they can work with more vigor, ete. Would it not be well to have a meeting of ten or twelve persons who should talk matters over clear through the coming year? Should not some definiteness be given to our future plans? Could not some position be taken now which will do good in the way of foiling the attacks of our opponents? Up to this time, with the exception of my consultations with you and two or three others, I have been almost isolated in my position. 'There are many advantages in this, but it should not be held too long.

"I am anxious to sce you, and if it be possible for you to meet me here or elsewhere I should like to have a free talk with you. I will write to you soon about taking the field myself.

$$
\begin{gathered}
\text { "Truly your's, de., } \\
\text { "Horatio Sexmour." }
\end{gathered}
$$

\section{HORATIO SEYMOUR TO TILDEN}

“Utics, Octobrr 1, 1 s68.

"MY Dlar Sin,- - Yours of the 30 ult. is received. T see nothing nore to be done in Penna. beyond comnteracting the effects of the soldier's neeting. This is a movement upon 
which the Republieans count largely, and upon which they have spent large sums of money. Now, the éclat of this will not depend upon the soldier's, but the generals who will be in attendance. Can this be done? Get Generals MeClellan, Haneock, Franklin to go to Philadelphia on Thursday of next week. Give them a reeeption. There will be an immense turn-ont of the citizens. The Republican meeting and the near approach of the election will furnish all the stimulants needed. As it will be gotten up without parade or all the notes of preparation which have gone before the Republiean show, it will tell more on the public minds. The soldiers thronghout the country look to see how the popular generals go. We can make the best show in that way. I learn that Haneock has not been asked by the general eommittee to go into Penna. He is very strong there. I fear we have negleeted the soldiers too mueh. It seems to me that some military exhibition on our side is the only thing to be done before the Penna. elections. If it is made a 'reception' of these generals it cannot be a failure, as there will be a great turn-out to see them. General Slocum should also be there. He can give aid in getting up the movement.

$$
\begin{aligned}
& \text { "Truly yours, \&e., } \\
& \text { "Horatio Seymour." }
\end{aligned}
$$

\section{HORATIO SEYMOUR TO TILDEN}

"UTica, October 2, 1868.

"Mr dEAR Sir,-I send you a letter from General Franklin which is very gratifying. I have written to him, urging him to go to Penna. He is a distinguished soldier, I think from that State, and a great number of those who served under him live there. As he is unused to public speaking, some good talker, who is a man of eharacter, should go with him.

"I have written to Genl. MeClellan, asking him to go to Penna. I felt a delicacy in doing so, but the necessity is so great that I sent him the request by Mr. Mather. It will do us great harm if he declines. Our people have looked for his return with anxiety. He has more power in Penna. than any living man. This I learned when I spoke there in 1864. His visit will wipe out the effeet of the soldiers' convention. As he was with me when Penna. was invaded, 


\section{LETTERS AND MEMORIALS' OF SAMUEL J. THLDEN}

he can do me much good. I did not feel I could in my letter to him say as much as I felt. The soldiers are not inclined to go for Grant. Ile slanghtered them too ruthlessly. With many thousands of them McClellan's words will be words of command. All nyy letters from Pema. say that his visit is the only thing needed before their alection.

$$
\text { "Truly yours, \&c., }
$$

"I hope the committee will urge Genl. Franklin to go to Penna."

\section{S. J. TILDEN-RECEIPT}

“New York, Oct. 4th, 1868.

"Received of Allan MeLane, Escl., two humdred and fifty thousand dollars $(\$ 250,000.00)$, the same being onehalf the purchase money for the steamer Oregonian, sold by W. H. Webb, Esq., to the said Allan MeLane for the sum of five hundred thousand dollars, and conveyed by bill of sale to me, the undersigned Samuel J. Tilden, in trust for the said Allan McLane, and to be by me transferred to the Pacific Mail Stean Ship Co., on whose aceount the aforesaid purcliase of the said steamer Oregonitn was made by the said Allan MeLane, the conveyance aforesaid to be made by me, when requested by the said MeLane and upon the payment of the balance of the said purchase money, to wit., the further sum of two hundred and fifty thonsand dollars. "(Sighed) Simiı. J. Tilden."

\section{WIXFIELD S. IIANCOCK TO TILDEN \\ "Carondelet, St. Louis Co., Mo., Oetober 10, 1868.}

"Hox. S. J. 'Thubex, New York.

"My dear Sin,-Your favor withont date, enclosing me a note written to you by Governor Seymonr, was received last evening.

"The Governor's letter is very delieate, kind, and considerate.

"I have been confinerl to $m y$ room since the 10 th of September, and in that time to my bed until within the last few lays. I am far from well now. My wound, which had closed after opening, threatens to reopen. It may not do 
so immediately, but I presume it is but a question of time, as it had been allowed to close too soon.

"It will be many days, probably weeks, before I shall be in condition for any effort.

"I am a member of the 'Dyer' court of inquiry, which has been postponed from week to week on account of my absence. So soon as I am able to endure the fatigue of travel I shall be compelled to go to Washington on that service.

"I had always believed that it was not well for officers of the army to engage actively in political campaigns, and I had concluded so long as I remained in the army not to set a contrary example to younger officers; still, the crisis is of such vital moment that I might probably have acted differently in the particular case urged by you, especially when possibly our eventual success depends upon the action of my own State in October. But neither time nor health permit me to act. It is therefore not necessary to discuss the question.

"I believe the election next Tuesday will decide the result of the Presidential election if the majorities in the States are at all positive.

"Our carrying two of the three will insure us a victory in November.

"I feel great interest in the result, I believe no person more so than myself.

"It is our only and last chance. "I am, Truly Yours,

"WiNFd. S. HaNCOCK."

S. J. TILDEN, AUgustus schell, AND AUgUST BelmoNT TO W. F. STORY (TELEGRAM)

“ New York, October 1\%th, 1868.

"W. F. Story, Chicago, Illinois :

"Telegram just received. The suggestion made to change ticket was wholly unauthorized and unknown to National Democratic Executive Committee or any member thereof. The proposition is regarded as absurd, and is received by our masses with astonishment, derision, and indignation. In October elections we gained largely on much increased vote, compared with cighteen sixty-six, and nearly carried 
Pennsylvania and Indiana. Been overborne only by sy'stematic frands and rejection of votes of citizens of Irish and German birth by party that elaim suffrage for negroes as national right, and practically aceords him supremacy over white men. We came nearer to our expectations than Republieans to theirs. If our firiends continue contest in all States with same vigor, our foes will find it impossible to spread their resourees over so vast an area with equal effect. Our masses are resolved to renew eontest mnder our chosen leaders, with our old flag flying, with organization unbroken, and with two and half million voters compact and always ready to rally for resene of constitutional government and eivil liberty.

$$
\begin{aligned}
& \text { "S. J. Tilden, } \\
& \text { "August Belaiont, } \\
& \text { "Augustus Scinell." }
\end{aligned}
$$

TILDEN TO FRANCIS P. BLAIR, SEN. (TELEGRAM)

"Francis P. Blair, Sen.

Washington, D. C.

"Without contemplating any change, I should be glad to consult with you, but can't leave my post. Come here immediately if you can.

"Nww York, Oct. 20, 1868."

"S. J. Tillden.

\section{TILdeN TO AUGUSTUS SCHELl (TELEgRAM)}

"IIox. Augustus Scinell, Utica.

"NEW YoRK, Oct. 21, 1868.

" IIad conference with Spencer and others, and on reflection eonclude that we can't spare you possibly. You nust come back to the helm with me and provide other companionship for our leader. Cone to-night. Can't explain further.

"S. J. Tilden."

SANDFORD E. CIIURCII TO TILDEN

“ Rochester, Dec. 2d, 1868.

"Mr dear Sir,-I suppose the St. Paul preferred was not purchased. I am sorry that it was not, beeause I see that you was right about the andvance. 
"I see that the Eric fight is in a great muddle and growing worse.

"I have been thinking' of a project for" my own benefit, and that is to have all the parties compromise upon me for receiver. I suppose that Behmont on one side, and Tweed and Sweeny on the other, might control it. I would deal fairly by all, and the Erie people might be assured of that, while Davies would be content to have the law business. It would enable me to make some noney, and be a good thing all around. I thought I would suggest it to you in strict confidence, and if you can accomplish it I feel sure it will be for your interest, and I will make it so. If you think anything of this act accordingly; if not, burn it, and say nothing about this, attributing it to a weakness to make some money.

Truly yours,

$$
\text { "S. E. Cirurch." }
$$

In the first volume of my Life of Tilden (page 226) I had oceasion to refer to some of his reasons for declining to withdraw from his candidacy for Governor in favor of Mr. Chureh. The statements there made gave offence to some of Mrr. Church's political followers, which found expression in one of the most devoted newspaper organs of the Canal Ring in Syracuse. In the preceding letter from $\mathrm{Mr}$. Chureh the reader will find some additional justification for the opinions above referred to, and which helped to inspire Mr. Tilden's distrust of Mr. Church as a leader of a party for reform.

\section{TILDEN TO COMMITTEE OF ALBANY BAR}

"New YoRK, Dec. 25th, 1868.

"Gentlemen,-I regret that I shall be mable to be in Albany to-morrow at the meeting of the Bar, which you have invited me to attend, and which is to be held for the purpose of 'taking' appropriate action in regard to the death of ou' esteemed friend and professional associate, Peter Cagger.'

"T should, however, do injustice to my own sentiments if I did not avail myself of the opportmity to join my expressions with yours of our common sense of the personal and public bereavement which is the oceasion of your meeting, and of the esteem and affection with which we regarded 
our lamented associate and friend, while living, and with which we still cherish his menory.

"I hope that sone one of those who best knew Mr. Cagger will make an enduring record-not nerely of the frank and genial and hearty natme which beamed upon us all; not merely of lis eharacteristies as a citizen, a friend and a man, which are known to everybody ; not merely, even, of that remarkable executive ability which he manifested in his profession, in business, and in the broader relations with men in which he acted so important a part, but of his great modereloped capacities as a lawyer and a public man, which were evident to those who saw him intimately and were only kept from the public view by his mambitions temper, which deferred to others and voluntarily limited his own sphere of action.

"With great respect, gentlemen, I remain, "Very truly yours, "S. J. Tilden."

CII. O'CONOR TO S. J. TILDEN

“ N. Y., Nov. 11, 1869.

" Mr DE.Ar Sin,-T am so pressed for time that I do not know that I shall be able to find a printed copy of the opinions read in the Legislature of New Jersey on the motion to rescind the assent of the 14th Amendment.

"They were three in number, I think: one by Reverdy Johnson, one by George T. Curtis, and one by me. If it should become desirable to use any of them they can readily be found in any file of a Denocratic paper.

"Should mine be deemed worth using, I should like to have a correction malle.

"By way of emphasis I italicized the word when. This is printed where in all the copies I have seen; and to render the pointlessness of my expression as striking as I desired to render its point, "where' is sometimes italicized and sometimes put in small caps.

"If you should have any part in using" or printing this paper, I am sure you will see this error corrected.

"It is molerstood that the 14 th Amendment is past revocation now, as the requisite number' of States have consented. The consent of sereral were forced, and if the Democratic 
party is to live in the future it will deny the efficacy of such extorted consents.

"I mention this to the end that you may consider whether the consent of $\mathrm{X}$. $\mathrm{Y}$. to the 14 th should not even now be rescinded. Of course, that question has more in it than the inquiry as to the 15th Amt.

"Y'rs truly and in haste,

"CH. O'Coxor."

JOHN SHERMAN TO S. J. TILDEN

(CIRCUlar to THE BONDHOLDERS OF PITTSBURG, FORT WAYNE \& CHICAGO RAILWAY CO.)

“Mansfield, Ohio, Oct. 20, '69.

"MY DEar Sir,-I have just read over, in the quiet of my study, your admirable circular to the bondholders, etc., of the P., F. W. \& C. R. R. Co. I cannot forego the expression of my appreciation of the clearness and ability of this statement. It exactly defines the reciprocal duties and rights of the owners of a railroad and the public at large, and states in as few words as possible the reasons for the lease. I do not believe we will soon have occasion to regret it, and sure I am you need not be ashamed of your "statement of the case.'

I am, truly Yours, "John Sirerman."

\section{TILDEN TO RICIIARD VAUX}

"Confidential.

New York, Oct. $\%, ' 69$.

" Mr DEAR Sir,-Returning home to-day, I find your letter of the 4 th.

"It is difficult to obtain the funds necessary for the most economical conduct of our State canvass, especially as we have no candidate who is wealthy. We expect to fight the 'poor man's' battle, but expect to fight it successfully; at present the committee has no funds, and is going on credit of its expectations, which are small, but, we believe, sufficient. I do not think it probable that money conld be raised in this city to send abroad. The number of contributors is small, usually, and there is now not much political excitement.

Very truly yours,

"Richd. Vaux,

$$
\text { "S. J. Tildex. }
$$

"520 Walnut St., Phila., Pa." 
"Mr DEsR Sir,- At the suggestion of a friend of Mr. Russell Sage and of mine, I should attend on 'Tuesday next in the Orer and Terminer if I were not obliged to leave town early to-morrow norning on business which will probably make it impracticable for me to return in season.

"Under these ciremunstances I beg leave to say to your learers as if upon that oceasion sone part of what I should say if present.

"I think there ean be no doubt that all the grounds of the discrinination eontemplated against Mr. Sage, as compared with the other persons charged with having reeeived more than seven per cent. for the use of money-as those grounds are reported in the public journals-are erroneous in point of fact.

"The prineipal ground is the supposed participation of Mr. Sage in the locking up of greenbacks. This allegation is denied in the most positive and eomprehensive manner by an affidavit of Mr. Sage. That denial is corroborated by affidavits of one or more persons most intimately acquainted [with] his affairs. I find no diffieulty in giving full eredenee to these denials from $m y$ own knowledge of Mr. Sage, his methods and habits of business, his transactions and investments. They are all incompatible with his being engaged in any such scheme. I have known him well for years. He is about the last man to enter into any combination which would limit the freedom of his individual and personal action. IIe is not a lender of money as a business or otherwise than of his temporary balances. His interests are all in favor of elevating rather than of depressing stocks, in which the bulk of lis property is invested. It would not need the affirmative proof whicli is offered to make me totally diseredit the representation that he was or could be involved in a combination of the character and objects imputed to him. Mr. Sage is a man of rare ability, energy, and enterprise; and his use of these powers is all in the way of building up, constructing, devoloping. I am satisfied that there is not the sliglitest ground for imputing to Mr. Sage anything beyond the mere fact of receiving more than seven per cent. for the nse of money. I hope that you will ensider it consistent with your duty to confine your 
sentence to the fine which you have applied to the other - cases of the same character; and I am sure the judgment of the bar and of the entire community will sanction such a disposition of the case.

"It is not necessary, in my view of the matter, to discuss the statute of 1837. It was peculiar in two respects: that it reversed the equity rule which had prevailed always before in this State and in England, that in cases of usury ' he who seeks equity must do equity'; and that it added to the forfeiture at law of the money loaned a criminal penalty. I remember it in its origin, its anthorship, and the cireumstances under which it rame into being. It was then deemed an extravagant and barbarous law. I have never known its criminal feature enforced until now. I presume that nearly all the community, as well as Mr. Sage, were ignorant of the existence of a feature so anomalous in all jurisprudence.

"I beg to add that the case cannot be deemed one calling for any exceptional rigor; nor do any eircumstances of aggravation exist to justify the infliction of a special indignity upon a man of character like Mr. Sage, doing an act, not malum in se, universally practised and universally tolerated.

"With much respect,

"Hon. Albert Cardozo."

$$
\begin{aligned}
& \text { "I remain, } \\
& \text { "Truly y'rs, "S. J. Tilden. }
\end{aligned}
$$

\section{S. E. CIIURCH TO S. J. TILDEN}

"Hon. Saml. J. Tildden.

" Rochester, June 2\%, 1869.

"My denR Sir,-Your favor is reed. I was sorry you was not at home when I called, although I had no specific business. But it is a good thing to have a general talk once in a while to see whether we look at things alike. Polities seem to be drifting just now, but I think the general tendency of public opinion is in our favor, and at the end of four years we shall go in as a matter of necessity. As to investments - I have precious little to invest, but I would be glad of an opportumity to make some money, and if you see any good chance I hope you will let me know.

"Are you not coming up this way this summer? We 256 
would all be glad to see you and any of your family that ean come with you.

$$
\text { "Truly Yours, }
$$

S. E. CHIULCII TO TILDEN

(WOULD LIKE TO MAKE SOIL MONEY)

"Rochester, Jan. 2\%, ' $\%$.

"Mr deak Sir,-This is my first letter" written by myself. Yon inquire what my physician thinks and what I think about my recovery. My physician and others who have been consulted all say that my recovery is eertain and will be perfect, restoring me to full health, but that it will require time on account of my great prostration.

"I have had the 'blues' oceasionally, but I believe I shall recover and be well. I am confined to my bed most of the time, but am able to sit up some and walk a little.

"I would like to make some money. Is there not some speculation by which I ean do so?

"Why don't you get interviewed?

"Please write.

"Yours truly, "S. E. Church."

TILDEN TO T. P. BISSELL

"New York, Jany. 10, $18 \% 0$.

"Mr dear Sir,-Can yon furnish me the following information:

"1. Copy of the record of births, deaths, and marriages in the family of Isaac Tilden or any others of the name of Tilden, as shown in your office.

"2. Memorandum of the names of parties, dates, and substance of deeds and mortgages to and from the said Isaac Tilden and others of the name of Tilden.

"If these are very numerous, a brief memorandum will answer.

"I can decide afterwards whether I will want eopies, and, if so, what.

"3. How can access be got to the church records, and can you get the information from those records as to the matter's embraced mider No. 1? 
" 4 . Where is the probate office in which wills were kept from 1702 to 1760 or 1780 ?

"Can you look for will of Isaac Tilden conveniently?

"Of course, I will give you a reasonable compensation for any trouble you may be at in procuring and sending me the information mentioned above.

"Truly yours,

"S. J. Tilden.

"Hon. T. P. Bissell, Esq.,

"Hebron, Conn."

JAY GOUI.D TO S. J. TILDEN

"President's Office, Erie Railuay Company, cor. Sth Ave. and $23 d$ St. "S. J. Tillden, Esq.

"New York, F'eb. 11, 1870.

"Dr. Sir,-Feb. 24, 1869, I paid you retainer for Erie R. R. Co. $\$ 10,000$. Subsequently, on March 5, at your request, I bought Flagg's bonds, with the understanding that he will eo-operate with us in A and G matters, paying him $\$ 3038.29 / 100$, being the face of the bonds and accrued interest, compounded. At the same time that I paid you the $\$ 10,000$ I paid you also $\$ 1000$ for Flagg's services to date as trustee, for which vou returned me voucher signed by A. C. Flagg for his daughter.

"I wish to ask you whether, in view of the foregoing, we are not justified in being surprised to find you against us without notice?

"Please reply and oblige,

"Yours truly,

"JAY Gould."

\section{TILDEN TO JAY GOULD}

“Monday Evenivg, Fcbruary 1/, 18\%0.

"MY DEAR SiR,-On my return late Saturday night I received yours of the 11th, and I take the earliest time at my disposal to reply.

" The retainer to which you allude grew out of and related to matters wholly distinet and disconnected from the A. and G. W.,* and was arranged without any agency of mine, and the subsequent payment of it was purely voluntary on your part.

* Atlantic \& Great Western Railroad. 
"No intination was ever made to me that it had any reference to or was to affect my relations to Mr. Flagg* as trustee under the several mortgages of the $A$. and G. WV.

"I camnot doubt that it was known to you that I had acted as lis counsel for more than a year previous. Nor did I ever suspect that you did not perfectly understand that I was still at liberty to do so.

"Afterwards, when Mr. MeHenry† sought to retain me in reference to his scheme for reorganizing the $\Lambda$. and $G$. W., and asked me to name the amount-having looked into all the relations of parties, and having considered his plan -I declined to have anything to do with it in any manner or for any purpose, and refused his retainer, repeatedly pressed upon me.

"In one of these interviews I informed him that the suits which had been commenced to foreclose the mortgages, if, as I understood them to be, for I had not seen the papers, were objectionable, that, if a sale were to be had, they must be reformed or abandoned, and new suit in proper form, and with proper parties, instituted; that Mr. Flagg-at the instance of any bondliolders, and possibly in an extreme case without their instance-ought to intervene for that purpose. To this view he yielded.

"When the lease proposed to be made by the receiver was brought to my attention some wecks ago, the counsel of the Erie called on me to ask my consideration of it as counsel for Mr. Flagg and of the first mortgage bondholders. He called on me to exercise my function in that eapacity; and had prolonged negotiations with me, not as an associate, but as a representative of a different party.

"I heard no complaint until it happened that, while acting as counsel for the trustees and bondholders, I did not do preeisely what their adversaries preferred to have done.

"Now, I answer your question: You 'are not justified in being surprised that I am acting for the trustee and his bondholders "without notice", to you. You had notice all the time that $I$ was at liberty so to act, and much of the time that I was so acting. If you are surprised, you are under some misapprehension as to the situation. I would have omitted no courtesy towards you. I had no suspicion

* Hon. Azariah C. Flagg, former comptroller both of the State and late of the eity of New York.

f James Mcilenry, the promoter of the Atlantic \& Great Western. 
that you did not understand my position exactly as I understand it.

"When the question as to the proposed lease came before me, suddenly and unexpectedly, it was with the declaration of Mr. Meyer that he was 'opposed to it, unless I could show him leasons to the contrary, which he did not think I could.' I looked at it to see if I could devise modifications which would make it safe for the bondholders.

"The difficulty of the case is the short and uncertain duration of the lease. I was not able to see in it, as drawn, sufficient guards to satisfy the bondholders. I spent a morning with Mr. Lane and Mr. Meyer discussing amendments; and we left for Ohio, with the understanding between him and us that we should have a conference there upon the subject of amendment. It was only when the motion was on and the argument was about beginning that we learned to our surprise that Mr. Backus had decided that no negotiation for any modification would be entertained. So the question had to be argued as it stood. Just before I left Cleveland, Mr. Backus said to me that if we would recognize the advance $(\$ 1,390,000)$ as to be ultimately paid, he would do everything to give us security in the operation of the lease; and, if, when I got to New York, it was thought advisable to negotiate, he would come here on your request. After my return I did think it advisable to consider the question, and so said to MIr. Lane; but he declined. Shortly after, the motion in Philadelphia, of which Mr. Cuyler had given notice, in pursuance of a reservation he had caused to be made in the original order, came on.

"I allude to these circumstances to show that I have treated you fairly and considerately while in an adversary position on this question of temporary lease.

"One word as to Mr. Flagg. The payment of the $\$ 1000$ for his services was due him, and should have been provided for. I first called the attention of Col. Stebbins to it, and then yours. The purchase of the bonds of Mr. Flagg-to a trifling amount-was no greater favor than had been accorded on a large scale to parties who had stood in the way of the arrangement for the close of the receivership and the making of the lease. That he had taken no selfish care for himself did not seem any reason why he should be treated with less consideration. I submitted the matter to you as the proper party. You treated it with equity and courtesy. 
You are entitled to the same spirit from Mr. Flages. But you could not have supposed that he would be unfaithful in any respeet to his trust.

"In conclusion, what the first mortgage bondholders want is :

"1. That the suit for foreclosure should be prosecuted, in proper form and with proper parties, to give a good title at the sale, and that they be represented in these suits by their own agent and not by agents of any adversary party.

" 2 . That, if a sale and purchase of the property be made which operates to discharge their lien, with or without an agreement for reorganization, the title be taken by satisfactory agents for their security.

"That in the mean time the property be protected and further debts in priority to their rights be avoided.

"With these conditions observed, the first mortgage bondholders have every desire to preserve the best relations with the Erie, which is the natural and preferred connection. That is my advice. That is their disposition.

"If you wish any conference on the points on which differenees have arisen as to the proposed lease, or as to the general relations of the two roads, I shall be happy to obtain an appointment for that purpose.

"In ny judgment the faculties of the parties would be better employed in devising a eomplete and permanent harmony of interests than in litigation. I think, also, that to attempt to diseard from the negotiations the divisional bonds which represent most of the value in the property is a praetical mistake.

$$
\text { "Very respectfully, Yours, \&e., "S. J. 'Timden. }
$$

"To Jay Gould, Esq."

\section{JAY GOULD TO TILDEN}

"New York, Feb. 21, 1870.

"Dr. Srr,-I am in receipt of your note on the subject of the retainer of $\$ 10,000$ paid yon by this Co. I can only say that it was mderstood and treated by the company as a general retainer, and the voucher so states. The only matters I have consulted you in reference to have been $\dot{\Lambda}$. and G. W. matters. Knowing the pressure of your other engagements, I felt like troubling you as little as possible, and 
I therefore simply said to Mr. Lane to consult you if necessary, but to trouble you as little as possible. The reason I conld not consent to Mr. McHenry giving you a retainer was the fear that his interests and ours would clash, as I did not have confidence in his schemes.

$$
\begin{aligned}
& \text { "Yours, } \\
& \text { "JAY Gould. }
\end{aligned}
$$

"P. S.-I shall be happy to meet the other parties on the subject of an arrangement at any time.

"J. G."

TILDEN-CIRCULAR OF THE STATE COMMITTEE

"New YoRK, April 15th, $18 \%$.

"Mr DEAR Srr,-The election of a chief judge and six associate judges of the Court of Appeals-which will take place on the 17th of May-and the nomination, at the Democratic State Convention to be held at Rochester on the 27 th of April, of our candidates for the chief judge and four of the six associate judges, are events of great interest.

"The Democratic party has never hitherto failed to supply in the court of last resort judges of undoubted moral and official purity and integrity, who have commanded the confidence and reverence of the whole people, and who have, by their abilities and professional learning, illustrated the jurisprudence of our State and country.

"In the present tendency of our times-towards a weakening of the trust of the people in the judiciary-it is more than ever important that we hold our standard of character and qualifications high.

" $\mathrm{A}$ degradation of the administration of justice is the last calamity of a republic.

"Distrust or doubt in the public mind as to the administration of justice, even if unfounded, involves half the evils of an actual degradation.

"At this moment-when we are about to form our highest court, entirely ancw, and for a long period-it is our duty to give attention to the subject, to withdraw ourselves for a little time from our private avocations in order to fulfil our highest obligations as citizens of a republic.

"First, special care ought to be exercised that our most wise, discreet, and disinterested men be chosen to, and be 262 
indueed to attend, the nominating eonvention at Rochester on the 27 th.

"They should come there to confer for the public good, in a spirit of harmony, conciliation, and surrender of all personal prejuclices and all personal antipathies to the great object of forming absolutely the best ticket possible.

"Secondly, assuming-as we may, with eonfidenee-that we shall so act at the convention as to start our canvass with the farorable opinion of the public and of the bar of the State, still in a special election held at an unusual time, and in so short a eanvass, prompt and effieient measures slould be taken in each eounty to organize a movement to bring out our vote and elect our ticket.

"I ask your co-operation for these objects. "Very truly yours, "S. J. Tilden."

TILDEN TO IION. S. E. CHURCII

\section{"Confidential.}

“NEw Yonk, April 20, ’\%o.

"Mr DEAr Sir,-My letter, which passed yours in the mails, if I recollect its contents aright, is, or implies a practical answer to your last, so far as we ean see until we meet in Rochester. I have trusted to it for a day or two, while I am engrossed with measures not eapable of being deferred, and which seem essential to the eonvention and election.

"As to candidates, I have carefully kept mrself free; saying uniformly-in quite a number of eases where communications have been made to me personally or by letter -that I intended to be perfeetly and absolutely open when opportunity should be liad, at the convention and just before, for consultation with our friends to do what might seem best. I am not eommitted to Comstock, unless it be implied that I would not decide against him until that time, from such expressions made to him and to others.

"He, undoubtedly, has eounted on the nomination as chief judge; las beliered that Allen was for him, and only aimed to be associated with lim.

"While I have kept more cantionsly free than Kernan and others, I wish to treat Comstock with delieacy and kindness. Indeed, as I look upon my own future, totally void of any conscious desire for the most honorable of offieial 
labors, it seems to me I feel more difficulty in woundingany more than I at last must-those who are eapable of fixing strong affections on objects of an elevated ambition.

"I need not say how strong-and stronger than in other cases-is the personal interest I feel in promoting what shall be finally agreed to be best in respect to your future eareer, or how disposed I should be to give the prevailing weight to your own ideas on that subject.

"While it is not safe to assume the action of a convention, I should think that besides those who will go for you on publie grounds and from personal regard, there will be an element which would like to remove you from the field of active politics. I thought, from December to very recently, this was visible in respect to me, and perhaps there may be even greater motive in respeet to you in that you were more likely to become a rival to some existing powers.

"Before I had quite finished my note, which lay over from last evening, yours of yesterday eame.

"You perhaps interpret it rather more strongly than I intended. I aimed only to suggest the topic, and naturally stated the cons rather than the pros.

"I will endeavor to see you, as you suggest, at Albion, before the eonvention, unless something happens to make this inadvisable.

"And letter-writing is so insufficient for such topics that I reserve the discussion till then.

"Meantime, consider what is the method of proceeding in nominating the four. Is that to be done singly, or on one ballot?

$$
\begin{aligned}
& \text { "In haste, } \\
& \text { "Yours truly, "S. J. Tilden. }
\end{aligned}
$$

"Hon. S. E. Church.

"Make my special regards to Mrrs. and Miss Church."

\section{S. E. CIIURCH TO TILDEN}

\section{"Albion, April 20, $18 \% 0$.}

"Mr denR Sir,-Your kind favor reeeived. I infer that you are opposed to my taking a nomination for ehief judge, and it is quite likely you are right about it; but $I$ feel that there has been a great break in my life, and that it may be as well to start on a new track. My reputation is now fair, 
and on the bench I can keep it so, mutil I want to use it for my own benefit and that of my friends, and I think I can aid you politically as much as I can to remain as I am. I shall, of comrse, object to being regarded as 'shelved' by the operation, and yet such may be the result, and some people will doubtless firor my nomination for that reason. They may be awfully mistrlien, but this is confidential.

"I shall not dare to go to Rochester next week, lest the excitement might produce a relapse; but you nust come here and see me the day before the convention, which you can easily do, and then we ean talk the whole thing upas you say, it camnot be written. Don't fail to come. "Truly yours,

"S. E. Churcir.

"Mrs. C. and Nellie send regards."

\section{TILDEN TO JOIIN R. REID}

"New York, Apl. 21, 1870.

"MY DEAr Sir,-I am obliged by the kind terms of your note of yesterday, which were also repeated to me by $\mathrm{Mr}$. Frost, who called on me. But I do not change the feelings with which I regard the nomination for the ehief judge, and have regarded it since it was presented to my view in December, or weakened the settled preference I have for freedom and relaxation over even such an honorable distinction. Notwithstanding such a definitive purpose on my part, I hope that you will take care to send a good delegate, beeause you and I will probably never have another chance of doing so much service to the community in which we live, or to the profession to which we belong, as in securing the best possible selection for judge of the judicial court under a comparatively permanent temure.

$$
\begin{aligned}
& \text { "Very Truly, } \\
& \text { "Yours, \&e., } \\
&
\end{aligned}
$$

\section{TILDEN TO IION. JOIIN GANSON}

“NEW YonK, Apl. 22nd, 'Yo.

"Mr DEAR Sin,-I shall regret it extremely if you cannot extricate yourself from the embarrassments which you mention and $\mathrm{I}$ appreciate; and yet come to the convention, 
if not as a delegate, at least as an outsidcr. Such an occasion will not be likely to occur in your time or mine, and ought we not seize it to do something of real value to our four millions of people and to pay the debt which Lord Coke says a lawyer owes to his profession?

"I have often thought and talked of you as eminently suitable to take a part in the reconstructed court, but have heard that you were not ready to sacrifice the large gains of your professional career. You are over-morlest in the suggestion of one or two friends desiring you to come to a different conclusion; for I have talked with a large number who looked to you, and whose motives cannot be imputed as mere friendship, but spring from a sense of public utility, in sceuring to the public service your abilities and independent integrity. Indeed, Grover told me some time ago that he would not be a candidate if you would be; and I think the same concession would have been generally made, at least at an earlier day.

"With respect to myself, I cannot reconeile myself to the idea of being tied up for a series of years. I prefer freedom and a period of relaxation to any honors which involve permanent and laborious duties. In December, and repeatedly sinee, the suggestion from Albany has been made to me that I might have a general support from that and this part of the State for chief, in which those not supposed to be the most friendly would coneur, and a considerable number of similar tenders have come to me from other quarters; but to all, by letter and verbally, and among others to Cassidy, each, and Allen-and to Comstock, who is an affirmatively [sic] candidate, to Kernan and O'Conor-I have stated my purpose, and I have no disposition to change it. It is not that I undervalue these great trusts, but I am content that they go to those to whose more robust natures and physical vigor the same considerations which influence me are not applicable, and to those in whose peculiar condition they are an object of laudable ambition. If I can help to get a good selection, and then to elect the ticket, I shall consider myself as concentrating in a few days all the public service I could perform in the whole 14 years; and so having completely acquitted myself to my day and generation, become entitled to a play spell.

"Now, my dear sir, it is in just this matter that I regret to lose your co-operation. You, if present as a delegate or 
as an outsider, could lielp largely in the seleetion of members from all parts of the State. For this eity-if the bar were to control as it now stands-they would mite on Rappallo, but whether he ean get any political support or not remains to be seen. IIe has been one of Vanderbilt's counsel, but I have often put him with you when I have said that, with the lest quality of men, that consideration could be wholly disregarded.

"Can you extricate yourself from the embarrassments to which you allude-or be nentral on that case-and come and help as to others?

"Remember that for your time as well as mine this oceasion is not likely to recur.

"I sat down to say this, and must beg you to exeuse me for the long letter I have poured ont upon you.

$$
\begin{aligned}
& \text { "Very Truly, } \\
& \text { "Yours, \&e., "S. J. TildDen. }
\end{aligned}
$$

"I have omitted to speak of Churcl. If he becomes a candidate, as is probable, thongh not deeided, he will be a strong one before the convention."

\section{TILDEN TO GEORGE W. CASS}

(JAY GOULD'S RETAINER)

"New York, June 2d, $18 \%$.

"Mr DEar Sir,-You will recollect that some time ago I requested you to give me a statement in respect to the circumstances attending an arrangement communicated to me by you in the winter of 1869 , by which the Erie Railway Company paid me a retainer of $\$ 10,000$ in connection with the Cleveland and Pittsburg Railroad Company, a majority of the stock of which was then owned by the Erie Railway Company. You deferred it, in consequence of the pressure upon time. I should now like to have you furnish me the statement.

"The reason I applied to you was that my original information as to the purposes of this retainer was derived exclusively from you; and that it was under this information, in no respect changed by anything derived from other somrees, that I accepted the payment. 'The facts, so far as 267 
they are within my knowledge, are these: Early in $1869-$ I presume it must have been in Jannary of that year-yon asked me to consent to become a director of the Cleveland and Pittsburg Railroad Company and a member of the executive committee of that company, holding the balance of power between the other two members in case of their disagreement. Yon stated the object to be to make an amiable arrangement between the parties then litigating in an Ohio court, whereby the railroad conld be taken out of the possession of the receiver and restored to the management of the company; and that as a part of the same compromise yon were to become a director with others who were to be agreed upon. You will remember that I replied that I was already burdened with work in the capacity of director in other companies, which consumed an inconvenient share of my time and thought, and withont remuneration; that the tendency of such work was to become more encroaching; that I had entered upon it in every instance only under the inflnence of existing relations, and was desirous to relieve myself of snch duties as I had already done in some cases; and that $I$ was unwilling to take such a trust in respect to a company in which I had no interest, and had never had any relations. You and $\mathrm{Mr}$. MeCullough repeatedly pressed me not to positively refuse; and when I was elected it was without any assent on my part. One day you mentioned to me that Mr. Jay Gould had proposed that the Erie should pay me $\$ 10,000$, the Cleveland and Pittshurg $\$ 5000$, and the Fort Wayne $\$ 5000$. I certainly understood that those payments were proposed to be made in respect to services or benefits expected in connected with the arrangement for the change in the condition and management of the Cleveland and Pittsburg Company, and nothing else. Your communication related to that matter and to that alone. You will remember that when you mentioned the proposal to me I made no comment, and manifested no interest in it or desire that it should be adopted. Afterwards, when $\mathrm{Mr}$. Gould mentioned the matter to me he made no further or different explanation, but spoke of it as if it were a matter which I already completely understood. He subsequently, a second time, mentioned that he was going to send me a eheck, and about the last of February did send it. I never did or said anything about the matter except to accept and receipt for the check. The Cleveland and Pittsburg Com- 
pany, at a meeting when I was not present, but believe you were, adopted a resolution appointing me their comsel, with a monthly salary at the rate of $\$ 5000$ a year. I had supposed they would have put it in one parment, but they adopted such form as they pleased. 'The Fort Wayne never mentioned the subjeet to me, nor I to it. I had relations to it, but none to the Cleveland and Pittsburg or to the Erie. The proposition to make the payments by those two companies was purely their own; the amounts were fixed without any eonsultation with me, and on their own estimate of the utility of the arrangement to them. In expressing to you my repugnance to undertaking the services, I did not eontemplate any condition as to pecumiary compensation. Nor ean I now say that any such consideration was a principal inducement to my aiding in the trust. I could not foresee how much of labor or trouble I was to mudertake. I did not desire more business, but less. I had during the two years before repeatedly declined retainers from the Erie and from its adversaries. The object of the arrangement was attained. The receivership was closed and the administration of the road was restored to the Cleveland and Pittsburg Company. I served out my term as director, as member of the executive conmmittee, and as counsel of the company, and gave every neeessary attention to those duties. When this was done I deemed that I had performed all I had undertaken, and that the C. and P. and the Erie had realized all they had contemplated in the arrangement which they had proposed, and in the payments which they had voluntarily made.

"It was not until in February last, when I was acting for the trustees of the bondholders of the Atlantic and Great Western Railway Company, that I learned with surprise that Mr. Gonlds entertained the idea that the implied engagement in accepting the retainer before mentioned extended leyond the atfair of the Cleveland and Pittsburg, to which the arrangement exclusively related. I answered him at the time. But the eircumstance that he did entertain such an idea induces ne to address you this letter.

"With much respect,

"Yours very truly,

"S. J. Tilden.

"Hon. George IT. Cass." 
MR. TILDEN'S PURCHASE OF TOPIC

"June 10, 'ซo.

"I have this day sold to Samuel J. Tilden a bay horse gelding called Topic, six years old, for fifteen hundred dollars; and I hereby warrant the said horse to be sound and serviceable in every particular, and to be kind and gentle in use under the saddle and in single and double harness; and I do further agree that such sale is made on the following special conditions: first, I agree that if the said horse, after he shall have been used, shall not in all respects suit the said Tilden, I will, upon notice at any time within one year from this date, take back the said horse Topic, and return the said purchase money, but without interest; secondly, if the said Tilden shall prefer I will give to him in exchange for Topic any horse which I may bring to New York for market within the year, on fair and reasonable terms of exchange, provided that the said horse Topic shall be fairly treated by the said Tilden in the mean time, and shall be also at the risk of the said Tilden in respect to accidental injuries, and that the delivery of the said horse Topic, in return or exchange, shall not be required before April first, 1871. In witness whereof I have set my hand and seal this 10th of June, 1870.

"Witness, Geo. W. Smith."

"Logan Railey.

SAML. G. COURTNEY TO S. J. TILDEN

"Strictly private.

"SUNDAY, 51/2 P.M.

"Mr dear Tilden,-I regret to inform you that there is a great deal of bad feeling abroad among our friends respecting the arrest of Connolly, and you and Mr. Havemeyer are blamed and denounced for it, and for deserting him in the hour of his need.

Of course, as far as you are concerned, the sentiment I speak of is baseless and unfounded, and I have endeavored to set you right, and I think have succeeded; but as to Mrr.

* For an account of this grievance of Mr. Connolly and his relations with the Tweed ring and with Mr. Tilden, see Bigelow's Life of Tilden, Vol. I., pp. 182-210. 
II., there is but one feeling, and that of universal condentnation.

Mr. Connolly is still in duress, and I am afraid he camnot get the required bail. What's to be done?

I mean to stand by him and sustain him now, for under my advice (together with the urgent appeals of Mr. H.) lie resigned, and the result is imprisomment; and as Mr. Peckham says on his affidavit, they were awaiting only his resignation to aceomplish what has been done.

"I write this to you in strict confidence.

"I think you ought to know what is going on. I am jour true friend, and do not intend to have you placed in a false position.

"I am going to New York Hotel (room 131), where Connolly is. Unless you see some insuperable objection, I think you ought to call this morning and see him.

"Truly yours,

"IIon. S. J. Tilden.

Siml. G. Courtney."

\section{EVILS OF OUR TIMES}

(ENDORSED “ DRAFT OF CIRCULAR," ALL IN TILDEN'S SCRIPT)

"Centralism in the government, and corruption in administration are the twin evils of our times. They threaten with swift destruction eivil liberty and the whole fabric of our free institutions.

\section{"National Government.}

"The Democratic party was originally organized by Jefferson to oppose these evils. It ruled the eomntry for fifty of the seventy years of the present century, and protected us from dismion on the one hand and from centralism on the other, and from corruption. Under twelve years of rule of the Republican party, the Federal government is rapidly usurping power from the loealities and from individuals, and has hecome more corrupt than was ever imagined possible. The masses of the Republieans, like the masses of all parties, are honest. No donbt some allowance ought to be male for the effect of a wreat war. But the system of false finance which has corrupted us into a nation of ganblers was as mnecessary as corrupting. And the principle and measures of the Repullican party, their centralism, 


\section{LETTERS AND MEMORIALS OF SAMLEL J. TILDEN}

tariffs not for revenue but to control the labor and capital of the people, legislative grants and jobs of all kinds tend to corruption. And the ideal standard of their statesmen is lower than any ever held by the followers of Jefferson and Jackson.

\section{"State Government.}

"In 1846, twenty-five years ago, I went to the Assembly to sustain the administration of Silas Wright. Not a man in either House was even suspected of corruption. The Democracy under Martin Van Buren, Silas Wright, William L. Marey, and Azariah C. Flagg had ruled the State during the life of the old Constitution from 1821 to 1846 . They were all men not only of transcendent ability, but of personal purity. They gathered around them men of like character in all the counties. They. wielded party power not only in favor of good measures, but in favor of good men. No corrupt Senator or Assemblyman could live in their atmosphere. The race ran out.

"From 1846 to 1870-23 years-the Democracy never had a majority in the Senate, and but twice a small majority in the Assembly. Those bodies became what the Republicans, and the party from which they sprang, have made them. When William H. Seward and Thurlow Weed came into power the character of the legislative bodies fell in an instant, and during all the 23 years of Republican ascendancy it continued to fall."

$$
1871-1872
$$

\section{TILDEN TO W. CASSIDY}

"Confidential.

“New Lebanon, Aug. $18 \% 1$.

"Mr dear CAssidr, - I think you had better note the tone of the 30 or 40 extracts which the Times daily publishes from journals of all parts of the United Statesnearly all administration, but a few Democratic. It indicates the mode of using the exposures of the Times which are employed thronghont the country.

"Two ideas are sufficiently apparent now:

"1. That the evils and abuses in the local government of 272 
the city of New York are general characteristics of the I) emocratic party, and would wecur in the Federal government if that party should come into power at Washington.

"This argument, fallacious though it be, is likely to satisfy the Republican mind and to animate it to effectiveness; and to confuse and embarrass the Democratic mind, and render it ineffective, if not irresolute. The immense preponderance of the Republicans in journalism, and the situation of this local cancer, directly under the focus of that joumalism, which makes it more conspicuous to the eye of the comntry than a hundred such would be if existing in remote or obscure parts-the peculiar and remarkable clearness and certainty of the proofs compared with the inferential and argumentative nature of the cvidenee in such cases usually, are cireumstances which go far to enable the Republicans to snceed in propagating this idea. We are out. Onr ease requires not merely firmness in holding our position by our veterans, but aftimative, aggressive action, resulting in accessions from the hostile or neutral, eaptures from the enemy. If the higher morale-the hetter weapons, the stronger ammunition-are not with us, but against us, low are we to be capable of the kind of warfare neeessary to the situation?

"2. The second idea is that the leading Democratic journals defend the wrongs alleged, thus impliedly adopting them or admitting a responsibility for them, which does not allow of disavowal and condemnation.

"A mode of discussion which countenanees such a construction is not only wrong but foolish, both in respect to the party and the jommal. All that can be conceded to the accused is the benefit of whatever doubts may exist as to their guilt. It will not do to set off similar wrongs alleged against the other party, for that, if frequently repeated, will gradually foster in the public mind the enclusion that we admit these wrongs to be properly carried to our side of the account. The idea slould be kept all the while before the public mind that the Democratic party is not responsible for these wrongs; that it will be foremost in punishing the authors and foremost in adopting all moasures necessary to prevent their recurrence. The first impression is important, and persistent repetitions of that impression are necessary to affect the public mind. The point of the article which was commended by Mr. Kernan, Gov. Beach, and 


\section{LETTERS AND MEMORIALS OF SAMUEL J. TILDEN}

myself needs to be presented again and again - perhaps with even more distinctness-until it attracts more public attention than it seems to have done. This is especially necessary in view of the articles in the World."

\section{S. E. CHURCII TO TILDEN}

"Albion, Aug. 1, $18 \% 1$.

"Hon. Saml. J. Tildden.

"MY DEAR Sir,-The ticket this fall must be made up of sound men who will inspire confidence, or we shall be beaten. I think the party in the interior are all right if properly attended to. The awful 'botch' made in suppressing the riot, and the ventilation of financial matters in N. Y., are calculated to weaken our strength in the country, and something must be done to counteract their influence. Is it not a good time to dismember the New York ring? How does Hall relish the position in which he has been forced? It is so long since I have heard from you that I almost think you have forgotten me. Are you not coming West before the State convention? I have got to living now, and shall be glad to see you. At any rate, write me.

"Confidential. "Truly yours,

S. E. Churcil."

\section{HORATIO SEYMOUR TO TILDEN}

"UTicA, Aug. 12, $18 \% 1$.

"MY DEAr Sir, - In the matter of the 'caucus,' do nothing until you are called in. In the mean time let the Rcpublican surgeons hack and cut away. There can be no better time. When the public mind is turned to the question of frauds, etc., etc., there will be a call for the books at Washington as well as in the city of New York. I think a spasm of virtue will run through the body politic. Business is dull. The farmers are getting poor, with no look ahead of better times. Immigration, railroads, and machinery are crowding the markets with provisions and breadstuffs. Taxes are now felt as they have not been since 1860. The corruption in our party is local. In the Republican party it is pervading. We can lose nothing by stirring up questions of frauds. I hope I shall meet you 
soon. In the mean time see more 'devil opements' and ean judge better of the conrse to be taken.

$$
\begin{aligned}
& \text { "Truly your's, } \\
& \text { "IIoratio Seymour." }
\end{aligned}
$$

TILDEN TO MR. PURCELT

"NEw York, August 12, $18 \% 1$.

" $\mathrm{MY}_{\mathrm{Y}}$ DEAR Sir,-Returning to the eity two days ago, I formd your note.

"The better way to see me would be to meet me at Saratogat. When can you be there? Communicate with me by telegraph, if necessary.

"I am not molservant of the situation. The question is what are our people morally able to do? Would you allow your opinion to be public, and attend at the place where a convention should be held? What would Jarvis Lord do? What Dellolf?

"Some of our people from the interior think the recent exposures will not hurt us much in the country distriets. That is not my opinion. I should be sorry to think the demoralization is so great that such things would not hurt us.

"We have to face the question, whether we will fall with the wrongdoers or whether we will separate from them and take our chances of possible defeat now, with resurrection liereafter; possible chances, I say, for if the party could act unitedly I do not despair that we conld save it now.

"I have not time to write now, but I hasten to acknowledge your note.

"The best immediate thing for you to do is to have the Union* begin at once prudently to disavow and denomince the wrongdoers, and educate our people.

$$
\begin{aligned}
& \text { "In laste, } \\
& \text { "Very truly Yours, "S. J. Tirden." }
\end{aligned}
$$

\section{JOIIN A. DIX TO TILDEN}

" 3 IVest 21st St., 2 Sept., 1871.

"Mr DEAR Sir,-T am just going to my country-place at Westhampton, Iong Island, and am sorry that I cannot have a few minutes with you to talk about eity affairs. It

* Rochester Union and Advertiser, of which Pureell was promoter. 
seems to me that every honest man must be sincerely desirous of a thorough investigation; for, independently of the wrong to the taxpayers, it must be evident that popular government cannot be maintained unless the authol's and sharers of the plunder, of which we have unquestionable evidence, can be discorered and disgraced. I earnestly hope that you, who stand before the community with as enviable a reputation for integrity as any man in it, and who can do so much to effect the object in view, will take an aetive part in the movement which is in progress.

"I wished to see you on another matter. I have looked for two years in vain for my war-horse. He has disappeared. I have, therefore, got another horse - not a warhorse, I hope. If you have not parted with my saddle and bridle, are you willing to let me have them? As my seat was molded to the saddle by six years of daily use, I should not probably find another so well fitted to it. If you will do so, and at the same time let me know their value, you will greatly oblige me.*

$$
\text { "Yours very truly, }
$$

\section{"Hon. Saml. J. Tilden.}

"My address is $3 \mathrm{~W}$. 21st St. My son forwards my letters when I am out of town."

\section{S. J. TILDEN (CIRCULAR LETTER AS CHAIRMAN OF THE DEMOCRATIC STATE COMMITTEE)}

\section{“NEw York, Sept. 11, $18 \% 1$.}

"Dear Sir,-The time between the meeting of the State convention and the election being a little shorter than usual, it has been deemed advisable to begin preparations for the canvass at once, so that even more than the ordinary period for organization will be afforded. The poll-book for your

* Mr. George W. Smith, my colleague as Executor of Mr. Tilden's Estate and at the date of the following letter his private Secretary, writes me:

"The horse General Dix refers to, and which he had in Virginia, was a gray horse, about sixteen hands high, and a remarkably easyriding horse. Mr. Tilden, I think, bought the outfit of him-horse, saddle, and bridle-just before General Dix went to Paris, and paid him $\$ 300$. Before the general's return from Paris, Mr. Tilden put the horse in in part payment of another horse. The general never recovered him." 
distriet has been already sent to the ehaimman of your comnty committee, and may be had on application to him.

"The Democracy have never been ealled on to act when wisdom and comage, and devotion to principle and to right were nore needed than at the State convention about to be held.

"I appeal to you, therefore, to attend the primary meeting which will choose delegates to your $\Lambda$ ssembly district or comb convention, and to send to that convention your most discreet and best eitizens, in order that they in turm may choose as delegates to the State convention men eminent for judgment, integrity, and honor, and who have, in the larest rlegree, the trust and confidence of their fellowcitizens.

"Centralism in government and corruption in administration are the twin evils of om times. They threaten with swift destruction not only civil liberty, but the whole fabrie of onr free institutions.

"The Democratic party was organized by Jefferson to oppose these identical evils. It conducted the national government for fifty of the seventy years of the present century, and gave the people safety, prosperity, and happiness.

"The present demoralization has happened muler the aseendeney of the Republiean party; and though the mass of them, like the mass of all parties, are honest in their intentions, and some allowance onght to be made for the demoralizing influence of a great civil war, more of these results are to be ascribed to the utterly false and corrupting system of finance umnecessarily adopted by these Republican administrations; and there is no dontht the tendency of the principles and measures of the Republican party is unfarorable to purity in government.

"In the State, the Democracy ruled for twenty-five years -from 1821 to 1846 -meler Van Buren, Wright, Marey, and Flagge; and corruption, always condemmed and pmished by them, was almost mknown.

"In the 24 vears from 1847 to 1870 the Demoeracy never had a majority in the Senate. Twice only did it have a slemder majority in the $\mathbf{A s s e m b l y}$.

"The Republicans had the legislative power of the State, and that is now the government both at Washington and at Albany.

"The Republicans made the morals of the legislative 
bodies what they have recently been. When Seward and Weed took the place of Wright, Narey, and Flagg, public and official morality fell in the twinkling of an ese.

"Even as to the eity government of New York, until 1870 , it was exactly what the Republican legislatures made it. The Republican party was born in 1855. In 1856 it swept the State by 80,000. In the Senate of 1857 the Democrats.had but 4 out of 32 members; in the Assembly, but 37 out of 128 .

"Then the Republicans made the eity eharter under which we have lived until 1870. At the same session the same hand which created the Republican party created also the supervisor's board, which has been the source of all the corruptions in our eity government.

"The league between corrupt Republicans and corrupt Demoerats which was formed during Republican ascendency was too strong for honest men in 1870 . The eharter of that year had the votes of nearly all the Republicans. I denounced it in a public speech.

"Wherever the gangrene of corruption has reached the Democratic party we must take a knife and eut it out by the roots.

$$
\text { "S. J. Tildene." }
$$

W. F. HAVEMETER TO R. B. CONNOLLY

"New York, September 16, $18 \% 1$.

"Richard B. Connolly, Esq.

"Sir, - I have considered the question which you have submitted to me; and, to prevent the possibility of misapprehension, reduee my advice to writing.

" 1 . On the assumption of your innoeence of the eharges made against you, I do not consider resignation of your office as your proper course. Your duty is to give every facility to the fullest investigation, and to abide the result.

"2. In your answer to the request of Mayor Hall for your resignation, you have stated that your official acts which have been impeached were 'supervised and approved by the superior vigilanee' of Mayor ITall; that equal responsibility for them attaches to him, and that, in his affidavits in the pending litigation, those acts were adopted and vindieated by him.

"Even if you are conscious of having done wrong in your 278 
trust, you owe it to the community not to commit another wroug, but to make every reparation within your power.

"T'o surrender your office into the hands of a confederate would be a fresh betrayal of your trust; and, while it might danage yourself, would fail of doing justice to the community. You practically make your own successor. As the law now stands, he can assume your office only by an arrangement to which you are a party to create a vacancy for him. The man you give place to onght not to be the tool of those implicated in the transactions which excite the public distrust and alarm. He slonld be the nominee of the citizens now secking to protect the people. In that way alone can he lave the confidence of the public, or sustain the credit of the city.

"No nan selected by Mayor IIall can, without some other" moral support from the community, have the public confidence. Te will be compromised by a previous understanding with the Rodin of the 'ring' or by the acceptance of the favor.

"Fortumately, the law affords a perfect solution of the case. By sec. 3, chap. 57t of the laws of 1571 , you are authorized to appoint a deputy comptroller who, in addition to his other powers, possesses every power and shall perform every duty belonging to the office of comptroller whencrer the said comptroller shall by due written authority, and during a period to be specified in such authority, 'designate and anthorize the said deputy comptroller to possess the power and perform the duty aforesaid.'

" $\mathrm{My}$ advice to you is to forthwith appoint Andrew $\mathrm{H}$. Green as such deputy conptroller; to leave him to exercise the full powers of your office without conditions and without interference; with complete custody of all books and papers bolonging to your office; with the appointment of all persons whom he may think necessary to protect the public property and interests, and to enable lim to carry out the most searching investigations, and to aid the committees appointed for that purpose.

"I have ralefully considered the selection I recommend. Mr. Green has knowledge and experience in the affairs of the eity; has the most reliable character for integrity; has no relations which conld mislead hinu by had influences, and is strong in the public confidence. If you adopt my advice 


\section{LETTLRS AND MEMORIALS OF SAMUEL J. TILDEN}

I shall insist on his aceepting the disagreeable duty for the sake of the public interest."

W. F. HAVEMEYER TO $\Lambda$. H. GREEN

"Sept. 16, $18 \% 1$.

"Mr dEAR Sir,-In advising the comptroller as to certain questions which he has submitted to me, I have deemed it best to adopt the shortest and most direct way to get at the condition of affairs in the eomptroller's office and of the city government, in order that the public may have the carliest information relating [thereto]. To this end, I have advised the comptroller to appoint you his deputy, and to commit to you all the powers of his office without conditions or restrictions. This he has consented to do, and I enclose his appointment without conditions. I have no doubt that this position in the present condition of affairs will be most distasteful to you, but I deem it your duty promptly to aceept its duties, and to do what you can to aid in restoring order and system in the financial affairs of the city. I have advised him not to resign, but as the best thing that can be done, under the circumstances, to appoint a deputy in whom the publie has confidenee. Of course you cannot accept the position with any restrictions as to the future or the past.

"Yours truly, "W. F. HAVEMEYer."

\section{R. B. CONNOLLY TO A. H. GREEN}

"Comptroller's Office of the City of New York, "Sept. 16, 1871.

"Mr. Andrew H. Green.

"My DEAr Sir,-The office of deputy comptroller of this eity having become vacant by the removal of Mr. Richard A. Storrs, I hereby designate and appoint you, Andrew H. Green, for that office, deputy comptroller of the eity of New York, and earnestly press upon you the aeceptance of this position. The critical juncture in the affairs of the eity and the condition of public sentiment seem to demand that the important transactions of my department should be conducted by one possessing the unlimited confidence of the public. In determining upon the action required by the present exigency, I have been guided by the advice of gentlemen whose respectability and prominence 
clevate them above all suspicion of unfair or interested motive. I an endearoring to ant with sincere regard to the pullic interest and to insure it against pussible sacrifice, and pursuing the authority and phrasedogy of the statute $T$ hereby designate and authorize you to possess the power and perform all and every dnty belonging to the office of comptroller of the city of New York from the time of this appointment to the first day of Jannary, 1872.

"Very Respectfully."

\section{CHARLES O'CONOR TO S. J. TILDEN}

“N. Y., Sept. 29, 1871 .

"Mr DEAR Sir,-T have given the hest attention in my power to the matters mentioned resterday.

"1. My mind is fully and conclusively made up as to the convention. I will not attend it for this single reason. The post of duty on these oecasions is that in which one can be most useful. In my opinion this little use of ny nativity is the proper renue for my action. Appoint me, if you like, give me a respectable alterinate, and I will write him a letter.

" 2 . I think it would be very inexpedient to take Mr. Green out of the eity for 24 hours. He ought not to go to Rochester.

"3. I have little knowledge of Comnolly, and no aceess to him, nor womld I be willing to have any. Consider:

"1. Nust rou not in resolutions, ete., body forth the detemination to compel robbers to lisgorge and even to inflict punishnent, cte.?

"2. Will 'Slippery Dick' stick to his integrity steadily for weeks, in the face of a lazard like this?

"Therefore,

"3. Is it not desirable to strike whilst the iron is lot. get a resignation and the appointment of 'Handy Andy' as I perecone the slow wits of the opposition begin to call him? It is not a bad name, and might do a man good who somght preferment, if he could get it to stick. IIandy Andy blumdered, to be sure, but lie was faithful and honest in the last degree, and his bumders were true Irish bulls; they excited merriment, thus roing good to the souls and bodies of the observers; a certain naïe wit hung around each erroneous eonception that evineed a good motive; besides, there was in each a singular approximation to cleverness and a 
kind Providence always effectively gainsaid any actual evil in the results.

"Mr. Tilden."

$$
\text { " Yrs. truly, }
$$

\section{S. J. TILDEN TO FRANCIS KERNAN (TELEGRAM)}

"To Hon. Francis Kernan, Utica:

$$
\text { "(Sept. 30, 1871.) }
$$

"Anti-Tammany organizations letter received. All have united on delegation headed by Charles O'Conor and Oswald Ottendorfer, and filled by our strongest representative citizens. Nearly all will personally attend. O'Conor gives his soul to the movement, and considers compromise as equivalent to ruin in State and nation. That is also my opinion. Action and not words can save us, but it must be complete and decisive action, and must fully satisfy the public opinion and the immense masses who now accept our lead and are strong enough to carry us through to success. We have no danger except in half-measured and half-hearted counsels."

\section{CH. O'CONOR TO TILDEN}

" Oct. 2, 1871.

"Dear Sir,-I have not time to call upon you this morming, although I wish to see you very much.

"If you should be in Wall St. early, perhaps you will step in.

"I wish to show yon my letter. It may not be altogether satisfactory to yon, and, if not, perhaps it should not be sent.

"I stated to you that I had some invincible scruples concerning the men, or rather the organizations who, acting as reformers, shonld be admitted as anti-ring representatives.

"Suddenly and without my consent my name appeared in the papers in a certain association not satisfactory. I have had great difficulty in reaching a satisfactory conclusion as to my course, increased by the circumstance that I have not had a single human being to consult with, and, in such things, one does not like to be alone. But my mind is now fully made up, and my action will be decisive, accordingly. I shall regret if in your eagerness to fix and annonnce my enlistment any laudable design on your part shall be in- 
juriously affected. But for such a result, if it ensues, I shall feel blameless.

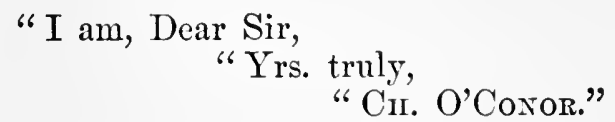

\section{HORATIO SEYMOUR TO TILDEN}

"Utica, October 8, $18 \% 1$.

"Mr DEAr Sir,-I have not been well since I got back from liochester, but I have turned over the state of things in my mind, and I now sit down to give you the ends I have reached. When I left home I thought our friends had made up their minds to take high ground. When I met Lord and other's at your room I saw at once 'the switch had been changed.' 'When Lord asked about the ticket I knew that a party had been made up to which you and Kernan and myself were not to be invited. Of that I am proud. All of the officeholders, the canal contractors, ete., are in it. Warren, DeWolf, and Cassidy lead the move. It is not in my heart to say an unkind word of Cassidy. In many ways he has had a hard time. His fine mind has been nsed by others while he was left poor. It was the strange policy of the Central Railroad men to give wealth to Weed and others, who fought them if they did not, while Cassidy was helped to live by loans and in other ways which kept him poor. When Tweed went to Albany he turned a stream of patronage into the Argus office which made it strong and rich. I think Cassidy means, in the main, to stand up for the right, but it is hard for him to strike men who have lifted him into wealth and when all about him shrink back. Now what are we to do? A new party is made up, and we are outside of it. For this I am glad. But this is not all. We may forgive others, but the men who have left us will not forgive us. The old ties are broken. They have yielded to temptation, and now they are like ehurch members who have fallen from grace; they not only hate to meet their minister, but they learn to hate him. This feeling eropped out at Rochester. They were glad to hit us, and the young men wonld have done more if the wiser ones had not held them back. Tou would have been put off the State committee and McQuade would have had the seat of Kernan if they had thought it wise. All things were made ready 
to do both of these acts. While Kernan was thrown off of his guard by Van Buren's assurances that his seat would not be contested, the conmittee on eredentials was made up; their names were known to MeQuade's friends, and an active canvass was made in his behalf. The plan was either to reject Kernan or to keep him out until the Tammany men were made sure that their seats would not be filled. I made up my mind to go home. I told Mr. Warren I would not act as president of the convention. In the evening I was very ill, and when the committee called upon me I said I was not well enough to go into convention. This was true, but I am sorry I put that reason out. I was in so much pain that I had not my wits about me. I should have said to them, as I did to Warren, simply that I would not preside.

"Now what are we to do? You know that I hold that all that a man does about politics after he is sixty years old is only meddling with other people's business. But duty may force us to act, and then how do we stand? The Democratic leaders and organization are dead against us. The members of the convention went home pleased with the diplomacy of their leaders, but with lower tone of morality than they had when they left home. The young men we looked to with hope in the future are debauched. They were willing to have Tammany coaxed out of the convention and then to slam the door in the face of the honest men who had unearthed crime in New York. When the leaders had done their work on Thursday noon the Tammany men stood in the light of having acted in a high-toned, generous way. The convention was grateful to them for allowing it to say stealing was wrong in a way that should hurt no one's feelings. The anti-Tammany men were in disgrace and disfavor. The majority of conrention wanted to leave matters in that shape, and they were angry when you and Kernan and West and others forced them to do a few decent acts. I think you saved the ticket by this. I know you saved your honor. You must now count upon the hostility of old supporters and of all State officials. You are in the way. If you mean to fight you can do so by means of the new parties in New York. Yon must hold them up to the highest tone and to untiring actirity. You must put yourself at the head of the reformers and use your list of correspondents for any papers you wish to send out to enlist the country against frauds. I have stated all the odds 


\section{LETTERS' AND MEMORIALS' OF' SAMUEL, J. 'THIDEN}

against you, but you can whip the party back to right grounds if you wish to do so. It is on the defensive now. "Truly yours, de., "Holitio Serarour."

WM. PURCELL TO TILDEN

“ Rochester, N. Y., Oct. 25, 1871.

"Private.

"Dene Sik,-No single incident of the war against the machine has given the people everywhere so much joy as the amnouncement yesterday by telegraph that Charles O'Conor harl been tendered an Assembly nomination and had not declined, but justified the hope of his acceptance. The acceptance and election to the Assembly of O'Conor' would, in my judgment, aside from what he might be able to aceomplish by official action, bo productive of a good moral effect that is incalculable. ITe occupies a position today prouder than that of any President or erowned head. Universally recognized as the foremost man of the bar, and unreservedly trusted as a guardian of the people's rights and interests in a time of great peril, all eyes are turned towards him as a sort of savior in this era of corruption in governmental administration. II is declination now, after giving ground for hope, would be disheartening. I earnestly trust that the pressure will be brought to hear upon him so strongly that he will not disappoint the people.

"You yourself ought by all means to go to the $\Lambda$ ssembly also. While your position differs in some respects from that of Mr. O'Conor, your presence at Albany this winter would be no less important. You have led, are the leaders of, the fight against the machine, and, of comrse, have ineurred the hostility and hatred of the machine men and their henehmen in different parts of the State. The fight will be eontinued in varions forms at Albany during the session of the Legislature, and you ought to be there to direct it, as well as to do service on the floor of the Assembly. Our Demoeratic press, that is heartily in the good work, must speak out fully and boldly of all proceedings this winter, and not leave iniquity to be cloaked and public sentiment to be formed ly subsidized newspapers and newspaper correspondents at Albany. I have never given Albany matters during the session much attention lieretofore, but next winter it will 
not be my fault if the public of western New York do not learn through the Union what is going on, and all that is going on.

"Everything here looks well. I think we will elect Lord Senator.

$$
\begin{aligned}
& \text { "Yours, \&e., } \\
& \text { "Wir. Purcell. }
\end{aligned}
$$

"P. S.-It would amuse you to see some of the written suggestions I have received since the fight was won at the State convention from those who condemned my article of the 3rd on the 'Paramount Duty', and who wanted to 'fix things up in some way with Tammany.' One of these, in particular, is cool-suggesting to me that 'the true policy now is to eut loose from Tammany Hall' !"'

\section{CIIARLES O'CONOR TO TILDEN}

"Oct. 28, $18 \% 1$.

"DEAr Sir,-I answered, declining, and they have determined to run Horatio Seymour without asking his consent.

"My letter, very full and condemnatory, is ready for the press. I don't much like to print it without consultation, especially as to one point. But later than Monday morning would be too late. What shall I do?

$$
\text { "Y'rs, \&c., }
$$

\section{CHARLES O'CONOR TO TILDEN}

“N. Y., Oct. 29, 1871.

"Denr Sir,-There are [no] Sundays in revolutionary times. So I am at work. The declinature is corrected and all ready. I am to have copies this afternoon for my intended constituents; it will be out in all the morning papers.

"But the greatest of the great productions of the day has just passed under my eager eves. The speech of Frederick A. Conkling, a conspicuous Republican, is the true touchstone. Surely every honest heart in the land will be thrilled with patriotic emotion by its stirring tones.

"What do you say to this?

"Beginning to-night, let us print at once in the large octave called royal, on good paper, in large type, easily read and every way in good typography, my poor effort in the decli- 
nature and this glorious Conkling speech. Thus the views of Democrat and Republican may go side by side. It should be added that a menber of the lexpislature need not reside in the district that elects him. Every one don't know this. By making it known we might yet lave, in the Legislature, not only yourself, but Seymom and Kernan and Minturn and other's that I camnot now think of. Conkling, too, of course.

"Kaman would be a grand candidate for the Senate against 'Tweed or' Norton.

$$
\text { "Yours truly, O'Conor." }
$$

"P. S.-Conkling's specel was in Herald of 27th. I send it to you. Don't lose it. Speed and vigor for God's sako and the Republic's.

$$
\text { "Yours, O'Conor." }
$$

ROYAL PIIELPS TO S. J. TILDEN

"Private.

“ 22 East 16ti St., Saturday Evening, Nov. 4, $18 \% 1$.

"Mr dear Mr. Tilden,-You must not be allowed to spend any money for your election. Your noble conduct has made all honest Democrats your debtors. I lave just sent my subseription to Mr. Cooper, but there must be many expenses which the committee cannot provide for, and on Monday I will send you a check for $\$ 250$ to aid in your personal expenses.

"It has only just occurred to me that we should all strengthen your hands, or I should have done this before.

"Very truly Your friend, \& prond of your political course, Rovil Phelps."

\section{IAMILTON FISH TO TILDEN (FNDORSING Ml. TILDEN's COURSE)}

"New York, Novr. 8, 1871.

"MY DEAR SIR, - An old personal friend, whose views on political questions lave generally differed from yours, thanks yon from the bottom of his heart for your noble work, your manly, homest exposure of wrongs.

"On your election I do not congratulate you, but the public.

"There is light ahead!

$$
\begin{gathered}
\text { "In haste, very truly y'r friend, } \\
287
\end{gathered}
$$




\section{IIENRY ADAMS TO TILDEN}

"Hanv. Coll., Cambridge, Mass., 9 November, $18 \% 1$.

"Dear Sir,-Now that the struggle in New York is over and the political labor, I presume, at an end, I venture to approach yon with a request to which I earnestly hope you will find yourself able to accede.

"Yon are probably aware that the North American Review has taken occasion, from time to time, to follow up the history of the great scandals which have made New York so unpleasantly famons, especially the Erie troubles. I am desirous of plaeing on record, by the side of the 'Chapter of Eric,' an account of the 'Tammany frauds and their history, given by a person whose anthority is decisive. In view of the further questions relating to New York government, likely to eome up before your legislature and in the press, it seems probable that a clear and a non-partisan (that is, not Republican) statement of the case may be of political value as well as of historical interest.

"An accomnt, therefore, of the Tammany frauds and their occasion, of the struggle of Tammany to maintain itself after the discovery, and of the means by which it was overthrown, and, finally, an expression of opinion as to the proper means of preventing such evils in the future, seems to me to be required.

"I know of no one except yourself who is capable of doing this properly. You alone know the private history of the affair, and have the means of estimating the actors at their proper value. I renture, therefore, to ask you to do it. If, as I believe, this story is to become historical, I am anxious that historians should be rightly informed as to the facts.

"In ease there is any chance of your undertaking the task, I shall hope to hear from you shortly.

$$
\begin{aligned}
& \text { "I am, y'r obt. Servt., } \\
& \text { "Henry Adams." }
\end{aligned}
$$

\section{FRANCIS LYNDE STETSON TO TILDEN}

“ 120 Broadway, N. Y., Nov. 22d, 1871.

"Mr Dear Sir,--Having attended at your office a number of times for the purpose of delivering the enclosed lists, and not being able to find the time when your many and 288 
diverse engagements permit you to be at your office, I lave concluded (as perhape would have been hest at first) to scind to you, instead of personally delivering, the lists which you requested.

"The manuscript roll, which I anclose herewith, presents, in elasses corresponding to the $A$ ssemlly districts from which they are drawn, the names of young men of Democratic principles and good character, who, so far as I can learn, are willing and prepared to participate in the duties of active political life. Nhmost all the names submitted are those of young lawyers, thomgh I have not hesitated to include the names of gentlemen pursuing other arocations when I have learned of their personal qualifications for the task contemplated.

"Almost, though not all, of the names are taken from the roll of the Young Men's Ienocratie Reform Club, of which I send you a printed copy.

"In the eollection and classifieation of these names I have taken from my professional duties more tine and attention than would seem to me justifiable, were it not that I have been acting at the request of one who has himself spared neither time nor attention in the pullic service, and the purity of whose motives I have from childhood been taught to respect.

"Trusting that my labors may not be entirely irresponsive to your request, I remain,

$$
\begin{aligned}
& \text { "Very truly yours, } \\
& \text { "Francis Linde Stetson." }
\end{aligned}
$$

WILLIAN CASSIDY TO TILDEN

"The Argus, Almavy, Nov. 2\%, $18 \% 1$.

"Deal Tildex,-I find the Washington St. suite of rooms most cheerful and aceessible. The bedroom and bathroom are separated hy the partor, which is an objection, and the noise of the street may be objectionable. The suite at the south end-the new building-is frece from these oljections, and will prove, on the whole, most satisfactory.

"But it appear's from the following that some one else is to be consulted. What profound dissimulation you have exhibited! If true, it is your greatest reform government. Give my love to Emily Josephine. My wife sends con289 
gratulations, and will give a bridal party when you both come up.

$$
\text { "Yours, }
$$

\section{"William Cassidy."}

This letter was accompanied by the following clipping from the Sunday Albany Press:

"A grand wedding will take place in Washington County on Wednesday next: Miss Emily Josephine Smith to the Hon. S. J. Tilden, of New York eity. Many Albanians are invited. Our friend, Hon. Chas. Hughes, formerly member of Congress, will be the principal groomsman. The wedding-cards are models of neatness."

\section{J. W. EDMONDS TO TILDEN}

"New York, Dec. 12, $18 \% 1$.

"Dear Tilden,-As my journey to Washington is postponed indefinitely, I shall be at home this evening, which has been set apart for an interview with the reporter of the Times on the subject of the charter. I shall want to use, on the occasion, the papers I let you have on Sunday. If you will send them to me by the bearer I will return them to you to-morrow.

"Subsequent reflection has rather convinced me that I ought not to have declined answering your question as to what I received for my work on the charter.

"I declined as I did simply because I do so in all my professional business. Such is my general practice, but there are exceptions, and I see no good reason why this should not be one of them.

"What I received was $\$ 10,000$.

$$
\begin{aligned}
& \text { "Yours, \&c., } \\
& \text { "J. W. Enmonds." }
\end{aligned}
$$

\section{T. F. BAYARD TO S. J. TILDEN}

"United States Sexate Cifamber, Wasmington, Dec. 21, $18 \% 1$.

"Mr dear Sir,-The Senate committee of investigation and retrenchment have resolved to meet in New York on Wednesday, January $3 \mathrm{rd}$, and take testimony in relation to the abuses alleged to exist in the Custom House in that city. 
"Mrr. Casserly and I are desirous the investigation shonld not be fruitless or superficial. To prevent its being either we must rely on the friends of honest govermment and reform in both political parties to place us on the track of these abuses that we may unkennel them.

"If the ntterances of the Tribune, the Evening Post, the Sun and other organs are meant in earnest, they must now prove it by admitting us to their sources of information. If they rely upon their party friends in the eommittee, then, I fear, our hopes in the question will be blighted.

"I write you, knowing the grand service you have done and are doing, and becanse I believe your position and relation to the honest Repmblican leaders in the desired reforms will give you influence with them.

"Very truly and respectfully yours,

$$
\text { "i. F. Bayard." }
$$

\section{TILDEN TO IION. IIAMILTON FISII}

"New York, Dec. 29, $18 \% 1$.

"Mr dear Sir,-The rush of events, in which I have been and am, has given me no opportunity earlier to acknowledge, as I intended to do, your note of eongratulation and sympathy in respect to the recent municipal controversies. I beg you to believe that, among the many which events have brought to me, none is more appreciated than yours, not only because of the many year's of personal friendship which have subsisted between us, but-and more - because I think it was prompted by your feelings as a citizen of this great metropolis, closely and long identified with its interests and its renown.

"Aceept my thanks for the books you were kind enough to send me, and believe me,

$$
\text { "Very truly yours, "S. J. Tilden." }
$$

\section{CimArLes O'CONOR TO TILDEN}

"Fort Wasimggton, Dec. 22, 1871.

"Dear Sir,-I can do nothing in Wall St. So I mean, if possible, to stay here until the 26 th inst. This will afford an opportunity to put some matters in shape for the operations required after Jany. 1. 
"There will be such a pressure of the outs to get $i n$, and of the jobbers to stick a project here and a plan there that no reform charter can possibly be framed and accepted on Gov. Chureh's instantaneous plan.

"A few very brief enactments can be framed which will meet every public necessity, and thro' a commission a really good charter may be framed. The lean corruptionists, who see a prospect of pasture, will, of course, try to control the appointment and the action of the commission, but the faces which have been set like flint against the fat sharpers must also present a stern front to the lean. If the Legislature is to fail in its duty, perhaps so much the better. What his lazy Majesty the Pcople has long needed was a sharp prick of the corruptionist's spear. It may be that he is not yet sufficiently aroused. Fainting in the legislature may be an absolute necessity.

The present pressing needs of legislation can easily be supplied. The muddle about the Aldermen is as easily disposed of as the Mayor, Tweed, and Fields. Lnckily, the law point is manifestly against the recently elected Republican Aldermen. We can show how to give them their seats.

$$
\text { "Y'rs, }{ }^{6 \mathrm{CH}} \text { O'Conor." }
$$

\section{H. F. TAINTOR* TO TILDEN}

$$
\text { "N. Y., 24th Feby., } 1872 .
$$

"Mr denr Sir,-Mr. Palmer, prest. Broadway Bank, gives me permission to attend at his bank only from 3 to 6 o'clock P.s. each day, except Wednesdays.

"With this gracious promise on his part I have twice to-day applied to Mr. Green for two or three men to assist me during these three hours, but can get nothing from him. When I asked him to allow me to employ ontsiders (after he had informed me that he had no men to furnish me) he refused, stating that if once men were on his hands he couldn't shake them off.

"For myself to go there alone each day to examine these old books and papers will be merely child's play, and I am much disappointed at Mr. Green's action. Palmer's conces-

* An expert accountant employed by Mr. Tilden to report upon the bank aceounts of persons implicated in the frauds of what is known to history as the Tweed ring. 
sions amomit to but little, and I forr our chances of getting what we desire are but slint.

"Permit me respectfully to again call your attention to the necessity of some legislation touching upon this point, whereby some person or persons can have the anthority to not only call for the information necessary, but also to ineur the expense necessary to a full examination.

"As the matter now stands it amounts to nothing.

$$
\text { "Respectfully, \&e., "H. F. Tainton." }
$$

The following eircular from the Grand Jury room gives the names of the parties then under suspicion:

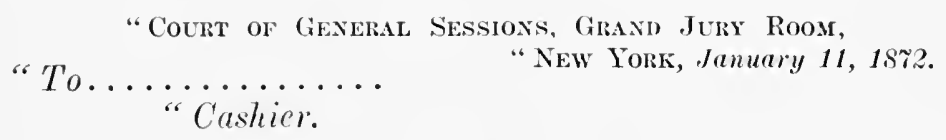

"Sir,-We regret to trouble you again, but from our present researehes we find it necessary to extend our inquiries to 1868 and 1869 ; and, in order to save the ineonvenience of calling you before the Grand Jury by a subperna for the purpose of answering the following interrogatories (in ease the Grand Jury should be willing to wave that right), I would thank you to state in a note to me whether an account was lept luring those two vears with your bank by either of the following persons, and if yes, by which of them, viz.:

"James M. Sweeny,

Peter B. Sweeny,

Ingh Sunith,

A. Oakey Hall,

J. H. Ingersoll,

N. Y. Printing Co.,

A. J. Snith,

Conrat Boller,

J. M[C]3. Darvilson,

J. IV. Snith,
Joel A. Fithian,

Wm. M. Tweed,

James Watson,

R. P. Commolly,

C. E. Wilbour,

Cornelins Corson,

A. D. Barber \& Co.,

J. A. Sunith,

Geo. S. Miller,

A. G. Miller,

Mrs. R. P. Comnolly.

"I will smbmit yomr answer, and take the further order of the Grand Inry.

$$
\text { "Yours, "fre., }
$$

"Foreman Grand Jury, Court of General Sessions." 


\section{CHARLES O'CONOR TO TILDEN}

"Feb. 3, 1872.

"MTr DEAR Sir,-G. wrote me a note last night, stating that from haste, etc., he omitted many things, especially facts relative to the transaction of 1869 .

"He is doubtless growing fidgetty and impatient in consequence of his privacy and solitude and the delay.

"I wrote him a reassuring letter, and suggested quiet on his part until the close of the Jumel trial. I promised then to take up the business and put things on a definite footing.

"Once that trial is over I shall be free; and if great and controlling reasons do not oppose, I will proceed at once to deal with the questions and the persons of the hour as public necessity shall, in my judgment, seem to demand.

"Ficlelity to a cause once espoused is the first law of my nature. This alone has tied me to these troublesome and engrossing Jumel law suits. They will be over when the corrupt gang of villains engaged in the present enterprise shall have got their quietus. This can hardly fail to happen within a fortuight; and thenceforth no private person's affairs shall prevent the entire devotion of all my time and power to the good cause in which you have so faithfully toiled and of which you have been the most efficient as well as the foremost champion.

$$
\begin{aligned}
& \text { "I am, Dear Sir, } \\
& \text { "Yours truly, } \\
& \text { "CH. O'Conor." }
\end{aligned}
$$

\section{TILDEN TO CIIARLES O'CONOR}

\section{“Jan. 28, 1872.}

" MY DEAR SIR,-The friend and the counsel of the gentleman we talked of came to see me last evening in response to a telegram from me. The former says and the latter assents that no change on their part has happened. It is obvious that the prejudice against venturing into this city is invincible; and they thought from the last interview that you did not feel interest enough in the matter to pursue it further.

"Their present plan is to have instructions issued which shall protect their man from arrest if he comes personally to his home, and then to have him come there and to have me or some other of us meet him at the house of his friend. 
"That, they say, they are willing still to carry out.

"The friend will be in town to-morrow.

"Now, what say you abont this?

"I might perhaps go to the town where he lives next Saturday.

"They' would want to be sure that he would not be molested, and perhaps would want to see the evidence.

"Y'rs,

"Charles O'Conor, Esq."

"S. J. Tilden.

"Jan. 2S, $15 \% ?$.

"De.sr Sir,-If you think fit to sce him you can give him promise of safe-conduct to and fro. But prompt action should be insisted on and a full diselosure.

"Yours truly,

"Mr. Tilden."

"Cir. O'Conor.

\section{A. OAKEY HALT TO TILDEN}

“ 13 West 42d St., Sunday, a.M. (1S\%2).

" $\mathrm{Mr}$ DeAr Str,-It was remarked in my hearing last evening, after you had so gratified the chn and its guests, 'Mr. Tilden looks as if he not only had a great head, but also a large heart.' I propose to address the latter, if you will graciously pardon the intrusion.

"I learn that Mr. Peckham intends procuring from the Oyer and Terminer G. J. a duplicate charge agst. ne for official neglect. It is in your power to arlvise against and prevent this. I think, sir, I can satisfy rou that such advice will be in harmony with that mflinching standard of justice by which you measure all men and all things.

"I have filed an unqualified stipulation that pending charges be removed to the $\mathrm{O}$. and ' $\mathrm{T}$ '. The removil order. has been entered. This would have been done before except that Mr. Vanderpool expected Judge Bedford to sit and make it pro forma. 'There is, therefore, no legal necessity for a duplicate. To press one now is only to wound the feelings of my very interesting fanily by arousing fresh (and doubtless, at this partisan pitch, cruel) newspaper criticism, and withont accomplishing any better oblation to justice (cither to me or the people, as the ease may prove) than could be attained with existing pleading. And espe- 
cially when some weeks ago I wrote Atty.-Genl. Barlow I should always be ready for his eonvenience.

"I think, sir, that ever since, in Sept., 1S71, I became convinced of the monstrous frauds (committed by men whose offences are condoned, or whose battles are carried on over my shoulders, because I neither skulk nor avoid fight) I have done much to atone for any imputed neglect in my acts as an auditor during the month of terrible mental trial to me which followed the inanguration of the new charter (May to June, 1S70), as well as to entitle me to consideration upon a mere question of discretion like this I now ask you to prefer to Mr. Peckham. I say discretion, because, were it a question in his mind of imperative right towards his affirmative action, I could not insult you, nor him, nor myself by the request to forego it. I shall always be willing to meet the necessary exactions of the law without asking favor. It is only against unnecessary applications I respectfully protest. Surely my unassailed administration as Dist. Atty. during 12 years; my bearing and course as Mayor in all save these unfortunate andits or non-audits (as you please to phrase it); the character of my appointments since Nov., 1871; my uniform support of Mr. Green in his trying position; and my surrender of much personal pride to aid even personal enemies in aceomplishing public good, ought to entitle me to ask from Mr. Peckham to be spared all unnecessary stigmas.

"Pray pardon me for thus amnoying you who, at this crisis, must be almost overwhelmed with duties. But when I heard the remark with which I began this note, the suggestion came to me with almost the intuition of a woman, and as if the whisper of a daughter-' appeal to his heart.'

"This does not require reply, nor is one expected.

"With great respect and regard,

"Your obt. sert., "A. OAKey HaLl.*

\section{"Hon. S. J. Tilden."}

TIL.DEN TO GEO. W. CASS

"Mr dear Sir,-I was compelled by what seemed for the time to be the most urgent of my many duties, to re-

* A lawyer who had been a member of the law firm of Brown, Hall \& Vanderpool, and at the time of writing this letter was Mayor, and inculpated with Tweed and others in municipal frauds. 
main in Albany a little after the diligent chairman of the judiciary conmitte had resumed the investigations held in this eity. In that interval, Mr. George Ticknor Curtis thought it pertinent to the defence of Judge Barnard to introduce certain statements concerning ne from Mr. Jay Gould. It happened, also, that the examination on this topic was conducted with so liftle art-or with so much art-that it totally failed to elicit the complete or substantial truth, and did produce, in practical effect, a mere falsehood. It happened further that, although the investigation is not public, the testimony on this point appears in this morning's journals, with an exceptional fulness.

"If I had heen present, I presume Mr. Gould's testimony eould have been developed so as to render any further statement to establish the exact truth mmecessary. But as it was not, the series of accidents-such I will assume them to be-that lave falsified the transaction, will excuse me in asking you to state the truth which is peculiarly within your personal knowledge.

"The IIerald report is as follows:

" $Q$. Did you employ any other counsel beside Messrs. Ficld and Shearman, in behalf of the Erie Railroad?'

" 'A. I employed several others.'

"Q. Who were they?"

"A. I had Jolm Ganson, of Buffalo; Judge Diven, of Elmira; and Samuel J. Tilden, of New York.'

" Q $Q$. When did you retain Samuel J. Tilden?"

" " A. In the year 1869.'

" $Q$. Did you retain him before this order was granted?'

" "A. Yes, sir.'

"Q. How much did rou pay Mr. Tilden?'

"A. 'T'en thousand dollan's.'

"Q. Wid Mr. Tilden ever, do anything for that ten thousand dollars?'

" "A. No, sir; on the contrary, I heard nothing about" Mr. Tilden until he turned up as counsel against the Erie Railroad in a case with the Atlantic and Great Western Railroad.'

"The Times report varies a little:

"Q. Dirl he ever" act als your comnsel?"

" A. Never to my knowledge, nor did he ever return the retaining fee.'

"Now, it is within your personal knowledge that the fee 297 
paid me was for a sear's service as counsel and arbiter in the executive committee of the Cleveland and Pittsburg Railroad Company. The arrangement was formed by you without my presence or knowledge; and the only communieation of the terms of it ever made to me was by you.

"In Jannary, 1869, the Cleveland and Pittsburg Railroad was placed in the possession of a receirer by an Ohio court, on the ground of fraud and breach of trust, committed or intended, by the then board of directors. Mr. Gould disavowed the acts complained of, and desired to have the road restored to the management of a board of directors to be newly constituted. You stated to me that the only feasible arrangement for a compromise between the parties was this: The executive committee was to be composed of myself, Mr. J. N. McCullough, the president, and Mr. Gould, who represented a majority of the stock then alleged to be held by the Erie Railway Company. I, who had no interest with either party, and was indifferent between them, was to hold the balance of power between the two other members, and be able to decide every question of law and every question of administration in respect to which they should differ. When the arrangement was submitted to me I declined the part allotted to me. I said I had no interest in the company, and never had any relation to it which imposed a duty in respect to it upon me. I declined more than once to you and Mr. MeCullough, notwithstanding the arrangement had been made by which the Erie was to contribute $\$ 10,000$ and the C. and P. $\$ 5000$ as compensation. I thought the trust might be troublesome and vexatious; and, at any rate, did not want the business. You, nevertheless, appointed me; and I afterwards acquiesced. I at no time made any conditions about compensation. I never rendered a bill. The payments, when they were made, were purely voluntary. I presume you do not doubt that nothing but your personal persuasions and those of Mr. McCullough induced me finally to acquiesce.

"You never" communicated to me that there was any idea on anybody's part that I should owe any duty to the Erie Railway Company except to perform my duties as counsel, director, and arbiter in the executive committee of the Cleveland and Pittsburg Railroad Company. I never assumed any other obligation.

"That duty I performed during the whole year. Upon. 298 
every question of law, of administration, of policy, I acted; and, as far as I know, with satisfaction to everybody. I had no difficulty with Mrr. Gould, who always behaved with consideration and deferenee. He got the company ont of its tronbles, and largely enhanced the market value of the stock by the arrangement, and appeared to be satisfied.

"Mr. Gould may well say that (exeept so far as acting in the Cleveland and Pittsburg was acting for the Erie) I never did act for the Erie in anything, so far as he knew. I never undertook to do so. 'There never was any gromnd to pretend that in any of the litigations of that conpany it had any claim to aid, or shelter, or comntenance from me.

"As to the Atlantic and Great Western, I never acted for the company. Prior to this time I had acted for MTr. A. C. Flagg and others, trustees under several of the mortgages, and for ecrtain bondholders; and Mrr. Gould knew it. Certainly, nothing in this engagement in the Cleveland and Pittsburg interfered with my right to continne to act for those trustees and creditors, or to act anew for them. In January and February, 1870, I argued before the Supreme Court of Pennsylvania and in the Ohio court, for the trustees and first mortgage bondholders, various questions as to the proposed lease. Mr. Gould faintly set up a claim that he was entitled to notice from me; and I at once reminded him that he knew all the time what my relations to the trustees and bondholders were, and had been for years, and that I had frequently, as their representative, had conferences with the commsel of the Erie. The nuion of the Atlantic and Great Western Company and the creditors inferior to the first mortgage with the Erie, prevailed; and a lease - which I believe all now agree was improvident and unwise-was made.

"I do not mean to say that it might not happen that a retainer is sometimes received and yet no further services rendered in the case. I presmue that this often happens withont impropriety. I have only to say that, so far as I recollect, it never has happened to me in any single instance of my professional life. I lave been content to receive compensation fixed by agreement with my clients after the services were rendered. I have, in no instance, had any controversy or difference of opinion with any client as to the amount of compensation. I have never heard of any 
discontent after the settlement, unless this may be such a case.

"Since there is an elaborate attempt to misrepresent an act of my professional life, I have a right to say thiswithout the imputation of egotism; and I have a right to add that, for the last sixtcen years, at least, my only trouble has been not to accept more business than I could perform according to $\mathrm{my}$ standard of duty and justice to those who entrust their affairs to my management; that I have not accepted half which has been offered of cases in which the clients were willing themsclves to fix my compensation to my full satisfaction out of what they would recognize as acknowledged benefits.

"And I have never hesitated to choose what business I would decline. At the outset of the famous litigation of the Erie, under the presidency of $\mathrm{Mr}$. Eldridge, it was communicated to me that the Erie desired to retain me; and afterwards Mr. J. C. Bancroft Davis, in its behalf, twice came to my office to offer me retainers. I declined. In 1869, Mr. James McHenry, when acting in apparent unison with the Erie, several times pressed upon me retainers in behalf of his scheme of reorganization of the A. \& G. W.; but, after considering his scheme, I declined. In the same year Mr. James Fisk, Jr., called upon me with Mr. Jay Gould. Mr. Fisk said, with many flattering suggestions, that they desired to retain me in reference to a matter then pending, and in the course of the interview he stated that they had paid within a year $\$ 125,000$ to a member of the bar, whose name he mentioned. I declined.

"I do not mean to imply that there would have been anything wrong in acting as counsel for the Erie in a proper case; but simply, when an act of mine is challenged, to state facts which are pertinent to my vindication. I have ever stood, not only in my personal conduct, but in my public influence, for the dignity and honor of the bar and the purity of the bench, and against whatever should tend to weaken or degrade the administration of justice. I did so, in 1869, when the evils of corrupt times were growing and powerful. I accepted issue in the Democratic State convention of that year. On the 1st of February, 1870, at the meeting which resulted in the formation of the Bar Association, T uttered these unpremeditated thoughts:

" "If the bar is to become merely a method of making 300 
money, making it in the most convenient way possible, but making it AT AL manns, then the bill is degraded. If the bar is to be merely an institution that secks to win eauses, and to win them by becki-door acess to the judiciary, then it is not only degraded, but it is corrupt.

"Sir, I believe that this comntry is to-night at abont the lowest point in the great eyele which we have oecasionally to traverse. I believe that there will come a someler and a better public sentinent, in which speculation and gambling and jobbing and corruption will lose their power, and in which free govermment will vindicate its rights to the confidenee of mankind. If I did not believe this, I should think that a very great part of my own life was lost, and all the traditions I have derived from my ancestors.

"The better day, to which-in that dark hour-I looked with hope and faith, is now dawning upon our eity, State, and country.

"New York, March 16lh, 1872."

$$
\text { "Very truly, yours, \&e., "S. J. Tiluden. }
$$

G. W. CASS TO S. J. TILDEN

"NEw York, Iarch 18, $18 \%$.

"MY DEar Sir,-I have this morning received your" letter of Saturday, and hasten to answer it, as I an to leave this city for Pittsburg this afternoon.

"Your statement of the facts comnected with the arrangement to pay you a comsel fee of $\$ 10,000$ by the Erie Railroad Company, for serviees in the Cleveland and Pittsburg Railroad, is strictly correct, all of which came within my personal knowledge.

"At the time, sinee, and now, I held and hold the position of president of the Pittshror Fort Wayne and Chicago Railway Company, which company then held, and still holds, a very important contract relation with the Cleveland and Pittsburg Railroarl Company. It was this fact that caused me to take an interest in the complieation in which the Cleveland and Pitt-bure Company was involved in 1869,

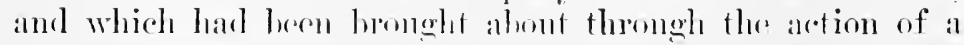
director of the Erie Comprany, that eompany at the time 
(as was believer) holding a majority of the stock of the Cleveland and Pittsburg Railroad Company.

"To free the latter company from the litigation in which it was involved, I came to this city and had an interview with the then president of the Erie Railway Company, who condemned the whole proceedings of what was called the 'Erie board' at Clereland. He agreed that a portion of the members should resign, and that yon and myself should come into the direction and the executive committee. I returned home, and, after a conference with J. N. MeCullongh, Esq., then and now president of the C. \& P. R. Co., a plan of reorganization was agreed upon, as set forth in your letter. To this date nothing had been said to you on the subject. On coming to this city, and developing the plan to you, you declined to go into the board or have anything to do with the business, for the reasons stated in your letter. I said to Mr. Gould and Mr. MeCullough-the latter more than once-not to urge the question on you any further, as you might take such a decided stand that we would not be able to overcome your objections, but that the plan should be proceeded with, and we should elect you into the board and take the chances of getting you to serve. This was done, and you were elected without consulting you farther or obtaining your consent. After the reorganization of the board the arrangement that you should be the umpire in the execntive committee, and have charge of all legal proceedings and be general commsel to the committee and board was arranged as you state, and without first consulting your. I took it upon myself to make such arrangements as would bring harmony into the board, believing you would acquiesce in such arrangement as I might make. Before you came into the Cleveland and Pittsburg board a resolution was placed on the minutes electing you the general comsel, and fixing the compensation. It was also proposed that owing to the interest which the Erie Railway Company had (controlling a majority of the stock), and the interest which the Pittsburg, Fort Wayne and Chicago Railway Company had by its contract with the Cleveland and Pittsburg Railroad Company, that each of those companies should retain you in their respective behalfs touching those interests. All this was done withont any indication from you as to what you would do.

"I afterwards learned from you that the Erie Railway" 
Company had paid you the ten thousand dollars, as agreed, without waiting for you to render a hill. 'The five thousand dollars agreed to be paid by the Pittsburg, Fort Wayne and Chicago Railway Company has nerer been paid or even spoken of since.

"The compensation above referred to was for those specific services and for no other, so far as I ever heard or believe. Those services eontinned to the close of the year, when you retired from the board. I remained in the board during that year and ever since.

"I will add that the arrangement made in 1869 was of large pecuniary benefit to the stockholders, and gave to the affairs, as well as the stock of the company, a stability they had never before had.

"I believe what I have written covers the whole caseat least I have so intended - and if, after I return from Pittsburg, it shall be found that any facts have been omitted, I shall be glad to supply the deficiency. "Truly yours,

"G. W. Cass."

\section{TILDEN TO LOGAN RAILEY*}

"NEW YoRK, March 28th, 18r2.

"Mr dear Sir,-I rec'd your letter, but find it difficult to get a moment in which to answer it.

"I camnot at present leave my duties to go to Kentucky.

"If I have a team, I want: 1. That each horse shonld be healthy (of sound constitution), a good feeder, and tough. I have had enough of horses which lose in whole or in part their feed after being driven, or which have to or a medicine. I do not want a horse that needs eare all the while to keep him well.

" 2. I want each horse to be of natural good temper and disposition.

"3. I want each to be free from all tricks, and perfectly sound.

"4. I want the two hor'ses to be well matehed in size, appearance, temper, and action. The color is of less inportance.

"5. I want them to move and act together as one horse.

* A famous dealer in horses in the New York market from Kentueky, and who supplied Mr. Tilden with his best riding and coach horses. 
"And if the horses you offer" are such, and if you choose to bring on the horse 'Morris Miller' at my expense and risk, and the other horse at your own expense and risk, I will take 'Morris Miller' at $\$ 5000$; and if the other horse shall prove satisfactory to Mingo and me on an opportunity of trial for a week or two, to be determined with reference to the weather and my being in town, I will give $\$ 5000$ more and the pony for the other horse.

"Of course, I do not want to try one horse alone, and in doing so rely upon your representation that the other horse will suit, and that the two will work together as you say.

"I enclose check for $\$ 5000$, which you can take if you approve these terms, but are to return withont using it if you do not affirm these terms.

Yours,

"S. J. Tilden."

\section{TILDEN TO MAIILON SANDS}

"New York, May 29, $18 \% 2$.

"Mr dear Sir, - I have this moment received your card stating that you "will take the liberty of using my name as one of the vice-presidents of the meeting to be held at Steinway Hall to-morrow evening, unless I inform you that I desire you not to do so.'

" My infor'mation as to the precise object of your meeting is very limited-if it can be said to exist at all.

"As I infer that the drift of the meeting is to touch the Presidential question, it is proper to say, that in a contest practically between Gen. Grant and Mr. Greeley, I think that a more liberal policy-as well in respect to the systems of revenue as in respect to the pacification of the South, the restoration of local self-government in those States, and the repression of the immense corruptions and wrongs which exist there-can be better worked out through the election of the latter than by that of the former.

"I therefore decline the proposed use of my name.

$$
\text { "Very truly Yours, "S. J. Timden." }
$$

\section{CHARLES O'CONOR TO TILDEN}

" Fort Wasinngton, June 1, $18 \% 2$.

"Dear Sir,-I am sorry you did not extend your ride as far as this. 
"I have been thinking somewhat intensely on a particular subject since I saw you.

"I mean in reference to a question of our personal action in a matter which, I suppose, is to conse off on Monday.

"I have made up my mind definitively that whatever you or others may think fit to do, $I$ will not, under any cireumstances figme in that affair.

"There can be no mistake about its being unfit.* I shall be sorry to stand alone, but I am not afraid to do so.

$$
\text { "Yours, "Cir. O'Conor." }
$$

RICHALD B. CONNOLLT TO TILDEN

“ Hox. S. T. Tilden.

June 1st, $18 \% 2$.

"Mr desR Friend, - Tt has been intimated to me by a mutual friend that I have expressed myself as to your acts towards me, previous to the actions of the courts and jury in reference to my case, that you had acted unkindly and in a manner that would not appear at all friendly. I assure you I have not done so, but, on the contrary, have always expressed myself to others that I was fully satisfied that the adrice I received from you and Mr. Havemeyer was for my benefit, and that both were governed by pure and patriotic motives. I did confess that in my actions I was influeneed by your advice, as being best for the public interest and for my advantage. Be assured, my dear sir, that while I live I shall remember with gratitude your very kind treatment to me during that eventful period in my life, and I know by my future acts I shall prove worthy of your friendship and esteem.

$$
\begin{aligned}
& \text { "As ever, } \\
& \text { "Yrs. faithfully, } \\
&
\end{aligned}
$$

CARL SCIIUl\%, JACOI; 1). COX, WIIIIAM CULLEN BRYANT,

D. A. WELLs, OSWALD OTTleNDORFER, JACOB BRIXKELILAF" (COMMTTTEL) TO TILDEN

"Confidential.

New Yопк, June 6th, 1872.

"The undersigned desire to have a conference of gentlemen who are opposed to the present administration and its

* This no doubt refers to the nomination of Greeley for President. 
such a ticket with great pleasure. I care nothing for the issues which are past, but $\mathrm{Mr}$. Greeley is directly against us upon the great living issues, those issues which began with our gort. and must last as long as it lasts. He has not, besides, the qualities which fit for the Presideney, but others which would make him the prey of the designing and corrupt.

"Must such a man be the Democratic candidate for the Presideney?

"I am unwilling to trespass on your valuable time, but should be very glad of a line from yon on this subject.

$$
\text { "Very truly, de., "Jonx J. TAYlon." }
$$

TILDEN'S ADDRESS TO TIIE BAR ASSOCIATION

"(Circa 18r2.)

"Gextlenes, - I congratulate you on the substantial progress which las been made in purifying the judiciary. Everything which at the beginning of the late legislative session you set before yourselves as practicable, everything which you were afterwards enconraged to undertake, has been accomplished. Yon asked for an inquiry into abuses in the administration of justice. You have had an investigation-patient and thorough-during seven weeks, in session continued from ten in the morning until late at nightcarried on in the presence of the accused and their counsel. It is true the inquiry could only touch a small part of the evil-the specific cases presented by you. But every judge against whom you made cliarges has been put on his trial, except one, who fled from the ordeal. I repeat to you tonight what I said at the meeting at which this association was organized. It was on Feb. 1, 1879-when the shameful perversion of judicial process and judicial power that characterized 1569 were fresh in the public mind, and the corrupt oligarchy, whose tools these julges were, seemed to sit enthroned over the prostrate people of our metropolis.

"If it will do its duty to itself, the bar can do everything else. It can lave reformed constitutions, it can have a reformed judiciary. It can have the administration of justice made pure and honorable. One word as to the pending impeachment of Judge Barnard. I do not share the fears which lave been expressed in the public journals as to the 307 
results. First, I know that in the investigation, which extended to all the witnesses the acensed desired to produce, and with full cross-examinations, there was developed more impeachable matter-ten times over-than can be found in the eight principal cases of judicial impeachment, four resulting in convictions which have occurred in this country. Secondly, I believe that the leading members of the committee of managers will faithfully prosecute the trial. Thirdly, I have the most absolute confidence in the abilities, professional skill, and earnest patriotism of the counsel who will represent the people, and on whom the real burden of the trial will fall. I respect the sentiments of my brethren of the bar which demanded that I should continue still farther my commection with the movement to purify the judiciary. I mean, of course, as one of the managers of the impeachment, for you all know that I would not have acted as counsel. While I did not feel at liberty by my own act to withhold any service which you thought I conld render to the great reform, my opinion differs somewhat from the public impression. The great work of investigation, of collecting eridence, and of securing sufficient concurrence and co-operation to put the accused on trial-which has been an immense and difficult labor-is done. The gentlemen whom I met in conference, after everything had been completed except to decide on the form of procedure - when I consented to impeachment instead of removal by concurrent resolution-and I see several of those gentlemen present, will remember that I then stated my difficulty in engaging in a prolonged trial during the summer. When the choice of the managers came to be made I did not feel called on to enter into a canvass or to form combinations. In everything else I had felt it my duty to exercise all foresight and every carc, and to exert every power I possess to organize such elements as could be found for good ends. In this I felt entitled to leave every human being to his spontaneous action. If $\mathrm{I}$ should receive an honorable discharge I had a right to accept it. I cannot be accused of selfishness if I did so with delight. One care only remained for me. That was to look after the choice of commsel. I communicated what seemed to be, in the actual circumstances, the best suggestions to Mr. Alvord, and met his prompt and cordial concurrence. Of Mr. Tan Cott-the senior member of the committee which represented you in the investi308 
gation-I need not speak. The eminent jurist with whom he will be alssociated-Iulge Constork-will bring to his duty great abilities, anple stores of learning, and an honorable pride in restoring the renowir of the bench and the har of this State. I remember with what solemn earnestness he said to me several years ago that we could never reform the julliciary of this district mntil we had first crushed the corrupt power which stood behind it. I do not see that justiee will be more likely to fail that the trial is to be conducted in the light of open day, with the eager scrutiny of the har of the State and comtry, and under the eyes of a watehful, apprehensive, and somewhat distrusting people. While what has been done towards purifying the judiciary is just cause of congratulation, you will appreciate the difficulties throngh which it has been obtained if rou reflect that everything else in the way of reform has failed. It is known to you that when I consented to go to the Assembly it was with a view to the judicial reform and to certain other measures more particularly interesting to the people of this eity, and that in that work I expected the eo-operation in the Legislature of $\mathrm{Mr}$. O'Conor and Mr. Evarts. This arrangenent was defeated by subsequent events. I thought that it was necessary to concentrate myself upon a very few measures in order to accomplish anything. The general demoralization growing ont of the Civil War and paper money had produced widespread effeets. The corrupt power whieh had just been overthrown in this eity had its origin in a partuership of plunder between nen nominally of different polities, but, in fact, of no polities at all, and had established extensive aftiliations throughout the State in loth parties and in both branches of the ilominant party which now possessed threequarters of the Legislature. It had been necessary to the system that the capitol should be surrounded by an atmosphere of corruption. The anbition of some had been tenpted; the interests of more had been addressed by making legislative business profitable, and the golden showers had sprinkled benefits in every direction. Some, even, who would not take an actual part in the saturnalia were content to be silent spectators or consenting witnesses. I never for a moment supposed that the knife and the cautery would be agrecable remedies, or that the silent partners of prosperous criminals would fill in love with those whose duty it 
is to detect and punish. I knew, therefore, that obstructions, under every pretext, were to be met at every step and to be overeome. Let us thankfully accept what has been accomplished; and let us here to-night renew our faith that if the bar of this eity and State will be united and persistent, every judicial reform in respect to men and in respect to systems will be at last successfully achieved."

\section{TIIDEN TO EUGENE CASSERLY}

"New Yonk, July 3rd, 1872.

"Mr DEAR Sir,-I did intend sooner to acknowledge your letter and make answer generally to it, tho I have foreseen that it is a case in which, as Gov. Seymour says, 'letters answer themselves,' and I should only pay my respects to you.

"The Cineinnati movement has been so early and long encouraged by you and by me and by many who thought with us, that it grew to have an impetus and volume which were important and not easily turned aside from the channel it made for itself. Our people, in being edneated to favor it, had become aceustomed to count on it, and at last became dependent upon it. I never saw how its acts were capable of readjustment, or how the question now before us would be other than the simple issue between Grant and Greeley. On this I concur with the instinctive sense of our people that a change is necessary in the Federal administration. It is rarely, if ever, possible for a party in office to reform itself by the internal force of its best elements. We must have a better state of things in national, State, and municipal government, and a higher standard in the publie mind by which oficial men will be tried and to which they will refer in their silent meditations and in their actions, if we would preserve anything of value in our political system. But I am getting beyond the limits of my time.

"In haste.

$$
\text { "Truly your friend, "S. J. Tilden." }
$$


"Private.

\section{A. G. TILULMLAN TO TILDEN}

“United States Sexate Cifamber, Washington, Aug. 20, 1872.

"Mr bear 'Tilden,-There is a rumor here that O'Conor is willing to accept the nomination of Blanton Duncan's Lonisville convention. If you have any influence with him I pray you to exert it to prevent his doing so. It is as hard for ne to support Greeley as it is for any man I know. But, being compelled to choose between him and Grant, I am satisfied that we ought to support him - not for his own sake, but because it is the only mode left to us to break the radical organization. I have a very high opinion of O'Conor, and would be much distressed should he give the use of his great name to the Louisville movement, which is wholly in the interest of Grant.

"Please write to me at Columbus, Ohio, where I will be in a few days.

$$
\begin{aligned}
& \text { "Yours truly, } \\
& \text { "A. G. Tilurman." }
\end{aligned}
$$

\section{IIORATIO SEYMOUR TO TILDEN}

“Utica, Oct. 3, 18\%?.

"Mr dear Sir,-I enclose a draft for $\$ 5239.34$ to pay my note and interest. Please to send it to me by mail. I an very much obliged to you for the accommodation. How does the canvass go? I am not able to work nyyself into any heat about it. I grow old very fast. Then, too, it is harl to go out to speak for Greeley. His abuse las been so gross. As facts stand, I think it was wise to put lim up, and I can see my way clear to rote for liml, as he ean be made of use in driving negroes ont of oflice; but it is hard to speak for him. But for you and Kerman I would not move this fall. As it is, I will do what I canl.

$$
\begin{aligned}
& \text { "Truly yours, \&c., } \\
& \text { "IIoratio Sermour." }
\end{aligned}
$$

WIIY KELNAN WAS NOMINATED FOR GOVERNOR

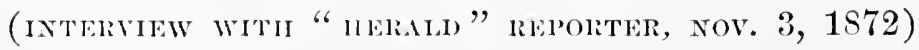

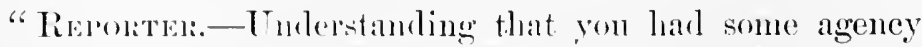
in the nomination of Francis lielnam as the Demoeratic and Liberal Republican candidate for Governor, I have 
called to make some inquiries about it. Will Mr. Kernan be elected?

"Mr. Tilden (smiling).-- You remember the old adage which says, 'You can't tell who is Governor till after the election'? But at the risk of violating that, I will give you an opinion. I feel very certain that Francis Kernan will be the next Governor of the State of New York.

"Reponter.- - Are you willing to state the motives for" nominating $\mathrm{Mr}$. Kernan?

"Mr. Tilden.-I am perfectly willing to state my motives, so far as I had any ageney in the nomination. Mr. Kernan will be 'the right man in the right place.' It is scarcely possible to find a man to whom the public interests can be so safely trusted. He is in the meridian of life and the maturity of his powers. He has acknowledged abilities. He has led a distinguished carcer as a lawyer. He possesses large knowledge and experience of public affairs, while he scarcely ever held office. Tle has inspired universal confidence in his most absolute integrity, and enjoys the esteem and affection of the people of the central portions of the State, and of all who know him everywhere else. Every circumstance about him conspires to assure his singleminded fidelity to the duties of his great trust.

"In the first place, he has a high standard of public conduct. He is imbued with the traditions of the best days of the Democracy. Like Jefferson, he would not attempt to increase his fortune, even by legitimate methods, while in public life. Like Silas Wright and Flagg and Marcy, he wonld not only be pure himself, but would disdain to use impure influence-impure methods or impure men for party objects. His ideals are all lofty.

"In the second place, he is not over-ambitious. He does not aim at a permanent public life, but to serve out his term and return to the congenial pursuit of his profession.

"In the third place, he is totally free from all ambiguous associations. He stands on no 'ring.' He owes nobody anything for political favors.

"Here are reasons enough, and good ones, but not all.

"Reronter.- What were the others? The Republican newspapers say that one was that Mr. Kernan is a Catholic, and that you advised his nomination on that account.

"Mr. Tilden.- There is not the slightest truth, or resemblance to truth, in that story. But I will speak of that 


\section{LETTERS AND MEMORIALS OF SAMUEL J. TILDEN.}

subject presently. The other reason is the connection Mr. Kernan had with the reform movement last year.

\section{"Cily Frouds.}

"The discovery of frauds by certain eity officials happened just as I was allont leaving the eity to spend a week in the country. On the eve of my departure I had an opportmity of cross-examining a gentlentan who had the confidence of the tinancial men and taxpayers of this city, and who called on me with a letter from a distinguished philanthropist. I beeame satisfied that the revelations were substantially true. Mr week's reflections in the comtry resulted in a determination to attenpt to carry ont that system of measures in which I have heen ever sinee engaged; but some co-operation was indispensable.

\section{"Ternan and O'Conor.}

"The first man I sought was Francis Kernan. After much telegraphing I fomd him attending comt in Albany. I went there to meet him. It was on the fourth day of Angust, 1871. He was about to leave for the seashore to attend a sick relative. I gave him the documents. I submitted to him my views as to what ought to be done, and arranged for a further conference on his return. On that occasion he gave me assurances of his full and cordial cooperation, which I ever afterwards received. He was to me the one necessary man for a contest in the State convention. His conrage, his independence, his tact and eloquence in debate, his popularity and weight of character were all needed.

"I next someht C'harles O'Conor. I desired his eo-oper:ition in a different department. His great renown as a lawyer, his mmatehed resourees in a professional controversy, his lofty independence, and his high sense of public duty made him invaluable in many things which were necessary in orter to achieve an overthrow of the eorrupt dynasty which then ruled our great metropolis and to purify the arministration of justice.

"Now it so happened that both of these gentlemen are Americans, born within this State; that they are both sons of exiles, for the sake of liberty, from Ireland; that they are both of the Catholic religion. Mr. Kernan's ereed had nothing more to do with my desire for his nomination for 313 
Gorernor than it had with my seeking his co-operation, or Mrr. O'Conor's co-operation in the reform measures. The only mode in which the question of crced came to be discussed with reference to Mr. Kernan's nomination was afterwards, when, notwithstanding his eminent fitness was conceded, it was said that the Republicans would attack him on account of his religious opinions. Every rogue in the State became greatly troubled on the subject. Every member of a corrupt ring, by interest, was opposed to him and thought that his nomination would eliminate the Protestant vote. I think they could have forgiven his religion if they could only have ceased to fear his honesty. For one, I was not disposed to concede much to such an objection. I never said anything about Mr. Kernan's religion except to defend him. I should have been as much in favor of his nomination if he had been of a different creed. Mr. Kernan is totally free from bigotry. His liberal views on every subject of sectarian controversy are on record in his speeches and in his conduct. In exercising the powers of an official trust his just and equitable character would be an impassible barrier against partiality towards any class to which he should himself belong. Are you ready to adopt the principle that no man, however superior in merits and qualifications, who is a Catholic, shall be eligible to high public office in this great commonwealth of freemen and equals? Such a

\section{"Proscription}

is not only unjust, but it is unwise and self-destructive, with reference to the interests you wish to protect. If your apprehensions were anything but imaginary, you direct them in the wrong quarter. Ambitious politicians seek to win those classes with whom they have no natural relations. It was not Southern men, like Washington and Jefferson and Jackson, who conceded most to slavery; it was Northern men, like Pierce and Buchanan. A Protestant American demagogue-and particularly if he had once been a Know-nothing - would do things to eatch votes or win popularity among a class which a Kernan, an O'Conor, or a John Kelly would reject with disdain.

\section{"City Reformers.}

"New York is a cosmopolitan city. According to the census of 1865, rather more than three-fifths of the voters 
were naturalized. In the other two-fifths are included the sons of naturalized citizens. How reform in municipal artministration or good govermment in the eity is to be worked out by a moral proscription of the forcign voters or of the religions belief of the most numerons class of them, it is not easy to see. Every such effort is caleulated to band them together in a compact mass. Large numbers of them joined in the reform movement of 1871 . If among their classes, or among Americans descended from them, spring up citizens foremost in all the commmnity for talents and virtues and devotion to our Anerican ideas of govermment and soeiety, I wonld not challenge the honorable pride they awaken in those of common origin. I share that pride in such men as Kernan and O'Conor. I wonld not weaken any power of leadership which the natural sentinents of humanity may give them in these numerous classes. I would rather see it stronger than it is in men like these, who wonld never seck to create any class influence, and would never abuse any influence, but rather exereise every power as a trust for the public good. I had oceasion, after the election last year, in frequent addresses on municipal reform, to lament the apatly of many of our citizens whose reproach it is that while by pecmiary independence and leismre and all the legitimate elements of a just and honorable public influence they selfishly abdicate their power of leadership in the affairs of our great metropolis. Wherever a man appears in the conmonwealth who is without venality or the inferior forms of ambition, but from an elevated sense of his duty as a citizen of the commonwealth, he onght to be encomraged and his natural elements of inflnence respected and cherished.

"It is too late in the day to revive the spirit of the native American or Know-nothing parties. The only purely American stock which remains on this entinent is the whole popnlation of the Sonthern States, who are now muder the earpet-bag govermments, upheld by the banded masses of rogues and the influence of the Federal governments and affiliated with the Republican party. In the North we are one-third enicrants of the last twenty-five years or their children. The great migration of the last quarter of a century is the most renarkable in the world's history. It has exercised a controlling power over every important event of our national progress. In that period about seren mill- 
ions of people have come to our Northern States. I had occasion some year's ago to analyze the character of that immigration. I found that it contained just about twice as many male persons between the ages of 15 and 40 as our resident population in 1860 . In other words, it contained the population of the virile age equal to that of fourteen millions of our average people. It is that influx which has created our great cities, which has built our railroads and furnished them business, and which has prodnced the immense growth of our Northern States in population, wealth, and prosperity. It is that influx which overturned the equality of influence between the North and South in the Federal government, and stimulated both sides to the measure that led to the Civil War. It is that influx which would have given the North predominance if the war had not happened, and which gave it the rietory in the conflict of arms, abolished slavery, and will at last fill the Sonth with communities like our own.

"This is the state of things. Who could alter it if he would? Who dare say that, on the whole, he would alter it if he could?

"We must, then, avoid all those eivil and social revolutions, work out as best we may the problem of self-government formed on equal and universal suffrage. Te can only do so on the large, liberal statemanship on which we began, and never by going back toward the dark night of proscription and bigotry."

\section{TILDEN TO MIRS. CASSIDY}

"New York, Feb'y 22, $18 \% 3$.

"Dear Mrs. Cassidr, - I regret that any delay should take place in sending you a statement of the results of the investment made by me for your benefit. But the computations were somewhat long, and needed either help or instructions from me to enable Mr. Smith to complete them, which, until now, I was not able to gire.

"I had hoped before this time to see you and be able to say that, if there is anything in your affairs in which I can offer you suggestion or counsel for the benefit of yourself and your little ones, I shall be glad to be of selvice to you.

"About the time - indeed, a little before I reed. the $\$ 10,000$ remittance - when Mr. Cassidy had told me it 316 
would be sent. I invested some $\$ 1.5,000$ for you. I sold enough the other day to pay the balance due ne for allowances.

"The investment has gained some $\$ 1700$, lesides interest compounded and quaterly. The stome would have sold for $5 \mathrm{per}$ cent. more last rear, which would have been $\$ 750$ additional.

"But investments gencrally show abont that difference; and if you continne to want such an investment for income, it ean now be made adrantageonsly.

"The Cleveland and Pittshmes stock is alwut:; 1/2 per" cent. lower, and rields the same ineome.

"Well-selected gold-interest 7 -p.-c. bonds, if bought at s.) or a little nuder, will give a larger ineouse. 'They should be selected with eaution. Now, three courses are open: sold.

"1. If you need the money the stock can at once be

"2. The stock can be transferred to your name if you do not wish to elange the investment. In that event, it had better be put in your name; for the motive to keep the account open has ceased.

"The stock is perfectly safe as ean be-gives quarterly dividends, and is free from all incone tax, and I think from all personal taxes in this State. The dividends have the security of the great earnings- $\$ 1,750,000$ now above the cent, and the gnaranty of the Penm. R. R. C'o., with its $\$ 65,000,000$ of capital, paying ten per cent., and worth 120.

"But, no doubt, some bond conld be found that might pay a little more. If Mr. Cassidy had lived I intended to change to something which would give more ineone, though I think I was rather more cautions in doing it than he inclined to be. For, after all-especially with a lady-eertain seeurity is the first consideration. We are doubtless now, as we have been for several years past, on a gratually receling seale of values, in which the attempt at large profits inrolves more risk than it did at an earlier period.

"I write hastily, but thus fully that you may know the whole situation. Consult with your advisers, and let me know your wishes.

"T remain, Dear Mr. Cassidy, "Very truly pour friend,

"S. .J. 'T'IL,WEN." 
TILDEN TO N. W. P'ARKER

“New YoRk, March 11, 1873.

"Mr DEar Sir,-I have been waiting mutil something should turn up cheap enough and, at the same time, safe enough to warrant the reinvestment of your money. There are gold-interest-bearing bonds at about $90-7$ p. c.; but I wanted something cheaper. I sometimes hesitate about taking for you what involves so much reliance on one's own judgment as is necessary, where you buy securities new and not well established in the market.

"Some time ago I bought 50 bonds on two railroadsnow consolidated in Texas. One is the Houston and Great Northern R. R., the other the International R. R.

"The bonds are $\$ 16,000$ per mile, and many of our best business men have invested in the stock, which is issued at $\$ 16,000$ per mile. I think the lines likely to be productive, and the investment is managed with a cautious and conservative spirit. I gave $821 / 2$ and the acerued interest for these bonds. I will let you have enough of them to come to your money and interest while it has been in my hands at 7 p. c., tho' I generally have a considerable sum lying in lank at 5-say, 40 or $50,000 \$$.

"We sold 6 of your bonds, which gave 6 per cent., or $\$ 360$ in gold.

"By taking off one conpon-if you can wait-the money and interest would buy about 7 of these bonds. That would give 490 in gold, or a gain of 130 a year in gold.

"Your money, aceording to the a/e sent you, was. $\$ 5,334.46$

Int. to Mar. 14.................. 190.86

" $\Lambda$ s my youmg man has computed........ 5,525.32

Int. to July $1 \ldots \ldots \ldots \ldots \ldots \ldots \ldots \ldots \ldots \ldots 1$

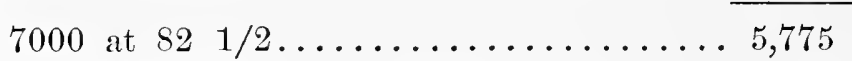

Deficiency $\ldots \ldots \ldots \ldots \ldots \ldots \ldots \ldots . \ldots \ldots$

"Take off 2 of the coupons-making the other begin to run July $1 . \ldots \ldots \ldots \ldots \ldots \ldots \ldots \ldots . . \ldots$

Surplus ............... $\$ 6.23$

"I would like to have you inquire into the matter if you 318 
incline to do this, so as to act as much as possible on your own judgment. If you wish to cone dewn here I will be happy to consult with you and put you in the way of making up an independent judgment.

"If you ineline to something more current you ean buy Cleveland and Pittshurg stock - which ean be eonverted at any time into money; but it will only give you 7 p. c. enrrency on 90.

Very truly yours,

"S. J. Tildons."

WM, M. EYARTS TO TILDEN

"New Yonk, June 17, '\%8.

"Mr DEAR Tildex,-I send you letters:

"1. Mr. Forster, a nember of Parliament and of the present Cabinet. A strong friend of ours through the war and in keeping up the treaty of Washn. during the last year's storm.

"2. Lord Houghton, formerly member of H. of Commons as Rich. Monekton Milnes, an author and society man, friend of Am. polities, ete.

"3. Sir Robt. Tusk, an excellent man and lawyer, now on the Queen's beneh. He was our counsel in the Alexandra ease when $I$ was out in $1568-4$.

"4. Sir Jno. Rose, of Morton, Rose \& Co., whom you know about and probably know.

"5. Mr. Wilkins, a barrister, who has been in this country and is a very capital fellow.

"So much for an hour's work to-night. "Youl's very tiuly,

"The ILon'ble Saml. J. Tilden. Wi. M. Evarts."*

In the summer of $1873, \mathrm{Mr}$. Tilden, for the first time, visited the Old World. While there he sent the following note, addressed, I presume, to John Kelly, then supreme in Tammany IIall. In this assigning reasons for his mistrust of the Republican party, the organization of which was contemporaneous with the commencement of the Civil War of 1S60-61.

* Mr. Tilden spent most of the summer of 1873 in Europe, his first visit to the Old Worli. He bore with him the above enumerated letters of introduction from Mr. Evarts. 
KEY-NOTE OF FEDERAL POLITICS IN 1873

"In the sixteen years during which it will have been in possession of the govermment at the expiration of the present Presidential term, all the evils which eall so londly for redress have had their origin, their persistent and daily growtl.' Nearly all its thinkers, speakers, and writers, its active intellect and its power of leadership are imbued with strong government theories of so extravagant a character that even Hamilton would have disowned and doubtless would liave condemned them. The classes who desire pecuniary profit from existing governmental abuses have become numerous and powerful beyond any example in our country. The myriads of office-loolders, with enhanced salaries, and often with illicit gains; the contractors and jobbers; the beneficiaries of congressional grants of the public property or of special franchises; the favored interests whose business is rendered lucrative by legislative bounties or legislative monopolies; the corporations whose hopes and fears are appealed to be the measures of the government; the rapacious hordes of carpet-baggers who have plundered the impoverisherl people of the South at least ten times as much as Tweed's Ring did the rich metropolis, and whose fungus growth is "intertwined with the roots of the Republican party; all these classes are not only interested in perpetuating existing evils and existing wrongs, but they are the main agencies and instruments by which that work is done."

This is the key-note of Mr. Tilden's view of our Federal politics in 1873. Unhappily, there is nothing in this statement upon which we can boast to-day of any considerable improvement.

\section{MR. TILDEN RESIGNS THE CIIAIRMANSHIP OF THE DEMO- CRATIC STATE COMMITTEE*}

"Geneva, in Switzerland, Aug. 1873.

"Mr denr Sir,-As I shall not be able to return home in season to take part in the political canvass of this fall, I

* Mr. George W. Smith, Mr. Tilden's private secretary, informs me that, according to his recollection. Mr. Tilden did not cease to be chairman of the State committee until he was nominated for Governor in 1874 . 
desire through you to request the delegate to the State convention who will be chosen from ny district to say for me that I decline a re-election as member-at-larege of the State committee and as its chairman.

"What the comntry now needs in meler to save it is a revival of the offeresonian denuelace, with the principles of govermment aml rules of administration, and with the high standard of ofticial morality which were estalblished by the politieal revolution of 1800 . At that tine the infant institutions of the repmblic wore imperilled by the same evil tendencies which have to-tay attained a landere development. The demoralizations of wall-al spirit of gambling adventure, engendered by false systems of pullic finaner; a grasping centralisn, alsorlonge all functions from the local anthorities, and assuning to antrol the industries of individuals by largesses to favored rasses from the public treasury of moneys wrung from the body of the people by taxation-were then, as now, characteristies of the period. The party which swayed the govermuent, thomgh embareing nany elevated characters, was dominated, as an organization, by the ideas of its master-spirit, Alexander IIanilton. Ifimself personally pure, he nevertheless believed that om American people must be governed, if not by foree, at least by appeals to the selfish interests of classes, in all the forms of cormpt influence. I recently met liere-in the birtlplace of Albert Gallatin-a son of that great man, and himself a distingmished American. Speaking in the light of the unsullied traditions of that day, ats woll ats of its pulblic history, he sail that the joblery and eorruption and haxity of official morals were as great, proportionaly, then as now. If this be a true julgment, the reaction which was effected and which gave us half a century of enmparatively pure administration is an eneomracencent that oflicial morals and public life may be again lifted from degradition. As the means of the reaction of 1800 , Thomas Jefferson fomded and oreanized the lemocratic party. Te set up anew the broken foundations of erovermunental power. Ile stayed the advancing centralism. He restorerl the rights of the States and the localities. The repressed the medtling of government in thre eoncerns of privatu lunsiness, remitting the management of the imlustries of the entutry to the domain of the individual judgurent and conscience. ITe not only brought the administration into conformity with principles 321 


\section{LETTERS AND MEMIORIALS OF SAMUEL J. TILDEN}

which lessen the oceasions and the motives for corruption, but he enforeed, by precept and by example, purity and disinterestedness in official life. He refused to appoint relatives to office. He declined all presents. He refrained, while in the public service, from all enterprises to inerease his private fortme.

"The immense ascendency over the public opinion of the country aequired by $\mathrm{M} r$. Jefferson-the complete trimmph of the party he formed and led, the aceeptance at length by the whole people of him as the highest political anthorityshaped the course of government in the United States for half a century. That period will stand in all history as the golden age of the republic.

"The reformatory work of $\mathrm{Mr}$. Jefferson in 1800 must now be repeated. Organizations and names are important only as they are available for the result. Every patriotic citizen, sincerely desirous of reform, should discard all prejudices and accept the benefaction from any source which is capable of providing it.

"But it is quite clear that the Republican party now swaying the administration, althongh it embraces large numbers of honorable and patriotic eitizens, is, as a whole, incapable of this specific mission. In the sixteen years during which it will have been in possession of the government at the expiration of the present Presidential term, all the evils which eall so londly for redress have had their origin, their persistent and daily growth. Nearly all its thinkers, speakers and writers, its active intellect and its power of leadership, are imbued with strong-government theories of so extravagant a character that even Hamilton would have disowned and doubtless would have condemned them. The classes who desire peeuniary profit from existing' governmental abuses have become numerous and powerfill beyond any example in our conntry. The myriads of office-holders, with enlanced salaries, and often with illicit gains; the contractors and jobbers; the beneficiaries of Congressional grants of the public property or of special franchises; the favored interests whose business is rendered lncrative by legislative bounties or legislative monopolies; the corporations whose hopes and fears are appealed to by the measures of the government; the rapacious hordes of carpet-baggers who have plundered the impoverished people of the South at least ten times as much as Tweed's Ring did the rich 
metropolis, and whose fingus growtl is introtwined with the roots of the Republican pirty; all these classes are not only interested in perpetuating existing crils and existing wrongs, but they are the main agencies and instruments ly which that work is done. They furnish organization, they supply numerous partisans who derote themselves to electioneering while the honest citizens are compelled to earn their daily bread by the sweat of their brow; they contribute and aggregate vast sums of money to be expended in conducting party canvasses, in influencing the elections and in corrupting the roters; sums which no number of disinterested citizens could furnish if equally unscrupulous in the methods of political influence. For the first time in our national listory such elasses have become powerful enough to aspire to be in America the ruling elasses, as they have been and are in the corrupt societies of the Old World. Ther threaten to reproduce here a state of things often found elsewhere, in which the governmental machine, with its allies and dependents, is capable of setting itself up against and over the whole mass of unorganized citizens who follow the avocations of private life. These classes eompletely possess the organization of the Republican party. They have absorbed the Republican party. They are, for all practical purposes, the Republican party. They make its nominations; they shape its measures, they preserve its policy. Individual dissenters who preserve the original traditions of American free govermment there are, but their voices are not heard; they are generally paralyzed; they are always powerless. Ilitherto no Democratic minority has been formed capable of exercising any practical power. No internal remely ean cone for a discase which has incorporated itself with everything vital in the political body. It is too late to cut out the caneer without killing the patient.

"In the nature of the case, the remedy can come only from an opposition which shall grow strong enough to turn out the present existing administration and take its place. In such an opposition the Democratic masses must contribute a large element. 'They embrace three and a half or four millions of votes, and are of thenselves within five per cent. of a majority. They contain nearly all the thinkers, speakers and writers, all the trained statesmen who adhere to the traditions of Jefferson; and while individual mem- 
bers have been not mstained with the crrors of the times, the body, as a whole, is sound; and a majority is sure to declare for the aneient faith of Jefferson and Franklin and George Clinton and Samnel and John Hancock.

"In the part I have borne in the administration of the Demoeratic party of the State of New York-now closedI have aimed at three things:

"1. To lead on public opinion in favor of the original ideas of the Jeffersonian democracy and in support of such current measures as secured valuable reforms.

" 2 . To terminate a degrading strife in which they enlisted themselves; in comparing the leprous spots on their respective sides, and practically declared that the word only was wanting to ineite an honorable emulation in which they should seek and apply effectual remedies and the public mind stimulated to reform.

" 3 . T'o prepare the Democratic masses to act their part in a general movement for reform in all the governmental institutions of the comntry." (Cotera desunt.)

\section{TILDEN TO JOHN KEI.LY}

"Geneva, in Switzerland, Sept. 6th, $18 \% 3$.

"Mr dear SiR, - As I shall not be able to return home in season to take part in the politieal canvass of this autumn, I desire you to say for me to the State convention that I decline a re-election as member-at-large of the State committee and as its chairman.

"It is a satisfaction to me that I surrender to the Demoeraey of the State of New York-now comprising nearly half a million of voters - the trust with which they have so long invested me, at a moment when the pronouneed movement for reform and better govermment in which I felt it my duty 'to follow wherever any dared to lead, or to lead wherever any lared to follow,' has been orerwhelmingly sustained by the Democratic masses, until there is no longer a whisper of dissent; and at a moment, too, when, with nominations responsive to this growing popular sentiment, the prospects of snecess at the approaching State election are so anspicions.

"With much esteem, I remain,

"Very truly, your friend, "S. J. Tildden." 
MAYOR HAVEMEYER S MESSAGE ANNOUNCLNG THE HWTII OL AZAliAII C. FLAGG

"November, $18 \% 3$.

"It is with profound sorrow that I communicate to you officially the intelligence that Azariah C. Flagg died at his residence in this eity on the evening of the $24 t h$. At the close of the next month it will be fifteen years since the public eareer of this eminent eitizen was terminated. In that interval, totally bereft of eyesight, but with an intellect clear and strong, and a spirit courageons and serene, he has lived in complete retirement, fulfilling some private trusts, and ever thonghtful of all public interests. At last, when a few days would have completed an age of eighty-three years, he has passed from among us.

"There are peenliarities in the public eareer and public character of $\mathrm{Mr}$. Flagg which make it specially fit that the people of this State, and the people of this eity, should pause a moment in their busy life to render a conspicuous lomage to him as his mortal remains pass to the tomb.

" Te was born in Orwell, in the State of Vermont, on the 2Sth of November, 1790. 'In carly youth he migrated to Plattsburg, in this State. He had an honorable share in the defence of that place against the British invasion in the war of 1S12-15. He sought a frugal livelihood as editor and printer of the Plattshurg Republican, a Democratic newspaper. In November, 1522, he was elected by the friends of Clinton to the Assembly. TIe sorved in that body with distinction during the sessions of 1828 and $182+$. In Febluary, 1S26, he was elected Secretary of State by the Legislature, and held that oflice until Jim., 1833, when he was elected Comptroller. He held the latter office mintil 1 ss.9. IIe was restored to it in 1842 , and continued to loold it until the elose of 1s+7. His official service consisted of two years in the $\Lambda$ ssembly and 19 years in the Camal Boad, ats Comptroller, as Secr. of State; and his moflicial service was even more valuable during the three years from 1839 to 1842. His career in State administration may be comted as 2.5 years.

"In this carcer of a quarter of a century in the administration of the State, Mr. Flagg's merit and renown will be found not in the catalogne of the great offices he held, but 325 
in the wise measures and honest policy he originated or maintained-in the ability, vigor, and courage with which he pursued the right and confronted the wrong, and in the great fact that he invariably wielded official power and party leadership for the cause of good govermment, for purity in legislation and in administration; that he used these great influences, not for the purposes of individual ambition or personal gain, but exclusively and undeviatingly, for the public good; that he contributed very largely to keep up and to elerate the standard and the tone of official and political morals in both parties and in the whole public during this. long period in the greatest State of the Union. Mr. Flagg was united with Martin Van Buren, whose organizing genius and masterly abilities created the association; with Silas Wright and William L. Marcy, also statesmen of the first class. They were all men of probity, frugality, and personal virtue, and they drew to their side similar characters in all parts of the State. Mr. Flagg made the State finances his specialty; and surpassed all his associates in enterprise and courage, though he may not have equalled them in general attainments, and was often the most effective leader in this State.

"In the six years from 1853 to 1859 , Mr. Flagg served as Comptroller of this city; and although he did not attempt any political leadership, his career was distinguished by the fidelity and firmness with which he resented all invasions of the municipal treasury; and his persistent and unwearied exertions in this service no doubt hastened the malady by which, at nearly the allotted age of man, closed forever his vision upon the light of the heavens.

"It may safely be said that the history of the country affords no equal example of a life devoted for so long a period with so much affirmative activity, and with so much ability and skill, to the abstract cause of good government in the civil administration of the community in which Providence had cast his lot.

"At a period when the people everywhere are feeling how much they need such virtues and such services, we ought to signalize our appreciation of so remarkable an example, if only as an incentive to its imitation."*

* This address was found among Mr. Tilden's papers, and was written by him at the request of the Mayor. 
"Dear Menri,-I have but a moment. I am pressed on every side with urgent denands.

"There will be no use in vour asking me for any further aid, unless you ean make up your mind to abandon your pride and imperious will, and eone to terms which I liave so long advised for your own good and which I ought long ago to have enforeed for my own peace and saffety.

"I seareely like to repeat my ideas, because I frequently hear, through indirect elamels, of rour complaint that I go back 18 years, and so you don't wish to talk with me.

"Now, I never have reenred to painful topies merely to wound, but only to try to impress the lessons which you ought to have derived from your own experience, but which you never would adnit to me, and which you have never acted on. If it is hopeless to expect that you will correct errors-if you are too prond to admit then-what resouree have I but to keep that whicl is [left] out of your power? What hope is there that anything I ean do will be of any permanent use to you or your fanily? What can I do but turn away my thoughts from a man-this affair, which has cost me more anxiety, trouble, hazard of my own affairs and of health than everybody and everything in life-who grabs anything of mine le ean lay his hands on withont asking me, never consults me about restoring it, and thinks it right to do just as he plases alont incurring new expenditures and operations in preference to paying his creclitors, whom he does not think it necessary to consult, or, indeed, to have any rights but to submit to what he, in lis supreme good pleasure, elionses to do.

"In prudence and in morality you have nuclı to do to regain my good opinion. The first thing is to see and admit your crrors. 'The next is to show signs of amending them.

"1. An ordinary creditor would have a right to know, frankly and truly, the situation of a debtor. Still nore so would a man who was aiding as a matter of favorfriendship or affection.

"In twenty vears T have been able to get nothing from you which was not wrung out, resu when I was nikking new advances at great sacrifices. Then ats seanty as possible. I never had any information about your Michigan transac- 
tions. I never have been able to get information in season to adrise about the shaping of your plans.

"You have seemed to think that everybody ought to accept your own riew of your affairs-allow you to embark in new undertakings money justly due to your creditors without their consent or knowledge-and that it was almost a piece of impertinence for them to wish to know anything about their own money."

\section{S. S. COX TO TILDEN (TELEGRAM)}

"To S. J. Tildpen,

"Washington, D. C., Dec. 1, 1873.

15 Gramercy Park.

"Should we Democrats vote Fernando Wood and back pay?

"S. S. Cox."

\section{TILDEN TO S. S. COX (TELEGRAM)}

"Telegram received while you are already acting. But State convention, which is higher authority, had before instructed you.

\section{"S. J. TILDEN."}

\section{W. E. HAVEMEYER TO S. J. TILDEN}

"New York, Jan'y 10, 18\%'.

"Mr dear Tilden,-I have been invited by the present Common Council to present on the 14th inst. to the family of Horace Greeley an illuminated album ordered by their predecessors. As you were intimately acquainted with him, and know a good deal more of his history and character which it may be appropriate to refer to in presenting the testimonial, you are able to embody them in an address to accompany the presentation much better than myself, and I hope you will find time to prepare it.

"In doing so you may say for me that I had no personal acquaintance with him, never spoke to him but once at a little sociable at Doct. Bostwick's 25 years ago, had no political relations or affinities with him, but recognize in the general esteem in which he was held by a large portion of the community for so long a time as an honest journalist, that a more intimate acquaintance might have found us in 
closer relationship than probalyly either of us felt ourselves called upon to atknowledge. I will send for it on Monday morning at your house, as I know you will take the little trouble it will oceasion you to oblige me.

- Yours truly,

" IV. F. Havemeyer.

"To S. J. Tilden, Esq."

TILIUEN TO MISS MORSE AND MISS D.ILY

"Saturday Moring, A pril \&, 18\%?.

"Denr yourg Lamies,-Miss Daly, when I had the pleasure to see her-where her like are not always found -at home, suggested to me to join in some little floral tribute to Nilsson before the close of her present engagement. With my usual docility I aequieseed, and that is all which has cone of it. I have no guidance, and am in danger of being a delinquent.

"To-day is the last, if not the best oecasion. But the roschuds would spring as fitly out of the rugged cleft of the storm-beaten oak as from me, while they would form natnrally and eome gracefully from the representatives of the springtime of womanlooil.

"Shall I mention another circumstance in a postscript$u m$ ?

"I am suddenly called to attend an auction sale of a railroad in Jersey City at 2 to-day, and may not see the Academy.

"I hope, therefore, you will undertake the disposal of what accompanies this note.

$$
\begin{aligned}
& \text { "Very truly, } \\
& \text { "Yours, se., } \\
&
\end{aligned}
$$

"Miss Morse and Miss Daly.

"Sal. Morn., A pril 4, 1874."

WIIELLEL II. PECKIIAM TO TILDEN

" 18 Watr. St., Mar. 9th, 187\%.

"Mr DEAR Sir,-I have yours of 7 th, in all of which I acquiesce except the following sentence: "You are fill of your own business, and so are not able to meditate beforehand what you should do.'

"Now, I am full of my own business, but this is part of 329 
my business, and so long as I have anything to do with it shall and does receive all the 'meditation' that I ean eonceive may be of advantage to it.

"I have seen Sendder, have also arranged to earefully re-examine the figures in respect to the men to whom you allude.

"Sendier is to communicate with his former correspondent and see him, and do what can be done to bring us together.

"I ean get an attachment against the men to whom you refer on evidence we now have, and with the testimony of either of the men whom we propose to get ean recover ; perhaps without such testimony, but I have not sufficiently examined the figures to say so yet.

"I saw Mr. O'Conor yesterday. He is anxious that nothing be done until the last remedy bill be passed.

"Mr. Pelton, when writing me, said that copies of the two bills already passed-attachment and eriminal-would be sent to me. They have not come.

"Will you be kind enough to ask him to send them to me?

"Now, as to Connolly:

"He wants to settle civil claims only-not criminal. $\mathrm{He}$ offers $\$ 400$ th. Will give, I think, $\$ 500$ th. It won't let him come home, for the indictments still stand. I think Mr. O'Conor is not in favor of it. I am, $i$. e., of this particular settlement as to this man. I think that it is all we conld get by litigation. II is property has undoubtedly shrunk, and doubtless he has been blackmailed to a large extent. I ean have the whole matter closed and money paid in thirty days. What do you think of it?

"I think if the general voice shd. be in favor of a settlement Mr. O'Conor would aequiesee; but I merely so infer.

"As to the mountain, ete.: Why, Mahomet will go soon. "Yours Truly, "Wineeler M. Pechinam.

"Hon. S. J. Tilden."

ABOUT PRESIDENTIAL CANDIDATE IN 1876

(REPORT OF A CONTERSATION With GOV. TILDEN IN 1874)

"Your correspondent not having the liberty of an interview, nevertheless had the privilege of a conversation, not at all private, worthy of public consideration. 
"His Excellener was reminded that he conld not he an molservant spectater of the eircmustanee that the leaters of both political parties are discussing Presidential questions and canvalsing the claims of opposed camblitates in both. He promptly responded that that concerned him the least whilst he had serious duties to perform. The Presideney, he said, is not strictly before the people at all in this camvass. 'They are to eleet lecrislaters who shomld inprove the laws, and executive State oflicers to administer the sane. A constitutional anendment contemplates cutting off extra compensations to contractors, but it does not prohilit the Legislature from charging work in the interest 'of the contractor,' besicles anthorizing "the Canal Board' to eancel such (contractor's) contract. 'This shows the vital importance of electing a sound Legislature and a safe Canal Bonard. The practice has been too much to pass laws in the interest of the sinister, the evil, and the profligate clisses; and the same have been administered aceorelingly, mitil the rights and interests of the honest and industrial classes have been greatly ignored and the eommon prosperity well-nigh paralyzed. The State has just now a far deeper interest in home govermunent than in the national concerns. We need not overlook the frands and extravigances of the Washington govermment, but we shall find on hand full enougl, to do if we arrest and redress the abmses that pervalde our cities, towns, and comties, and particularly the State, for this year, leaving the selection of nembers of Congress and Presidential electors to their proper time another year.

"IIis Excelleney was further reminded that he conld not overlook the fact that the prominence, not to say popularity, of lis administration had led to the consideration of his name in eonnection with the next Presidency, and that some rivaly conseguent upon the agitation of 'hone questions' laad led to the faroring of candidates beyond the linits of our own State.

"His Excellency promptly (and rather nervously") responded that public opinion will be very apt to take care of such interests and issues. He had seen enough to satisfy him that lee who eseapes the eares and responsibilities of public life is far happier than he who enjors its supposed honors and emoluments. Ile could most heartily and trustfully support the superior (dains as they are miscalled) of New York's favorite son and foremost statesman. 
"Of course, this was understood to refer" to Governor Sermour. So his Excelleney was reminded that it was objeeted that he had had his opportunity, and also that our State has had both of the last two chances for the Presideney.

$\therefore$ 'Oh, that is a superficial, if not sinister, view of the case,' promptly rejoined my interlocutor. 'The public no longer cares what State or section candidates come from. They may be taken from one or the other, or both from either, and the people will not care, so long as the men and measures are acceptable. Gov. Seymour was nominated eight years ago against his wishes and his friends', with the tacit if not expressed understanding that he and they were making a sacrifice at the time to a political exigency. The same, pretty much, may be said in the case of the lamented Greeley. New York has no local claims (any more than the "mother of Presidents" of old had); neither has she any local disabilities. But there is no use of discussing these matters, as he said before. We have more appropriate and pressing work in hand. When that is done it will be time enough to bother our heads about other political concerns.'

"His Excellency was badgered a little on the reports of his alleged ill health, but he was disposed to treat it as ' an invention of the enemy.' Yet he expressed jocosely the hope that his own constitution might soon experience a respite from his sedentary confinement, as well as the bad habits of public life."

\section{JACOB S. GOULD TO II. $\Lambda$. TILDEN}

"Rochester, Sept. 5, $18 \%$.

"H. A. Tildonn.

"MY DEAr Sir,- -Just after posting my hasty note to you of the 3rd inst. I met Isaac Putts and went to his office with him. Wilkins, who has been a delegate to the State convention from this eity a number of times, and Geo. Taylor, the Assemblyman of last winter from this eity, was in said office. After a little time, Butts spoke of the convention to be held at Syracuse, and said that S. J. Tilden was the only man that shonld receive the nomination, "and would get it.' Wrilkins was still stronger in his views for Tilden. Geo. Taỹlor said but little, for he is a Lord man 
-the Lords are very still; they do not want W. E. Allen; they wish to keep that court bench just as it is nou. You know why. Allen and Gauson, of Buffalo, will be the only men in the way of S. I. T'ilden. I now think that Erie, Niagara, and Genesee comties will give full delegation for 'Tilden. Livingston, Monroe, and Orleans. Ontario will give part delegation for Tilden. $A$ few days more will show how the eat will jump with the Canal Ring men. They must show their hand soon. I will keep you posted.

$$
\text { "I am, Yours, }
$$

In peneil by Henry 1 . 'Tililen:

"Siml.,-Momlay, 3 o'e. Just received. You see by it how matters stand."

\section{MAGONE TO TILDEN}

"OGnexsibur, N. Y., Aug. 21, 18\%.

"Denr Sir,-Your telegram, kindly inviting me to be present at the meeting of the Democritic State committee to-day, was received. It wals impractieable for me to attend, and I conld not tell where a telegram would reach your. I write now to return thanks for your courtesy in inviting me to be present. I do not share the fears of many of our friends that Governor Dix's personal popmlarity will carry the radical ticket suceessfully through the coning canvass; on the contrary, I believe our prospects good, if we are honest with ourselves and jullicious in. selecting candidates.

"I an opposed to selecting a candidate for Governor from the jurlges of the Court of Appeals. Either Hon. Clarkson N. Potter or IIon. John Ganson would make a fair candidate, but nyy first and last choice is yourselt. My position in your ease is precisely what you know it was at the time, in 1872, our mutual and esteened friend, Hon. Francis Kernan, was talked of as a probitle nominee. Mr. liernan's religions envictions were the first, if not the only objection sugesested by those opposed to his nomination; in your anse the first if not the only objection urged is that your comrageness and sucesstul attack mpon a corrupt ring in omr party will lessen the vote for youl, it leeing always suggested in this connection that the old and corrupt ring 33.3 
still control a large vote, especially in your city. I say away with such abject fears! If our party friends will not support brare, honest men because a ring of plunderers and their retainers may be displeased, then let our opponents succeed, and we will at least escape the responsibility always attending political power. This has been and is my position on the question.

"Respectfully Yours,

"D. Magone, Jr."

\section{ALVA II. TREMIIN TO TILDEN}

"Albany, Sept. 10, $18 \%$.

" $\mathrm{M}_{\mathrm{Y}}$ DEAR SIR,-I am in receipt of your circular and letter which came to hand to-day. Enclosed find a corrected list of working-men as you desire.

"I also assume the liberty of addressing you the following, which please consider confidential. The position of things in this county and the influences which I believe are working against yourself prompt these suggestions.

"The regular commiltees of our city and county will send to the State convention 12 delegates, all able, prominent, representative, and live working-men and Democrats. They are, I think, with good reason, unanimously in favor of your nomination. There will, however, be a contesting delegation from here, made from powers wielded by a county committee which commenced its existence about 't months since, which is being controlled by its president, John McEwen, and supported by the Argus. I think I hazard nothing in stating that in my judgment this last delegation, together with the entire power of the Argus and the 'Canal Ring' here, which support them, are inimical to your nomination and will do all they can to defeat you. The developments which have been watched, and especially these within the last two days in connection with the Liberal Republican convention, I think fully sustain all I say, and even more. The whole of these 3 powers were used to their utmost strength during the last 2 days to drive you from the field and to force the renomination of $\mathrm{Mr}$. Church. This plan was fought against by our delegation and those acting therewith, and to their ingenious and proper management in a great degree is the result attributable which prevented the naming of Mr. Church by their convention. 
The Argus, MeEwen, and their supporters, we believe, are doing all they can to fill up your path. We are disposed to keep it clear and to give you our individual support.

"You are, of comrse, aware that our admission to the State convention is to be opposed as bitterly as it can be by the setme pouers which are named above as being opposed to you. We are therefore very anxions to receive your support in procuring our admission as regular delegates into said convention. 'The self-same persons, we believe, which are massed against us are consolidated agst. you. The success of our delegation will add to your soldiers. Fnowing yon will have much to say in regard to the committee before whom we must appear, I sincerely trust you will see that it is so composed that bolting committee delegations camnot oust those who represent the regular committees from this county, who have aided you in fighting our political battles so ably for the last 40 years. When I can be of further service, please let me know. Shall be happy to acknowledge any attention you may conclude to extend.

Your obdt. servant,

$$
\text { "Alva H. Tremain." }
$$

IIORATIO SEYMOUR TO TILDEN

"Utics, Sept. 11, 18\%\%.

"Mr Desr Sir,-I have been confined to my house for" some days, so that I have not been able to see Mr. Kernan. 'To-day he is ont of town. To-mor'row I shall go to the north part of our comnty to attem the district convention, which I shall get to send me to Syracnse. I have to go thirty miles to reach it, as it is held in a remote corner of om comnty. As I wrote you before, the State his been scomred by your opponents. The State officers are hostile, and every canal official is at work to keep your friends out of the convention. In Oneida we have more than one hundred miles of cinals rmming into all sections of its territory. I shall not be surprised if I encounter a sharp opposition to-morrow. It is not open opposition alone which is to be contended with. Men are put forward who elaim to be your friends who are to be eonvined in due tine that it will not be expedient to nominate you, although they hold you in high regard, ete., ete.

"A high compliment is paid to you by men. who have 335 
schemes when they show that they do not want you in Albany. So far as your fame and honor are concerned, it will be fortmuate for you if they suceed, for the whole press, which will be hostile or silent if you are put into the field, will be full of your praises if it is held that you are too honest to be made a Governor.

"Hon. S. J. Tilden. "Truly yours, de.,

FRANCIS KERNAN TO TILDEN

"UTica, Sept. 12, $18 \% 4$.

"Mr dear Sir,-I came home from Binghamton today, where I have been several days. I see the opposition to you has taken a new phase within a few days. Your opponents are seeking to have you resign in favor of Judge Chureh. I do not think you can now do so with propriety. The matter of a candidate for Governor has been eanrassed for weeks; it has been understood by us all that Judge Church would not take a nomination; there were many reasons why, being ehief justice, he should not vacate the position and leave it to be filled by appointment for a year. Your name has been canvassed, and your friends have taken strong ground in favor of your nomination; now those who have been opposed to you, not your friends, ask you to retire that Judge Chureh may be nominated. In my judgment you should not take the responsibility of this step; the matter has progressed so far that I think you should leave the matter to your friends and the eonvention which is about to assemble. I see no other way out of the matter but in thus acting.

"The delegates in this district were eleeted to-day. The one from the eity will vote for you, and the other's also, as I believe.

"From all I ean learn I think the eonvention will be in favor of your nomination. I shall be at Syracuse Tuesday evening.

Yours, in haste,

$$
\text { "Francis Kernan." }
$$

\section{N. W. PARKER TO TILDEN (TELEGRAM)}

"Hamilton, N. Y., Sept. 16, 18\%\%.

"I am too ill to attend the convention. My judgment is that on no account should you withdraw your name as can- 
didate for Gorernor. Better suffer defeat. Cirenumstances seem to me to require it, and I submit it with my best wishes.

"N. W. Parkek."

TILDEN TO IION. A. MIIDSALL

"New York, Scpt. 19, 1S\%,.

"MY dear Sil,--I take the earliest creasion, on my return home, to thank you for the timely and friendly tone of yours of the 11 th.

$\therefore$ It may he that there is much in the speculations you make as to the causes of the sudden and active opposition to my nomination. If so, it is very foolish. Nothing is gained to an individual and much is lost to a party by forecasting so fiur in advance of time and events. That I never do. Mr. Wriglut once said to me that men who fix their eye on a distant object are apt to fail to see the sticks and stones in the path immediatrly hefore them, and to stmmble and fall.

"The truth is, I' did not come to entertain the idea of taking a nomination mutil the 21st of Aug. Like yourself, I have seen everything. There are no illusions in my mind in respect to public life. I know that peace, content, and happiness are only in a private station; and it is wholly exceptional in me to do what I am now doing.

"I shall be happy to hear from you whenever it may suit your convenience to write.

"In the mean time, believe me, sc.,

"S. J. Tilden."

HORATIO SEYMOUL TO TILIEN

"Utics, Sept. ?0, 18\%\%.

"MY DE.sR Sin,-I have read with pleasure your speceh made at the serenade. It is elear and alle. It was a hetter tine to make it than in the convention, as it would have interrupted its action when all was going on well. But there are reasons why you should not make any, more speeches. If you do you must speak about national affairs, as you camot talk about yourself. This will turn away attention from the points we wish to keep in men's minds. It will also put you into antagonism with many Republicans who are disposed to rote for your for home reasons. As 
matters stand, you can make no speech which will help you with those we hope to gain from the other side. You will also draw upon yourself the fire of journals which are disposed to beat you fairly. I an clear that the true policy is to look after organizations, etc. I will write again soon. "Truly yours, \&c.,

"Horatio Seymour."

\section{P. II. COWEN TO TILDEN -}

\section{(ADVICE VOLUNTEERED BUT NOT FOLLOWED)}

"Cowen's Law Office, No. 15 Town Hall Building, "Saratoga Springs, N. Y., Sept. 21, $18 \%$.

"Mr DEAR SiR,-We have known each other for many years; have passed through many lieated political campaigns together, striving for the same political results; therefore I hope you will not deem it amiss if I write you a short letter. I premise by saying what every one knows-that without the aid of the personal friends of Tweed the State ticket this fall will be defeated by forty thousand majority. Can his friends be made our friends in this campaign? I answer 'yes.' You inquire, 'How can this be done?'

"The object of eriminal punishment in theory and practice, as laid down by all elementary writers, is to reform the offender, to deter him and others from committing like offences, and to protect society. Has not this object been accomplished in the case of Tweed? Gen. Dix, if elected, will not pardon him; will you? If his friends have your promise, when elected, to pardon, will they not put in a half million into a fund for your suceess? Then let them say to their friends in each county that they desire your clection for a purpose, and we have the whole strength of the Democratic party. That will not, perhaps, be enough. Let the temperance men be paid and their organizations sustained by money, and success is certain. Let one man in each $A$ ssembly district be re-elected who will be in the secret and have the desired funds, who will thoroughly work his district-both in getting out the Democrats and taking care of the temperance people-and you have the desired result. You and the reformers can afford this promise. I am not and never was a 'Tweed man - I thonght his punishment just-yet I think he has been confined long enough for all purposes, legal, moral, or political. The 338 
above is a bold proposition; if you think of it, it will appear a just one. But be that as it may, without some such move we camnot carry the State. Excuse me if in writing thus I presume too much.

$$
\begin{aligned}
& \text { "Yours Respectfully, } \\
& \text { "P. H. Coww." }
\end{aligned}
$$

\section{TILDEN FOR GOVERNOR}

(TIE COURSE OF TIE ADMINISTRATION PRESS REVIEWED)

$$
\text { (From the Ncw York "Tribune") }
$$

It is rery much to the credit of the administration journals of the State that, so far as they discussed heforehand the claims and qualifications of the several candidates for the Democratic nomination for Governor, they frankly recognized the fact that the logic of the Democratic professions of reform pointed mmistakably to the gentleman who was nominated at Syracuse on Thursday. Indeed, they almost may be said to have advised and urged his nomination. In doing this we give them credit for rising alove the narrowess of partisanship, and for taking into view the great public benefit to be derived from laving for the candidates of both parties men of distinguished ability and mimpeachable integrity, instead of following the instincts of a petty and mpatriotic selfishness by endeavoring to induce their opponents to weaken and stultify themselves. Mr. Tilden, at no small risk of personal popularity and political influence, and with no conceivalble motive lut a desire for the pulblic good, had fairly revolutionized his own party. In arresting the corrupt and profligate career of the Ring that ruled it, he las contriluted to its temporary defeat. But the movement he led was a suecess, and the party was shrewd enough to discem in the signs of the times the wisdom of assuming the responsilility and claiming the eredit for the reform. They have done this persistently.

It was plain enough to the most casual olsserver that from the moment Mr. Tilden consented to have his name presented as the candidate for Governor of the party to which he had been so conspicuons in adninistering discipline, that party could not reject him without confessing the insincerity of its boasting over what was in so marked de- 
gree his work. Not to have nominated him would have been justly considered a rebuke and a warning to any and all who should hereafter put party success in jeopardy for the sake of putting a stop to public robbery. The administration newspapers which pointed out the folly and danger of such a course deserve praise for rising above the small strategy, hypocrisy, and trickery so common in polities. We have already expressed the opinion that the convention which nominated Mr. Tilden was driven to it by the logic of events and as a consequence of its professions of reform. That the nomination is offensive to a considerable number of the party, who were directly or indirectly disturbed by 'Tweed's overthrow, is an admitted fact; and there was, no doubt, considerable hesitation in the minds of many influential leaders over the question whether, upon the whole, it would be safe to offend these people for the sake of making a consistent record for the party.

As for Mr. Tilden himself, it ean be of comparatively little consequence to him personally now whether he is or is not elected. He has accomplished a great work in his party, has led a great reform, overthrown a powerful organization of municipal thieves, and compelled a recognition of his services more emphatic and pronomeed in the mere form of the nomination than an election could be under any other circumstances. We presume he has not deceived himself with the idea that the administration journals which have heretofore bestowed upon him such copious praise, and have so frankly pointed out to his party his strength as a candidate, have thereby estopped themselves from attacking his principles and his character. As citizens, the gentlemen who eonduct these newspapers are doubtless glad to be assured that, whatever may be the result of the election, the office of Governor will be filled hy an able and upright gentleman of whom they need not be ashamed. As partisans, however, they propose to find whatever joints there may be in his harness and to defeat him if they can. One organ, we pereeive already, after remarking that it does not know positively that if elected he would misuse the power intrusted to him, calls attention to the fact that he has acted as counsel for some of the greatest railroad corporations in the State, and suggests in a wise way that it might be very dangerous at this time to put such a man in the executive chair. Another gives him credit for his services in over- 
throving the Twered ling, lout ardes that he diel not do it at the right time; that he omght to have done it sooner. It does not acense him of dishonesty, but feels compelled to call him a "moral coward." And so they wo. (Of course there will be a great deal of it before the campaign is over, a great deal that is mean and contemptilile and dishonest, but just now we prefer to eonsider the munsual honesty and frankness with which the administration press treated the question before the nomination, and to give eredit for sincerity and independence. When each party commsels the other to nominate its best men, and the andrice is followed, we shall see purer politics and better govermment.

HORATIO SEIMOUL TO TILDEN

"UTICA, Sept. 2.3, 187\%.

"Mr miar Sir,-Can you keep the Tribune from taking ground for Dix? It onglit not to go for lim, as he opposed Mr. Greeley and has milield every act of Grant. When his whole course is latid before Mr. Rieid I think lie must change his views of Dix's character. I shall hurry off to Manlins this week, so that I can get back in time to attend public neetings if they are held. The quiet work of organization should take up the time for two or three weeks.

"I send Mr. Pieree to see yon lexeinse I think he ean put a great number of travelling merehants and tradesmen at work. They go into any part of the State and can learn what is going on. While the regular State committee shonld do its work, you should have in your own hands and under your own direct private control ageneies which will cover the eromel omtside of the old political machinery. If the otlere side do not hold meet ings we shomld not, at the ontset. There are many loarling Repulde's who de not wish to go to work in the harness if they ran keep ont of the canvass.

'I ann, truly promrs, ifre,

"Holicino Sirmouls."

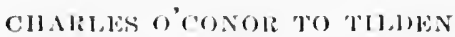

"scpt. 99, 18\%\%.

"Dear Sir,-T wrote Miller a short note [of] congratulation. The reply reed. last evening is herewith. Can you wateh the progress of things and smimmon me 'to the front" 
when the apprehended movement is made in the association? I will eheerfully go to the meeting and oppose it.

"I cannot doubt but that an effort will be made to move the lawyers in Johnson's faror. If it he done a countermovement to stir the reformers against him may be needful, or at least expedient.

"It will hardly be possible to keep the swindler issue out of the campaign.

"In a note from Frank Barlow, recd. vesterday, a decided opinion is expressed that Delafield Smith means to quash the Ring prosecutions.

"It really seems to me that things are ripe for a pounce upon him and the offending majority.

"I have written Miller to print what he pleases, but not to use my name. If it should become necessary to make the pounce just above suggested my name should appear there for the first time. Or at least it should not be worn out in previous skirmishes.

"I was in town yesterday and tried to see Jno. McKeon, but failed. I would go again to-day but for two reasons: first, it rains, and, secondly, the hope of controlling him in anything by friendly advice is always so slight that little inconvenience should ever be suffered for the sake of offering it.

$$
\text { "Y'rs, "Ch. O'Conor." }
$$

\section{GOVERNOR TILDEN TO WILLIAM PURCELL}

"Dec. 8, "\%

"Dear Mr. Purcell,-Will you accept a plaee on my staff, with the rank of Brigadier-Gen., with nominal duties and without pay, as indeed are all the offices, except the strictly military ones? This offer will not interfere with the gentleman whom you recommended, for the reasons that the consideration I mentioned to you will dictate my looking for a new man in your part of the State."

\section{WilliaM PURCELL (DECliNiNg StaFF APPOINTMENT)}

" Office of the 'Daily Union and Advertiser,'

"Rochester, Dec. 10, 18\%'.

"MY DEAR Governor,-Your favor of the 8th was this morning received. It is hardly necessary for me to say 
that I thank you most sincerely for your very kind offer of a position on your staff with rank of Brigadier-General. But I feel eonstrained to decline for two principal reasons: 1st, I have no taste whatever, but rather an aversion, for military display, and could not persuade myself to appear in uniform on oceasion; and I never want to take my position without doing the full duty pertaining to it. 2d, if I were to aceept I might lay myself open to the suspicion or charge that while I had recommended a fellow-citizen for position without doing the full duty pertaining to it. $2 \mathrm{~d}$, If I were necessary to serve you that I should accept, the ease would be rlifferent, and I would be willing to yield my own preferences and meet the suggested thoughts of others. But I feel that by declining I enable you to give the place to some one of the many seckers after it, who have a taste for and will be glad to get it. I appreciate your reasons for declining to appoint the gentleman recommended by me, and if I were in your place I would have no one about mo tainted with IIoffmanism in any way.

$$
\begin{aligned}
& \text { "Your's, Se., } \\
& \text { "WM. Purcell." }
\end{aligned}
$$

\section{GOVERNOR TILDEN TO JOHN KELLY}

“Albany, Fcb'y 2S, 1875.

"Mr DEAR SrR,- Your note came this morning, and it finds me in a moment of comparative leisure which I have searcely had for weeks, so I avail myself of the indisposition to do anything more serious to reply.

"Yon need not be disgusted by the awkward accident about MeLaughlin, for, tho a little ridieulous, it is not serious; as I had all the elements of decision I aeted at once to avoid the competition which so attractive an office was sure to cause. You will, no doult, be surprised if I say that $I$ acted in this ease with no more celerity than $I$ have with three-quarters of the important appointments, and nearly all the small ones which I have had to deal with. For the grumble at my delays has no doubt reached you.

" $A$ small coterie of rogues, who, when they first recovered from the subluing effect of the election, started into a life of whispers, first eireulated the rumor that I had a softening of the brain; next, that I had suffered a stroke of paralysis; then, that I went to bed drunk every night; 
and at last came to the statement that I had lost my 'snap' - that I had not decision or energy to make proper removals or appointments, and, indeed, had become physically unable to make up my mind about anything.

"Well, under every mountain of lies there is usually a grain of sand of truth. In the interminable conferences with public bodies and committees and officers from Nov. 5 to Dec. 25 th, I did become very weary, and felt some exhaustion of nervous force and much indigestion. In the hurried preparation of the message I rested; and with all the burdens since, have recuperated, got arrear's nearly cleared off, appointments made, bills - some passed and others ready - and my physique well - nigh restored after six months of heavy strain.

"As to appointments, while the most have been despatehed rapidly as soon as reached, three classes have felt some delay.

"1st. Where there was no haste, and more important matters claimed the earlier attention. It is very likely I have not been altogether wise, as the world is largely made up of fools, in this respect. I am so formed constitutionally that I concentrate on what seems of first importance, and defer with almost contemptuous indifference what can as well or better wait.

"This is the habit which has given me success in business, in affairs, in the conduct of parties, in all things where military organizations and strategy require a concentration of all resources and efforts on the turning-point of the battle to break thro the opposing lines.

"But the hungry office-seeker sees only the narrow personal interest he pursues, and perhaps the appointing power should act consistently in respect to its general duties for the sake of dealing with fools according to their folly. Pcrhaps so.

"2nd. When things were to be worked out which could only be known to the appointing power. For instance, a gentleman sent me a memorandum from Arehbishop McCloskey suggesting two Catholic gentlemen for the Board of State Charities. He did not know that I had but three vacancies from N. Y., and that Mr. Tno. C. Deveraux, of Utica, would go out by expiration of his term if not reappointed. I sent to him to have his choice between the two he named, if only one of them could be taken, and to inform 
him about I)r. D. Te gladly preferred the latter to one of his own nominees. Mr. l)., you must know, is one of the best families of the interior, of the old and early Catholic aristocracy-a brother-in-law of Senator Kernan. IIow could I drop him?

"The one whom the archbishop preferred is the one who stands at the head of yomr list-IIenry Hognet. Then I wished to take one of the Hebrew persuasion if I could get a satisfactory one. I have good names, lunt location may compel me to forego this purpose.

"Then Mr. Howard Potter, who is one of the members resigning, making the vacancies I an to fill, has applied for an opportmity to see me hefore I make the appointment.

"These arrangenents take time, only known to me.

"The case delayed the most was that of judge in this district. There were applieants from commmities from all over the district. The appointment was marle in a few hours after the last hearing was given, which it would have been an offence to refuse. I have nore douht abont the delay in this ease than in any other, but the result is general satisfaction.

"3rd. But the real grumble is from those who ask for action which is doubtful or suspicions or which is cortainly wrong.

"Our fricud, Mr. Speaker MacGuire's grievance is this: There has been started the erection by the State of public buildings at fom places beside the capital of a most extravagant eharacter. One was the Ehmira Roformatory. This was taken out of the hands of a commissioner and put in elarege of an arehitect. Ilim I have the power to remove.

"Soon after. I came here my old acquaintance, Steve Arnot, loroke in half drumk, leating in the Speaker, Charles Walker, and Sonater Brarlluy.

"He insistcel that I should instantly turn ont the arehitect and put in a man maned by him.

"As there was no work going" on, and the ehauge might involve questions about contracts which hagl been brokennew ones pending, others to be made, and would involve the whole responsilility of wistom and fromality and honesty in the construetion-T thomglat the Governor had better not abdicate his fumetions, but lad better look carefully into the whole matter before he embarked himself and the party on the adventure. 
"The five buildings, including the eapital, are popularly estimated to cost 25 or 30 millions.

"I treated the matter very kindly, but deferred it. I shall continue to do that until I know enough about it to act wisely. If I change the manager it will not be for patronage (one $\$ 4000$ office of an expert), but to a man in whom I ean have a personal trust that he will not disgrace me.

"My information is that the Demoerats of Elmira and the eounty deprecate nothing so much as a return of the odium they have onee had to bear. I had no reason to suppose there was any special discontent until it appeared. The Speaker had informed me he had introduced a bill which would make all right.

"Since I have written so much more than I intended I will turn back and make it personal.

"Very truly, \&e.

"I have omitted to mention several narrow eseapes. The balance is still in favor of wariness, nothwithstanding some friends get tremors."

\section{JOIIN KELLY TO TILDEN}

“315 Lex. Avenue, New York, Feb. 2\%th, $18 \% 5$.

"Mr dear Governor,-I regret that your kind intentions were so fruitless of effect. I am pleased, however, to find that the intended appointment of MeLaughlin is generally approved. I am gratified, too, that Stemmler still is in the land of the living.

"I met your nephew, Mr. Pelton, at Marble's, as I presume he has so informed you, and there told him of Stemmler's death and advised a speedy appointment to fill the vacancy. My information was from the County Clerk's office; one of the principal clerks employed there gave me the information, and handed me at the same time the Daily News, which contained an account of the death of Stemmler. I enclose you herein a scrap cut from that paper, and one, too, referring to the matter afterwards.

" ' CITY NEWS.

“"Deatil of Judge Stemaler.-Judge Stemmler of the Fourth District Civil Court died this morning at his residence in Seventy-first Street. Mr. Stemmler has long been an invalid. A 
short time agro an abseess on his right side was operated upon, and he wats greatly benefited. Som afterward he began to fail and took to his bed. Deceased was 63 years of age'

\section{" CITY NeWS.}

"“The Mlax Who Will Fill Judge Stranallar's Place, Prorhoed the Latter Dh:s.-Mr. J. Fairfax MeLaughlin, who was yesterday appointed to fill the supposed vacancy in the jullgeship of the Seventh District Court, is a native of Maryland, where he practiced law for ten years before coming to New York, which he did about four years ago. IIe has practiced law in this eity, but is at present a elerk in the County Clerk's oflice. IIe has the reputation of being an elegant gentleman and scholar, speaking several languages. Judge Stemmler, however, is still alive.'

"I did not suppose that you would act promptly, and regret that the affair has ocenrred.

"Permit me to thank you for your well-disposed intention to do this kind faror.

"Wm. Dunham informs me that the bill anthorizing the Board of Supervisors, or rather empowering them to remuncrate him for the eare and maintenance of prisoners committed to the debtor's gaol is now in your hamls awaiting your signature.

"I have had some experience in the care of the gaol, and was paid a per capita for maintaining the prisoners. It's unjust, then, to Dunham that he should not be paid. It appears that the gaol has alway's been supported by the comnty, yet there was no law anthorizing it to be done. This was discovered when the predecessor of I)mbam sued for his money on Green having refused to pay hin. Dumban wonld not have taken the place if he had known that there was donbt abont the remuneration. This law, then, as you have evidently seen, simply allows the Board of Supervisors to pay him what is just and proper for services rendered, and for which he has not been paid by the enunty.

$$
\text { "Sour's truly, John Kinewy." }
$$

CHARLAS O'CONOR TO TILDEN

"Fon' Washixiton, leb. 25, 18\%i.

"Desu Gov.,-T have perused the substitute. As a matter of conrse my first thonght was that of a Yankee. I set to work guessing what comld he the motire of the change. 
"The substitute is so much more broadly comprehensive than I feared the 'toned-down' document would be that this conjecturing process led me into what, even to myself, seems a strange dance.

"The substitute proposed is very good, nay, it is as good and as perfect as the original, save in one single point. It covers every ground I ever had in view, save one.

"And, who beneath the sun, ean stand in the gap opposing that?

"Now let me explain to you my thoughts and mental processes.

"The swindlers have removed their property, $i$. c., the plunder, out of the State of New York. When the infamous decision was made in the State's own court that it, $i$. e., this State itself, had no title, that judicial point was theneeforth law in all foreign courts. If the State should bring an action in any foreign court, such court would be bound to decide against the plaintiff on the strength of that decree, substantially made by such plaintiff itself. But when the county or city or any like entity brought its action, the maintainability of that action would be a judicial question, determinable by the foreign judges according to their own views derived by them from the general principles of jurisprudence. These principles taught me, and should teach them, that as to most of these fraudulent abstractions the subordinate local entity had no title.

"When conferring with you concerning this subject prior to your message I distinctly stated this consideration.

"Though this may seem the product of a jurisprudent's recondite studies, it was born of practical common sense, and what is, perhaps, more to the point of my next observation, and to which it is preliminary, this idea is of a nature to be eminently popular. It might fairly be thought somewhat sensational.

"I was amazed to miss it from the lines of your message. If the thought that you could have any hesitation about pursuing the plunderers and their plunder to the ends of the earth presented itself to me at all-as I must suppose was not the case-it was, of course, instantly rejected as fanciful and silly.

"But now, after a long pause for thought, forth comes the substitute for your own original conception, so long and so faithfully nurtured and eherished by me. And what is 348 
the difference between the original and the substitute? Nothing whatever, exeept this one thing.

"The title to and ownership of the money or cause of action is to remain unchanged!! Since that title was Allenized it is not in the State.

"In all the courts of this State your substitute will be just as good as the original. For any future local framds I do not see but it is likely to answer every purpose. 'The single effect wrought by the alteration is that the stolen funds now in 'Belgimu or Brittany' will be safe for the enjorment of the thieves.

"To Dick Commolly it presents perfect immunity.

"Perhaps on this point you may say simply that I am mistaken; but such a remark never" convinees any one. 'The mistake may exist, but the child of error nerer ean see his mistake until some one takes the trouble of disseeting it and showing by adequate explanations that it is a mistake.

"I lave done as to this substitute. No further observations upon it seem needful.

"The Tweed spirit is rampant here. It is determined to possess itself of unrestrained power over all the offices as avennes to plunder. The local suits against 'Tweed et al. will no doubt be pushed; but if any judgments slatl be rendered which the gang shall dislike, their friends in the Refugium Peccatorum, as in duty bound, will reverse. Meantime the Statute of Limitations will do its kindly work. "Yours, se., "Cir. O’Conor."

\section{JOIIN BIGELOW TO TIIDEN}

“The Union League Club, New York, Tueslay, 1875.

"Mr De.ur Govin:ar,-I fully intended to drop in upon you to-day for an hour or two, hut found myselt this morning without a voice, and with a sore throat and headache. I wanted to say what I know it is muecessary to say, but might be cheering and strengthening to you, that in this struggle with Tweed's scattered forees, led by the Mayor, to recover possession of the city treasury, you will be sustained if you are, as I am sure you will he, firm and defiant. You have only to inspire the public with eonfidence that you eamot be sedueed or bullied into any conersions to the predatory class which is "trying it on' with you, and yon will find all 349 
of this city worth having are your friends. I am told that the Senate is likely to squelch the Costigan bill. If so, they will do wisely for thenselves, no donbt, but they will deprive you of an excellent opportunity in a veto message to give Wickham his coup de grace.

"There is nothing you ever did that went so to the heart of the New-Yorkers as the way you doubled up Tweed and his pals. This movement against Green is the secondary symptoms of the same disease, and offers you an opportunity of which, I take it for granted, you will avail yourself of strengthening the public confidence in your chieftainship.

"You do not need to be told that nothing would be so fatal to you as the friendship of the Ring who are trying to force you into their intrigues to plunder the city. Green's defence has produced a fine effect here, and while the war lasts his position will improve.

$$
\begin{aligned}
& \text { "Very truly Yours, } \\
& \text { "Joir Bigelow." }
\end{aligned}
$$

Mr. Green had not been long in the office of Comptroller, to which he was appointed for the purpose of rendering its records accessible to Mr. Tilden, before he had alienated pretty much every one who had business with his department. He doubtless supposed that that was the necessary result of doing his duty. But such was not the impression left upon the Governor's friends, and the following letter from Mr. Hewitt was not the first indication of a public sentiment which made his nomination for that office, at the expiration of Connolly's term, which he was serving, impossible.

\section{ABRAM S. IIEWITT TO GOVERNOR TILDEN}

"9 Lexington Avenue, New York, Feb. 23rd, 1875.

"Mr denr Governor,--You will be glad to learn that I am getting stronger, and the doctor recommends me to go to Washington for a few days.

"You may be sure that I have followed the Wickham controversy with great interest, and was delighted at the perfect ease with which you applied an extinguisher to his farthing candle. 
"If your brain keeps on softening for a few months longer, I think you will arrive at a development which will leave no doubt in the public nind as to your entire fitness for a much higher position than you now fill.

"Power told me yesterday that Kelly would be in Albany this week; let me urge that you have the firmkest of free talks with him. I am satisfied that he will meet your views on every point except the retention of Green. Now you camnot afford to let Green be slaughtered, but Green ean very well afford, in view of the momentons consequences to you involved in a disruption of the party machinery here, to solve the diffienlty by placing his resignation in your hands, to be used only when a suceessor satisfactory to you and to Kelly can he agreed upon. I lad a long talk with Green on Sunday night. He believes his position to be impreginable, and he is not at all conscions of the intense disgust with which he is regarded by the Tammany organization. He even thinks that the general committee might be got to indorse him. I told him very frankly that in my judgment it would be destruction to those who are really his friends to make any such issue in the committee, and I tell you that it is no use to try it. Your position and character will be with me the first consideration, and after that it seems to me that Kelly's position should be made as easy for lim as the eireumstances will admit. I think he understands Wickham now, and you and he ought never to be lacking in a perfect understanding witl each other. I have not seen Kelly, as I would have been glad to do, but you are at perfect liberty to show him this letter if you choose, as there is nothing in ny mind that I would not be willing to say to him personally on these topies, if he were to think it worth while to consult with me.

"Mr. Ruggeles has been to see me with regard to the Davis canal bill, which he thinks is a blunder; he is quite clear, and I agree with him, that the canal can only be properly administered by a general superintendent, nominated by the Governor, and approved by the Senate. The Governor should have the power to suspend or remove the general superintendent for cause. In this way the Governor will have the direct control of the eanal, and the eanal commissioners be relegated to their proper duties of anditing the expenditures, and seeing that the general superintendent does lis duty. 
"It seems to me that the position in which Davis has placed himself in regard to the Tammany delegation affords an unusually favorable opportunity for getting this legislation. It might be brought in as a counter-proposition to Daris's bill. If you had a proper understanding with Davis in advance, and he would agree to make not more than a nominal opposition to the substitute, the canals could thus be rescued from the corrupt ring which has plundered the revenues for so many years. If your administration could accomplish any such result it would be a great triumph, as well as a priceless benefaction to the people of this State.

$$
\text { "Faithfully yours, }
$$

"Feb’y 23, 1875 .

$$
\text { "Abram S. Hewitt. }
$$

"Hon. Samuel J. Tilden, "Albany, N. Y."

\section{CIIARLES O'CONOR TO TILDEN}

(ON THE GOVERNOR'S POWER OF REMOVAL FROM OFFICE)

"Fort IVashington, February 11, 1875.

"Denr Sir,-I wrote you yesterday. You will have probably seen, ere this can reach you, a partisan opinion in the Herald pronouneing your authority in the matter of removals limited to a Delphic response whether the 'reasons' or the 'causes' are sufficient. This, too, to be pronounced in the Mayor's specification of his reasons, without any anthority on your part to look out of it.

"This is unsound. Your power of approval is just like the Mayor's power of removal - absolutely diseretionary. You are not bound to pass upon the 'causes' assigned nor the 'reasons' communicated. The grammatical import of the law and the good sense of the thing show that your approval is to apply to the removal, $i$. e., the act itself.

"This joumalist's reasoning would tie you up very closely. If the Mayor were to remove Comptroller on the ground that he had shown himself quite unworthy of confidence by kicking his wife in a church on Sunday, in the face of the whole congregation during divine service, the only point before you would be whether such a cause-assuming the fact to be as asserted-was in point of law sufficient ground of removal. Thongh Green had no wife, was sick in bed at home on the designated Sunday, and that, owing 
to bad weather or some accilental eause, there was no service in his church on that day, you must approve his removal and let him be kicked ont nuless vom wore prepared to say that, in point of law and reason, such misconduct was not objectionable in a public oflicer:

"The truth is, the Denuocratic branch of the 'Tweed Ring is no better than the Republiean branch of the sane. The former and the latter have the same aims. Eithor from weakness or something else, the Mayor goes with 'our friends.'

"Yon must make up your mind to go with that interesting party or to go against it. I am against it; notling will persuade me to withlold any little power I possess from the anti-swindlerism party.

"II is Excellency, Samuel.J. Tilden,

$$
\text { "Yours truly, } " \text { Cir. O'Conor. }
$$

$$
\text { "Albany, N. Y." }
$$

\section{FlANCIS C. BARLOW TO TILDEN}

\section{"Personal.}

“New York, 21 Park Row, Feb. Sth, '7j.

"IIon. Sami. J. Thlonen, Governor, de.

"My neal SIR,-I am satisfied that the choice of Corporation Comsel, in place of $\mathrm{Mr}$. F. Delafield Smith, lies between Mr. E. R. Robinson and Mr. Wne. C. Whitney. There is no doubt about this.

"I am, furthermore, pretty sure that $\mathrm{M} r$. Wickham would be glad of an influential pressure which would comterbalanee the pressure of Wm. ('. Barrett, Thos. Boise, and others in favor of Whitney, and authorize him (the Mayor) to appoint Robinson.

"You know what the influences of Parrett et al. are, and I an sure you would not think them desimable advisers of a corporation counsel, as they certainly would be of Whituey.

"I write to beg you to help, if you can, Rolinson. I an sure lie is falr more in aceord with Mr. O'conor, l'eckhan, ete, than Whitney would be, thomgh, of entrse, I am only able to speak for myself.

"I hope carnestly that you will be able to furtluer the eause of public justice, for which you have done so much, 353 


\section{ETTERS AND MENORIALS OF SAMUEL J. TILUEN}

by bringing about, so far as the matter comes before you, the appointment of Rolinson.

"Yours Very Respectfully,

"Francis C. Barlow."

\section{SAMUEL HAND TO TILDEN}

"State of New York, Executive Cilamber, Albany,

"Monday Morning.

"Gov. Tilden.

"Mr Denk Governor,-I had intended to see you before or when I delivered the enelosed and satisfy you of my reasons.

"But the storm yesterday prevented, and I do not find you here this morning, and must go down. Fearing you may want to act at once, I leave it.

"I will see you and justify soon as possible. "Yours with respect,

"Saml. Hand."

\section{SAMUEL IIAND TO TILDEN}

"Albany, Jany. 30th, 1875.

"His Exchillency, Governor Tilden.

"Mr DEAR Sin, - When I received your note to-day by Mr. Pelton I had already spoken to my partners of the suggestion you had made to me yesterday that you might, in certain contingencies, ask me to accept the appointment of judge, and of my promise to you to consider the subject.

"After talking with them, and upon careful consideration, I have coneluded that at this time it would hardly be possible for me to mudertake the duties of the office of judge of the Supreme Court.

"In thus declining your very complimentary offer', I am and shall always remain decply grateful to you personally for the kindness of your intentions towards me.

"I assure you that my present action is not from lack of due appreciation of the dignity and importance of the office, and of the high honor, especially coming from your hands, it would confer upon me.

"Yours, with the sincerest regard and respect, "Saidel Hand." 


\section{CILARLES O'CONOR TO TILDEN \\ " Font Washesgtos, Jany. 7, 1875.}

"Mr dear Sin,-Perhaps I am too suspicious or too prone to evil constructions, but I camnot resist the belief that there is a complete conspiracy. And for aught I see, it may suceeed.

" $\Lambda$ t the ontset, Curtis and Porter were ealled in and gavo a written arowal of their doubts whether there was any remedy. When the reform Mayor, a Republican, was eoming in, Snith was substituted for O'Gorman. Now recently, eounting in some way on favor or folly or softness in Vickham, Smith arranged it to dismiss Pecklanm and Barlow and substitute Porter and Curtis!! All the seamps have fled except Tweed. Field is hmrying up Tweed's criminal case, and the moment he gets a reversal, which is pretty sure, Tweed will fly. No civil process of arrest being out against him, this is casy.

"What are we to do?

$$
\begin{aligned}
& \text { "Yrs., de., } \\
& \text { "Cir. O’Conor." }
\end{aligned}
$$

\section{A. LOOMIS TO TILDEN}

\section{"Little Falls, Jany. 6, $18 \% .5$.}

"Dear Sir,-The usurpation by the military arms of the United States of the entire gorermment of the late State of Lonisiana has been consmmmated by the forcible expmlsion of members of the Legishatme from their seats by United States soldiers.

"This oceurrence demands, in my judgment, an expression of public opinion in relation to it more efficient than editorial denunciations, however emplatie. 'The press exerts a wonderful influenee, but there are exigencies in which its efforts to arrest abuses may be greatly strengthened by publie opinion expressed in more anthentic form.

"In Touisiana the executive branch has for somo time past been kept in place only by soldiers under the orders of the Commander-in-Chief of the United States armies. The judges hold their offices by favor of the same Presidential commander. Now he hats tiken possession of the only remaining branch of the State govermucnt, the Lecrislature, by direet military foree. The usurpation is complete. The 
State govermment is extinct. One State in the Union has ceased to be. The atroeions despateh of General Sheridan, commander at New Orleans, to the Secretary of War, illustrates the arbitrary spirit and thirst for unlimited martial power that inspires the orders under which he holds the State in subjection, and exlibits in true colors himself a willing and dangerous instrument of ambitious aspirations.

"Under this crisis I beg respectfully to suggest for your consideration whether some official demonstration ought not to be made by the government of this State-an expression of strong reprehension and warning-in the hope that it may aid in recalling to their proper duties those who are now lending their official influence to the overthrow of our republican institutions. A special message by you to the Legislature and a prompt and energetic protest by the Assembly, and I should hope by the Senate also, may be a timely measure of far-reaching benefit. It seems to me that something of this nature is demanded by the exigeney, and would be an act worthy of the ehief magistrate of the State of New York.

$$
\begin{aligned}
& \text { "Very Respectfully, } \\
& \text { "Yours, \&e., "A. Loomis." }
\end{aligned}
$$

\section{PECKILAM TO TILDEN}

"Personal.

" 18 Walr Street, New York, Jan. 2, 1875.

"Mr DEar Sir,--In speaking of the Albany judgeship, or rather that of the $3 d$ distriet, you always said that you would consider it after the first of Jan.

"I left with you at your house some papers on the subjeet, including the petition of almost the entire Albany bar and letters from many persons and our firm myself.

"I have nothing to call me to Albany now, and I am very busy here, but if there exist any conditions as to which I could properly say anything, or as to which I might present facts or suggestions with respect to this appointment, I know I may rely on you to advise me thereof and to give me a hearing.

"There is nothing in which I take so deep an interestnothing, I mean, of a personal character-and you can exeuse any apparent over-persistence. I am not much given 
to explessing enotions, hut all I have are concentrated in this.

"E. I). Smith has 'dicentimued' retainers of Genl. Barlow and myself, and, I suppose, of Mr. Carter. He says it is pursuant to his correspondence with Vanse.

"As the local proscentions stand now, the defts. might as well appoint the eounsel to proseente.

"Unless some one has charge of them very different from Smith and his friends, the prosecutions might as well be abandoned.

$$
\begin{aligned}
& \text { "Yours truly, } \\
& \text { "Wheeler II. Peckinam." }
\end{aligned}
$$

\section{HORATIO SEYMOUR TO TILDEN}

“Utica, January 1, $18 \% 5$.

"Mr pear Sir,-I do not think I shall be alle to see you lefore you send in your message. Upon one point I am anxions - that is the canal question. The constitutional amendment, the state of the country, and the condition of commerce makes this the leading question of the day. It has, since yon dealt with it, taken new forms and aspects. There are some facts which may not be known to you. This subject cannot be treated by you in your anmul message in a clear, full way. It needs a message for itself. If you will simply give the return of last year's business, and then, withont indicating any policy upon any poinl, say you will send in a special communication with regard to it, you will be able at your own time to treat the subject in a way which [will] interest the whole comtry. You ean neither do yourself nor the eanals justice by speaking abont them without making a long message, which must be aroided. There will be another advantage in this. You will have a rod over those whose purposes and plans are yet to be diselosed. I have my fixed and sottled opinion about the eanals to which I am publiely committed, and I do not like to clash with your's, ete.

"Mly health is not good, and I do not know when I ean go away from home.

$$
\text { "I am truly yours, \&e., }
$$




\section{CHARLES O'CONOR TO TILDEN}

"Font Washington, February 10, 1875.

"Mr dear Gov. Tilden,-Your favor of the 8 th is this instant received. I have never met the Mayor but once. I then diseovered that his prime object seemed to be the removal of Green. This is the prime object of all the swindlers, whatever political hanner they sail under. Our friend Marble is also hostile to him. They are determined to get him out.

"I drew the impeachment of the counsel. As drawn it contained what more prudent men than myself might pronounce an injudicious paragraph against the appeals majority. In a council, consisting of Marble, Burton N. Harrison, and perhaps others, this was strieken out, and perhaps rightly. The keystone to the arch imparting favor to Tweed was the story of the substitution of Curtis and Porter for Barlow and Peckham. But I had to acquiesce in omitting that. The letters on this subject are in the New York paper's about 30th and 31st December.

"The Mayor sent to Barlow, Peckham, and myself for our suggestions on the council's answer. Peckham's and mine contain all that is needful on this subject. Mine, unwisely, you will say, opens fire on the judicial majority, and states with suitable words of characterization the Porter and Curtis substitution. This you will probably not disapprove.

"To mnderstand this branch of the case precisely you shonld know a few facts. I had all my life greatly aided and befriended this man. But this was not strange; I always aid the needy and never strike any one willingly. He thought me very amiable, but took good care to keep out of my way from the moment he took offiee until he was accused. Then he could scarcely believe his senses; so, near midnight, he visited me, cried, implored, etc., etc. I gave him no hope, and to his face condemned him, observing courtesy to be sure in the choice of words. I commented in terms as apt as this duty would permit, on his Porter and Curtis affair. This will serve to account for his subsequent attempt to reinstate Barlow and Peckham. No more need be stated. I have requested Peckham to send you a copy of his reply to Smith; a copy of mine will reach you as soon as it can be made. 
"I an quite sure the power that is bent on removing Green will not improve the Corporation Comsel's oftice; consequently, I cannot desire that the Mayor should be free to fill it.

"I suppose you know that the only political sentiment in which I indulge is hostility of official thieves. This, like my hostility to the negro war, places me almost alone. Some degree of eireumspection in my movement is therefore necessary; and, perhaps, some little cantion on the part of political men low far they permit themselves to be seen in my company, or to be suspected of being influenced by me, is desirable to them.

"Ilence I doubt the expediency for cither of us of my putting up at the Governor's mansion for a day or two.

"I may say very little, and will probably do very little to testify my dissent; but I will see better reasons than have yet been exhibited before I will in any way assent to Judge Allen's standing as the law of the land.

"Were I Governor I would not assent to Sunith's removal without an assurance as to the suecessor. But this, of course, should have no influenee with you; for, as far as you have indieated a choice to me, you have not named any .one who would impart to that office the needed vigor. $\Lambda$ t least such is my belief.

"I am morally certain that the majority in the "lyblid body' will on some impalpable technicality defeat any civil suit that can now be bronght against the Ring. Nothing but the clearing up bill now in your hands will draw their teeth."

\section{MALCOLMI CAMPBELL ${ }^{*}$ TO TILDEN}

\section{"Confidential.}

“New YоRк, March 2d, 1875.

"MY wenk Governol,-The enclosed will show you how I employ a leisure hour. Although I have not been editor of Franli Lestie's since I left it after the campaign of '72 I occasionally write for it, and my articles are always published. My feelings towards you have already been shown in the columns of that paper, and anything $I$ ean do in the future will be most cheerfully done.

\footnotetext{
* Son of Judge Camplell, once a surrogate of New York, and, like his father, a Democrat.
} 
"I hope and expect to see you our nominee for President next year; and therefore, assmining the privilege of old friendship, I give you my views on a few points, even at the risk of appearing to offer masked-for, and perhaps unwelcome, advice. It was said, and I think truly, that a President, when in office, knew less of the true state of public opinion than any ordinary observer. Perhaps the rule may hold good in a modified degree as to a Governor. If so, I trust you may be an exception.

"I believe I reflect the opinion of a large portion of our citizens at the present moment when I say that Mayor Wickham is thought to be drifting in the direction of "personal government,' with a very strong leaning, in the distribution of the most important places, towards his former associates in Apollo Hall. The gentleman said to have been fixed upon by him for Corporation Counsel, Mr. Whitney, is entirely unknown either by the bar or the general public, except by the fact that he ran for District Attorney on the Jimmy O'Brien ticket. His appointment would give satisfaction to no one but those immediately benefited by it, while the selection of O'Conor (if he would accept it), or Peckham, or, indeed, any well-known lawyer, would give assurance to the public that the promises of reformed Tammany really meant something.

"It is probably apparent to you that a dead set is being made for the scalp of our old friend Green. He is undoubtedly the most unpopular man in the city, and such a movement would be too popular for any one but a man of nerve to resist. As his name has been so intimately connected with your own, your position, in ease this issue is presented, would be at least embarrassing, and the result, in any event, would be to your prejudice in subjecting your action to criticism. It seems to me that all this might be avoided by getting Green to resign, not as a forced measure, but as a voluntary act, and with flying colors; and he might resume his old place on the parks, or receive some other position better suited to his tastes and temperament than the thankless office of Comptroller. I say this without a particle of hostility to Mr. Green, for whose ability I have a great respect, and in whose honesty I have unbounded confidence. I have no personal ends to subserve, and my suggestions spring from a sincere desire to avoid in an honorable way the possibility of persons who are not at heart friendly to 360 
you forcing upon you an issue which might injure you with the public. If you were to approve his removal, instead of being regarded as a second Brutus, you would be aceused of yiclding to the pressule of those who had designs upon the treasury; if you declined it would be attributed to personal friendship against the manimous voice of your party in this city.

$\therefore$ I trust that my remarks may not be considered intrusive. If they are too frank, it is the fanlt of my nature and of my carnest wish for your continued popularity in your present station and for your advancement to a higher one.

"I remain very faithfully and truly yours, "Malcolm Chimpell."

\section{JOIIN BIGELOW TO S. J. TILDEN}

"Westmoneland Hotel, March 21, 1875.

"Mr dear Tilden,-You conld not desire anything more cordial than the reception given your message here. The press you see. The people are equally manimous, and I think enthusiastic. Part of this enthusiasm springs from the expectation that you will make as thorough work of the canal ring as you did of its elder brother in N. Y. Be sure you do not disappoint these expectations. I have not heard much lately about the softening of yr. brain, but there are some inquiries for the kind of tipple you are partial to. The Tilden brand is just now rather the favorite.

"I dined with Bristow at Stonghton's last night. I am told he had third term on the brain very bad. Edwards Pierpont is talking up Bristow himself tor the next Rep. candilate. This is P.'s way, I suppose, of hesitating his dislike for Grant.

"Wickham's political estate is already pretty much bankrupt. You will soon be able to buy it all in for a bagatelle. What a lucky dog you are to have your enemies here and in Alhany ofticered by two such blunderheads as Wickhan and MacGuire. They relieve you from a great deal of responsibility, and serve the important purpose of seapegoats to earry the sins of your party into the wilderness.

"Please give my compliments and regards to Mrs. Pelton. "Very truly Yours,

John Bigelow.

"Judge Comstock likes rr. message, but thinks it not 301 
ealculated to promote your political fortunes. That is not the first error in judgment he has made."

\section{ALGERNON S. SULLIVAN TO TILDEN}

"Hon. S. J. Tilden.

" 29 IVALL STREET,

"New Yorк, March 22d, 1875.

"Mr dear Sir,-Among our best people there is but one opinion as to your message about the canals.

"You are right; the case is urgent, the evils you point ont are of the greatest importance, both in their finaneial and moral aspeet; the remedies proposed seem practical, and the honor of your administration, of our party, and of all good citizens is involved in your movement.

"Be firm and active, and if you feel that your success would be faeilitated by" a public expression of opinion from our strong men, we will organize such a demonstration.

"Very Truly Yours, "Algernon S. Sullivan."

DAVID DOWS TO CHAS. STEBBINS, PRITATE SECRETARY OF GOVERNOR TILDEN

$$
\begin{aligned}
& \text { " } 55 \text { West 23Rd St., New YoRK, } \\
& \text { "Evening, Mch. 22, } 1875 .
\end{aligned}
$$

"Mr DenR Sir,-I wish you would send me by mail one or two of the Gov's message of the 19th inst. I want to keep one for future ref'ce. I notice it was to be printed.

"The truth is, Gor. Tilden understands and fully appreeiates the canal question better than any Gov. we have had for many, many years, and altho' this last message throws a bombshell into the Canal Ring camp, still the Gov. will be backed up by the people, who do and will approve his course. We are all well.

$$
\text { "Yours, }
$$

"P. S.-Tust as I had written you, Mr. Pelton called, with your letter, and I had a pleasant talk with him. I told him I had just written you and him, and asked you to send me the message; so he, Mr. P., gave me one.

"Mr. P. has promised to call again when in eity, and I hope he will. 
"You can depend upon all the strength and support, both physical and moral, that 1 have got to back up such sound and practical views as Gov. Tilden puts forth in his two papers.

Yrs. Sincerely,

"David Dows.

"P. S.-I wish you would send me a few of the printed messages."

\section{WILLIAM CAMPRELA, TO TILDEN}

"Cinerix Vallex, March 23, '75.

"Denr Governor,- $\Lambda$ s a taxpayer I return my thanks for your canal message.

"Many years ago that sagacions politician, the late John D. Irammond, author of the Political IIistory of New York, remarked that whaterer political parties there might be in New York there always would be 'an Eric Canal party.'

"And he was right. There always has been a canal party. The Constitution of 1846 manacled the State. It declared the eanals should never be sold. The spoils would be gone. The last constitutional convention determined also to keep the manacles on. The Legislature had provided that of the members of that convention thirty-two should be named whose election should be secured, and this, too, without reference to location. Sixteen were named by the Republican party and sixteen were named by the Democratic party.

"Of this thirty-two, not one whose residence was sonth of the Moliawk and west of the Mudson was named by either party. There was one north of the Mohawk. With that exception, commencing at New York and following up to Albany and Troy, and thenee on the Erie Canal to Buffalo, we find the location of them all, except one or two on the lateral canals in the western parts of the State. There has not been a high offieer of the State in the same region for, I think, the last quarter of a century.

"Surely, my dear Governor, there must still be a eanal party. Bnt I see you are resolved that the stealing shall cease. I was in the Legislature of 1869 with your brother, and on a celebrated oceasion witnessed his stern integrity. I recollect well putting my hand on his shoulder and remarking-

" Alone among the faithless,

Faithful only he.' 


\section{LETTERS AND MEMORIALS OF SAIIUEL J. TILDEN}

I said then the blood of old Dr. Younglove told. I am rejoiced to see that it has told again.

"Very Respectfully, your old friend, " William W. Campbell."

\section{G. W. CLINTON TO TILDEN}

“ Buffalo, March 23, 1875.

"Mr deAR Sir,- Your canal message is heroic. It commands my respect, and must attract to your support all honest eitizens. If I were sure that the prevalent notion that your high and honorable course will involve you in war be true, I should be delighted to plunge into the battle, with a God save the right! I cannot now conceive a more honorable ending of the humble career of

"Yours very respectfully and truly, "G. W. Clinton."

\section{W. W. NILES TO TILDEN}

" 8 Wall Street, N. Y., Harch 25th, 1875.

"Mr dear Friend,-Ralph Waldo Emerson says: "When a man is in pursuit of the absolute truth every spear of grass is with him.' And an old book that is sometimes seen in families down this way (and which, if by ehanee there is a copy near the capitol, I eommend to your respectful eonsideration) says, 'The stars in their courses fought against Sisera' because he was wrong.

"I am impelled to write thus much beeause I see your great opportunity and your great danger in the matter of the Canal Ring.

"I have no fear of their fight against you, for then you would be on your mettle and on your guard; but I fear and write to warn you against their conditional surrender.

"If they come into your camp on any other terms than ' uneonditional surrender' you will be subjected to the danger of treachery and to that other condition that brought poor, honest Tray to grief.

"Make your fight as Andy Jackson used to for unconditional conquest or hopeless defeat, and you are all right.

"I hear much talk, and what I fear is less constrained and politic than what is spoken for your ears. 
"I hope you saw the Albany letter of the Sun of to-day, and also the Tribune editorial; they are encomaging.

"Hurrah for young IFickory forever!

"Yours 'Truly and forever, "IV. W. Niles."

\section{PETER COOPER TO TILDEN}

"New Yors, March 25th, 1875.

"Mr DEar Sin,- - T have seen, in common with others of your fellow-eitizens, the published accomnt of your statements and messages in reference to the management of those intrusted with a great and valuable interest of the peoplethe canals of omr State.

"Having for a long time, in fact, from the beginning of that industrial enterprise, taken a deep concern in the prosperity and improvement of the canals of New York, and having, in common with many others interested in them, been much disappointed in the vast expense that has attended the keeping of this great highway of commerce in repair, allow me, my dear sir, to congratulate and thank you for the eflicient and courageons method you have taken to investigate what abuses may have existed in times past, and to put this great industrial and commercial interest into a nore farorable if not a more honest administration.

"I impeach no one personally. It will be your provinee to investigate the facts and personal bearings of such eharges as you have put forth in your excellent message in regard to the administration of the canals. But the results are obvious to every intelligent citizen, and lead to the natural inference that the large sums appropriated, and the legislation hitherto employed by the people of this State, to guard, improve, and administer economically this great public enterprise, have been intrusted to parties either ignorant $n$ irresponsible as to their duties in this matter.

"This is the present feeling of the people. And I only express a general desire that the investigation you reconmend shall be conducted at once by a committee of intelligent and honest men; that this investigation may lead to the truth is the fervent desire of all good citizens. With renewed expressions of thanks, and with great esteem, "I remain, Yours with Great Respect, "Peter Cooper." 
"To the Hon. Samuer Timpen.

"(Mar. 18, 18\%5.)

"Dear Sir, -By referring to the records you will find half million of the city's property given by William M. Tweed and now held by one Mrs. L. G. McMullen.

\section{"A Friend to Justice and a Taxpayer."}

\section{CHARLES O'CONOR TO TILDEN}

"Fort Washington, March 27th, 1875.

"MY DEAR Gov.,-If 'honor's voice' has any charms for your eye and ear you ought to be satisfied, for it silences completely all other sounds. Even the swindlers themselves dare not condemn.

"Peckham was not come-at-able 'til to-day, and I could not get away from occupations here. We are to meet and set things agoing on Monday.

"My present motive in writing is to speak of public employments, but I beg you distinetly to understand that I am not a solicitor. That I am determined never to be. I only write to give you information, or more properly, to awaken your attention. I liave no personal favor to gratify or personal desires to accomplish in this line.

"The committee of 4 is of course designed to make an equal division. Still, you have the initiative and possibly may have through that circumstance a valuable facility. You will have to name two Republicans. If possible you ought to name Barlow as one of them. I need say no more than give the hint and let you know that he will act. You know perfectly well that he has an ardent desire to unearth the canal thieves, and you seldom meet with one of any party so pertinacious and of such unflinching resolution.

"If you want a scholar, with great capacity to write for the public, do not overlook Wm. B. Reed, of 34 West 27 th Street. I know no man who could serve better in that way. And he has very recently and very suddenly been cut off from the Herald corps. If Bennett was here or could be addressed on the subject this would not have happened.

"I can only attribute it to the zeal of some in his cabinet against Green.

Yours truly, "CH. O'Conor." 


\section{LETTERS AND MEMORIALS OF SAMUEL J. THLDEN}

\section{IIENRY L. FISII TO TILDEN}

" Office of the lochester Transportation Co.

" Rochester, N. Y., March 27, 1875.

"Mr dear Sir,-The Committee of the Whole adopted a resolution and recommending to the House its passage, inpowering you to appoint a commission to make the inrestigations. Of this you, of course, are aware. Subsequently a resolution was adopted directing the judiciary committee to prepare a bill for the same object. Now, what I wish to say is this: the friends of this move of both partics in both IIouses shonld be put upon their guard to see that it is what is required. You must have the very fullest power and authority. I found many warm friends of yours in both parties in both Houses; but everything hangs on your getting proper authority, and your friends must certainly be most active and vigilant and now. The authority must be full and broad. Each friend in both Houses onght to be fully posted as to how to act and what to do. The leaders in each House should be advised and most thoroughly posted on all points. Coneert of action is inperative.

"The shaping and passing of the bill is of the very highest moment.

"It should be carefully serutinized and drawn before its introduction, and watehed with the greatest assiduity and ficlelity.

"You are fighting the whole 'Prussian army'-officer's, rank, and file.

"You must sueeed. You must be backed; there should be now no such thing as failure.

"I dare not think of the eonsequences that would follow a failure. You are grappling with subtlety, ingenuity, adepts, experts, dangerous, and most unserupulous men whose lifo has been spent in plundering the people, and who are most expert in controlling and handling men.

"Sce to it that the Secretary of State don't flood the State with ring census tokens. This will be a heavy blow to you and the cause if he does. I make these suggestions, fearing you might, in the exeitement and pressure of the business of yr. oftice, overlook these matters, and perhaps might trust too much to $\mathrm{yr}$. friends. Church is with the Ring in all their deviltry.

"Upon the proper start - the proper authority of the 
Legislature - hangs great events. If I can do anything, command.

\author{
"Hastily and as ever", \\ " Truly Yours, \\ "Henry L. Fish."
}

\title{
JOHN KELLY TO TILDEN
}

\section{"Personal.}

“New York, March 30th, 1875.

"MY DEAR Govr., - I telegraphed you yesterday requesting that you would take no steps to fill the vacancy of the 7th district until you hear from me. You may consider this presumptive, and if you do I shall not complain, or take exception thereto.

"I shall never forget the promptness with which you responded to my appeal in behalf of Mr. McLaughlin, and I am afraid that my anxiety in his behalf has subjected you to humorous criticism from your enemies and an antipartisan press. I am, however, consoled by the fact that you would have been more than pleased with the man. His abilities are eminently superior to any person who fills these places at present. As an evidence of his talent I refer you to his description of yourself, ex-Governor, and myself at an interview which took place at your house last January. I did not even know that he intended to write anything, and was not aware of it until I saw it in Marlborough paper, M., etc. Now you will ask yourself what can be the motive. I will answer by telling you none at all, except this that I am a lover of talent; but I assure you that this gift would hardly influence me unless it was coupled with inflexible integrity. He has both characteristics. Having said this much relative to the man, I shall now speak of my impression as to what has occurred in relation to McLaughlin's intended appointment and what ought to be done to place him and yourself right before an observing and critical public.

"You appointed him, and when you did so there was no vacancy. Your motive was of the best kind. You relied entirely for your own justification on that which I represented to you. Would it not be well to appoint him again? This will enable him to appear well before the public, and at the same time vindicate yourself and show 368 
the people well-established consisteney in what you originally intended for the public good. If you think well of this idea-

"Then let me suggest to you another. Me will not accept the place, and for the reason that he could not do so. The County Clerk is an invalid, and is now in Florida seeking health. His deputy lats been recently appointed to the position of 'Dept. Commissioner of Public Works.' MeLaughlin has been promoted to G.'s vacancy, and could not in honor except [sic] any position while his superior is abroad siek. 'The place of civil justice would be pecuniarily' a godsend; his moral ol,ligations wonld prevent him from cxcepting [sic] the place. Thongh, as I said before, it is due to him that the place should be offered him in justification of you both. This would soften the asperities of the envious and silence the press, which is prone to contemptuous ridieule. When he shall have resigned the position.

"Haring said this much in faror of McLaughlin, I shall now give you my opinion as to who should receive the appointment. After mature consideration I have convineed myself that it is due to Alfred T. Ackert, of your own district. He is lonest, and possesses talent enough to make him a competent judge. The objection that would be offered that he is not a resident of the district ought not to have any consideration with you, and for the reason that if the bill passes the Legislature to eleet the civil justices on a general ticket, as I think it will, the local politicians will not have anything to say except in a general way; and if they did object it would be but temporary.

"I hope you will consider Ackert in relation to that appointment. Tle has worked hard for three years in our organization, and his duties have been exceedingly laborions, and yet he has never complained, but willingly performed them with alacrity.

"I have just received Mr. Pelton's letter, in which he refers to the receipt of my despatch relative to Col. Vilner. This must be a mistake. I did not send a despatel in behalf of the above-named gentlemin, and if he received one it is a forgery. I sent one in the Stenmler's case, and no other one. There is no dould of this gentleman's demise now. Perhaps you have not been aware of it. IIe died on last Sunday evening.

"Your message on the eanals has raised you very high 369 
in the estimation of the men of all parties. The wonder is now that none previous to you had the courage to meet the men who instigated these frauds and to show them to public condemnation. Your predecessors were as well informed of their existence as you; but for some reason of their own, not very difficult to fathom, neglected their duty. These exposures will have a salutary effect, and will be the means of eorrecting abuses which should have long since been eradicated.

"Pursue the good work you have commenced, no matter where the rod will fall, either on friend or foe. It is about time that politicians should understand that they cannot pursue their nefarious frauds under the supposition that no harm can fall upon them on account of their political adhesion to party.

"You should take some steps on the papers before you in the ease of Smith. You may depend that unless you do there will be a general attack made on you by the papers of the eity. It is already being whispered that your recent message was coneocted to divert attention from matters conneeted with this eity. Smith has not been idle in cireulating the story that you are his friend and will not remove him, notwithstanding the onslaught which you helped to prepare against him at the beginning of the year. You have already had these papers too long without taking action. I beg of you to aet immediately in this case. If you are not fully convineed in the fire commissioner's case, you can wait until you have had further time, and yet I am fully satisfied that you have had time enough to determine the course you ought to pursue.

"Yours very truly, . "JoHN KELLY.

"His Excelleney S. J. Tilden, "Albany, N. Y."

RESOLUTIONS IN RESPECT TO THE CANALS OF NEW YORK

"New York CinAmber of Commerce.

"At a meeting of the Chamber of Commeree, held Thursday, April 1st, 1875, Hon. William E. Dodge, president, in the chair, the following resolutions offered by Hon. George Opdyke were unanimously adopted:

"Resolved, That Governor Tilden, true to his honorable 370 
record agilinst the fraudulent Ring officials of this city, has now placed the eitizens of our whole State under lasting obligations by his bold and nusterly exposure of the enormous fromds comected with the administration of the New York canals.

"Resolved, That this Chamber, as the oldest eommereial organization of the State and the one expressly anthorized by eharter to speak in the name of the entire commereial interests, feels specially called upon to express its gratitude to the Governor for his fearless and vigorons effort to arrest the frauds, so discreditable to the character of our State and so injurions to its commercial interests.

"His effort deserves the commendation and hearty support of every citizen of the State.

"Resolved, That this special message of the Governor on 'canal frauds' is in perfect harmony with the views he expressed in his annual message. In that doement he manifested broad and accurate knowledge in relation to the present condition of the canals, clearly pointed out their defects, and suggested the remedies that he deemed essential to their increased efficiency and productiveness; and also to the integrity and economy of their administration. Among the remedies he suggests are a proper disposition of the umproductive lateral canals, the securing a uniform depth of seven feet in the waterway of the Erie Canal, and modifications in the present plan of administering them.

"Resolved, 'That, in the the judgment of the Chamber, it is absolutely essential to the eflicient nanagement of these canals that this department of the State govermment shonld be under the control of a single executive head, appointed by the Governor and Senate, and removable at the pleasure of the Governor, with power to appoint and remove his subordinates, and who alone should he held responsible for the proper management of the canals. All experience goes to prove that this is the only safe method of securing effieieney, fidelity, and ceonomy in the administration of public affairs.

"Resolved, That this Chamber will wateh with deep interest the progress of this praisewortlyy effort of the Governor to secure perfect integrity in the Canal Department, and will aid that effort by all proper means within its power.

"Resolved, That a copy of these resolutions, dnly anthenticated by the officers of the Chamber, be forwarded to his Excellency, Governor Tilden." 


\section{G. HILTON SCliBNER ${ }^{*}$ TO TILDEN}

"Green Core Springs, Florida, April 2, $18 \% 5$.

"To His Excellencr, Simule J. Tilden.

"MY DEAR Sir,-By the scanty and irregular news we receive from New York at this distant point I learn with a degree of satisfaction which I cannot fully express that you are making a determined effort to correct the abuses in the canal management of our State.

"Speaking with the earnestness inspired by my experience as a member of the Canal Board, I trust that you and your friends in this undertaking will not be dissuaded from the views you have taken and the course you have marked out by any political or personal influence whatever.

"I do not fear that you will. Let no 'hue and cry" about 'corporations and monopolies,' or the importance of general laws under the constitutional amendments, divert attention from this subject. Everything now before the Legislature or demanding your attention should, in my judgment, be subordinated to this matter if by so doing these irregularities in canal management may be eradicated, root and branch. I have studied your analysis of the subject, and I believe you are on the right track.

"Which political party shall suffer most, or who shall go up or who down, are matters of minor importance if only right and justice be done. Pardon the frankness and emphasis with which I address ron, but while I conld never quite grasp the evidence, I often felt, as a member of the Canal Board, and now feel morally certain, that the field you have entered is fruitful in long-standing and frightful abuses. Accept my best wishes for your snccess, and trusting you may receive, as you certainly deserve, the sympathy and co-operation of all good men in this great undertaking, "I remain as ever, "Most truly yours,

\section{"G. H. Scribner."}

On a visiting-card:

"Personal.

"MY dear Gorr.,-You are at liberty to use the accompanying note in any way you may deem proper for the good of the cause." 
"New York, 18 Wall St., Apl. 6, $18 \% 5$.

"Mon. Saml. J. Tilden.

"Dear Sn,-I have your telegram. Mrr. O'Conor was to have been here this morning. I gave him the complt. in the suit vs. Sweeny and Smith last Friday. He sent word on Saturday that the presence of Ingersoll was a condition precedent to his going on-i. $c$., that he needed to see him before making application for an attachment, ete.

"So you see that it is impossible to attach until Ingersoll arrives. This morning, instead of eoming in, as he had yesterday written me he would, he sent me word that he was suddenly called elsewhere and that he would be in tomorrow morning.

"The Tweed papers were all ready, but I had not intended to issue them until to-morrow-i. e., after again seeing Mr. O'Conor'; but on receipt of your telegram I concluded to commence that action, and so issued processes, order of arrest, bail $\$ 3,000,000$, and attachment $\$ 6,000,000$.

" Will have lis pendens filed forthwith here and in Westchester.

"We find some property left in Tweed-not much; a large lot in his son Dick; we find much in Sweeny and Smith. They do not seem to have transferred. The Watson compl. and sums. will be served in a day or two-to-morrow, if $\mathrm{Mr}$. O'Conor agrees to the draft I have.

"Yours truly,

"Winefler H. Peckilan."

\section{CILARLES O'CONOR TO TILINEN}

"Fort Washington, Friday, A pril 6th, 1875.

"DFar Sir,-Going on steadily with the proved narrative. It will soon be in a perfect condition. The revelations are most satisfactorily exact. The 'long train of abuses' will have an astomnding look.

"You are up to your eyes in a confusing multitude of affairs, and may not have as elear a vision as I fancy $I$ have concerning affairs here.

"There can be no doulth that, as usual in such alterations, there is a class who counted on coming into the succession and enjoying Tweed's privileges. In his day the so-called 


\section{I.ETTERS AND MEMORIALS OF SAMUEL J. TILIEN}

Demoeratic wire-pullers and the so-called Republican wirepullers understood each other and divided the spoils.

"This was a still existing policy at the last city election. Wales, the Republican candidate for Mayor, was nominated in the interest of the regular Democratic nominee, and ran to secure the defeat of Ottendorfer, who is an independent man, probably a very honest man and, for aught I know or suspect, would have as truly supported integrity and justice in government as anybody else. Accordingly, Wales, as appeared by the papers, was a champion of Bill Costigan.

"The hungry are fierce, and hardly know what to do with themselves or where to turn. They don't get a chance to turn Green out, and you keep the Corporation Counsel on his good behavior.

"It seems to me you must stick just as you are. I have not too much confidence in the most recently elected Democratic judges. I am sure that if the Mayor gets the making of a corporation counsel that office will become as bad as it ever was. Now the incumbent stands in dread, and behaves unobstructively. I write to advise that you beware how you alter this condition of things.

"You have gone so deeply into the hunt after scoundrelism that I do not see how you could repent, even if you wished to, and I presume you do not.

"One thing more. Special bills, etc., are being prepared and passed, too, in aid of jobs. If such things are to be helped or permitted to run through without opposition it surely will be idle to waste breath in pursuing Tweed.

"The public will sustain you in vetoing all these things. See the marked part of my opinion on constitutional amendments.

$$
\text { "Yours truly }
$$

\section{JOHN KELLY TO TILDEN}

\section{"Confidential.}

"New York, April 9th, 1875.

"MY dEAR Str,-The bill which was introduced yesterday by Miller, of Orange, has eaused a great deal of bad feeling here among our people. Green's connection with it is unquestionable. It is strange that any one claiming to 
be a Denocrat could act so unwisely. Such acts as these would destroy the best party organization in the country. I am astonished that our members could act so inconsistently. There is no apparent head in the Assembly, and in its present disorganized state its inconsiderate acts will tend to weaken us in the State and be the means of getting up an outside organization to co-operate with the Republicans next fall. Already this is being bruited abont now. I had expected that matters would proceed smoothly here in the future, and there would have been no diftienlty if discreet judgment had been used when this fiasco shall have subsided. I would advise that advances be made to the wellintending member's so that there may be entire unison of action. Above all, there must not be any disintegration among ourselves, except so far as they relate to corrupt nen, against whom we should set our faces.

"Your act in pardoning Ingersoll was severely eommented on at first. When your purpose wals explained the reaction was instantaneous; all now, or nearly all, commend you for it. The traitor is at all times despised, but treason is thonght well of, and particularly so when the people have obtained a substantial benefit, which will be, no doubt, the result in the Ring cases through the testimony of Ingersoll.

"Your steady and persistent course in these Ring frands will immortalize yourself, O'Conor, and those who have acted with you in the good work you have and are performing in the interest of the pepole. May God spare you and your assistants until you will have finished your tasks. Most of men would have become disheartened at the many repulses you have met.

"Now, my dear Governor, you must have a man in the corporation counsel's office who will act for the interest of the public. You cannot depend on the present incumbent in that office. If he were to act in good faith with you there still wonld be eavesdroppers about the concern who wonld carry the news outside; there must be an entire regeneration in that office to make it effective. Your time is now to follow up the present excitement incident to the release of Ingersoll. You will recollect how anxiously I pressed this matter on you when in Allany last week. Let me repeat to you again that you would be entirely safe in the hands of Whitney. He is an honest, high-toned gentle- 


\section{LETTERS AND MEMORIALS OF SAMUEL J. TILDEN}

man, and will eo-operate with you and do credit to himself. Don't let this matter pass over Saturday.

"I trust that you are enjoying" good health, and that your strength will hold out to enable you to add new laurels to your achievements.

"Yours truly,

"JoHN Kelly.

"To Samuel J. Tilden, Governor of the State of N. Y."

\section{CHARLES O'CONOR TO TILDEN}

"Fort Washington, Saturday Night, April 10, 1875.

"Denr Governor, - Mr. MeLean has just been here, and from him I gather that you are anxious for speed, and especially in re Sweeney.

"The more haste the less speed is often a true phrase. Everything necessary and within the limits of our power was done at onee to prevent 'Tweed's escape on a discharge likely to be awarded by his friends of the Refugium Pec. Other proceedings, it seemed to me, should be cantiously and deliberately initiated. I could not help seeing the judiciary's headway against us, and that the Scovil remedies bill, wounded and paralyzed in its birth, limps sadly. So in whatever I do I feel the necessity of eaution.

"I have requested Peckham and his allies to pick up the outside biographical facts concerning Sweeney and his tribe. How and when they went off, where they are, etc., etc. Whilst this is progressing I stay home and pump.

"The man is very intelligent; tanght by his sufferings, he is perfectly bidable and bent upon giving entire satisfaction. But men of his grade are bad at delivery, and need a midwife who has much industry and inexhaustible patience. He is in low health, constantly taking medicine, and it was not until Friday afternoon late that I got possession of him. The information comes forth very slowly, but I think in the most precise form. I got everything in the most painfully minute details; but it will not be painful reading. On the contrary, $I$ think it will be as amusing as instructive. I throw it all into narrative form. It will read like a novel; and although it is bad policy in general to show one's hand, I am under the impression that when I get through with him it would be a good operation to publish his narrative. 
"Sweeney is cumning in the extreme, and no donbt had the concealnent of his tracks in riew from the beginning. But it will surprise me if he ean eseape. I shall try to put things in such a shape that we can drop suddenly upon whatever may be here. I am told that he designed coming back to give his skilled talent to the task of defence. Between him and D. D. F. and the Refugium Pec. it might seem that a hopeful fight could be maintained for a little while. But there can be only one end.

"I think we will want an agent in Paris. I know one, Henry Harrisse, a lawyer there, who formerly perehed in this eity. Though a Frenchman by birth, he is perfectly conversant with our language, our people, and our affairs. I feel sure that lie is honest and trustworthy. Had I not best write to him at onee? The Sweeney tribe will probably have to be pursued to Europe. Tom Fields is there, and probably other subjects of discipline are or will be. IIad I not best write to Harrisse at once and retain him?

"You must be patient, no time is being wasted.

$$
\begin{aligned}
& \text { "Yours truly, } \\
& \text { "Charles O'Conor." }
\end{aligned}
$$

\section{WIIEELER IT. PECKHAM TO GOVERTOR TILDEN}

"April 1?th, $18 \% 5$.

" Mr dear Sir,--I had lis pendens filed on all the property Tweed has owned since 1867. Some little is still in his name. Nost of it is transferred. I have complete lists of the property of the Sweeneys and IIugh Smith, and lis pendens rearly to file the moment Mr. O'Conor gets the suits ready to begin.

"I saw him yesterday and forwarded to you his letter, which you received this moming, I suppose. I cannot hurry him. 'He is making the case as thorough and complete as possible. Ingersoll turns out to be all we expected, and is perfectly ready to do what he can.

"I don't think anything" can be lost by the few days' delay, as a transfer just now would be so clearly for purposes of frimel as to make it of [not?] the least benefit.

"I saw an article in the World to-rlay, copied from a Syracuse paper, to the effect that the Comrt of Appeals had come to a conclusion in the Tweed case and in his favor and on the points raised by Comstock. I don't believe it 
at all, but if so, it is most scandalous, as Comstock was allowed to raise his points in reply, and we had no opportunity to answer. There is nothing in his point as habeas corpus serving, and almost as clearly none as writ of error.

"If the court ever decided for Tweed it ought to be $d-d$ eternally.

"It scems to me almost impossible for it to do so honestly. "Yours truly,

"Wheeler H. Peckham."

W. C. BRYANT TO TILDEN

"New York, April 16, 1875.

"Denr Governor,-Julia has asked me to send you a copy of the contract between myself and Mr. Henderson in regard to the rent which is to be paid by the Evening Post in the new building. This is no contract, properly speaking, but only a letter from me to Henderson, in which our understanding respecting that matter is briefly stated. In the letter I simply say that I turn over the building to him, advise him to go on with it on his own account, making it convenient for the publication of a daily newspaper, and expressing my desire that a lease for twelve years of the necessary rooms shall be made to the Evening Post, "the rent to be fixed by two competent and disinterested persons.' This is all, and a copy of the letter would show nothing more.

"Yours faithfully,

"W. C. Bryant."

\section{CHARLES O'CONOR TO TILDEN}

"Fort Washington, Apl. 28, $18 \% 5$.

"Mr deAR Sir,-Our determination here is to push the Ring suits to decision as rapidly as possible. Once we get fairly started everything will move with the utmost rapidity. But getting the fair start is attended with no slight difficulty. The field is so wide and is so full of minute details, and the sonrces of information are so much more responsible than formerly. We must not let our deponents make any mistakes. Their knowledge being absolute and actual, their responsibility is great. If through haste or want of memory mistakes occur they may be pronounced 
wilful, and thus their credit be destroyed, or at least inpaired. By interlocutory motions, such as demands for impracticalile things, as copies of destroyed papers, etc., they will bring their judges down upon us, and thus precipitate the climax.

"Probably this is well enough. If their judges have resolution equal to their wishes they can defeat us, in despite of any lemislation. But it is to be hoped that fear, like the cackling of the Roman geese, may save the State.

"It is said that one of our X. Y. judges has pledged himself to save Sweeney. Very likely. And, I guess, whenever he has a chance, the Mayor will appoint as a corporation counsel a know friend of that alsent functionary.

" $\mathrm{My}$ precise motive in writing at this time is to warn you of the necessity of watching closely all amendments of the Code of Procedure, and any statutes coneerning praetice. There is great likelihood of an attempt to smuggle some bafter of that sort through the Legislature.

$$
\text { "Yrs., \&e., "Cir. O'Conon." }
$$

\section{WHEELER H. PECKHAM TO TILDEN}

\section{"Personal.}

" May 26th, 1875.

"MY DEAl Sir,-Yours of date 24th, postmarked 25th, is reed.

"In reply I have just written you at length, and looking at the length of the doement, have destroyed it, thinking that a long listory is not what you want.

"I had not seen the newspaper attacks or the eartoon; did not know that Barlow had a brother-in-law.

"You say that I may ascribe delay to Mr. O'Conor. I do. I drew and gave him complt. r's. Sweeney. I would have prepared affidavits. He assumed the duty of so doing himself. At his request I wrote you to pardon Ingersoll.

"Ile alone has seen Ingersoll, he proposing that it should be so.

"You say he is not above being helped and aided. I have been completely at his service from the moment he commenced till now. He has declined all assistance, saying that the drafting of affds., ete, was work at which but one 
could work. If there has been anything other or further that I conld do or could have done I do not know it.

"If the matter had bcen under my control I shd. have commenced suits and had attachments long before.

"They would have been without the perfect basis which the results of Mr. O'Conor's long labor will disclose.

"It may be that such perfect basis, when disclosed, will be well worth all the delay.

"Whether so or" not was and is for you and the Atty. Genl. to determine; not for me.

"After Mrr. O'Conor" assumed the labor of preparing the case vs. Sweeney, etc., it certainly would have been highly improper and indecorous for me to do otherwise than acquiesce. As to my personal action, all I can say is that I have been at his service always. That I have urged haste as strongly as common courtesy to him would allow. You speak of what might have been done 'if I had been really anxious to produce results.'

"I am at a loss to understand your meaning.

"You certainly cannot mean what the words apparently mean.

"I do not believe that there ever was a doubt in your mind, or the mind of any man, as to whether I was 'really anxious to produce results.'

"If there was you should not have employed me or suffered me to be employed. I have waited for Mr. O'Conor. Could I or should I have done otherwise? You say that Mr. O'Conor is above criticism. Agreed. But so far as anxiety to produce results - so far as devoting all time or labor to the cause, so far as making this business the very first, to the exclusion of everything else are concerned-I insist that $\mathrm{I}$ am as far above criticism as is Mr. O'Conor or any living man.

"If there is or has been any delay caused by want of zeal or attention on my part I shd. like to know it.

"You will note that I make no criticism on the delay in the preparation of the affds. I have not seen them, nor do I know what they will be. From the general description of them, given me by Mr. O'Conor, I think they will be well worth the delay, and when you come to know what he has done I think you will wonder not at the delay, but at how soon an immense work was accomplished.

"I only say in answer to your letter that the delay has 380 
been beyond my control. Mr. O'Conor yesterday expressed great confidence that he would have mamseript for me to begin printing by to-morrow or next day, and that I shd. have the aflils. for the use to oppose Tweed's motion for a bill of particulars Jume 1 st.

"From what he has said I suppose that when ready for our use they will be for all, and that we can commence the other snits next week.

"Whether the delay was wise or not is not the question.

"I only" say that whether wise or unwise I am not responsible for it, for I had not the power to control it. Responsibility goes with power.

$$
\begin{aligned}
& \text { "Yours truly, } \\
& \text { "Winkeler H. Peckilam. }
\end{aligned}
$$

"I will watch for eriticisms in the papers as to pardoning, etc., and see that any error is corrected.

"I rather think that the publication of the affds. Mr. O'Conor is preparing will be the best answer that ean be made to eriticisms, and I now feel quite hopeful that they will be ready next week."

\section{CIIARLES O'CONOR TO TILDEN}

" Fort Wasmington, June 1,th, 1875.

"Mr dear Governor,- - Herewith you will receive a fair copy of the views which strike me as just in respect to the leases.

"There does not seem any need of occupying your time with a call. Your allowance for this task of passing on the bills is so near its close that every intrusion, however slight in duration, must be an evil.

"But a single thing ocenrs to me in your aid.

"Where you camnot approve a bill, is not a simple withholding of your signature the true conrse?

"Such appears very clearly to me to be the proper course. A written memorandum of the reasons which governed you might be nseful, and, if time admitted, should always be made; but a formal veto does not seem to be ealled for or expedient. It must necessarily wear an aspect of severity. A purely negative course is less offensive.

$$
\text { "Yours truly, }
$$


DANIEL MANNING TO TILDEN

" Office of 'The Argus,'

"4l2 Broadway, and 2, 4, 6, ANd 8 Beaver St.,

“Albany, June 20, $18 \% 5$.

"Dear Governor,- Since you, following in the wake of the Legislature, abandoned the capital, Albany has been extremely slow and stupid; but the coustant and voluminous gossip that has prevailed regarding the supply bill indicates that, although absent, you are very "numeronsly remembered,' and, no doubt, prayed for. Will all the prayers be continued after the thirty days have expired? I am not sure, if I were near you, that I should ask you to approve the new capitol item. As an Albanian, perhaps yes; as a citizen of the State, possibly no; and as a Democrat, no, most decidedly, without a change in the management.

"Your arguments on the canal appropriation bills are really admirable-so strong, elear, and convincing, indicating so much research and such thorough knowledge of the whole intricate subject. They will be very popular, even beyond the State; and here no voice will venture to rise in opposition.

"The malcontents are restless, vituperative, mischievous, and cowardly. They abound in threats and slurs and insinuations, and would do much harm if they only dared and knew how. But they are bewildered, and so simply stand under cover, make faces, and tell what they intend to do at the next State convention; among other things, they. are then and there to annihilate the Argus. Our organization here, with Abraham Lansing for president, is very strong-stronger than ever before-and we shall send an influential and a united delegation to the convention. The soreheads begin to count much upon the ripple of disagreement that seems to exist among our friends in $\mathrm{N}$. York. The Governor must smooth the troubled waters. He knows how.

"Return to Albany as soon as you can. Diluted as they. are, can't the principles of the removal bill be applied to those Job's comforters with some effect?

"Respectfully and truly yours, "Daniel Manning." 
TILDEN 'TO FRANCIS S. THAYER, AUNTOR OF CANAL BOARD

"Personal.

"New York, June 25th, 1875.

"MY IDar Sir,-You are quite eorrect in assmming that no action of mine on any bill or iten has been inspired by anything but kindly disposition towads you.

" 1 . The canal extraordinary repair bill. When I found that I must reto this I at once communicated with you, and expressed the opinion that it would not prejudice your position as to the $\$ 15,000$. That is my opinion now. I do not see any reason to doubt that you can pay that sum ont of ordinary repairs. 'Tho' as an original job it may have been extraordinary work, when it cane to be left in a condition to interfere with the enrrent use of the canal, the removing of the obstruction, and putting in order the bank of the canal, is ordinary repairs.

"You may get the money at once on this theory. You could not get it under the extraordinary repair bill.

"2. The ITndson River improvement bill. The Comptroller informed me that there would be no money to pay for this object or the soldiers of 1812 . The veto certainly had no reference to the commissioners.

"3. The supply bill was finally disposed of on information that had gradnally been collected in the last two days of the period allowed by the Constitution, and while $I$ was disabled by boils, so that I could not sit up. I should have conmunieated with yon abont the item of $\$ 750$ if there had been time. I supposed I had suflicient and correct information from a gentlenan to whom I had referred a portion of the supply bill for the investigation of facts.

" Ilis report to ne was that this item was in conflictby inadvertence, I presumed - with two clauses of the amendunent to the Constitution.

"Certainly I had no idea of mukindness or disrespect towards you. I shall be lappy to look into the case, and if there is power to malke this provision, to favor it.

" I have on several oecasions manifested farorable sentiments towards you and your brother. I mentioned him favorably in the special canal message, and you on some recent occasions.

"I gave up my judgment as to the $\$ 150,000$ for tho aqueducts and 16 locks to your joint opinion and wishes. 383 
"I desire to treat you with consideration, and to cooperate with you for the public good.

"Of course I have defined views of duty in respect to the policy to be pursued as to the canals, in which I should be glad to have your concurrence as far as is consistent with your judgment.

"I have dictated this hasty answer to your note in order to avoid delay.

"Hon. Francis S. Thayer."

FRANKLIN B. DEXTER TO MR. TILDEN

(MR. TILDEN RECEIVES THE DEGREE OF LL.D. FROM HIS ALMA MATEF)

"Yale College, New Haven, Conn., July 5, 1875.

Srr,-I have the honor to inform you in an official way that the president and fellows of this college, at the recent public commencement, conferred upon you the honorary degree of Doctor of Laws, and in comnection with that act enrolled you with the academical graduates of the college in the class of 1837.

"In thus recognizing the eminent public services which have so abundantly deserved the honorable regard of all public-spirited men, the corporation arc especially proud to recall the fact that the foundations of your educational training were in part laid here, and to claim you, in virtue of this former connection, as an alumnus of Yale.

"Very respectfully, "Your obedient servant, "Frankilin B. Dexter, "Secretary.

"His Excellency Gov. Tilden."

ChARLES O'CONOR TO S. J. TILDEN

“ City of' New Yonk, Station M, Aug. 12th, 1875.

"DEAr Sir,-So the anti-peculation campaign is fairly opened. It can eventuate on one way only. No such controversy ever ended in favor of the swindlers.

"But you want some documents. A big one is being prepared by a sub-editor licre. He asks me for some facts. 384 
More than I can give him. Will you make some of your troops get for me:

"1. Copy of the minutes of the proecedings of a little extemporaneous bar meeting in Albany, held during the 'Tweed lab. corp. argt. G. T. — in the chair. I). I). Field moved. I never saw them. T think they must be in the Argus. Let us have nume and dale of the paper. It relates to a new form of obsequious reverence for appeal judges.

“2. The letter of Allen J., just previous to your nomination, offering to withdraw, if every one else would, in favor of his cousin Church. Name and dale of paper.

"I want you to give me the pedigree or connecting link by which Allen's commsinship to Church appears. Mistakes will oceur unless nen are careful. If you don't know the connecting link, how ean it be relied npon? Don't you know the principal fact?

"In looking into the history of the men, I am most at a loss to account for Grover's fall. I lave a theory, but it is not as clear and satisfactory as the known facts in respect to all other's.

"Your speeches make the welkin ring. Why did you not touch them up at Rochester? Is there a strong peeulation clique there? 'Begad, I hegin soospec,' as the Frenchman said when he caught a man in bed with his wife.

"I wish very much I could have a little chat with you, but I suppose it is impossible.

"I want a short, succinct statement of the canal frauds detected by the recent committee. I don't know how to draw it myself. I mean what I say, a "short and succinct" thing.

"The anti-peculation document in contenplation will go hopping along on one leg if there be not a better slort presentment of the canal detection than any one here knows how to write.

$$
\text { "Y'rs truly, "CH. O'Conor. }
$$

"P. S.-Answer as quickly as you can."

On the 9th of August, 1875, E. Delafield Smith was renzoved from the office of eomsel to the corporation on charges formulated by Charles O'Conor, the sufficiency of 
which was approved by Governor Tilden in a letter which follows. On the same day the late William C. Whitney was appointed to the office raeated by Mr. Smith. Mr. Whitney, at the time of his appointment, was but thirtysix years of age.

“State of New York, Executive Cilamber, "To the Hon. WM. H. Wickinam,

"Albany, August 6, 1875.

Mayor of the City of New York.

"Sir,-At the time the proecedings for the removal of E. Delafield Smith, counsel to the corporation of the city of New York, matured in the submission to me of all the papers which either party deemed necessary to a full hearing of the ease, the bill under which the suits growing out of municipal frauds were transferred to the care of the Attorney-General was well advaneed towards its passage, and scon after it became a law.

"So far as any urgeney resulted from the connection of this case with those suits, that element disappeared; and in no other respect were the interests of good government in immediate jeopardy. In the mean time the absorbing demands of measures of canal reform, and the pressure of legislative business superseded all less urgent matters; and in accordance with the usual practice of the executive office, this case, with similar ones from other parts of the State, and with the mass of kindred business, was deferred until after the close of the legislative session, and after the action on the bills and appropriations left at the adjourmment, I have now examined the voluminous papers submitted, and have carefully considered the facts and evidence which they present, with the aid of such other light as was within my power.

"I am of the opinion that acts are established which amount to causes of the nature contemplated by law, and which would at least be sufficient to induce a private client to change his comsel. It seems to me quite clear that a rule at least as stringent as would govern a private client ought to be applied for the protection of a great conmmuity besieged by many millions of unjust and fraudulein claims, which are prosecuted with the energy of private interests, and which are always able to obtain great advantages over 
the public in a contest of professional talent, skill, zeal, activity, and persistence. I have, therefore, exeented a certificate of apploval, which is herewith transmitted. I have the honor to be your obedient servant,

"Shalee. J. Thliden."

\section{Cilarlats o'Coxor to TILDEN}

"Fort Wasuingtox, Sicpt. 30, 1875.

"De.n Sir,-The thing I apprehended, when suggesting doubts as to the expediency of removing Smith, begins to develop itself.

"All outside comnel, i. c., Barlow, Carter, and the like, are heneeforth to be excluded from any eity defence against jobbery. The new eorp. counsel and his elerks and employés inside of the office are to conduct all the city's business.

"The earliest fruit of this will doubtless be the recovery of $\$ 100,000,000$ against the eity in the water-meter case. This was one of 'Tweed's last contracts. Plenty more of like sort will follow.

"Browne's* article cannot be got into any of the city papers. Many conjectures as to the cause might be indulged in. But one is that, it being very long and requiring an extra for its publication, the printers think the reformers ought to be paid for.

"I know no one who is able and willing to contribute to the cost, and I am not inclined to incur additional expenditures whilst standing alone in that department.

"Your's truly,

"Gov. Tilden."

“CiI. O’Conor.

IORATIO SEYMOUR TO GOVERNOR TILDEN

“UTica, October 19, 1875.

"MY dear Sir,-T am ton ill and too old to do mueh at this clection. $t$ I have been kept in my house for somo days by sickness. I shall be glad to help all I can, as I do not

* Presumably then managing editor of the Evening Post.

t leferring to the approaching alection of State ofleers, at which the Governor:s canal reform policy was to be submitted for the first lime to the popular crucible. 
like the looks of the eanrass. I fear the loss of some part, if not of the whole, of our ticket or of a majority so small that it will be comnted a defeat. My fears may spring from the distrust which old men have of the future. Do not feel too sure. I know you are very confident, and so are the Republieans.

"To Governor Tilden.

"I am, truly yours, \&c.,

"Horatio Seymour.

"I will let you know what I ean do."

\section{J. E. COOLEY TO TILDEN}

"Palazzo Cooler, 2 Via dei Pucci,

"Flonence, Italy, Oct. 20th, 1875.

" Hon. Samuel J. Tilden.

"Denr Sir,-Allow me to congratulate you on the sueeess and popularity of your administration as Governor of the State of New York. It seems to have the true Bentonian and Silas Wright tone or ring in it. I like it, and wish you the most perfeet and entire suceess in the noble and patriotie efforts you are making to ferret out and punish thieves, without regard to party, and bring back the administration of the public affairs in the State of New York to the splendid condition they were in when eonfided to the guidance and eare of such men as Wright, Marey, and others of their best and most influential days. May God give you health and strength to earry out your noble purposes to the ntmost limit of your eommendable aspirations.

"I rejoice to hear of the signal defeat of the Democratie party of Ohio on their shameful inflation platform; and I am prayerfully hopeful that a similar result may aecrue to the silly, not to say dishonest, inflationists of Pennsylvania. However mueh it may be regretted that the foolish inflationists of the Demoeratic party should have had sufficient influence to insure its defeat this fall in those two States, it will have the good effect to tumble out of the Presidential path several aspirants and possible candidates for that high office.

"The Demoerats in the United States have once more the political eards in their own hands, and they are mostly 
trumps. Two-thirds, I may venture to say, of the Republican party, are weariod, not to say disgusted, with Grant's administration and sigh for a change, which wonld have been affected at the last Presidential election hut for the ineonceivable folly of the Denocratic party in noninating Greeley, who for forty years had exerted limself to the utmost of his ability to destroy the party and malign and blacken the character of the most pure-minded and patriotic menbers of it.

" Free trade, reform, and speedy return to specie payments' should be the conspienous iallying or watehwords of the Demoeratic party in the future; and it must follow, as the night the day, that, with that insignia inseribed upon its banners, and witlo candiclates truly representing the sentiment or policy it indicates, the party will next year triumphantly sweep the country from one extrenity to the other.

"Protective duties, Civil War, and exeessive issues of paper money have done much to demoralize the eharacter of our people and waft the eomtry towards the brink of ruin! It is high time to loring these destructive measures to an end; and to the Demoeratic party, rightly direeted, is reserved the noble and patriotic mission of effecting this incalenlable benefit to the United States, which would bring back the party itself to the enjoyment of all of its pristine power and the warm affection of an werwhelming majority of the people.

"The war is happily at an end, and protective duties may be abolished by repealing the rumous acts that anthorize their mjust exactions. But a return to specie payments camot be effected by simply passing resolntions or empty and vague enactuents of Congress. Soncthing more grave and important is repuired to insure this great and muchneeded reform in the deplorable financial combition of the country.

"In an extremity, and as a war measure, the government, having undertaken to furnish a paper eurrency declaned to be equal in value to gold; and having made that enrrency the basis of a system of banking, which has been generally adopted throughout the comntry, it cammot now withdraw itself from the full responsibility of that position without great detriment to the best interests of the eomintry, and ineuring lasting dishonor, until it shall have, as it is abnu- 
dantly able to do, appreciated that currency and brought it up to par in gold. This being done, the government will hare returned to specie payments; and greenbacks, being the basis of banking, the banks themselves will also have resumed specie payments, if in a solvent condition, with an angmented appreciation of the whole volume of the currency, including the greenbacks and the bills of the national banks equal to the difference between the current value of the depreciated currency and the price of gold in the American market, which I perceive by the last quotations is $\mathbf{1 6}$ per cent. This agio or premimm, calculated on the whole amount of paper currency now issued by the national banks and the govermment (equal, I suppose, to no less than $\$ 700,000,000)$, would amount to $\$ 112,000,000$; and this large sum is simply what would, in that event, justly accrue to the possessors or holders of the depreciated currency of the govermment and the national banks.

"How, it may be asked, can this desirable result be easily attained? Evidently in no other way than by the government taking such steps and adopting such measures as will surely bring into its possession an amount of gold sufficient to enable it to deal in its own currency for all government transactions. How is this to be done? Simply by a six-per-cent. ' redemption loan,' having 30 years to run, and to an amount equal to the full volume of the greenback currency now afloat. I say six per cent. because I would make the absorption of the loan speedy and sure, though it is not unlikely that a loan of the kind might be slowly negotiated at 5 or even $41 / 2$ per cent. interest. But a government loan at 6 per cent., having thirty or even twenty years to run, wonld be caught up with avidity by capitalists on both sides of the Atlantic at a large premium; and it would at once throw the balance of trade in favor of the United States, so that there would be no immediate demand for gold abroad. It would, also, break down at once the mischievous ring speculations in gold at home, and obviate the necessity of buying gold for the payment of customs; and as gold could be obtained at any time for greenbacks or the bills of specie-paying banks, the demand for it would become so small that gold, instead of commanding, as it does at present, a ruinously high premium, wonld most likely become a drug!

"Such a loan as I have indicated should be put upon the 390 
principal money markets of the United States and in Enrope and bid for simultaneously, and payable in gold.

"Should such a condition of monetary affairs be attained the govermment might withllaw the greenbacks from circulation, so fast as the volume of enrency necessary to meet the requirements of commeree should be supplied by sound specie-paying banks, mntil the whole amomut $(\$ 400,000,000)$ shall have been retired, without disturbing materially the general eurrent of trade or adding a single dollar to the present indebtedness of the United States. The interest on the new loan would, of course, have to be provided for; but that would be more than compensated by the saving of gold promimn, now annually required in payments for foreign importations, which, whatever may he the amount, is adled to the price or cost of all foreign commodities consmmed by the people of the United States. The loan, moreover, would doubtless be taken at a premium of 10 to 15 per cent.; if so, $\$ 40,000,000$ to $\$ 60,000,000$ would be realized by the government by the operation.

"The glory of this great and patriotic achievement may be made to redound to the lonor of the Demoeratic party is aroused to a proper sense of justice, and stimulated to a faithful performance of its obvious duty to the country; and, above all, inspired with a firm determination to be true to its own self.

"I have the honor to remain, with great respect, "Very truly, your friend, "J. E. Cooley."

\section{DAVID A. WELLS TO TILDEN}

“Norwicin, Covs., Nov. 9th, (1875).

" Mr DEsR Mr. Tilnex,-I return herewith answers to all your list of questions, so far as $I$ :m able. It is not easy to give definite answers to all, especially in relation to aggregate national wealth, income, and savings.

"I do not believe it judicions for you, in your message, to enter in any degree into the field of economic eontroversy. The mases won't eomprehend, and the doctrinaires will fight you. Stick to the great principles, and to not commit yourself against eontraction. T have thonght a good deal over our conversation of last week, and I am more and more convinced there is no other practical way out of our financial 
difficulties. 'All roads lead to Rome,' and all roads to resumption involve contraction at some stage if they lead where they pretend to.

$$
\begin{aligned}
& \text { "Very Truly Yours, } \\
& \text { "David A. WeLls. } \\
& \text { " Questions }
\end{aligned}
$$

"، 1. What, at a given period, was the population of England, France, United States?

" 2 . What is the best estimate of their aggregate capital at such period?

" 3 . Their annual gross income or earnings?

"4. Their annual income from foreign government? debts?

" "5. Their annual outgo to pay interest on foreign

" 6. Their annual net savings or accumulation?

" 7 . Their exports?

"imports?

" ، 8. Production of gold and silver in United States for each of five years?

" ' Exports and imports of gold and silver during same period?'

\section{" ANSWERS TO QUESTIONS.}

"No. 1. Population.

From 1872. France (exclusive of Alsace and Lorraine) . . . 36,102,920

" " Great Britain ......................,

“ 1870. United States (Census)........................ 115,641

" 1872. " " (Estimated) $\ldots \ldots \ldots \ldots \ldots \ldots \ldots . \ldots \ldots, 000,000$

\section{"No. 2. Aggregate Capital.}

"United States.-The valuation of the property of the U. S. by the census of 1870 was (in currency) $\$ 30,068$,000,000 . The returned assessed valuation for the same year was less than one-half, or $\$ 14,178,000,000$. The census counted as property, both property and the evidence of debt secured on such property. I do not think the productive capital of the United States in excess of $\$ 25,000,000,000$.

"Great Britain.-Baxter, in 1867-8, estimated, from accepted data, the aggregate value of the real and personal property of the United Kingdom at 6,000,000,000 pounds, 
or $30,000,000,000$ dollars. I should put it for 1872 as high as seven, possibly cight, thomsand million poumds.

"France-I know of no estinate of the aggregate value of property in France. I find several recent French writers, who incidentally refer to it, as less than that of Great Britain.

\section{"No. 3 ANd 5. Axnull Gross and Net Income on Savings.}

"Baxter estimates, for 1867-s, the annul gross income of the United Kingdom as $\$ 14,000,000$, or $\$ 4,070,000,000$; and the net at about $600,000,000$, or $\$:, 000,000,000$. 'This last constitutes the fund ont of which the nation feeds and clothes itself, pays taxes, and repairs and saves. I should estimate the gross income of Great Britain for 1S72-4 at full 1,000,000,000, and the net at $800,000,000$. There are no reliable data for estimating ammal savings, constituting new capital. Ten per cent., which is a high estimate, in my judgment, would give $\$ 0,000,000$, or $\$ 400,000,000$; and yet these figures are not eonsistent with the recent retums of the Board of Trade, respecting the ineone from British foreign investments.

"France.-Victor Bonnet asserts that the data are certain that France before the war of 1870 sared amnally as much as $\$ 400,000,000-2,000,000,000$ franes; and thinks that the present saving is about $\$ 600,000,000$. TTe quotes Sir Robert Peel, approvingly, to the effect that France, with equal revenues, saves more than Great Britain.

"United Slales.-Greater natural resourees liere give a greater gross and net income, with equal labor. I :m inclined to put our gross incone between $\$ 6$ and $\$ 7,000$, 000,000 . I do not helieve our ammal saving, in prosperous years, in excess of five per cent., or from $\$ 300$ to $\$ 400$,000,000 .

\section{"4. Annual Income mom Foreign Investments.}

"Great Britain.-A late number of the London Economist puts $80,000,000, \cdot 0 r^{\circ} \$ 400,000,000$, at the minimum paid Great Britain by foreign comntrices for interest on capital inrested abroad, and for freights and commissions. The last year, I should think, represented full one-lhird. 


\section{LETTERS AND MEMORIALS OF SAMUEL J. TILDEN}

"France.-The estimate of revenue derived by France from industrial enterprises in foreign countries and foreign loans, from $1873-4$, is about $260,000,000$ franes, $\$ 52$,000,000 .

"United States.-Nothing.

"5. Annual Outgo to pay Interest on Foreign Derts.

"Great Britain.-Nothing.

"France.-An inconsiderable amount, probably not in excess of 12 to 15 millions of dollars.

"United States.-Not less than one hundred millions of dollars. Probably more than less.

\section{"7. Exports and Imports.}

United States... 1872-3...Exports... \$677,000,000, Currency.

$$
\begin{aligned}
& \text {...1873-4 . . . " . . . } 716,000,000 \text {, } 649,000,000 \text {, Gold } \\
& \text {...1872-3 . ...1mports... 6 649,000,000, Gold. }
\end{aligned}
$$

Great Britain . . . 1872-3 . ...Exports. . . £311,000,000, $\$ 1,555,000,000$ $\ldots 1873-4 \ldots$ " $\ldots .297,000,000$, or $1,985,000,000$

....1872-3 . ...Imports... . 371,000,000

...1873-4... " ... $370,000,000$

Franee..........1872. ....Exports . $\$ 3,679,000,000$ franes, $\$ 735,000,000$ ....Imports . . 3,447,000,000 franes, $\$ 689,000,000$

"S. Bullion Product of tite United States for eacil of Five Years.

"The present product of gold and silver, or rather the product for 1873 and 1874 , is estimated by the director of the Mint in his last report at $\$ 70,000,000$ per annum. For the five years, from 1871 to 1876 inclusive, an average of $\$ 60,000,000$ per annum would probably be about eorrect.

“9. Exports of Gold and Bullion for Four Years.

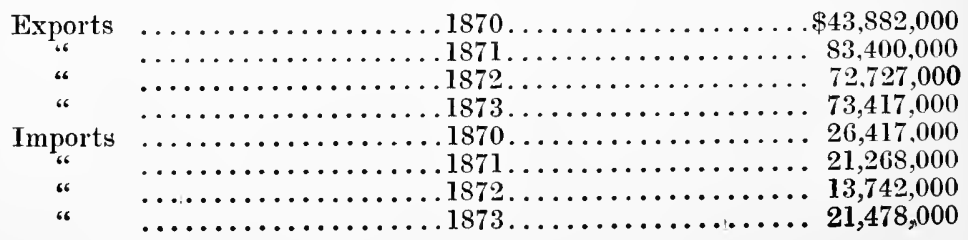

[END OF VOLUME I.] 


\section{.}




\section{.}

. 

